Routledge Research in Character and Virtue Education

\title{
A CHRISTIAN EDUCATION IN THE VIRTUES
}

CHARACTER FORMATION AND HUMAN FLOURISHING

\author{
James Arthur
}


'A must-read game-changer for all who seek human flourishing.' Professor Mark Pike, Principal Investigator of 'Narnian Virtues' 


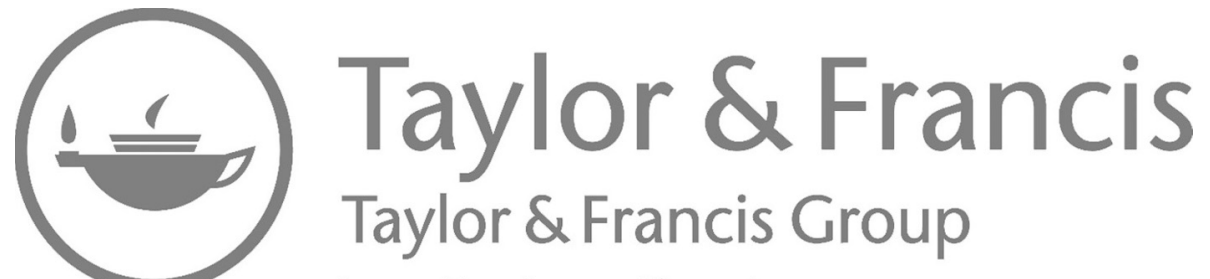
http://taylorandfrancis.com 


\section{A Christian Education in the Virtues}

A Christian Education in the Virtues examines the connection between human nature and human flourishing. It draws on ancient and medieval sources to explore the formation of the person based on a Christian anthropology, emphasising the communal nature of the virtuous life, and provides a richer approach to the question of contemporary character education.

The book argues that the only way to understand and construct our character virtues is to have a clear picture of what is the purpose and meaning of human life. It highlights the importance of engaging with moral issues and makes the case that, for Christian educators, human flourishing is inseparable from God's active relationship to human beings. The book also explores a teleological approach to character education goals. To educate the whole person in the light of an all-embracing Christian worldview is challenged by secular and liberal ideology and is often seen as irrational to the modern mind. Overall, the text seeks to demonstrate that many aspects of a Neo-Aristotelian-Thomist theoretical underpinning for Christian character education holds out a viable option for Christians. It therefore argues the case for the educational potential of Christian character education.

This important book will be essential reading for academics, researchers and students in the fields of character and virtue education, religious education and the philosophy of education.

James Arthur is Professor of Education and Director of the Jubilee Centre for Character and Virtues at the University of Birmingham, UK. He is the author of numerous books relating to character education. 
Routledge Research in Character and Virtue Education

This series provides a forum for established and emerging scholars to discuss the latest debates, research and theory relating to virtue education, character education and value education.

The Theory and Practice of Virtue Education

Tom Harrison and David Walker

Cultivating Moral Character and Virtue in Professional Practice David Carr

Virtues in the Public Sphere

Citizenship, Civic Friendship and Duty

James Arthur

Virtues and Virtue Education in Theory and Practice

Are Virtues Local or Universal?

Catherine A. Darnell and Kristján Kristjánsson

A Christian Education in the Virtues

Character Formation and Human Flourishing

James Arthur 


\section{A Christian Education in the Virtues}

Character Formation and Human

Flourishing

James Arthur

Routledge
(2)
Taylor \& Francis Group
LONDON AND NEW YORK 
First published 2021

by Routledge

2 Park Square, Milton Park, Abingdon, Oxon OXI4 4RN

and by Routledge

605 Third Avenue, New York, NY 10017

Routledge is an imprint of the Taylor \& Francis Group, an informa business

(C) 2021 James Arthur

The right of James Arthur to be identified as author of this work has been asserted by him in accordance with sections 77 and 78 of the Copyright, Designs and Patents Act 1988.

Trademark notice: Product or corporate names may be trademarks or registered trademarks, and are used only for identification and explanation without intent to infringe.

The Open Access version of this book, available at www.taylorfrancis.com, has been made available under a Creative Commons Attribution-Non Commercial-No Derivatives 4.0 license.

British Library Cataloguing in Publication Data

A catalogue record for this book is available from the British Library

Library of Congress Cataloging-in-Publication Data

Names: Arthur, James, 1957- author.

Title: A Christian education in the virtues : character formation and human flourishing / James Arthur.

Description: Abingdon, Oxon ; New York, NY : Routledge, 202I. |

Series: Routledge research in character and virtue education | Includes

bibliographical references and index. |

Identifiers: LCCN 2021005407 | ISBN 9780367694548 (hbk) |

ISBN 9780367694555 (pbk) | ISBN 978I003I 4 I 877 (ebk)

Subjects: LCSH: Character-Religious aspects-Christianity. | Virtues. | Virtue.

Classification: LCC BV4599.5.C45 A78 202I | DDC 241/.4-dc23

LC record available at https://lccn.loc.gov/2021005407

ISBN: 978-0-367-69454-8 (hbk)

ISBN: 978-0-367-69455-5 (pbk)

ISBN: 978-I-003-I4I87-7 (ebk)

DOI: $10.4324 / 978|003| 4 \mid 877$ 


\section{Contents}

Acknowledgements

Foreword

$\mathrm{x}$

Introduction

xiii

1 Character formation and theological challenges 1

2 Christian anthropology and Aristotle's character ethics 23

3 Thomism and Christian moral character 47

4 Christian character and pedagogical virtue education 84

5 Integral human development and Christian character education 113

6 A theological framework for character formation 138

$\begin{array}{ll}\text { Conclusion } & 154\end{array}$

$\begin{array}{lr}\text { References } & 160\end{array}$

$\begin{array}{ll}\text { Index } & 172\end{array}$ 
'But because many take more pains to be learned than to live good lives, therefore they often go astray, and bear no fruit at all, or but a little.'

Thomas À Kempis, De Imitatione Christi I.3 


\section{Acknowledgements}

A number of people have given me great help in the preparation of this book, have read it and offered comments and corrections. Benjamin Miller and Rachael Hunter generously discussed this book project with me at the start and encouraged me in the directions I took. I want to thank Aidan Thompson and Matthew Collins from the Jubilee Centre for Character and Virtues at the University of Birmingham for proofreading the text and offering suggestions that improved the clarity of the writing. I would like to thank Professor Kristján Kristjánsson, Professor Trever Cooling, Professor John Haldane, Professor Christian Miller, Professor Gerald Grace and the Rev. Dr Ezra Sullivan OP, who were generous with their time and help in reading and commenting on some chapters of the manuscript. In particular, I cannot thank the Rev. Professor Simon Gaine OP enough for offering extremely useful guidance on the text during my curtailed sabbatical at the Angelicum University in Rome in the autumn of 2020. I am also most indebted to my good friend Professor Candace Vogler of the University of Chicago for agreeing to write the short foreword to this book - I am forever grateful. 


\section{Foreword}

\section{Of Christian education in a secular age}

James Arthur's account of Christian Character Education is, in the broadest sense, integrative. Long famous for his leadership of the Jubilee Centre for Character and Virtues, overseeing the Framework for Character Education developed through their research over the past decade. In this book, he both draws from the Centre's experience and finds a proper home for the Centre's work in the context of broadly Thomist practical philosophy, theology and anthropology. To that extent, Arthur's new book baptises secular work on character education - his ThomistAristotelianism finds the underlying principle of unity that aims to help students become more fully actualised good human beings, leading meaningful lives with clear senses of purpose oriented to life together in Christian community, carried forward into circumstances that are not explicitly shaped by faith.

To this end, he takes the reader on a journey that begins in the profound challenges facing Christian educators in a secular culture that tends to view education largely in terms of standardised measures of academic attainment, the need for students to develop, clarify and find ways of expressing personal values, and, ultimately, the demands of professionalisation or vocational training that will help them lead materially secure lives. As Arthur points out, not even resolutely secular theorists of character or education think that the aims of education have been fully achieved if students graduate with high marks, some way of expressing what they think matters in life, and reasonable job prospects. If they are fortunate enough to find themselves leading relatively comfortable, settled lives, there's very little to prevent them from finding themselves in a situation very like the one that confronted John Stuart Mill in his twenties:

I was accustomed to felicitate myself on the certainty of a happy life which I enjoyed, through placing my happiness in something durable and distant, in which some progress might always be making, while it could never be exhausted by complete attainment. This did very well for several years .... But the time came when I awakened from this as from a dream. It was in the autumn of 1826. I was in a dull state of nerves, such as everybody is occasionally liable to; unsusceptible to enjoyment or pleasurable excitement; one of those 
moods when what is pleasure at other times becomes insipid or indifferent .... In this frame of mind it occurred to me to put the question directly to myself: 'Suppose that all your objects in life were realized; that all the changes in institutions and opinions which you are looking forward to could be completely effected at this very instant: would this be a great joy and happiness to you?' And an irrepressible self-consciousness distinctly answered, 'No!' At this my heart sank within me: the whole foundation on which my life was constructed fell down. All my happiness was to have been found in the continual pursuit of this end. The end had ceased to charm, and how could there ever again be any interest in the means?

(Mill, 1981: 137, 139)

The means-ends instrumental tone of Mill's lament is in keeping with the instrumental understanding of the aims of education. In his twenties, of course, Mill had all of those things that contemporary secular accounts of the aims of education seek to inculcate in students - an excellent background in arts and sciences, a solid professional post, tremendous outlets for self-expression, a developed and articulate view about what matters in life, and even a coordinated character that featured many of the kinds of strengths and dispositions that contemporary secular theorists of character and character education applaud. He had tremendous powers of concentration, perseverance, a finely trained intellect and a disciplined, strong imagination. He was civic-minded, eloquent, quick and steady. He was honest, humble and appropriately grateful. The problem was that none of it was adequate to the task of providing him with a meaningful life. In this sense his experience can serve as a powerful object lesson in both the strengths and limitations of an excellent, secular, character-focused education.

What, then, was missing?

On Arthur's account, what was missing was precisely the kind of unity and direction that we can find if our understanding of the aims of education emerges in the context of faith, and the profound integration of spiritual, intellectual, emotional and volitional life that we gain when we re-articulate our understanding of education in light of our theologically informed account of the human person.

To flesh this out, Arthur discusses both the nature of the human person and our efforts to grow into the sort of people we can be in the life of Christian community. Drawing from Aquinas and more recent neo-Aristotelian sources, he develops a clear and remarkably straightforward account of what education most properly is, and of what education most properly aspires to do.

In the course of this work, he provides a very helpful history of the varieties of Thomism that served as resources for re-thinking Catholic education in the twentieth century, drawing from a wide variety of sources. He casts a helpful critical eye on models of Catholic education that emphasised dogma and rules at the expense of attention to character-formation; an emphasis, he argues, that may have distorted students' engagement in the sacramental life of the Church. God's love, the salvific sacrifice of Christ, and the work of the Holy Spirit as 
these are embodied in the lives of Christians (rather than lists of sins and standard forms of penance) provide the life-force of Christian education. The trouble about sin is that it interferes with our relation to God.

He brings us to the current moment by giving the reader grounding in the concrete work of on character education many of us may have met in our acquaintance with the Jubilee Centre's efforts. This work is by far and away the most detailed and readily accessible work on character education that one can hope to find in contemporary education theory and practice. The Jubilee Centre provides educators with a wealth of material that they can access and use in their efforts to integrate character into primary and secondary education. Most recently, the Centre research teams have developed a new model of practical wisdom as a way to draw together work on intellectual, moral, civic and performance virtues, which might otherwise appear to be a system of isolated strengths lacking a strong core. Arthur, instead, draws from Aquinas's work on the cardinal virtues to provide a theologically informed outline of what the many and various strengths might have in common, and how they might best be seen as integral aspects of a good character. On this view, if I understand him, the unity of the virtues is just the unity of the human person, created in the image of God, living a life of faith, learning and growing in human community. The missing ingredient in John Stuart Mill's otherwise splendid education turns out to be the ingredient in light of which the whole effort of education makes sense.

Arthur's account is both useful and a spur to further reflection and discussion. The narrative is clear and compelling. Each chapter concludes with a series of questions that both orient the reader and give us occasions to move forward in our thinking about Christian education. Throughout, we have the pleasure of Arthur's distinctive voice, the testament to his own faith, and his wide-ranging erudition and experience.

Professor Candace Vogler

David B. and Clara E. Stern Professor of Philosophy University of Chicago 


\section{Introduction}

In many ways, this book is a new departure for me. Directing the Jubilee Centre for Character and Virtues over the last ten years has taught me that Aristotle (384-322 $\mathrm{BC})$, despite his undoubted deficiencies, offers teachers, parents and the wider community renewed hope and purpose in educating for character in the twenty-first century. This is even more remarkable considering the ancient Greek origins of his ethical ideas on how we may seek to flourish as human beings. Through him, the Jubilee Centre has helped bring some of the best ideas of the past into the present and has seen them increasingly and successfully embedded in schools, charities and businesses for working towards living just and happy lives. A neo-Aristotelian approach to character development encourages people to become wise, just and self-controlled by intelligently practising the virtues that constitute their character. At the same time, we in the Jubilee Centre have found that Aristotelian ideas have the potential to promote inclusion, social justice and civic democracy. From the viewpoint of neo-Aristotelianism, there are multiple perspectives on character that emerge, but far from being mutually exclusive, they are often intertwined and interdependent. However, Sanford (2015: 256) claims that the variety of neo-Aristotelian approaches that have emerged in ethics is only thinly Aristotelian. Despite this claim, I believe that these perspectives have collectively reintroduced some of the perennial questions about how we should live our lives.

I have been personally thinking and writing about character education for more than 25 years and have been conscious that I have being doing so in a largely secular context. My own Christian faith commitments have always been in the background, since I've seen my purpose as promoting an account of character virtues that would be acceptable to those of a religious faith and to those who do not accept a theistic worldview. However, I have always known that this common ground and ecumenical approach, which recognises that everyone has a perspective on character, when considered from my own faith perspective, was incomplete and only presented half the story. My conception of education, born of many years of teaching, is concerned with character virtues that relate to human flourishing, to the kind of people human beings have the potential to be and ought to be. Previously, I contributed on a project to introduce Thomas Aquinas (1225-1274) to educators. My contribution was inadequate, but my two co-authors, with their strong Dominican and theological 
connections, were able to offer significant insights (see Walters, Arthur and Gaine, 1999). Their Thomist insights articulated the view that virtues are qualities of successful living from a teleological perspective and that education seeks to develop our character, building the qualities, which enable us to see, judge and act so as to live well and live right. I have become more aware over time that my own understanding of Aristotle's ethics of character is mediated and comes indirectly through the Christian faith. That is, that there is a God and our lives are directed to union with God. This is not a concern of most ethicists, but Christian ethicists have also promoted a substantive revival of Aristotelian character ethics - that is, a theory on which the assessment of one's character is taken to be primary. I am also conscious that many contemporary educationalists are entirely indifferent to the history of educational thought (see Topping, 2012: 6).

It is my intention in writing this text, therefore, to explore the formation of the person based on a Christian anthropology. It gives emphasis to an analysis of moral issues and moral engagement in education with the ultimate goal of human flourishing. A Christian understanding of character is more than a moral compass set to explore a life of human virtues and earthly flourishing. Its anthropology emphasises the communal nature of the virtuous life and provides a richer approach to the question of contemporary character education than that of the partial, and impoverished, vision of the person that focuses primarily on issues of rationality and autonomy. Modern education theory and practice is oriented towards learning skills, abilities and forms of knowledge deemed necessary to increase our capacity to act successfully - a pragmatic approach that is concerned with ideals of technological and material success. In contrast, I will examine the connection between human nature and human flourishing. I argue that the only way to understand and build our character virtues is to have a clear picture of what the purpose and meaning of human life is, and that, while not disregarding the findings of contemporary scientific anthropology, this picture needs to draw on ancient and medieval sources. However, there is no longing in this book for a golden age past; rather, this book sees the past as full of riches we can use today and in the future.

This book is written primarily for a Catholic Christian-leaning audience, but it also has in mind a general Christian audience with the intention of raising confidence in a Christian approach to character education. The Church has always tried to address everyone and not simply speak to itself, and so I recognise that there is great diversity of philosophies and perspectives on Christian formation (see Pelser and Cleveland, 2021). However, I hope that some elements of my presentation of Christian character formation in the virtues offer support and new insights for those who do not share the Christian faith. This text will explore the notion of human beings as social creatures and a unity of the spiritual and the material. Attending to the spiritual raises issues of transcendence, faith, desire for God and human immortality. Consideration of the material focuses on worldly issues and the social aspects linked to the Church together with the implications of these communal and relational features for character. More generally, in drawing upon Greek thought and Christian revelation, the Christian tradition relates this world and the next. This 
book will contend that Christ is a model, an example and a source of virtue, and Christian narratives, from Scripture to the lives of the saints, have a role in the shaping of character. To educate the whole person in the light of an all-embracing Christian worldview is challenged by secular and liberal ideology and is often seen as irrational to the modern mind. Overall, the text seeks to demonstrate that many aspects of a Neo-Aristotelian-Thomist theoretical underpinning for Christian character education hold out a viable option for Christians, generally. It therefore argues the case for the educational potential of Christian character education, which has faded in prominence in schools and educational policy.

Anthropological and theological concerns are at the heart of the Christian educational enterprise, and Christianity recognises that education aims to form human beings within a cultural context. Whether knowingly or otherwise, our often implicit and unarticulated ideas about the origin, nature and destiny of human beings and the meaning of the good life influence educational aims, pedagogy and curricula. In contemporary educational circles, theory is influenced largely by positivism and secular norms that combine to exclude or marginalise theological elements. Indeed, many Christian institutions mirror the educational philosophies and practices of secular institutions. However, an authentic Christian approach to character education is teleological, and its end-point is a relationship with God.

For Christian educators, human flourishing is inseparable from God's active relationship with human beings and this entails moral consequences for human life - ultimately through the moral progress of building Christlike virtues. Christian character is the possession of those qualities, which essentially relate us to God. Character education, on this account, is about 'waking up to life', helping us grow and develop through a purposive, intentional and life-long process. It grounds character and the virtues in relation to a person's creation in the image of God that accepts that we are each unique unities of body and soul, endowed with intellect, will, instinct and emotion. Christians are called by God 'to be conformed to the image of his Son' (Romans 8:29-30), and this can be treated as a process of character formation requiring conformity to both revealed law and natural law. The former is found in Scripture and Tradition, while the latter is reasoned from universal principles that govern human action and are accessible to all through the proper use of reason and insight. What we appear to have lost, I contend, is a teleological understanding of human life: that is, human nature in its flourishing condition, as it could be if its telos were realised. Such an understanding makes sense of moral character and the need to habituate the virtues in order to flourish in a characteristically human way. Neglecting teleology and human nature has proved restrictive for character formation. Where character formation through the virtues is possible, so a person not only achieves their own good, but also that of those others with whom we recognise as sharing the same intrinsic human dignity. Each person possesses this human dignity irrespective of their achievements or particular status accorded them by society. A Christian approach to character virtues places emphasis on imitating Jesus Christ, who is the fullest expression of human nature and flourishing. 
My view of character, and indeed some inspiration for writing this book, was taken from my reading of Alasdair MacIntyre's works and recognising that they offer a positive programme to restore the moral life that is rooted in Aristotle and Thomas. While MacIntyre (1981: 259) reminds us that ' $\mathrm{t}$ ] he Aristotelian tradition can be restated in a way that restores rationality and intelligibility to our own moral and social attitudes and commitments', he also offers the living tradition of Thomism as an intellectual way to rediscover the moral life. Thomas, like Aristotle, is a good place to start when considering what it is to live a good life, as he provides us with an understanding of what human beings are and how and why they act as they do. Thomas provides us with a lens for looking at transforming education that is still relevant today, and he himself used Aristotle in his own day to understand character formation. MacIntyre essentially informs us that modern moral philosophy is divided, fragmented and inadequate to provide us with an authoritative solution to the crisis of modern moral life. His solution is to emphasise teleology in which norms are given in a social context. These norms are made significant within a narrative tradition of practising the virtues. These virtues are determined, practised and judged through reason (phronesis), but the virtues, for MacIntyre, are built-up, practised and sustained in everyday life by ordinary people. They are inherently practical and rooted in common sense; their practice is not a theoretical or intellectual exercise. Therefore, I am convinced that the Enlightenment project of 'rediscovering new rational secular foundations for morality' (MacIntyre, 1981: 177) was futile because it rejected the teleological view of human nature. Like MacIntyre, I believe that an Aristotelian-Thomist lens restores our moral compass and presents a rationally defensible conception of the good life (see MacIntyre, 1996: 7). This gives us a focus on excellence (arête) and the character of individuals developed through exercising practical reason in concrete situations, together with a life embodied in the virtues and their practice firmly based on the ethics of character. I agree with MacIntyre that the idea of the 'rational' moral agent, understood as an unaffected observer who objectively examines facts and acts on them, is not an accurate description of human nature or of the reality of the social context in which we live (see Harak, 1993: 27).

This book is written from a neo-Aristotelian perspective in the form developed by Thomas and others who represent the best in the Christian moral tradition. This perspective is called Aristotelian-Thomist because many of Thomas's thoughts on character formation are rooted in Aristotle. I seek to advance a substantive account of Christian anthropology for character and virtues while allowing for a reasonable pluralism within a modest diversity of interpretations of the content and application of an educational approach. Such an approach provides a promising way to overcome some of the confusions on Christian ethics today. I accept, here, that Christian moral teaching cannot co-exist with individualism, instrumentalism, consumerism, materialism, relativism and hedonism - in short, the reduction of the world to mere materiality, particularly reducing to the empirical all that is human. Taylor (1991: 1) calls it 'the malaises of modernity', recognising modernity's spiritual and moral emptiness causes us to be detached 
from place and purpose. What is real in the world cannot be reduced to solely what can be measured and calculated. My teaching career has been strongly opposed to an education system that runs on quantifying everything and intentionally ignores that not everything that counts can be counted.

Beyond providing an overview of the thoughts of others, I offer a framework for use in some Christian educational contexts. I write as an educationalist and not as a philosopher, much less as a theologian. This is therefore not a book that will treat all the issues and arguments at a level that specialists in Christian ethics would find satisfying, but rather it is directed at practitioners in education and those in the social professions. I adopt a teleological approach to ethics, and this applied virtue ethics approach focuses on the character of the moral agent but does not ignore duty ethics, which focuses on behavioural norms, or consequence or utilitarian ethics, which focus on outcomes. In reality, both virtue ethics and deontological ethics are necessary for an adequate moral system since each has intrinsic value as we have a Christian duty to become a certain kind of person and a duty to follow correct moral rules. The idea of teleology stresses the process of 'becoming' and a sense of moral striving, of moral character and virtue. It points the way towards responsible, ethical living and decision-making. This book has therefore been written according to a realist, teleological ethic based on natural law and motivated by the Christian theological virtues of faith, hope and love. Consequently, when I say that children should learn to be kind and compassionate, I am not expressing a personal preference, I am making a truth claim.

Chapter 1 introduces a number of background issues. It begins with the idea of Christian character education within a theological frame of reference and explains how, in this context, it is premised on a particular understanding of human flourishing, which is derived from a Christian understanding of human nature. It introduces a theology of character and some of the challenges to moral character from moral theologians, including revisionist understandings of authority within the Church together with the particular challenge of proportionalism and intersectionality. The chapter introduces a number of philosophical and theological terms by way of background.

Chapter 2 examines Christian character formation from the perspective of the Early Church Fathers, together with how they incorporated aspects of ancient Greek philosophy of ethics. The chapter looks at a Christian anthropology of character as a way of introducing Aristotle, Augustine and Thomas. It asks whether an Aristotelian philosophy is compatible with a Christian theology of character and outlines Aristotelian-Christian comparisons.

Chapter 3 introduces Thomism and character education and outlines what Thomas has to say about a theory of Christian character education. It looks at how the virtues relate to each other and how theology helps us understand them. The chapter describes how Thomas conceived of the virtues and moral formation and examines the links with conscience and freedom in the process of formation as a Christian. The work of Pinckaers and the implications it has for education is highlighted. The chapter introduces how twentieth-century Thomism understood 
education in this context. It also describes the history of Thomism in education within the United States and the UK.

Chapter 4 examines a Christian philosophy of character ethics together with a Christian pedagogy. The chapter reviews the Catholic Church's teaching on virtue in education and examines the teaching of virtue. It introduces a virtue approach to teaching and learning character through the Jubilee Centre's A Framework for Character Education in Schools. It discusses the framework and looks at the kind of curriculum programmes that such a framework leads. It proposes this secular framework as a possible starting position for a Christian approach.

Chapter 5 looks at how Christian conceptions of character virtues are understood and taught in schools and examines Christian ideas of the intellectual, moral, civic and performance virtues. The chapter illustrates this process by providing concrete examples from the content of Catholic educational programmes on how to grow in the virtues.

Chapter 6 outlines a theological framework based on the Aristotelian-Thomist approach for character formation as a way of providing a comprehensive virtuebased understanding of character formation. The chapter offers a system of beliefs and ideas that can help to plan and discuss an approach to character formation within a Christian context.

Finally, the brief conclusion offers some afterthoughts.

Each chapter concludes with annotated readings and questions for discussion. 


\section{Character formation and theological challenges}

The point of Christian character education or formation is primarily to enable faithful Christian living, and Christians have made use of the language of virtue to describe the Christian life. This Christian living is not simply a series of obligations and norms, but a relationship of knowing and loving God and this is only made possible through and in Jesus Christ. The formation of Christian character virtues therefore only makes sense within a faith community of which an individual is part. The fact that our secular culture is turning increasingly to the language of virtue ethics, or character ethics, can be observed in that we are no longer solely concerned with policies and social issues, but now link them to the character of those public figures who advocate them. There is growing popular concern for virtue and character, but we cannot assume that this language is in any sense Christian in inspiration. Yet the deepening of one's moral character through belief in God and the transforming work of the Holy Spirit has always been important in Christianity, and the community that shapes the Christian virtues is the Church. However, secular culture, particularly in its more aggressive forms, can weaken the Christian's intuition that religious belief in God is necessary for developing moral character. All education is normative to the extent that it cannot but embody some ideal of human flourishing together with some account of the role of parents and teachers in actively promoting this ideal of flourishing. Character ethics seeks to restore the coherence of moral virtues by providing a teleology (purpose, goal), and this teleology is revealed in Christianity - which is union with God.

If we claim that education prepares human beings for life, then it follows that we need to have some conception of what the purpose of that life is. The main goal of education is therefore to help human beings become more fully human. Teachers need to ask themselves what kind of person they are seeking to promote, for it is not sensible to pursue an educational aim without considering what its concrete realisations would involve. All teachers need to be conscious of the kind of formation they offer their students since we cannot escape the fact that all education is simply the practical expression of our philosophical convictions. Education, in the form of schooling, is intentional, structured and institutionalised with pre-determined learning objectives for teaching. Education is, of course, lifelong, and not completed in school. We need an anthropology that provides an 


\section{Character formation and theological challenges}

account of human nature (see Maritain, 1943: 1): an anthropology that provides us with knowledge and understanding of our origins, nature and destiny. People are, deep down, alike in some fundamental ways. This basic truth is often overlooked in modern philosophies of education. Consequently, the account of the good life is not merely a disposition to action, but must lead to the pursuit of purpose: the goal and destiny of human life.

As Maritain (1943: 2) reminds us, education is about 'Becoming who we are' and is essentially a 'human awakening'. Education in this sense is an endless process of 'becoming', and life, insofar as it is the life of human beings, is always moral because the weight of choosing morally is impossible to avoid. Maritain (1943: 9) uses Thomas Aquinas to define education as the process by which human beings are shaped and led towards fulfilment. We are human beings because we are made in the Image of God (Genesis: 1: 26-28) and this Imago Dei is central to the Christian understanding of anthropology. Imago Dei is the basis for our relational capacity with one another and God and therefore has ethical implications. Sertillanges (1989: 17) said that the 'qualities of character have a preponderant role in everything'. Austin (2016) notes: 'Christian formation refers, not to being forced to fit a pre-determined mould, but to the growth of the disciple into a unique image of Christ' and 'the process of Christian formation is therefore a process of becoming, through virtue'. In sum, God's image is seen in our character and in what we are destined to ultimately become, which will fulfil God's expressed purpose for humanity. As Palmer (2016: 117) says: 'If character reflects one's fundamental vision of reality, the ultimate vision for the Christian is a life centred on God and oriented in such a way that intellect, will, and affections are all aligned with God's purposes'. It is therefore by good acts that human beings contribute to the formation of their character, and each person must decide whether they wish God's image to be reflected in them by co-operating with God's grace. Theology, for Christians, therefore, rather than educational philosophy, must primarily direct character formation.

\section{Christian formation}

Farley (1995: 163) says: 'What a person believes and values, what he or she dares to become and be, or what communities he or she wills to support and cherish, have tremendous impact on shaping character.' Therefore, in the Catholic Church, the sacraments, Christian fellowship and experience in the Christian community are invaluable resources for building character and making moral decisions. The Catholic Church has traditionally relied on formation, education and socialisation into the faith community after Baptism to produce moral citizens and good practising Catholics. Formation is what happens to a person living in community, but it is not simply about children in schools nor does it come to an end during life. The main elements of this Christian formation come from prayer and worship, listening to and reading Scripture and Christian doctrines, offering service to others, as well as teaching and learning. All of these elements inform, instruct, inculcate and ultimately seek to form our entire being because the self we become is largely determined by 
the commitments we make. A Christian anthropology views humans as material and immaterial, body and soul, not one or the other. This is why a Christian anthropology knows the limits of developmental theories arising from the social sciences, as those theories ignore the spiritual and theological dimensions of the person in Christian community. The Church has traditionally been understood as a school of virtue that helped shape character, not so much as through telling us what to do, as encouraging us to ask the question: Who shall I become? Formation therefore is not limited to the task of formal catechesis only, but is the formation of humankind into the image of Christ. Every aspect of the Church's life is directed at formation, to create a formation that is a profound, comprehensive and dynamic immersion of the person in the traditions of the Church.

Christian character formation is distinct from non-religious approaches to character. There is no neutral starting point from which to think about the moral life. This is why Stanley Hauerwas (1983: 1) believes that all ethical theories are particular to certain historical communities, and why he suggests that ethics always requires a qualifier or adjective such as 'Jewish', 'Christian', 'utilitarian', 'pragmatic', 'humanity' or 'modern' to denote its social and historical nature as a discipline. Consideration of the moral life is an activity relative to particular times, places, commitments and communities. The Catholic Church, for example, understands reality as sacramental, which means God is real for everyone in the ordinary concrete details of their daily lives. God is reflected in our connections with each other and is the basis for human dignity, and God is ultimately the reason we are to be treated with mutual respect, regardless of background. Hauerwas emphasises in his writings the importance of character in the moral life, and of the distinctiveness of a Christian character.

Catholic moral theology, understood as an approach to Christian character and human action, is often complex, disputed and fraught with misunderstandings. The purpose of theology here is 'faith seeking understanding' in order to help people live good lives. In theology, reason clarifies faith, but in Christian philosophy, faith inspires reason. Christian character formation involves growth in knowing, which leads to moral relationships, moral living and human flourishing. When Hauerwas wrote Character and the Christian Life in 1975, few were writing about the formation of Christian character and virtues. Hauerwas noted that even Christians received any talk of character and virtues with suspicion. Not much has changed today, despite character and virtues being discussed and written about more widely with a growing recognition that virtues are beneficial to individuals and to humanity in general. We can agree with Hauerwas (1995: xiv) that 'most of the work for understanding the moral life in terms of virtues and character is still to be done'. Character and virtues are also viewed with suspicion by many social scientists because they claim, with some justification, that there is too much focus on individuals, and the virtues they possess are qualities that fundamentally reside in individuals as opposed to society. However, in the end, the good is only realised through right human intention and choice, and this choice can only be made by an individual who is free and accountable. Modern psychotherapy has often 
focused wholly on the hurts and problems that people face resulting in a victim mentality. In other words, we are moved to believe that we are not responsible for our negative actions since these are caused, the therapist tells us, by what other people have done to us.

Catholic and Protestant perspectives on character and virtues as constitutive of the Christian moral life give first place to God's grace and generally adopt a moral approach in which the will of God is a source of obligation. Protestant ethicists tended to reject what they saw to be an excessive Catholic focus on human action. They felt that Catholics focused too narrowly on the criteria when assessing the goodness of human actions and consequently made judgements regarding specific cases. This led, they believed, to individual guilt followed by the need for penance undertaken through confession to remedy sin. In contrast, Protestants focused more heavily on hearing Scripture and on accepting that we are brought into a relationship with Jesus, distinct from our own effort and work. The emphasis here is on faith and grace. However, it is a parody that Catholics were thought to have extremely high standards that were unachievable for the virtuous life, but which were enforced loosely, while Protestants had moderate moral standards with realistic prospects of achieving a virtuous life, but which were enforced strictly. Catholics, in fact, have viewed human action in the light of God's grace. Today, there is growing convergence between Protestant and Catholic ethicists. Catholics have learnt to appreciate the role of Scripture in Protestant ethics, while Protestants have learnt to rediscover the understanding of the natural law and the role of worship in character and virtue formation (Svenson and Van Drunen, 2018). There has always been overlap between Catholic and Protestant positions, and today there is greater convergence on moral thinking in many areas (see Grobien, 2019; Nabers, 2005).

Secular approaches to moral philosophy predominate in the literature. Collicutt (2019: 3) begins her work on Christian character by observing that " $[\mathrm{t}]$ he use of the word "formation" to describe the Christian life is a bit like Marmite. It is beloved of some and loathed by others'. The same could be said of the words 'Christian', 'virtue' and 'character', with some believing these words are positive and liberating while others see them as repressive and restrictive of human freedom. For many, the whole idea of the Christian formation of character seems too severe and perhaps even unpleasant. The very idea of God being connected with our moral character causes Richard Dawkins (2006: 31) to exclaim:

The God of the Old Testament is arguably the most unpleasant character in all fiction: jealous and proud of it, a petty, unjust, unforgiving control freak; a vindictive, bloodthirsty ethnic cleanser; a misogynistic, homophobic, racist, infanticidal, genocidal, filicidal, pestilential, megalomaniacal, sadomasochistic, capriciously malevolent bully.

Dawkins does not argue (what might be a reasonable case) that belief in God is not a necessary condition for morally good character, but rather he simply asserts that belief in God itself impedes moral progress and reasoning. 
Bertrand Russell (1992: 595) said the same when he penned the line: 'I say quite deliberately that the Christian religion, as organized in the churches, has been and still is the principal enemy of moral progress in the world.' Both identify Christianity as the main offender here, but they also mean that religious belief is irrational, and they largely consider only the institutional aspect of religion. In contrast, Christian theism has traditionally maintained that the moral virtues of character are grounded in God, who is the source of these virtues. Contemporary secular humanism grounds these moral virtues exclusively in human beings, while the popular nihilism within modern culture maintains that moral virtues have no ground at all and are therefore illusory. Moral nihilism simply argues that there are no moral truths and that no beliefs, far less Christian beliefs, are reasonable or justifiable and so ought not to be believed. Modernity conceives of morality as either or both the creation of our times and places (our environment) or the product of our genes and neurons (our DNA) - both explanations effectively denying that we have potential free will or responsibility for the formation of our own character. Christian morality is also reduced to an ethical scheme that is offered as a practical morality of love and kindness, which does not require belief in a supernatural God. This view is effectively a secular Christianity, a worldview that anyone could adopt that helps us socialise and live in harmony with each other. Modernity's many ideas of moral character offer us no good reasons why we should take them seriously. This ongoing debate has made the connection of moral virtues with God and religion intensely controversial.

The Christian rejects a purely secular account of virtue formation, but shares with various forms of Aristotelianism a recognition that character formation is a developmental cultivation of good habits, the shaping of conscience and the inculcation of virtue. For the Christian, character is not solely what we choose, but rather must be viewed in the light of what has been done to us and for us in Christ. The notion of Christian character envisaged in this text transcends the temporal, the material and the secular and points us towards the eternal, the spiritual and the religious (see J. F. Gilson, 1953: 270). I recognise at the outset that an AristotelianThomist approach is profoundly at odds with modern secular culture and that not all Christians would accept such an approach. Indeed, Catholic moral theologians are not in agreement with each other over the content nor even on the authority of the Catholic moral tradition. No single approach to Christian ethics has gained acceptance among Catholic theologians because some believe there is more than one way of going about Christian character education. Nevertheless, an Aristotelian-Thomist virtue ethics, it will be argued, informed by complementary theoretical tools from social theory and developmental psychology, offers a tradition-based and pragmatic theoretical framework for conceptualising Catholic character education. It emphasises the connectedness between the moral virtues, moral character and the telos of a human being. It offers help in an age of impoverished moral vocabulary, in which the language of character and virtue is insufficiently rich enough to convey its full meaning to Christian and non-Christian audiences. 
This text accepts that a Christian character formation in the virtues must be grounded in theology as well as an appropriate Christian philosophy of education, but, importantly, without the theology part, you cannot call it Christian. Theology ought to guide and direct the content, purpose and methods of character virtue formation in the sense that theology has philosophical implications for education. If Christian character formation aims to transform the whole person into the likeness of Christ, then a theology of education, which can explain how theology and philosophy relate to each other in addressing character formation, is necessary. Throughout this text, both theological and philosophical reflection are used to furnish the basic postulates of an understanding of character virtue formation. However, it is outside the scope of this book to provide a fully worked out theology of education. Notwithstanding, it is certainly the one thing that is largely missing from modern Catholic understandings of moral virtue education. We need an acceptable philosophy of education that builds on an appropriate theology of education.

\section{How should I live?}

For the Christian, 'how should I live?' prompts questions that are more fundamental: 'Who am I?', 'What sort of person am I, and what sort of person am I meant to become?', 'What sort of person should I become because I believe in Christ?' Searching for a path to the good life requires us to reflect on the way we live and to consider how we learned to live that way and whether or not we intend to continue living that way. To these questions, different intellectual traditions and different strands of Christianity give different answers. Many Christians who discuss the religious nature of morality think it is all about a focus on obligations; following rules and laws that either the Church delivers or God commands. In following these rules, the Christian seeks something - eternal life - but the reasons for following the rules are sometimes unrelated to the intrinsic good of living according to them. In other words, there may be a connection between the rules and the good life one seeks, and, for some, the expectations of a reward for following the rules is instrumental in nature. In contrast, living morally in the normative sense (living your life the way you should live your life) is not an instrumental path to something else and is therefore a richer and fuller way to engage with Christian morality. One follows the rules because they enable one to realise the most fulfilling and satisfying life, which is the love of God and neighbour for their own sake. It is not simply about what rules we are to follow, but rather what we are to be.

In the ancient classical world, according to Hadot (1995), the search for wisdom was considered a mode of being, and the role of philosophy was seen as being, acting and seeing the world in a specific way. Philosophy was not merely a discourse but a life choice, a way of living. It was this philosophical approach that dominated discussions of character and virtue formation. The exception to this was the people of Israel who conceived of the world differently; you could say that they adopted a theological approach to how we ought to live, combined with the 
self-corrective practices such a life requires. The arrival of Christianity ensured that a growing theology would now dominate any approach to character virtues, to such an extent that it was impossible to think about character formation in the virtues as something separate from religion. By the late nineteenth century, at least in Britain and the United States, new philosophies emerged that began to question the dominance of theology in character formation, and various secular philosophical discourses, not philosophy envisaged as a way of being and living, began to lead the debates about character. Since the 1960s, there has been a turn to psychology rather than philosophy in the search for understanding the role of character formation. Moral theology, within the general public domain, plays practically no role in these discussions.

\section{Theology and character education}

Theology is the study of the nature of God, but includes reflection on human conduct in relation to God. A Christian approach to character and virtue formation must therefore have a sound theological basis for it to be considered Christian. It must be infused with theological depth, be theologically informed and be intentionally conceived as preparing the student for God's purpose. This kind of Christian character formation is for those who are, or are seeking to be, committed followers of Christ. We could ask, 'What difference does God make to our educational philosophy?' 'What does theology have to say in answer to educational questions?' While both philosophy and theology are concerned with the nature, goals and means of education, ultimately philosophy is no substitute for theology. If we believe that education is directed towards transcendent goals such as salvation and eternal life with God, then we need to speak of a theology of education. If education is a lifelong process of learning how to return to God our creator and a route to being transformed into the likeness of Christ, then we need theology to help us search for the meaning of education. The educational process behind this character formation becomes a practical expression of one's theological commitments as a Christian and will influence how we believe, think, learn, act and treat each other. Indeed, viewing oneself as a follower of Christ is a major commitment required to belong to the community that is the Church. However, because of the underdeveloped nature of a theology of education in the Church, it is often difficult to see a direct road from education to salvation. A more attainable, proximate goal is to build character, but without a theological map it is easy to get lost. With a clearly worked out theology of education, we may hold out the hope for, and be able to educate for, a definite character and give some shape to a student's inner life, and, through an ongoing process of formation, to act and behave in a Christ-likeness way.

Moral theology (Christian or theological ethics) focuses on the implications of faith for the way Christians live their lives. Moral philosophy (philosophical ethics) reflects on the nature of the moral life without reference to Christian faith. For the Christian, the absence of theology will lead to a poor philosophy of education that 
focuses solely on the direct experience of the student. Commenting on the Catholic moral tradition, Gula (1989: 1-2) notes that:

today we want to avoid separating morality into either a natural 'rational morality' or a revealed 'faith morality'. The former yields a pure humanism, the latter a sectarianism. When taken alone, neither is fruitful to the deepest desire of the Catholic moral tradition to address genuine human concerns as a believing community in a language accessible to nonbelievers as well.

The idea of rational morality is widespread, with simple texts such as Rational Morality: A Science of Right and Wrong (see Johnson, 2013) proving popular, while Christians with particular sets of moral beliefs are seen as bigots and as unthinking. Christian character formation should not be understood as something we give to a person, but rather as an authentic means to facilitate the search for personal meaning and purpose in life through developing a relationship with a transcendent God. Education for the Christian is more than simply cultural transmission, since with the guidance of theology it initiates the student into knowledge that transcends human culture. Developing an ethical life within a Christian theology is part of the purpose of Christian education, and Ravaisson (2008: 69) observed: 'Such is the secret of education: its art consists in attracting someone towards the good by action, thus fixing the inclination for it. In this way a second nature is formed.' Because the student is called to a supernatural destiny, education is ultimately a theological activity. The student should know God as eternal, beyond and greater than themselves, and only a theology of education includes this necessary transcendence in the goal of education.

\section{The presumption of unbelief}

Today, we live in a period of unprecedented technological change that has resulted in radical questioning by Christians and others as to how we should live. We also live in an age that is increasingly denying the existence of God, with many living as if God does not exist. Charles Taylor (2007: 19-20) attributes this process of secularisation to three causes: (1) public spaces being 'emptied of God or, of any reference to ultimate reality', (2) falling-off of religious practice, people no longer attending Church, (3) the growth of societies where 'belief in God is no longer axiomatic. There are alternatives'. If you live in the Western world, you will know that its culture is averse to the idea of the transcendent and any idea of unchanging truth - there is a 'denial of the transcendent' which has also penetrated Christian minds through a secularisation of their consciousness. This is often why Church institutions submerge into a bland secularism when they are not rooted in any theological position. If Christian life loses its reference point then it presents us with a notion of human flourishing which recognises no valid aims beyond itself. There has also been a loss of belief in ideas such as sin and in any arguments that human life has a purpose. In contemporary schools, education, philosophy and 
theology are largely divorced from each other, and truth is perceived as relative, with many teachers and students preferring not to judge between good and evil, but instead they celebrate being open-minded; rather than judge what is good, they prefer to judge that it is good not to judge at all. This widespread subjectivism and plurality of opinion make people uncertain about what is true and unable to reach a consensus on questions of the moral life. While there is widespread confusion and scepticism in moral questions, there is also a sense in which human beings hunger for something that will inspire them to live well and flourish.

As Hauerwas and Wells (2011: 49) write, 'Christians can no longer depend on the habits of the surrounding world to reinforce what they think makes them Christian.' We have moved in the West from a belief in God to a belief in ourselves. This kind of secular thinking maintains that Christians hold beliefs that are simply a collection of prejudices that have the effect of obstructing the very comprehension of things. Consequently, our age has encouraged new ways of being, which have resulted in demands for new ways of acting. This radical secularism has tended to replace truth with consensus. As Ratzinger (1996: 31) says, 'how fragile these consensuses are and how quickly, in a certain intellectual climate, partisan groups assert themselves as the only authorised representatives of progress and of the responsibility, is before us all'. Morality in this view is reduced to 'describing' reality without 'prescribing' anything - it has no other end than the description of the practices and customs of different people. Education in this sense is therefore about learning how different people behave, not teaching about how a person should behave. It can lead to a thoroughgoing scepticism about our ability to know and understand any truth. Many have accepted the basic secular framework of language and ideas that informs the current debates about education, which means the Church often appears to speak a 'different language' that seems ludicrous to many within and outside of the Church. This is not assisted by moral theologians using a vocabulary which is both complicated and confusing. It is therefore not surprising that many Catholic students have a poor theological knowledge base, which is the product of a softer, less dogmatic, more ecumenical, religious education.

There is clearly a plurality of ethical methodologies, secular and religious, and a greater emphasis on lived experience and a widespread recognition of the lack of absolute certitude on specific moral issues of our time. Common discussions of moral issues in the academy generally hold that moral beliefs are simply social constructions and consequently have no validity beyond what we attribute to them. Some even say that there are no moral facts and hence no truth. Where does this leave the Church as a teacher of moral truth? The teaching ministry of the Church seeks to foster a person's growth both spiritually and morally. The Church is concerned with both education and nurture, which are not seen as separate, to help Christians grow in a particular way of life. However, many Christians of all denominations do not follow the official or even suggested teachings of their churches on specific moral issues and yet paradoxically expect their Churches to take a stand on a range of moral issues, from climate change to sex trafficking. We appear to live in an age in which Christians all too often eagerly and uncritically embrace the latest fad in education. The 
moral teachings of Christianity often fail to make a decisive impact on the actions of students attending faith schools, despite the Catholic Church's cogent theory of human conduct - at least as it is expressed in the Catechism. Within this new moral climate, Catholics are officially encouraged not to make moral decisions based on 'the spirit of the times' or what the majority happens to think at any given moment in history. The combination of individualism and instrumentalism in public education has given way to a rise in emotionalist social justice that is ill defined and which renders any substantive theory or view of life and the good challenging. It is akin to having some moral virtues but without any solid foundation or structure by which to define and contain them. As G. K. Chesterton wrote in his book Orthodoxy (1908):

The modern world is not evil; in some ways the modern world is far too good. It is full of wild and wasted virtues. When a religious scheme is shattered (as Christianity was shattered at the Reformation), it is not merely the vices that are let loose. The vices are, indeed, let loose, and they wander and do damage. But the virtues are let loose also; and the virtues wander more wildly, and the virtues do more terrible damage. The modern world is full of the old Christian virtues gone mad. The virtues have gone mad because they have been isolated from each other and are wandering alone. Thus some scientists care for truth; and their truth is pitiless. Thus some humanitarians only care for pity; and their pity (I am sorry to say) is often untruthful.

There are many well-meaning people who strongly support feeding the poor, visiting the sick, supporting the innocent and so on, and who have a belief in the virtues of the Judeo-Christian tradition while at the same time denying Christianity. However, to have Christian virtues without a belief in Christianity is, as Chesterton puts it, to have a world where the 'virtues have gone mad because they have been isolated from each other and are wandering alone'. The virtues are virtues in part because of their dependence on one another to serve as correctives within a coherent Christian moral framework.

The Catholic Church, in particular, has traditionally focused its moral doctrine on $\sin$ and the laws that are broken when a sin has been committed. This focus has been aimed at identifying sins that need to be confessed in the sacrament of penance. When a series of manuals was first begun in medieval times, they were not intended to say anything about people's character formation as Christian disciples, but to assist priests in hearing confessions. Complex moral norms of the moral life were reduced to laws and rules that were to be enforced and obeyed. A legalistic and rigid approach was reinforced by a theology of voluntarism and a philosophy of nominalism developed by William of Ockham (1285-1349) in contrast to Thomas's teaching on freedom. This regulative approach, preoccupied with obedience to commandments and laws, departed significantly from the Aristotelian-Thomist understanding and treated the theological and moral virtues 'as sources of obligation rather than as the dynamics of moral living' or as principles for the good life (see Spohn, 1992: 60). Thomas's philosophy was reduced to a 
consideration of the virtues and vices as laws and sin, and divine commands or rule theories with a concern for sin, external actions and universal claims still predominate in Catholic moral teaching. Today, many Catholics believe that simply issuing condemnations or invoking a law is an inadequate way of dealing with the complexity of people's lives and the decisions they make. They are attracted to Pope Francis's calls to embrace the spirit of the laws, not their rigidity (or even letter) and his warm appeal to God's mercy.

The Pope's emphasis on mercy is generally in line with Thomas's definition of mercy in the Summa (see ST II-II, q. 30, a.1). Mercy is the virtue of forgiveness and in Matthew 5:7 we are told 'Blessed are the merciful, for they will be shown mercy'. Thomas taught that 'of all the virtues which relate to our neighbour, mercy is the greatest' (II.II, q. 30, a. 4). Mercy is certainly something we do - not simply something we feel. It requires action to be considered an authentic virtue and this action meets someone's need, not just feeling his or her need. The practice of mercy fundamentally changes or transforms a person by making them more Christlike - which is in effect becoming more genuinely and authentically human since Jesus Christ is both the Image of God and truly human. Therefore, it is worth aspiring to be merciful, to desire its infusion in students, and to work for it as part of our character formation.

Education is intended to shape us so that we are led towards personal fulfilment and character formation as a human being. However, character virtues have not occupied a large space in current debates about the Catholic moral life. While virtue language has been part of the Catholic ethical tradition, character virtues have, until recently, played little part in fundamental moral theology. McCormick (1989: 3-24), in reviewing different moral theologies between 1940 and 1989, did not identify the study of virtue as one of the 'significant developments'. It appears most authors limit themselves to discussions about the virtues. A more pronounced virtue approach only arose in the 1990s, and, as Austin (2017: xv) notes: 'theological ethics has found in virtue a language that resonates deeply with human experience and with our best sense of what is worthwhile and meaningful in human life'.

\section{Critical challenges to Christian moral teaching}

Catholic moral teaching over the last 70 years has come under serious scrutiny and critical appraisal from within the Church itself, with many revisionist moral theologians and philosophers disagreeing with certain aspects of that teaching. The very nature of Christian philosophy, theology and the role of the Church have been questioned (see Adams, Pattison and Ward, 2013). There is, frankly, a real and growing indifference to the Church and its teachings. In Veritatis Splendor, Pope John Paul II (1993) reminds us that certain fundamental teachings of the Church are being ignored, denied or rejected. He writes:

In fact, a new situation has come about within the Christian community itself, which has experienced the spread of numerous doubts and objections of a 
human and psychological, social and cultural, religious and even properly theological nature, with regard to the Church's moral teachings. It is no longer a matter of limited or occasional dissent, but of an overall and systematic calling into question of traditional moral doctrine, on the basis of certain anthropological and ethical presuppositions.

We could say that Catholic moral teaching is undergoing change, with various new styles of moral reasoning being advocated, some in tension with each other. Two groups can easily be identified: first, those who see character and virtue being nurtured within the particular community of the Catholic Church, emphasising narrative, community and tradition; and second, those who are more concerned with dialogue in the larger, secular culture and who emphasise the use of the social sciences and philosophy to critique the moral life. The second group tends to prioritise individual expression and autonomy over Church affiliation and authority.

Some Catholics increasingly appear to want 'autonomy' in deciding what is right and wrong, which points to a culture of moral individualism. They adopt the contemporary model of the moral agent as necessarily 'autonomous', that is, free from external influences in their decisions and actions. Pope John Paul II identified the issue somewhat differently in Veritatis Splendor (1993 n4) in saying that:

There is no morality without freedom .... Although each individual has a right to be respected in his own journey in search of the truth, there exists a prior moral obligation, and a grave one at that, to seek the truth and to adhere to it once it is known.

This encyclical, and indeed the whole moral teaching and theology of Pope John Paul II, has come under sustained attack from revisionist theologians (see Curren, 2005).

The second group recognises, and even celebrates, moral diversity, but it is not generally welcomed in the Church, with many bishops viewing it as a negative. Both groups claim that they are working in fidelity to Catholic tradition and that they offer genuine theological points of view. The first group is generally traditionalist and is caricatured in its support for the absolute magisterial norms of the Church's moral teachings, often being branded as socially conservative. The second group is generally seen as revisionist and challenges absolute magisterial norms, considering itself to be socially progressive. The starting point for the former group is the tradition and teaching of the Church, while the latter group appears to have more in common with modern secular culture. This is a polarised picture, which Lawler and Salzman (2010: 2) usefully explain in relation to experience in the Church:

These two schools differ in their approach to experience in the construction of their moral theology. Traditionalists argue that human experience is to be judged by moral norms derived from moral principles; revisionists argue that experience can help to formulate moral norms and principles. The traditionalist 
approach to experience is deductive, from guiding principles and norms to judged experience; the revisionist approach is inductive, from interpreted and evaluated experience to formulated norms and principles.

The revisionist group clearly does not consider the magisterium of the Church to be the ultimate determinant of moral truth, while traditionalists ordinarily look to it.

Selling (2016: 15) consequently argues that there is a crisis in the Church about the way to lead and how to think about the moral life. He believes that few people today actually understand what theological ethics is. One could say that this simply reflects the disciplinary crisis of theology more generally, due to the numerous schools of moral theology which have arisen. Traditionally, Catholic moral teaching was very much based on natural law theory which focused on our nature as human beings, but some critics argued that it tended towards absolute certitude in moral matters. They argued that traditional ethics had a single unchanging view of the 'human being' and that the moral order could be discovered by applying reason to simple observation. Further, they argued that this moral order was established by God and exists for all time, for everyone, everywhere (Selling, 2016: 1). Today the dominant group in moral theology is a revisionist camp committed to an ideological power discourse that more often than not appears indistinguishable from the broader progressive agenda of modern culture in which moral theology itself has been reduced to a kind of 'social ethics'. Other critics within this revisionist camp have examined the right of the Church itself to speak with authority on moral matters, which they claim is either unclear or not authoritative at all. Hughes (1978) wrote extensively about the role authority should play in arguments about the moral life, emphasising the tension between Catholic scholars and the hierarchical Church. He argues that moral matters are sometimes too complex for anyone to teach with clear authority, and that the dogmatic authority the Church claims to possess is not based on ethical arguments but simply on the declaration of authority itself. He advocates that we should live with complexity and uncertainty in matters to do with the moral life. This line of argument is intended to bring into question the authoritative teaching office of the Church and can lead to an overemphasis on individual autonomy in which we feel free to easily reject Church teaching if it does not suit our personal situations.

The Church, at Vatican II, called for moral theology to be rooted more in the Scriptures and in grace, as well as in the recovery of the themes of discipleship and virtue; not just in reason and human nature. The result has been a period of experimentation in moral thinking and a general dislike of moral legalism in which there was a greater appreciation for moral theology integrated with the spiritual life. However, the Church's moral teaching has always been based on four sources: scripture, tradition, reason and experience. It is also worth quoting from Servais Pinckaers's (2001: 1) introduction to his book Morality: The Catholic View as a counterargument to many critics:

Catholic moral teaching is not a mere code of prescriptions and prohibitions. It is not something that the Church teaches merely to keep people obedient, 
doing violence to their freedom. Rather, Catholic morality is a response to the aspirations of the human heart for truth and goodness. As such, it offers guidelines that when followed will make these aspirations grow and become strong under the warm light of the Gospel, Catholic morality is not by nature oppressive; nor is it in principle conservative. It seeks to educate for growth. This is its true mission.

The idea of an objectively identifiable good life does not mean that there is only one single blueprint for living the moral life. Openness and a good degree of flexibility leave room for variety and choice. The truth we seek is vast, and no one can comprehend it fully. The Christian sets their heart on higher things, on the things of God, so that their deepest satisfaction is found in God alone - in a relationship with Christ. C. S. Lewis (1942: 77), who defends objective reality and the importance of such metaphysical concepts as goodness in his writings, noted: 'We might think that God wanted simply obedience to a set of rules: whereas He really wants people of a particular sort.'

There are many within the academy who strongly disapprove of Christianity, particularly any role it may have in education. The idea of Catholic schools with committed Catholic teachers teaching Catholic children from Catholic homes with Catholic curriculum content is seen as reprehensible and even an immoral activity. The charge of indoctrination is immediately raised, which puts even Christian educators on the defensive about the idea and language of formation (see Astley, 2018: 24). Astley (2018: 22) favours a limited use of the term 'formation' balanced by an emphasis on critical thinking. The view that Catholicism forbids a person from using their reason or understands faith as depriving a person of their ability to use their capacity for critical reflection is false. Nevertheless, many, including some members of the Church itself, erroneously think that dogmatic narrow-mindedness characterises people of faith and that Catholic schooling is simply aimed at indoctrination, good behaviour and conformity through a morality of fear and legalism. This image of Catholic education presents Catholic teachers as teaching without evidence, even misusing evidence, as well as misusing their authority as teachers by preventing students from thinking and failing to cultivate the intellectual virtues. Critics charge, often without empirical evidence, that Catholic teachers violate the freedom of their students and do not respect their autonomy. However, Catholic teachers do not set out to indoctrinate, nor is it even possible in a secular democratic society. This narrow image of the Church's understanding of the moral life remains prevalent in the minds of many with moral teaching viewed as legalistic and authoritarian and overseen by an overpowering hierarchy. These critics believe that we are faced with a variety of moral perspectives whose moral claims are unclear and cannot be easily integrated with other claims. We are thus confronted with a confusing set of mixed moral messages.

The crux of this confusion is the tension that arises when Catholics try to hold to the notion of 'exclusive truth' in revelation while living with the modern pluralistic push to acknowledge and accommodate the 'truth' and 
'goodness' of other traditions without compromising their Catholic faith. This is problematic in a Church that was founded by Christ who entrusted His revelation to it, and a Church that considers itself to possess the fullness of revelation in which no other tradition is equal. Secular pluralism also offers no consensus about the true good of human life that would make one's moral commitments obvious and certain. In answer, some Christians point to a concern for formation - to strengthen the Christian identity of Catholics by teaching for commitment. In this formation, the Church has distinctive content, in the sense that we have moral duties not subscribed to by non-Christians. However, this formation cannot be equated with obedience, conformity or being uncritically moulded and changed according to some pre-selected model. While some degree of formation is inescapable in any education system, Christian education involves forming and reforming the self through intelligent evaluation of what is being formed.

\section{Proportionalism}

As implied, earlier progressive revisionists or reformers of Catholic moral teaching take inspiration from Pope Francis. In his public statements, he appears to allude to the theory of proportionalism, which has long been much advanced by Jesuit critics of traditional Catholic teaching. This theory is a form of ethical reasoning known as consequentialism, which permits, under certain conditions, using evil means to achieve good ends. Proportionalism is an umbrella term that groups together several approaches to moral theology, with each being a version of an "ends justifies the means' argument. Various versions of proportionalism flourished in the three decades spanning the 1960s, and many were exposed and attracted to it in Catholic seminaries and universities. It was a reaction to an older method of teaching moral theology and suggested that no human action in itself could be understood as immoral in all circumstances. It arose out of a reaction to a method that too often focused on singular human acts alone and attempted to classify them as licit or illicit, good or bad. Richard McCormack is a clear representative of this revisionism, which he began with an article on 'The New Morality' published in the Jesuit journal America in June 1968. It was a repudiation of legalism and defined the new morality primarily in categories of love, but love relieved of Church constraints. Essentially, McCormack believed that Christian ethics is 'autonomous' and its content intelligible to reason alone. Human and Christian morality are therefore not that different from one another, and Christian ethics simply raises questions that it cannot of itself answer. The Church is thereby a community of moral discourse, and the moral law is not directly dependent on faith or Church teaching. This developing theory of proportionalism increased profound doubt about our ability to say much of anything with certainty in those (and there were many) who were exposed to it. It raised the level of scepticism among Catholics about our ability to know anything about the moral life in the world, and it highlighted disagreements over our respective grounds for moral judgement. Hauerwas (1983: 59-60) was an 
early critic of McCormick's new morality, which he believed was an attempt to make us the authors of our own moral stories, independent of God's authorship.

'Proportional morality' is really the ranking of moral issues in such a way that one will trump another to the extent that it appeals to a comparative evaluation of benefits and harms in its determination of the morality of acts. An act's morality is therefore assessed by weighing the relative good to be gained by a reasoned course of action against the corresponding evil that is threatened. If the good outweighs the evil, the act is judged morally right, despite the fact that the evil may have been done. A distinction is made here between what is 'right' and what is 'good'. The good act is an act that follows the moral rules of natural law, and a right act is an act that is not necessarily a fully good act but creates the lesser of two evils as a consequence of it. There are a number of issues with this way of thinking about morality. First, morality is not simply about doing the right thing, as it also includes being of good character, of which proportionalism takes little account. Second, the approach involves calculus, or quantifying good or evil, but is there a quantitative measure for good and evil? Third, the theory suggests that 'proportionate reason' can determine concretely and objectively the rightness and wrongness of acts based upon intention, but fails to explain how this happens in any rationally meaningful way there is no common agreement on what 'proportionate reason' means. Finally, as John Paul II taught in Veritatis Splendor, proportionalism as a theory of morality is both unsound and unfit for use in Catholic moral reasoning.

Veritatis Splendor offers an account of moral action based on the object of the act (what you choose to do), the intention of the person performing the act (why you did the act) and the circumstances surrounding the action (when, where or how you acted). In order for a human act to be good, three elements that characterise it must be good: the object chosen, or objective nature of the act, must be good; the relevant circumstances that shape the act must be good; and the end intended must be good. The encyclical accordingly discusses and rejects several views about the moral life. Proportionalism, with its emphasis on reason and not on the virtues, can easily lead to an 'I - and only I - decide what is right and wrong' mind-set. Even if the ends we strive for are good, it does not mean that we can choose any means whatsoever. As the Catechism says: 'One may not do evil so that good may result from it' (CCC n. 1756, Romans 3.8). Not only must the intention be good (proportionalism agrees), but the circumstances and the act itself must be appropriate (this, proportionalism does not acknowledge). The theory has been subject to sustained criticism, and many who have adopted it recognise that significant theoretical and practical problems remain, and in reaction to this criticism have accordingly tried to limit its application. Others (see Selling and Jans, 1994) have largely rejected Veritatis Splendor by arguing that the Pope has misunderstood or misinterpreted what they have argued and use the texts of Thomas to try to justify their arguments, even though the Pope has said that their theories "cannot be grounded in the Catholic moral teaching' (paras 75-76). Ashley (1996: 136) makes two further serious criticisms of proportionalism, which can be summarised as, first, 'proportionalism is self-contradictory because it demands that one weighs the values 
and disvalues of an act before judging it to be moral or immoral' and, second, it is 'mistaken in denying that some acts are intrinsically immoral'.

Two Jesuits, Harrington and Keenan (2002 and 2010) have focused on how a virtues approach can offer us the potential for an anthropological identity. In this virtue approach, they give prominence to the common good and our relationships to each other. They argue, rightly, that virtues are not simply about developing individual capacities but are, rather, relational (2010: 8-9). Our relations with others must be made virtuous through an appreciation of the common good, and this entails that we must use the virtues we possess to improve the ways we are related to each otherultimately through love of neighbour. They lay great stress on an appeal to human dignity, respect for individual conscience and responsibility to build the common good. They turn to an ascetical theology (to grow in holiness) to accentuate human growth and to develop a stronger appreciation of the virtues. As they say: 'We look to the virtues as the right realization of the Christian's internal disposition. We cultivate a more integrated view of theology. And animated by love, we look to develop a more relational anthropology' (2002: 8). Essentially, they call for greater co-operation at the level of interpretation to enrich moral theology, while advocating proportionalism. Keenan (2004a: 115) bemoans that the Catholic Church is primarily 'known not for our sacramental life, but for the moral absolutes that we hold: on divorce, homosexuality, abortion, euthanasia, and birth control' and he complains about 'the near idolatry that we attach to our observance of our moral teachings'. Keenan is right to note that the Catholic moral teaching can sometimes strike a condemnatory tone or what Pope (2014: 403) calls a 'rigid and legalistic form of deontology', but he is wrong to go so far as to say that this is idolatry.

For Keenan (2004b: 114), the development of virtues is central to Christian discipleship. Keenan suggests that, by looking at who Jesus was and how He related to others, we find direction on which virtues we need to cultivate, stipulating love as the motivation for his transformative virtues. I believe Keenan was simply building on an earlier catechetical movement also begun in Jesuit Departments of Education in the 1970s. This movement presented God as active not so much in the Church and scripture, but in the experience of human living. It was usually called person-centred, experiential and existential, and its method was discovery, emphasising freedom from authority and tradition. It insisted on the centrality of what it defined as 'human' and sought to improve the material quality of life - the task of the Church was therefore humanisation. Love of neighbour became reduced to the one commandment of Christian moral teaching to the extent that the Christian message was to be found in humanity and its service, particularly to the poor and oppressed. Love of neighbour, it could be said, has been transmuted into tolerance for everything your neighbour says or does. O'Meara (1997: 258) puts it differently when he observes: 'One virtue, charity, attractive in its Christian radicalism, replaces grace as the distinctively religious and Christian factor in the new virtue ethics, a position alien to the thought of Aquinas.'

Keenan's (1995: 711) focus is on a modified version of the cardinal or acquired virtues, as he says: 'The task of virtue as defined, therefore, as the acquisition and 
development of practices that perfect the agent into becoming a moral person while acting morally well. Through these practices or virtues, one's character and one's actions are enhanced.' Some consider Keenan's moral scheme to be one that affirms moral pluralism as a good, which results in emphasising the virtues for good behaviour within the pursuit of the common good. Others see a downgrading of the theological virtues and the transformative power of grace, even if Keenan recognises their importance (see Eagers, 2011: 963). Anderson (2020: 2) certainly believes that it is very un-Thomist to discuss a Thomist account of virtue without reference to Thomas's theology of grace. He writes:

renditions that claim, either explicitly or by omission, to be (a) a complete presentation of Aquinas's account of the virtues, while (b) reducing them or completely omitting them in an attempt to bracket the theological aspects inherent to Aquinas's account of the virtues, fail to be authentic representations of Aquinas's thought on virtue.

(Anderson, 2020: 308, italics in original)

There is certainly an attraction in Keenan's writings to an emphasis on love, conscience and mercy over knowledge, but it cannot be the case that, just because something feels right and true to oneself, it therefore is right. Interestingly, the approach is a good example of how some have used virtue ethics to distance themselves from the Church's official moral teaching. An example of how this can be applied in Catholic education is seen in Catholic teacher Katherine Hennessy's doctorate on 'Education as Formation: Virtue Ethics and Catholic Formation' completed at Berkeley Graduate Theological Union in 2013. The thesis claims to argue for a tradition-based and pragmatic framework for conceptualising Catholic education understood as the holistic formation of persons. She also claims to employ an Aristotelian-Thomist philosophy. However, the framework that is outlined essentially argues that Catholic educators, if they have good intentions and because they are free individuals, can ignore Church teaching on virtuous living in their journey to become the person they are meant to be. The thesis ignores the fact that virtue ethics as understood in Catholic teaching does not equip one to invent truth itself, but rather assists us to do what is to be done in any given situation consistent with objective truth. The uses to which the Church put Thomism were multiple, but it can be observed that a broad Thomism was used as a way to discuss education, particularly Catholic education. Many of the philosophers, educationalists and Catholic psychologists who embraced this broad Thomism directed their work outwards to the world and engaged with secular versions of education. The danger was always that this Thomist philosophy could be detached from the theology of Thomas.

Today, moral theology is often reduced to social ethics and any distinct Christian conception of the virtues is increasingly replaced with a different ideological framework. Camosy (2018) has written controversially that there is 
a crisis in Catholic moral theology and identifies not proportionalism, but intersectional critical theory as the main reason:

Intersectional critical theory focuses on the interrelated systems of power that cause vulnerable populations to suffer injustice. The bad guys (powerful people and the systems that privilege them) are racist, homophobic, transphobic, ableist, neocolonial, and patriarchal. Each of these sins implies all the others, because the bad guys preside over matrices of domination in which marginal identity categories intersect with and reinforce each other. Against the bad guys, those with marginalized identities - black, LGBT, disabled, immigrant, female - find common cause, though their substantive claims may differ or contradict. For in the matrices of intersectionality, everything boils down to a struggle for power. A postmodern discourse of power, derived from a certain reading of Foucault, absorbs these theorists. Perhaps not surprisingly, power is deployed liberally in intersectional circles to discipline and punish those who do dissent or deviate from intersectional critical theory.

Many moral theologians have been concerned with a social ethics that has included their activism in areas such as immigration and refugees, race, climate change, sex and gender issues and economic justice. There is of course no definitive agreement about what intersectionality is, but it certainly points us to consider identities, social structures and power relations and focuses on our social status and how this status affects our views about character and virtues. I have written elsewhere (Arthur, 2003: 14, 15) that during the Victorian period: 'Character was viewed as a class-based concept which contained within it a judgement regarding an individual's status as much as their good conduct' and that '[f]or many, character was not an ideal, but a display of the required manners solely towards those they considered their elders and betters'. I have therefore some sympathy for intersectionality as a method. While Camosy is right to identify the illiberal tactics that some theologians use to silence and punish those who dissent from their critical theory, intersectionality can help the Christian community flourish so long as it does not become an ideology or doctrine in itself. This critical theory can help moral theologians recognise structural sin and even encourage them to advocate that we should dismantle systems of oppression. However, as a theory it is often used to deny that there can be any unified truth and those who use it claim that multiple theological perspectives ought to be used to reach a more inclusive moral theology. Intersectional advocates use terms like oppressor and victim and the danger is that it becomes a dualistic myth of good versus evil, replacing the love of God and neighbour with a hermeneutic of class prejudice and grievance. Intersectional advocates also claim that simply repeating formulas from a past age, valid to some degree though they may be, does not in fact make moral character intelligible for our post-modern and pluralistic world.

In After Virtue (1981), MacIntyre outlines a gloomy prospect for the renewal of the public moral life. He details how Western ethics has lost its foundations in Aristotelian thought and Judeo-Christian divine-law tradition. Western culture has 
emphasised the self-agency of each individual to such an extent that we have become self-interested individuals connected to each other only by freely chosen contractual relations in a state whose main function is to preserve order for private initiatives. He argues that we have no idea of what constitutes the human good and have no basis for determining common moral standards. We are effectively left isolated as individuals, and our discourse is now entirely shaped by emotivism, or as MacIntyre (1981: 11-12) says: 'all moral judgements are nothing but expressions of preferences, expressions of attitudes or feelings' and therefore cannot be true or false. Differences between moral perspectives cannot be reasoned rationally since every argument is merely assertion and counter-assertion. In response to the question of authority, we can see in MacIntyre's successive writings how rational argument within an authoritative moral tradition gains ground as the defining characteristic of any restoration of a coherent ethical life. In After Virtue, he tentatively suggests that recovery might be found in the formation of small-scale communities in which social role and ethos would be re-united and a coherent moral life therefore made possible again. It places hope in the prospect of a new St. Benedict (1981: 263). In Whose Justice (1988), he casts Thomas as the hero and suggests that a faith in the authority of the Catholic Church will strengthen any restoration of the moral life. In Three Versions (1990), he explicitly places emphasis on tradition in saying: 'Membership in a particular type of moral community, one from which dissent has been excluded, is a condition for genuinely rational enquiry and more especially for moral and theological enquiry' (1990: 60). For MacIntyre, there is no practical reasoning capacity for human beings independent of their formation and upbringing in moral traditions. We acquire moral virtues by following moral exemplars before we are able to reason about them. This has important implications for the education of character and virtues, since moral knowledge is only achieved through life experience in a tradition. The Christian nature of the thought of Thomas is acknowledged, and MacIntyre points us to a more specifically Christian ethics for the moral life.

This Christian ethics has produced at least five different, but often linked, approaches that can be briefly introduced. First, Biblical ethics is an approach that looks to the content of the Bible first and above all other authorities and applies its messages and teachings to contemporary moral situations. Second, Divine command ethics is an approach to Christian ethics that holds that whatever God commands is right and whatever he forbids is wrong. The criterion for good and evil is obedience to the commands of God (often found in the Bible). Third, Agapistic ethics is an approach that takes the Biblical command to love God and your neighbour as the central theme in ethics. Fourth, virtue ethics is an approach that places the practice of the virtues and their inculcation in the Christian community at its centre. It is more about becoming a certain kind of person than discovering the right action or rule in any given situation, as character is both formed and revealed by action. Finally, natural law ethics is an approach that holds that some moral principles are in all human beings because of the ways in which God created humans. Therefore, reflection on human nature provides the content or 
principles for much of human morality, regardless of religion or culture, for all people can discover them. In summary, our nature indicates to us what is good for us and what we ought to pursue as well as what is bad for us and what we ought to avoid. While the following chapters will refer to all five approaches, we are principally concerned with the (interconnected) final two.

\section{Suggested reading}

Brooks, D. (2015) The Road to Character, Allen Lane: London.

This is an insightful read drawing on many character traits from numerous characters in history.

Coutier, D. and Mattison, W. C. (2014) The Resurgence of Virtue in Recent Moral Theology, Journal of Moral Theology, 3: 1, 228-259.

Good introduction to how virtue has become central to moral theology.

Farley, B. W. (1995) In Praise of Virtue: An Exploration of The Biblical Virtues in a Christian Context, Grand Rapids: Eerdmans.

This is an illuminating exploration of the teachings on moral character found in the Old and New Testaments apply to Christian life.

Hauerwas, S. and Wells, S. (2011) The Blackwell Companion to Christian Ethics, Oxford: Wiley-Blackwell.

A good introduction to Christian ethics from a virtue character perspective.

Hughes, G. H. (1978) Authority in Morals: An Essay in Christian Ethics, Washington DC: Georgetown University Press.

A critical revisionist look at authority in teaching about morality.

Keenan, J. (2004) Notes on Moral Theology: Fundamental Moral Theology at the Beginning of the New Millennium: Looking Back, Looking Forward, Theological Studies, 65: 119-140.

A very good survey of moral theology.

McCormick, R. (1968) The New Morality, America, 15 June: 769-772.

An important early article on new approaches to morality.

Wright, N. T. (2010) After You Believe: Why Christian Character Matters, New York: HarperOne.

Excellent and clearly argued book on virtue and the development of Christian character.

Cessario, R. (2005) A Short History of Thomism, Washington DC: Catholic University of America.

This short text provides a historical survey in which to understand the intellectual tradition of Thomism.

\section{Questions}

Why are some people suspicious of character education?

Is morality only about the actions of individuals, or is it also a matter of the kind of community in which we live? 
If the main goal of education is to help people become 'full human persons', what does that mean to you? What does a 'full human person' look like?

What is unique about Christian character formation?

What is the role of the Christian community in formation?

What do you think the link between theology and education is?

What are the dangers of divorcing virtues from their Christian framework?

How can we answer criticisms that Christian education is a form of indoctrination?

What is the link between the role of the Church and the role of the school in education? How do these complement each other? 


\section{Chapter 2}

\section{Christian anthropology and Aristotle's character ethics}

Teachers, whether Christian or not, know that children are not little machines and education is not simply there to produce productive citizens. They know that education is a value-laden concept comprising more than skills and tests, and recognise that our education system is largely fragmented and far too specialised to the extent that it often ignores the whole person. They recognise that there is no unifying ideal or set of coherent principles that exist within modern Western public education to counter the powerful forces of the state's agencies, which all too often seek to use 'education' for their own political purposes. The modern liberal state has no particular conception of the 'Good', but rather defends the idea of 'rights' within an instrumental-orientated education and schooling. This utilitarian philosophy of education continues to dominate modern education systems, even when teachers believe it to be inadequate. Teachers, whatever their political stance, want to teach certain subjects, in a certain way, to enable students to reason, think and determine what ought to be. They want their students to think critically, to make a significant contribution to society, to be good citizens, and to embrace certain virtues like tolerance, honesty and integrity. Teachers have various moral responsibilities and clearly face moral dilemmas in teaching.

Pring (2001: 110) notes that education can be 'conceived as a moral practice concerned with values and conceptions of what it is to be human'. It is not surprising therefore, that many in educational literature claim that education is inherently a moral enterprise. Pring (2001: 106) also observes that:

Teaching, therefore, is more than a set of specific actions in which a particular person is helped to learn this or that. It is an activity in which the teacher is sharing in a moral enterprise, namely, the initiation of (usually) young people into a worthwhile way of seeing the world, of experiencing it, of relating to others in a more human and understanding way.

Education certainly seeks to make people better and is inevitably concerned with an idea of what it is to be a human being.

While many think that, in order to educate, it is important to understand what it is to be a human being, they generally are unable to come to a consensus of what this 
would entail by way of a sound philosophy of the human being. A Christian approach is not so limited, and those teaching within a Christian school can turn to Christianity to get an idea of what it is to be human. Education in character and virtues is not simply concerned with life, but ultimately with the purpose of life itself. It is concerned with human excellence, which consists of realising to the highest extent possible our distinctive capacities and how a person's dispositions, practices and ways of living must be formed in order to lead to that goal. Christian moral teaching has an interest in the interiority of the person, or the person's character, since actions are always an expression of the person. Christian character education is concerned with the formation, nurture and development of Christian virtues that ultimately constitute Christian character, and therefore it entails basic normative premises about what is good and right and the kind of dispositions education should foster, including the methods education should employ. All education is based on the expectations that students ought to learn certain things that are taught. Therefore, Christian education is an intentional process of building character through nurturing those virtues that assist us in our ultimate end - friendship with God, sanctioned in generous action and friendship to the stranger. The essence of friendship is selflessness in which we must desire the good of others. This process of forming one's own character is itself rewarding and, once developed, self-sustaining.

Contemporary education, dominated as it is with wholly instrumental goals, leaves untouched the meaning and purpose of human life or subjectivises it. Expressive individualism has come to dominate how our culture understands the purpose of life. This leads to the celebration of modern 'virtues' such as doubt, suspicion, independence, of getting in touch with our feelings. It is also rare to hear educationalists talk about ultimate purposes in life, despite character and virtues education beginning with the idea of purpose; Damon (2009) being the notable exception. Our schools, even when they commit to forming character and virtue in their students, are too often unconnected with an overarching purpose of life. They say nothing about the purpose of human life other than what each individual says it is. We need to avoid excessive individualism, which modern education sometimes promotes. Without sustained attention to a clear understanding of the common good it is difficult to achieve the larger sense of shared purpose in education. Character should not be seen as something private and simply a matter of competence. Education cannot be restricted to its utility value, reduced to the transfer of consumer goods - a product focused narrowly on skills, capacities and competencies. Despite a school's published citizenship, social, emotional or personal development programme 'aims', such initiatives are means not ends. These schools can lack a telos, or end, or destination for life because modern secular ethical theories of character fail to provide a complete picture of human moral experience. Modern conceptions of the human being are reductionist and rely on measurable and observable data, which cannot answer fundamental questions about the nature of the human person.

In contrast, an Aristotelian-Thomist teleological model offers a philosophy of education based on an overarching conception of the nature and purpose of human life. In addition, it provides a comprehensive analysis of character virtues, 
including the definition of the virtues and an examination of their nature. It provides a serious adaptation of an Aristotelian framework for moral character virtues, in which the goals of education are to facilitate the human telos, the purpose of human being. For Aristotle, the telos of a human being is to live a life worth living. A life worth living is living a good life, which is a life lived according to the virtues. The grand Christian narrative in this scheme is that we are created by God to enjoy eternal life, and therefore traditionally the goal of Catholic education was a preparation for death. Today we would say that the student is prepared for life here and hereafter, and this could be said to be the Christian teleology of education. Most Christian schools do not define themselves in such uncompromising terms, but rather offer goals that are more benign. Even if we settle on an Aristotelian-Thomist-inspired approach, we also need to recognise that there are diverse accounts and reconstructions of this.

There are many ways to introduce and understand Christian ideas of virtue and character, but this text employs a largely Aristotelian-Thomist framework to avoid the tendency to switch between different moral theories in order to justify particular moral choices. An Aristotelian-Thomist framework for a virtuous life uses our reason and the Christian sources of morality to provide a largely normative, corrective and prescriptive moral approach. There are two common, but often polarised and hence problematic, positions on moral decision-making that can be identified in the literature. At one end there is a monistic view, which believes that there is only one single position on each issue, e.g., abortion, euthanasia and murder are always wrong irrespective of the social and cultural circumstances in which they occur. This position is contrary to both Aristotle and Aquinas, and contrary to the work of Christian casuistry. While there are absolute prohibitions, neither Aristotle nor Aquinas held that there are absolute positive requirements keyed to kinds of act. There is usually more than one good thing that can be done in any particular set of circumstances. At the other end there is a pluralist perspective that believes in a wide diversity of positions, i.e., Christians can have any view on any position, and each is worthy of respect. It is a perspective which believes that individuals or Churches can advocate, on some issues, a position opposite to traditional Christian teaching, e.g., legalised abortion and euthanasia can be supported. Yet this is a false dichotomy. There is space for seeking discernment and there are absolute prohibitions, which, on their own, are inadequate to supply a complete moral code. Knowing all the things that I must never do is not enough to show me what I ought to do in any difficult situation.

In a particular Christian monistic view, definite answers are usually given because those who adhere to this approach believe that it is based on a coherent Christian framework that has an underlying moral principle to justify the answers offered. There is effectively one way for deciding moral correctness because God has commanded us to follow his precepts, say, for example, in the ethical precepts of the Bible. In contrast, the pluralist view postulates that there can be no right answers, and this view appeals to the modern mind-set, attracted as it is to the idea that morality is so complicated that no single approach will do. Strangely, both a monistic and 
pluralistic view can be absolutist in the sense that they often claim that their moral conclusions are right. Many secular people are probably ethical pluralists, but many still lean towards, and hope for, a monistic view. This is because they want decisionmaking to be less complicated and less frustrating where a pluralist approach can be subjective, inconsistent and wholly dependent on one's self interests. Morality for Christians, on the other hand, cannot simply be the product of cultural practice or social convention that changes according to time and place, otherwise we can end up with secularised versions of Christian morality. New knowledge will improve our understanding of certain issues, but prohibitions on murder, for example, remain. Pluralism can lead to moral viewpoints that are equally right and equally wrong, or result in situations where if the majority says that something is acceptable, then it is, in the sense that it is impossible for the majority to make ethical errors. A pluralist view has certain internal contradictions, and principles often overlap with each other. As Callicutt (1990: 115) says, we cannot be utilitarians one moment and Aristotelians the next, in the same way we cannot allow consequentialism to serve for some moral decisions and Aristotelianism for others. He argues that we need one approach because moral pluralism is simply playing 'metaphysical musical chairs'.

Christian education in character and virtues requires an uncompromising notion of what the end of education is, and this requires us to seek this notion in a Christian anthropology. The way to construct a philosophy of life for education is to have a clear idea of what human beings are. In the Christian sense, this is inseparable from God's active relation to human beings, such that their character and virtues are always dependent upon God. In this relationship with God, we have a voice and we are 'co-creators' in building character virtues. Christian wisdom is therefore more than secular wisdom as it includes Christian theology. This is why the Christian Scripture is the first place to which the Christian educator must turn.

\section{Scripture and character}

In Christianity, the primary source for understanding character virtues is found in the teachings of Jesus in the New Testament. Jesus stresses the centrality of the virtues of justice and mercy over the old Jewish laws with their emphasis on a ritualistic ethics of purity and cult offerings (Leviticus and Deuteronomy). Jesus understood the Mosaic Law (Matthew 5-7) as giving priority to the good intentions of the human agent, rather than simply following rules. The key virtue is named as love (1 John 4, 9), which is to be directed to the needs of neighbours, the poor and strangers. Hauerwas (1981: 66) argues that the Bible and the Christian community that it shaped provide the context for valuing and acting upon Scripture's moral guidelines. As he writes: 'The moral use of Scripture, therefore, lies precisely in the power to help us remember the stories of God for the continued guidance of our community and of individual lives.' In this way, the Christian's character is shaped by the dynamic Christian community, rather than following laws or rules alone. Rules are generally not derived from some conception of the human good, and 
they are only the basis of moral decision-making to the extent that they represent consensus about what is considered necessary for societal functioning. Rules help to articulate and give guidance to the fundamental inclination that human beings have to the good. Scripture informs moral decisions, and the virtues that are constitutive of Christian character speak of the communal call of discipleship. A Christian disciple is, by definition, one who follows Christ and reads the Scriptures to learn the ways in which Christ lived by observing his virtues. Consequently, having to make a decision is less urgent for someone who lives the Christian life. Harrington and Keenan (2002: 197) are clear that the virtue language naturally arises from Scripture and that these distinctly Christian virtues qualify character. They say a normative description of the virtues is always presented and that, through a deeper relationship with God, we are transformed into God's people. We grow our Christ-like character through increasing in these Biblical virtues and becoming the servant of all. These moral guidelines need to be practised as an expression of the Christian faith, and through this practice they produce virtues that strengthen our Christian character and enable us to carry out good works joyfully for God's glory.

There are a number of classic examples of moral teaching contained in the New Testament. The Sermon on the Mount in Matthew's Gospel stands out immediately as offering us a description of the 'ways of wisdom that lead to holiness and perfection through living the virtues and the precepts' (Pinckaers, 2001: 8). This sermon relates more to the spiritual life of the Christian rather than to the moral virtues, but it places moral obligations upon us. Pinckaers calls Jesus's sermon the 'charter of the Christian life', since it sets out a way of life that leads to our happiness by being formed in the goodness of God. In these Beatitudes, Jesus promises happiness to the lowly and humble, to those who hunger for holiness more than for power or wealth, to those generous with mercy and who are reluctant to condemn, and to peacemakers who will suffer violence rather than inflict it. These are the virtues and attributes that constitute happiness for the Christian and, like all of the virtues, they need to be practised. In a series of key texts, St. Paul, particularly in the Letter to the Romans (12-15), exhorts that we should seek what is humble, overcome evil with good, love our neighbours, show generosity and charity to all, and recommends many other virtues. He says:

Let love be sincere, hate what is evil, hold fast to what is good; love one another with fraternal affection; anticipate one another in showing honour. Do not grow slack in zeal, be fervent in the Spirit, serve the Lord. Rejoice in hope, be patient in affliction, persevere in prayer. Contribute to the needs of the saints, practice hospitality.

(Romans 12: 9-13)

These virtues are part of what is normally called the 'fruits of the Spirit' (see Galatians 5: 22-23) and St. Paul presents the Christian life as the pursuit of Godly virtues, which abound in his writings and those of St. Peter and St. James (see Ephesians 4: 2- 
3; Philippians 4: 8-9; Colossians 3: 12-14; James 3: 14-17; and Peter 1: 5-7). The virtues in the New Testament reflect the perfect character of God; for the Christian, their cause is the Holy Spirit, their goal is love, with Christ as their model.

The Old and New Testaments are full of attempts to arrive at wisdom, and the telos of Christian education is to attain this ultimate state. Christians believe in a personal God and have a distinctive belief in the Incarnation - 'the Word became Flesh, and dwelt among us'. Christianity also understands wisdom as one of the names for Christ (Sophia) so that philosophy, as the love of wisdom, is understood as the love of Christ. As Tom Wright (2010: 257), a New Testament scholar, says, the Christian virtues are based on the answer to the question 'How shall we live?' He provides, from his extensive study of the New Testament, a clear list of virtues or character traits generated from the life, vision, achievements, death and resurrection of Jesus himself. The Christian must rely on the transforming power of grace for virtuous character. Christian ethics therefore seeks a relationship with a living God whose will for each of us has to be discovered through faith. Consequently, theology is the basis for Christian formation, and this theology needs to be in evidence in the educational philosophy, the pedagogy and the curriculum of any character education initiative. This formation is the deliberate divine and human effort to acquire the virtues that are consistent with the Christian faith.

As we have seen, Christians are called by God 'to be conformed to the image of his Son' (Romans 8:29-30), to 'put on Christ', to 'follow Christ' and to 'be transformed into the likeness of Christ'. Christ is 'the way, and the truth and the life' (John 14: 6). This is a process of character formation, which means that to 'act like Christ' requires conformity to both revealed law and natural law. The former is deduced from Scripture and Tradition, while the latter is reasoned from universal principles that are accessible to all through the proper use of reason and insight. They include: (a) knowledge of moral goodness, (b) a desire to be good and do the good, and to avoid what is perceived as evil, (c) a well-formed conscience to guide, to judge and create a sense of obligation to execute the right and the good for all, (d) an array of firmly established habits of virtuous behaviours that evoke good character and, finally, (e) an orientation to will the good in others and to seek union with God. It is not sufficient to do God's will, we must also 'will' to do it: a combination of a life of excellent rational activity (Aristotelianism) and reason looking to God for direction (Christianity). This means the Christian needs to be realistic, seeing things as they are, but above all using the Christian sources of moral decision-making (the authority contained in scripture, tradition, reason and experience) as the basis for deriving life-enhancing ethical guidelines.

\section{The early Christian fathers and character}

The early Christians distanced themselves from the surrounding culture, but not from the idea of human nature. Nevertheless, as it expanded in Europe, Christianity moved towards an ethics of duty rather than virtue, but a concern for character and the character dispositions which are commonly called virtues did not disappear. 
Aristotle's ideas became more prominent in the thirteenth century with their re-discovery, but they confronted Christians with a challenge - could these pagan ideas of human nature be integrated with a Christian theology of grace? The development of character virtues was sometimes seen as a concept of self-mastery or improvement that was in tension with the Christian ethics of self-denial and sacrifice. Thomas looked for a synthesis, but one in which Aristotelian concepts were subordinated to an overall Christian vision and framework. The natural cardinal virtues of the here and now were seen as preparing the way for the theological virtues of faith, hope and love. In Christianity, there is no escaping the idea of virtue, since a life of virtue is part of the Christian life. As Wright (2010: 35) says: 'Jesus and his followers are offering the three-dimensional model toward which Aristotle's two-dimensional one points.' Aristotle only glimpses the true goal of human flourishing, but Jesus, Paul and the early Christians have a vision which is larger and richer. Wright (2010: 70) goes on to say that Christian virtue is not about you, your happiness, your fulfilment and your self-improvement, but rather it is about God, God's Kingdom and your discovery of a genuine human existence. He says: 'Aristotle's vision of the virtuous person always tended to be that of the "hero" - the moral giant striding through the world doing great deeds and gaining applause' (2018: 70). The Christian vision highlights the loving, generous character who does not draw attention to themselves - we are not at the centre of the picture. Wright seems to imply that Aristotle's theory is about egoistic personal well-being only, rather than communal well-being. The authentic Christian message is about our real happiness in this life, as well as promoting God's Kingdom - they are not mutually exclusive as Wright seems to suggest.

Some Christian authors, such as Eusebius of Caesarea, saw Greek philosophy as a preparatio evangelica (a preparation for the Gospel). One reason for this was that the authors of the pagan literature believed three things (Anton, 2018: 94). First, that wisdom is not solely a human characteristic, but rather belongs to the divine. Second, that human wisdom consists in participating in the divine wisdom - it consists in seeing the world as the gods see it and responding accordingly. Third, that to have such perception of the Cosmos requires appropriate moral habituation, so wisdom cannot be gained through purely intellectual pursuit but requires a broad development of character. For the Greeks, the goal of ethics was virtue or virtuous character, and its purpose was to teach us how to be, rather than teach us how to act. Aristotle himself thought that Sophia (Wisdom) was the highest form of truth, which aided contemplation of the eternal truths - this appears to be on the path to mysticism. He did have some conception of an ultimate reality and some good beyond the human good, but Aristotle's ultimate reality did not possess any character attributes that might enable imitation for ordinary citizens. He may have had a sense or intimation of the ultimate good but could not tell us how to reach it. The standard Greek view was that the purpose of education/culture was to form character through the cultivation or habituation of virtue. The intended moral messages in Greek culture were largely uniform, with common moral norms and consistent examples of moral behaviour set by the whole community in their roles, in entertainment, in ritual, and so on (see Barrow, 2007: 81, and Arthur, 2020). 
The early Fathers, when they engaged with Greek philosophical ideas about character and virtues, were already rooted in Scripture. While Plato, Aristotle and Stoicism influenced early Christian thought, Wogaman (2011: 23) reminds us that this should not be regarded as a departure from the legacy of Scripture. In the second century of the Roman Empire, Clement played an important part in developing a Christian education within a dominant non-Christian culture. Education at this time was largely experienced as a training in skills needed to function in society, but it also conveyed a pagan worldview. Clement, as a Christian thinker, used a Greek philosophical framework in his educational proposals, which sometimes caused him to be seen as suspect by the Christian community. Nevertheless, he did not see education as necessary for or the cause of salvation. Instead, he saw education as a gift of God, and something that is a good in this life. The virtues, he believed, were necessary for growth in character, which he saw as the primary goal of education. In his work Paidagogos or The Instructor, Clement outlines how to live as a Christian by focusing on character formation in which the cultivation of the virtues is seen as more important than knowledge. He saw no necessary conflict between faith and reason and used Greek philosophy to understand the Christian faith through his emphasis on the use of 'reasoning' (Wogaman, 2011: 40). Clement was the first Church Father to begin a serious formulation of a theory of Christian education, and he was followed by Origen who further developed his ideas.

Early Christians understood the moral life as a matter of formation in the virtues by seeing and imitating moral exemplars, such as Christ, the saints, parents and teachers, as well as ordinary Christians. They conceived of ethics as integral to the whole of the Christian religion, and they were influenced by a number of sources and pressures. For example, they were indebted to the Hebrew Scriptures, but interpreted in the light of Christ in the New Testament. They also were indebted to the ethical thinking on Stoicism and Platonism. This background set the agenda for Augustine, who in turn set the agenda for Thomas. In particular, the increasing emphasis on right intentions and motives comes from Augustine's idea of the will as the seat of morality (see Bejczy and Newhauser, 2005: 2). By the twelfth century, moral thought had become much more systematic through a greater focus on Aristotle, which influenced how character was understood and formed.

In addition, the Jewish literature had also found a consensus in the classical scholars since much of what was said could already be found in the Jewish wisdom literature that greatly influenced the development of early Christianity. The Greek moral discourse was clearly prevalent at the time of the early Christian Fathers. However, the Christian God was totally different from the pagan gods and demanded unconditional faith - something that was unthinkable for the Greeks. Christians had different ideas about the virtue necessary for wisdom. Nevertheless, Wright (2010: 70) insists that Aristotle points us in the right direction. Virtues are usually divided into two groups in the Christian tradition - theological virtues: faith, hope, love; and cardinal virtues: justice, prudence, temperance and fortitude. The first group concern themselves directly with God, while the second group apply to Christians and non-Christians alike. However, for the Christian, the 
cardinal virtues are only understood and lived through God's grace, which means we can say that there is also a group of virtues that we can call the infused cardinal virtues. The Christian faith matters for how we live, and the cardinal virtues, which are mentioned in Scripture (Wisdom 8.7), are transformed by God's grace. This grace enhances our natural capacities so that we deal with the concerns of life in a way that is informed by our supernatural end. The cardinal virtues in Christian writing are derived from the Pauline literature (1 Corinthians 13:13), which gives precedence to the virtue of charity. Porter (2001: 103) explains the roles of the cardinal virtues in this way:

Prudence or practical wisdom ... enables the agent to choose in accordance with the overall conception of goodness; justice orients the will towards the common good; courage shapes the irascible passions in such a way as to resist obstacles to attaining what is truly good; and temperance shapes the passions of desire in such a way that the agent desires what is truly in accordance with the overall good.

\section{Aristotle and Thomas}

Aristotle's philosophical ideas exerted huge influence on the moral systems developed by many of the greatest Christian minds in the Western tradition, including Thomas, who was part of the first generation of scholars to examine Aristotelian character virtues. There are many similarities with Aristotle in the approach adopted by Thomas, but the differences are just as important. Thomas uses many different vocabularies because he saw human actions as both multiple and particular, and the intentions for these acts he saw as many and complex. He uses the terminologies found in scripture, Aristotle, Plato, the Stoics, Gregory, Augustine, Bede and many others. Many who discuss Thomas's ethics usually understand it as largely Aristotelian in origin, albeit with some differences attributed to their individual worldviews. Aristotle's culture is Greek and pagan even if Aristotle himself was a deist, while Thomas's culture is Christian, founded on the Trinity of persons that is God. Ralph Mclnerny (1993: 23-24) comments on what he views as the Aristotelianism of Aquinas's ethics in the Summa Theologiae: 'The dominant voice in these questions is that of Aristotle .... It is fair to say that these discussions would have been unthinkable apart from the influence of Aristotle, particularly, though by no means exclusively, of his Nicomachean Ethics.' Anthony Kenny (1999) explains Thomas's attempt to knit scripture into his discussion of ethics by saying:

The endeavour to bring together the evangelical and the Nicomachean texts can hardly be regarded as successful .... What is remarkable about this rapprochement is not that it is done successfully but that it is done at all. Moreover, it is noteworthy that the Christian texts are distorted to fit the Aristotelian context, rather than the other way around. 
Thomas's ethics is often viewed as a kind of virtue ethics, centred around the cardinal virtues that Christianity appropriated largely from the Greeks. In contrast to many other academics, however, Jean Porter (2005) insists that there is 'a ... tendency among Aquinas scholars, ... misleading and ... prevalent ... to read Aquinas as if he not only baptized Aristotle, but is himself little more than Aristotle baptized'. In other words, Thomas's ethics is not a Christianised Aristotelianism, but rather Thomas using Aristotle as the servant of his thinking. For Thomas, no secular or manmade happiness, like Aristotelian eudaemonist virtue, was sufficient. While Thomas's works used the rich moral vocabulary of Aristotle, ultimately, he altered the understanding of Aristotelian ethics.

The ethics of Thomas have a theological as well as a philosophical dimension. In terms of moral philosophy, Thomas's ethics can be read as a version of Aristotelian ethics in that knowledge of how we ought to act is independent of religious beliefs. However, it is wrong to therefore conclude that all Thomas is doing is adding Aristotle's virtues to religious faith, hope and love. Principe (1994: 85-89) observed of Thomas:

Like his teacher Albert, he saw no opposition between nature and grace or between truths discovered by reason and those revealed by God. It cannot be stressed too much ... that what Thomas intended to be was always primarily a theologian.

Essentially, the use of philosophy does not alter the basic theological intention of Thomas, as he wrote: 'grace does not destroy nature, but perfects it' (ST I, a. 1.8, ad 2). As O’Meara (1997) says:

Catholicism distinguishes between philosophy and theology, between the divine gift of being and that of grace. A moral theory is not Christian because an Aristotelian philosophy concludes with passages from the Bible or with virtues exemplified in Jesus, or because it exalts charity. It is Christian because it relates the Incarnation to human life.

The idea that our natural human life is a life exclusively of the world is rejected by Thomas since our supernatural life begins not with death, but with baptism. Thomas builds on the thoughts and works of the other great giant of Christian thought, St. Augustine of Hippo, whose knowledge of the works of Aristotle was limited and indirect. Plato's thinking had already begun to play a role in influencing the Christian intellectual tradition prior to Augustine (see Topping, 2012), and, while Augustine was generally hostile to some aspects of pagan thought, he himself was formed by a classical education, in which Plato was certainly a major influence. Plato's ethical framework for the virtuous life and its implications for education was broadly in line with Aristotle, his student, and Augustine did not hesitate to seek what was true and useful from this pagan tradition: Augustine was also indebted to Aristotle's conception of the good life (Miller, 2012: 73) in that 
Augustine was similarly concerned with what good we should want to make us happy as well as how to obtain this good in practice.

\section{Augustine}

Thomas follows Augustine in much of what he said about ethics, including that human beings are composed of body and soul and are rational. Augustine, in turn, was influenced by Plato's analysis, that as human beings we are endowed with a unique kind of reasoning capacity for understanding that which is good. As Barrow (2007: 76) says, Augustine believed, following Plato, that: 'The educated person should have an understanding of the good, be guided and inspired by it, and seek to act according to it.' Plato was an early advocate of the teleological approach to virtue - that is, that virtues are defined in terms of functions and ends. Virtues are qualities of excellence that help human beings rule themselves well, deliberate better and thereby live well. Augustine clearly accepted the classical view that to possess the virtues is to have human excellence and that the virtues are constitutive of being a good person. He believed that a virtuous character develops out of the reflective performance of virtuous acts. Thomas affirms Augustine's definition of a virtue - virtue is a good quality of the mind by which one lives righteously, of which no one can make bad use, and through which God works in us without us. Thomas also accepts Augustine's rejection of determinism - the view that human beings are fully determined by their physical and biological natures to act in particular ways. Yet, whereas Augustine saw human beings as created in the image of God to be free to make choices and bring about change in the world, he taught that free will was limited - constrained by the physical and moral laws limiting our freedom. These moral laws help us live well, and, if we follow God's will, then God is favourably inclined towards us. Augustine also taught that we need to cooperate with God if we are to gain happiness and that living well is none other than doing what God wills. We need to know and understand the moral law, and we can only be free if we genuinely know and understand rather than simply believe. Life is the quest for truth, and Augustine wrote that if we accept God's moral laws as a guide for our lives, then we can gain happiness.

The virtues, for Augustine, lead us to happiness and must penetrate the core of our being. The virtues help us to have balance in our lives, and the good is the pursuit of virtue. The formation of human beings in virtue is the aim of education, but those virtues must be grounded in the Christian faith. As Augustine said: 'Virtue is a good spiritual quality, by which we live rightly, and by which no one can put to bad use' (De Libero Arbitrio Bk II, c19). The idea of 'quality' meant habit in this understanding. Students are not to learn what the teacher thinks, but learn rather how to discern; to know and understand what they come to believe. In other words, to discern whether truth has been stated. For Augustine, the end of our journey is life with God - at which point we are returned to God. The supreme good is therefore eternal life and for Augustine: we cannot reach God on our own for we are entirely dependent on God's grace. Thus, we must be 
receptive to God in order for us to be helped in the practice of a life of virtue so that good is done and pursued while evil is to be avoided. Augustine sees the virtues as manifestations of love, and in On the Morals of the Catholic Church (15: 25, cited in Snow, 2018: 284-285) when he writes:

I hold that virtue is nothing than the perfect love of God. Now when it is said that virtue has a fourfold division [cardinal virtues], as I understand it, this is said in accordance with the various movements of love .... We may, therefore, define these virtues as follows: temperance is love preserving itself entire and incorrupt for God; courage is love readily bearing all things for the sake of God; justice is love only serving God, and therefore ruling well everything else that is subject to the human person; prudence is love discerning well between what helps it toward God and what it hinders.

These cardinal virtues lead to the higher love of God. For Augustine, a virtue becomes a vice without reference to God, but it is still possible to acquire virtues that contribute to the common good, but do not contribute to salvation.

It is often said that Augustine stands on the shoulders of Plato, while Thomas stands on the shoulders of Augustine. This is relatively easy to demonstrate in Thomas's Summa Theologiae, in which Thomas cites Augustine no fewer than 3,156 times, compared with 2,095 times for Aristotle. Thomas also cites the other Church Fathers 3,131 times. Nevertheless, Thomas modifies Augustine's view of the world as entirely sin-laden and disordered. Augustine also thought that the idea of pagan virtues was self-contradictory, while Thomas thought they were true human virtues, albeit imperfect. Thomas sees the world in more positive terms as rational, humane and ordered. He also has a more positive view of searching for earthly happiness, so long as it is subordinated to the final end of life with God. While the authors of the New Testament rarely mention virtue, the substance of the concept pervades their moral teaching. This is why the Church's earliest moral teaching has an understanding of virtue, even though the Church Fathers generally did so in the language of, and from the perspective of, Scripture. As Cahill (2002: 17) writes:

At the level of character formation, the Bible as story and narrative can engage and educate the full panoply of our moral capacities - the imagination, affections, and emotions, as well as the intellect. All of these are necessary to bring ethical theory and reasoning to the endpoint of committed action.

Cahill (2002: 10) offers a framework of biblical character ethics in which 'character' 'indicates a process of communal formation of individual identity' which 'orients Christian persons and communities around general values, principles or virtues that reflect God's self-disclosure in Christ'. It is difficult to overstate the centrality of Scripture in Christian character formation or the Christian community as the location for learning, practising and interpreting Scripture for Christian living. 
Augustine, like Thomas, thereby applied Greek philosophy to Christian theology in a supportive role in the same way that St. Clement of Alexandria did in his use of Plato, maintaining Christian orthodoxy while using vocabulary and wisdom derived from Greek philosophy.

\section{Aristotle}

In exploring the Aristotelian part of the Aristotelian-Thomist framework, it is necessary to recognise at the outset that Aristotle's thought does not easily lend itself to any modern theories of moral behaviour or what social scientists call 'pro-sociality'. It is also true that virtue ethics as a field is too diverse to be defined by the term Aristotelian, as there is a multiplicity of approaches to virtue ethics. Nevertheless, modern secular thought shares with Aristotle the belief that human beings have within themselves the resources to become virtuous and lead flourishing lives. Aristotle begins his theory of ethics by stating that everything has its own goal and human beings have a telos or goal-directed activity to their humanity. This telos refers to the proper functions and ends associated with living things. Aristotle claimed that human beings possess a specific 'human function' of having a unique goal or purpose in life based on their nature. For Aristotle, all human beings seek happiness and this can be obtained through the careful use of reason and the acquisition of the virtues. According to Aristotle, 'reasoning that leads to actions must start from the assumption of some end to be realized' (Cooper, 1986: 76). Aristotle identifies at least three different understandings of happiness lived by three distinct groups in society. First, those who see happiness in pleasure and fun. Second, those who live as if happiness were honour and social recognition for their personal excellence and achievements. Third, a rare few who live as if happiness is learning and seeking wisdom - in other words philosophising. Most people are to be found in group one, a few in group two and a tiny number in group three. Aristotle does suggest a fourth group - those who are happy when they embrace wealth and money - but he rejects that this group can be genuinely happy and returns to a study of the telos of human life.

MacIntyre (1981: 52) writes that within this 'teleological scheme there is a fundamental contrast between man-as-he-happens-to-be and man-as-he-could-be-ifhe-realized-his-essential-nature'. This conception of telos is central to Aristotle's thought. He believed that our nature as human beings determines our purpose and that we are designed to be agents of goodness and virtue in order to fulfil our purpose in being good. When we are good, the telos of human life is fulfilled, and we consequently achieve happiness or human flourishing. This human flourishing is achieved by means of obtaining the virtues, normally by repetition of appropriate actions (habituation) under guidance to constitute what Aristotle called eudaimonia being well and doing well. For Aristotle, we incline towards something - 'the good is that which all things aim' - and this ultimate good is not subordinated to any other good. Aristotle's model is complex and holistic, involving interconnecting elements and human capacities that are perceptual, affective and deliberative. The flourishing life is one in which our thinking, feeling and acting conform harmoniously to the 
good. This is a high achievement, and it requires the support of a community animated by the vision of the good. It requires the process of education to initiate it and to positively contribute to this goal. It requires a foundational anthropology at its heart, but there is a tension between what we happen to be and what we could be. The telos must be specific enough to provide guidance but not too restrictive as to reduce it to only a few ways of living. Wright (2010: 28) believes that three things transform our character: (a) aiming at the right goal, (b) understanding the steps to the next goal and (c) habituating these steps, making them a matter of second nature. In Russell's (2013: 19) view, eudaimonia is 'two things at once: it is the final end for practical reasoning, and it is a good human life for the one living it'. For Aristotle, it is the final and comprehensive end of life.

Habit forming is not about mindless activities but has a broader and richer meaning within moral theology. Habits are the more enduring qualities that make us a certain sort of person. From the Latin term habitus, the words 'dispositions' and 'inclinations' capture what habit means best. Although developed or obtained through repeated actions, they should not be seen as mechanistic and nor are they unchangeable. They are developed in people who are free, can reason, and have the will to persevere. They also include intentionality since our intentional actions shape our very selves. We have the freedom to choose well, and this leads us to fulfilment or happiness. When we possess a certain habit, we are inclined to more of such actions in the future - it becomes part of who we are and we exercise these habits effortlessly, to such an extent that we feel there is something wrong when we stop exercising it. Both Aristotle and Thomas called habits our 'second nature' because habits ingrain what a person does as well as form what a person is. Habit, as a disposition, changes who we are and resides within us. Virtue is a habit too and virtues are perfecting qualities, i.e., morality is a product of nurture, not raw nature. As Sullivan (2021: 491) says: 'the more perfect a habit of virtue is, the more forcefully does it make the will tend toward the good of that virtue'. While habit is an abiding quality in a person that inclines them to act in a certain way, a virtue is a habit that inclines them to act in a good manner, both externally and intentionally. Vice is the corresponding bad habit. Having the virtues is not simply about doing good works. Habits change us, and the virtuous person does good things more frequently and consistently, without having to think too much about their actions. It is really about the selves that we sculpt - a process of becoming. Moral development or character education, for Aristotle, is a process of learning to exhibit virtues in action (see Kristjánsson, 2014). However, the virtues themselves do not always provide actual answers about what one is to do in concrete situations. Rather, it seems that they equip the person with a sense of what is 'appropriate'. Aristotle does not so much tell us what virtue is, but rather that it aims at making us good persons. There is scope to explore how virtues help us to make moral decisions, but in this text, virtues are viewed as stable dispositions for the good that orient a person to act in a certain way that is continuous through the diversity of choices they make in concrete situations. Aristotle held that every virtue is located on a spectrum that places them between states of too much and too little. He adds 
that the mean (the via media) must be determined in a way that takes into account the particular circumstances of the individual (Ethics, 1106a 36-37). Whilst he names justice, courage, temperance, magnificence, magnanimity, liberality, gentleness, prudence and wisdom as virtues, a more extended list is found in Plato's Republic and these virtues were expanded by writers such as Cicero in the Latin West, and later by Ss. Ambrose, Augustine and Thomas.

Phronesis, or practical wisdom, is essentially the union of both theory and practice, and Aristotle views it as the intellectual virtue that reigns over all the other virtues. Practical wisdom, as the integrating virtue, unifies all moral decisions into a coherent whole and arranges every decision and practice into a life of excellence (Darnell et al., 2019). Right reasons combined with the right feelings are key to Aristotle's definition of virtue. Phronesis-guided virtue includes the wisdom to know the good, the desire to achieve the good and the will to choose the good. It is a desire to see the good prevail even when no one else knows and when there is no reward for doing so. We cannot be wise without virtue. It emerges in human activity through the ability to recognise wisdom in others, which builds our moral character. Aristotle argues that good character that has been formed by a series of past decisions, begun initially by imitation, reinforced by repetition and informed by reflective reason, would choose correctly in moral decision-making. Anselm Mueller takes a simpler line, viewing phronesis as the intellectual aspect of good character generally, and the intellectual aspect of the implementation of each and every specific virtue.

Education is therefore concerned with the transition between human nature as it is and human nature as it could be. Consequently, certain actions, habits, capacities and inclinations are encouraged or discouraged because they take us away from, or towards, our telos. The virtues are essential components of the human good, and they largely constitute the telos in Aristotelian thinking. The virtues are also instruments or means to the good, but never merely instruments. They include all those states of character that influence how we act and choose and contribute to us becoming fully flourishing human beings. In this thinking, teachers are facilitators of character and human flourishing. Flourishing does not simply relate to the subjective aspect of human fulfilment, but to the meaningful realisation of life's overarching goals (Kristjánsson, 2020). Aristotle did not consider the specific virtues of the teacher mainly because teaching was not thought of as a proper task for a noble man and had, in ancient Greece, been tainted by association with the infamous sophists as private tutors. However, Christianity elevated the vocation of teaching, since Christian virtues require a robust concept of the moral exemplar to model what the virtues actually look like for students. Aristotle warns us however that the young are often controlled by their passions and only acquire the virtues through habituation, essentially by acting as if they already possess them. However, is this true virtue? Aristotle certainly thought that young children needed to gain knowledge of the good as well as enjoyment in doing the good. As Burnyeat (1980: 72) says, young children cultivate a 'general evaluative attitude which is not reducible to rules or precepts'. Children have a partial, but 
developing, reasoned conception of the good. Hull (1910: 163) helpfully notes that 'character is a life dominated by principles, as distinguished from life dominated by mere impulses from within and mere circumstances from without', reminding us that we are more than simply what happens to us and always more than rule-governed behaviour. This is why Aristotle rarely speaks of rules because to him rules are secondary to, or derived from, virtues.

Aristotle thought that the proper function of human beings was to think rationally, from which he derived the idea that the highest life available to us is one of contemplation. He clearly believed in the power of human intelligence or ability to think, which he said distinguishes us from animals. We have the capacity to think, to analyse, to make choices, and to orient our lives in one direction or the other. Aristotle (Ethics, VI, 2 (1139 a 22-26)), argues that reason and will must inform our emotions:

$[\mathrm{M}]$ oral virtue is a state of character concerned with choice, and choice is a deliberate desire, therefore both the reasoning must be true and the desire right, if the choice is to be good, and the latter must pursue just what the former asserts.

The intellectual virtues, as stated here, simply procure the capacity to realise the good. Aristotle believed that we need to work on ourselves to improve ourselves. He (Ethics, II, 6) believed that the moral life is found in 'the just means':

Virtue, then, is a state of character concerned with choice, lying in a mean i. e., the mean relative to us, this being determined by a rational principle, and by that principle by which the man of practical wisdom would determine it.

Bad behaviour is therefore an excess or defect - for example, eating too much or too little -while virtue consists in acting the right measure. There is a degree of ambiguity in saying that a person is what they choose to act upon. Aristotle was aware of this, recognising that it is possible to perform just acts and yet not be a just person. Importantly, he gave emphasis to an accountability and acceptance for one's choice and direction in life that Thomas endorsed and that we will discuss in more detail later.

\section{Aristotelian-Christian comparisons}

Despite the limitations in Aristotle's thought, there are similarities and continuities with Christian thinking on character virtues. Points of convergence for Aristotelian and Christian thinking on education might include the following claims, many of which have common-sense appeal. First, the ethics of character formation concerns the nature and purpose of human action, and human flourishing is an appropriate end of education. Humans are physical, social, rational and emotional beings distinct from other animals and therefore have a function, a purpose in a life 
lived by reason, which includes goals outside of the confines of self. As Kenny (1998: 68) notes: 'it is the worthwhileness of this end of an action which makes the actions leading to it themselves worthwhile'. Purpose, educational activity and goodness are connected. Second, the role of human agency is central to the formation of character, and therefore a person of character freely deliberates and discerns with a purpose in mind. The will has a place in human agency that is linked to practising the virtues, although in the fully virtuous person conscious acts of will are no longer required, as virtue has acquired an effortless fluency.

Third, virtues are qualities of excellence, sources of strength and energy, settled dispositions and habits, and represent a human being's capacity to act and think well in order to produce good works. Virtues are not innate, but must be acquired by practice, and they shape character. Virtues can be caught, taught and sought. Fourth, we can know the good by seeing it exercised in others, and the good is that towards which all things tend. There is a connection between living virtuously and being happy, and we need a certain degree of experience or maturity in life to successfully develop good character. You cannot be happy without being good, and the virtues are fundamental to educating for the good. Fifth, good character requires practical wisdom as the integrating virtue since it allows us to judge rightly what a situation demands from us so that we can act. You cannot be wise without moral excellence. Finally, we are shaped by profound forces; biology, social environment, history and the virtues are socially formed. A state is a society of humans sharing a common perception of what is good and just, and its purpose is to provide a good and happy life for its citizens (see Kenny, 1998: 75). It is important therefore that the virtues that are formed in citizens can be viewed as other-regarding as opposed to being overly self-centred. Community and the promotion of the common good are key elements and a realisation that we do not flourish through acquiring wealth or through consumerism. Virtues formed socially help human beings deal with changing contexts and advance the virtue of friendship. All six of these Aristotelian points found their way into a Christian philosophy and theology of character formation.

Thomas recognised that

the perfection of virtue consists chiefly in withdrawing man from undue pleasures, to which above all man is inclined, and especially the young, who are more capable of being trained. Consequently a man needs to receive this training from another, whereby to arrive at the perfection of virtue.

(ST I-II q. 95, a. 1)

Virtue, Thomas taught, ought to be acquired by means of some kind of training, and he agreed with Aristotle that the young are more capable of being trained. Both Aristotle and Thomas define virtue in terms of the life well lived, but Thomas calls this good life or human flourishing beatitude, while Aristotle calls it eudemonia. These translate into English as 'happiness', 'bliss', 'fulfilment', 'well-being' and 'flourishing'. Thomas offers a divine, 'non-fragile' happiness. For Aristotle, eudemonia is confined to this life, the here and now, and is essentially vulnerable to 'moral luck', while for the 
Christian, beatitude has two parts; one life in this world and one beyond, with both parts focused on God as the source and goal of our happiness on earth and in heaven. Imperfect happiness is the happiness all of us can experience on earth (Christian or not), but perfect happiness is only possible through the beatific vision of God that provides the complete happiness for which we long. The ultimate end for the Christian is therefore God, the supreme good, and Thomas argues that we must act voluntarily in entirely human ways to obtain this good. Aristotle divides the virtues into intellectual and moral, while Thomas sees them as intellectual, moral and theological. Both prioritise the virtues differently, but Aristotle's list of virtues appears more chaotic and arbitrary, although the meta-virtue of phronesis is meant to add a synthesising order to the chaos. However, Thomas agrees with Aristotle that life lived in accordance with reason is intrinsically happy-making. Both focus not on singular human actions in the moral life, but rather on how the person becomes good or bad. It is easy to think that Aristotle and Thomas agreed on everything; they did not. While Aristotle thought that friendship with others aided character formation, Thomas believed that character formation is primarily aided by a friendship with Christ.

There are clearly limitations and points of departure from Aristotle for Christian thinking on character formation. Aristotle's theory is 'naturalistic' and does not depend on any theological or metaphysical knowledge. His focus is on human nature and other worldly and social realities. Clearly the Christian virtues of faith, hope and love are not considered by Aristotle, while some other definitions of virtues in Aristotle are incompatible with Christianity. The worldliness of Aristotle gives his ethics a pragmatic external sense of goodness and the good life, yet the static nature of Aristotelian categories is limited - it is two-dimensionally fixed on the pattern of the good life. The Christian virtue of love of neighbour requires more than Aristotle provides. As Jean Vanier (2001: 182) points out, 'the possibility always exists for any person to awaken to a life of relationship, however minimal, provided he or she is surrounded by respect and love'. Aristotle would not have agreed, given his early-years determinism that emphasises how virtues are acquired through good upbringing only, rather than any subsequent epiphanic awakenings. Virtues are not solely a product of human agency for the Christian, and Aristotle had little time for the virtues of humility and compassion, and the desire for justice on behalf of the poor is completely lacking. While Eleos (compassion) is a fundamental virtue in Aristotle, it is limited to pain at other's undeserved suffering. He thought that pity for those that deserved their suffering was a vice. His understanding of the virtue of compassion is more circumscribed than in Christianity. In Christian thought every student has the same and infinite value irrespective of background whereas for Aristotle social hierarchy was important. Aristotle also valued human life on the basis of intellectual capacity alone, and his philosophy implies that only those who are autonomous are worthy of happiness. For the Christian, Aristotle's virtues fail to direct you to the highest goods since Aristotle places greater stress on selfsufficiency whereas Christianity does not. Self-improvement and self-mastery lead to 
the cult of self-development and express a false pride. In a Christian understanding, virtue is dependent on God for full acquisition.

In Aristotle, education is reduced to the ethical, and morality is understood only from the philosophical perspective. Character in a Christian sense is more than a moral compass focused on a life of human virtues and earthly flourishing. A Christian ethics is premised on a notion of a true human nature with a determinate human good, end or telos. Many who follow Aristotle's scheme of ethics reduce Christianity to ethics - a way of living in this world, not for the next, and so Aristotle's idea of teleology/human nature is deployed to resist any subordination to a higher end. However, Aristotle's ideas about human flourishing were not wrong, they were just incomplete. The Holy See's International Theological Commission (2009) published a paper entitled 'In Search of a Universal Ethic', which recognises that, in an era where pluralism reigns, it is not surprising 'that one witnesses today a new blossoming of virtue ethics inspired by the Aristotelian tradition'. This Thomist-inspired paper appeals to personal responsibility and individual decision-making, arguing that to seek to be free from responsibility is to cease to be free. It is also worth reminding ourselves that Hauerwas rejects the idea of moral character or the moral life represented as a series of decisions resulting from facing a series of dilemmas, as he says: 'Decision is not king' (1986: 29), and 'The moral life does not consist in making one right decision after another' (1986: 44). He believed that such thought promoted discontinuity in the moral life since decision-making ultimately depends on the narrative of the Christian community.

It is also important for Kotva (1996: 91) to remind us that we are composed of body and spirit, and that if we emphasise the body then we develop a mechanistic vision of the person, whereas if we overemphasise the spirit, then we develop the idea that we are totally free of constraints. If, in contrast, we view them in balance with each other, we naturally see both limits and freedoms. This is because the body symbolises our solidarity with the rest of creation and the ways it shapes us and the spirit symbolises that we are transcendent beings who act and share in relationships. Freedom allows us to choose and self-form to develop our character, but there is also grace, which frees us for a certain kind of life - one that exhibits service, love, peace, patience, kindness and self-control. It is often said in Catholic circles that 'freedom consists not in doing what we like, but in having the right to do what we ought'. We could argue that we are only free and exercise our free will when we know the end for which we act. Hancock (2005: 46) usefully characterises the issues explored in this chapter when he states:

The Church Fathers recognized that we could put Christian philosophy in the service of faith, all in the spirit of ... 'faith seeking understanding'. Philosophy could assist in 1) interpreting Scripture, 2) explicating articles of faith, and 3) defending the Christian faith against those who condemn it as superstitious. Philosophy's power to provide assistance has repeatedly proved itself over the centuries, culminating in the thirteenth century in a theological synthesis ... whose greatest representative was St. Thomas Aquinas. 
Thomas joins Augustine and the Church Fathers with the legacy of Aristotle. It is therefore to Thomas that we now turn, fully recognising the many issues involved in developing his thought in education, particularly those concerned with understanding his method of presentation, his terminology, and the historical setting and context of his writings.

\section{Christian anthropology and character}

In a broad sense, anthropology involves the study of human beings, and if we want to educate for character through the acquisition of the virtues, we need to understand the concept of character virtues as well as the nature of the human person. This includes both the social and narrative roles of being human - who we are individually and collectively. For the purposes of this text, it means developing a realistic model of the human person - seeing moral agents in terms of their character - entailing the capacity to choose between options and being able to do what they choose. Ultimately, a Christian anthropology is about discovering the meaning and importance of three basic Christian assertions: the human being is an image of God; Christ died for the redemption of humanity; the human being is called to a supernatural destiny of communion with God in heaven. As Gula (2003: 24) aptly notes: 'In a nutshell, morality is about what we should do because of who we are.' The use of Christian or Catholic anthropology as used in this text is not meant to be taken as asserting the definitive Catholic approach, but rather as one application of Catholic faith to understanding character and virtues.

Brugger (2009: 5) outlines the main tenets of a Catholic anthropology in developing a framework for understanding psychology that can be used as a lens for considering character virtues in education. His model of the human person is based on the Aristotelian-Thomist tradition, which he says is useful for thinking about character virtues and their role in human flourishing. He helpfully describes the human person as: (a) bodily, (b) rational, (c) volitional, (d) relational, (e) substantially one, (f) created by God in his image, ( $g$ ) weakened by sin and (h) invited to become a member of the body of Christ through baptism. These eight domains are interrelated, and, accordingly, whilst he categorises the first five as philosophical anthropology and the final three as theological anthropology, he emphasises that the theological cannot be omitted from the first four entirely. His description rests on several points. First, human beings are complex biological organisms divided into two sexes: male and female. Second, human beings have the capacity to think and are open to knowing reality and to make some order of it in their minds. We are therefore more than simply bodily beings. Third, what he calls volitional relates to our free practical deliberation, judgements, choices and it is within this domain that we shape our moral character. As he says (2009: 9):

So when we refer to 'character' our reference is to those dimensions of the self that are subject to alteration as a result of deliberate human action; said 
another way, character is the set of enduring dispositions of mind, will, and affect as shaped by our morally good and bad choices. Although many things in life are beyond one's control, reflexive character is not one of them. One's character is one's own doing, one builds it up or tears it down one choice at a time.

Fourth, relationships matter since we must be in relationship to be human. This relational domain requires the actions in the domains of reason and volition. It emphasises that these relationships within the community to which we belong are character forming because we have an appropriate dependence on others that leads to our interdependence. Through a Christian lens we are created not only to be in relationship with God, but we are also created for community; to be in relationship, mutual love, concern and respect for one another. Fifth, classical philosophy teaches that we are composed and united as body and soul. The physical body and nonphysical soul are interconnected and not separate. It is the soul that animates the body, the body being mortal and the soul immortal, and this domain leads us onto to a Christian unified conception of the human person.

The three theological domains are illuminated by the Christian faith, and they concern human beings as created, fallen and redeemed. First, every human being is created in the image and likeness of God and therefore possesses a unique dignity deserving of respect. Second, sin causes alienation from God in every human being and a certain disorder at the level of human existence that gives us the realisation that we cannot reach perfection in this life. It is sin that disrupts our relationships with one another. Third, sin can be overcome, as well as our alienation from God, through Jesus, who invites us into a relationship with God. The ability to act virtuously comes through grace, but not without effort or our participation. While we are still weakened by sin, we can be assisted and even healed by God's grace. In other words, we can potentially become holy and restore our friendship with God. Thomas defines grace as 'a light of the soul ... when a man is said to have the grace of God, there is signified something bestowed on man by God' (ST I-II, q. 110, a. 1). Grace is therefore supernatural and is greater than what human nature can accomplish by itself. The grace of God transforms a person enabling them to be good and to do the good. It moves and enables the will, enlightens and guides the intellect, so that a person may choose and enact the good. The grace of God is essential to living the moral life for the Christian.

However, we can have no preconceived blueprint of what a person ought to be, since to attempt virtue is a lifelong quest - a journey towards a notion of wholeness in which we are never completed. Because of the great diversity of visions of the good life that are embraced by people, we need a theologically informed Christian vision of character and virtues that we can explain and defend. Christian ethics in this sense is really a critical and constructive reflection on moral existence from the perspective of the Christian faith in which we articulate the moral meaning of Christian convictions. Although the vision of the good can never therefore be fixed in advance in any particular education (as students must 
be free to seek it), this does not mean that a school has to offer a thousand choices for building character. Because we are creatures composed of body and soul and made in the image and likeness of God, where God is the exemplar and humans the image, Christian education intends to make us more human by sharing in the divine life - to better us - to know the good, love the good, and to do the good. For the Christian it is not enough to simply know the good, one has to be committed to it. Therefore, when we do Christian ethics, we are doing so with a particular understanding of God, of humanity, and of the world. The different ways of looking at Christian ethics makes it complex.

Our character virtues are never simply inherited, nor do they grow on their own - they have to be formed and cultivated in communities because there are 'no persons of virtue without formed communities, no formed communities without persons of virtue' (Boland, 2007: 185). While we become a certain kind of person through our choices and actions, we also acquire the character virtues in the company of others because community is non-negotiable when it comes to our formation, since we cannot realise our potential in isolation. However, character is something that constitutes us as unique individuals - as the inner form that makes us what we are. It is our essential core, our inner reality and what we do consistently in life. It is therefore more than a collection of occasional behaviours or a set of good intentions - it is a way of being. There is circularity in this approach as character determines human action, just as human action determines character - 'no persons of virtue without formed communities, no formed communities without persons of virtue' (Boland, 2007: 185).

Pinckaers (2001: 115) defines virtue as 'a quality of heart and mind, of reason and will that disposes a person to engage in acts and works of excellence, perfect in their composition'. Virtues influence how we describe what we do, what we think we are doing, and what we think is important. The virtues shape not only one's character, but the world we see and inhabit - they determine who we are. Our character arises out of the practice of these virtues and through education helps students grow in their humanity to become good, wise and just - to flourish in life. To have virtue is to have the power, capacity and ability to achieve something. Ultimately, Christian virtue is not what humans achieve, but is rather what God enables to grow within us. Pinckaers (2005: 15) develops a virtue-orientated morality rooted in the moral theory of Thomas in which 'the virtues form an organism whose head is constituted by theological virtues. These animate and inspire the moral virtues from within, to such an extent that they transform the measure of the moral virtues'. It is important to state that Pinckaers is central to any consideration of Christian virtues as his influential book, The Sources of Christian Ethics, 'sets the trajectory for at least a generation of Catholic moral theologians, a trajectory in which virtue plays a major role' (see Coutier and Mattison, 2014: 238 and Titus, 2012).

A virtue approach to the moral life will emphasise virtues and the role of the agent and their character in moral decision-making and evaluation. It understands moral virtues as virtues of character and that having a good character is necessary to 
be moral. A virtue is therefore an excellence of character, and so in order to be a good person we must develop our character in the right way. We must be taught to practise actions in a virtuous manner, so that our actions over time will form our character. Our character is formed by what virtues we possess, and character itself has a developing quality about it. It is also the case that the things we do and the things that happen to us forms our character and hence our future actions, which are important because they display our values and commitments. Those who model the virtues are our teachers as they help us understand virtue, help us to describe virtue, and even help us to define virtue in practice. Above all, it is important to realise that this virtue approach to character construction has much more to do with the trajectory of life: who we are now and who we are becoming. Becoming in this sense means being in transit, moving from one condition in life to another. We need to identify these character virtues to set ourselves personal goals, but these virtues are not simply what we acquire in life, they are what we pursue. We are not born with a set of character virtues; we acquire them through a long process that includes formal education. At first sight this appears individualistic, but we come into existence embedded in a family and a society which may or may not - form us well as we gradually come to 'own' our 'life story' and become able to act according to and with what 'nature' and 'nurture' have given.

\section{Suggested reading}

Hadot. P. (1995) Philosophy as a Way of Life, Oxford: Blackwell.

This book illustrates how philosophy can be seen as a way of seeing and being in the world.

Hauerwas, S. (1985) Character and the Christian Life, Notre Dame: Notre Dame University Press.

An excellent examination of how our moral life is not composed of beliefs plus decisions; our moral life is the process in which our convictions form our character to be truthful.

Spohn, W. C. (1992) The Return of Virtue Ethics, Theological Studies, 53: 1, 60-75.

A look at how virtue ethics has become more prominent in moral theology.

Miller. J. (2012) The Reception of Aristotle's Ethics, Cambridge: Cambridge University Press.

An exploration of how Aristotle's ethics have been variously received in different historical periods.

Varnier, J. (2001) Made for Happiness: Discovering the Meaning of Life with Aristotle, London: Darton Longman Todd.

An interesting insight into Aristotle's ethics from a Christian perspective.

Veatch, H. (2003) Rational Man: A Modern Interpretation of Aristotelian Ethics, Carmel, IN: Liberty Fund.

Written originally in 1970 , this new version is a popular presentation of Aristotelian ethics for the intelligent layperson. 
Vitz, P. C., Nordling, W.J., and Titus, C.S. (eds.) (2020) A Catholic Christian Meta-Model of the Person: Integration with Psychology and Mental Health Practice, Sterling, VA: Divine Mercy University Press.

This work draws from Aristotle and Aquinas, conceptualising a Catholic Christian framework for application in mental health practice, as well as in education and personal formation.

\section{Questions}

What is your idea of the educated person?

Can an ethics built on a Greek foundation be Christian?

Why do people not necessarily become more virtuous with age?

What are the limits of reason?

What is your understanding of how virtues develop in people?

How could a Christian education be considered broader than an instrumental one?

What does Christianity add to an Aristotelian understanding of virtue?

What are the similarities and differences between a Thomist understanding of virtue and an Aristotelian understanding?

How does Thomas build on and depart from an Augustinian understanding of virtue?

Aristotle recognises different understandings of happiness. Do you recognise these understandings in society today? How do they differ from a Christian understanding?

What is the role of habits in virtue development?

How does an understanding of body and spirit affect the idea of virtue? 


\section{Chapter 3}

\section{Thomism and Christian moral character}

Thomas Aquinas was born in Italy in 1225 and received his early education at the Benedictine monastery of Monte Cassino. He then studied philosophy and theology at the University of Naples before entering the Dominican Order and being ordained a priest. The Dominican Order was devoted to teaching and preaching. He subsequently completed his studies at the University of Paris. Thomas was a theologian and teacher who significantly influenced Western thought with his two great written works: Summa Contra Gentiles and the Summa Theologiae. The latter he wrote out of his dissatisfaction with the teaching methods of the time. The Summa Theologiae showed the importance of virtue and how Christ leads us to virtue, highlighting Christ as exemplar and teacher. As a theologian, he taught Scripture in his classes and, while rooted in the authority of Scripture, also taught the need to read Scripture guided by the tradition of the Church, which specifically included the Church Fathers. His theology was reliant on the Church Fathers and he used them along with Scripture as essential sources in his approach to considering the purpose, goal and end of all that he deliberated upon. Yet in order to explain the virtues, he drew on Aristotle. Many say that his main achievement was to make the ethical works of Aristotle acceptable to Christian Europe, but, in teaching about character virtues, he always gives primacy to Christ. While Thomas was an Aristotelian, he was above all a Christian. His theological and philosophical legacy is still unfolding today.

The writings of Thomas are a striking work of synthesis that attempt to reconcile faith and reason in a comprehensive vision. Thomas attempted to explain how everything fits together and had an openness to truth wherever it is found. He sought to make sense of the world by articulating the relationship between the divine and the human by stressing unity, integration and wholeness. Chesterton (1933) emphasised the considerable optimism that is to be found in the philosophy of Thomas, particularly concerning our fallen condition in the natural world. He showed how Thomas taught that our natural reason grasps many truths about the world in which we live. Life in this world has the potential to be good because all human beings participate in God's being. Indeed, Chesterton points out that Thomas teaches that, in the world in which we live, God benevolently ordained that we have a positive purpose which we can discern and enact. God reveals himself in nature, history, culture, society and in human existence. Life is not simply a mere 
means to reach an end - if that were the case then life would have merely instrumental value. Thomas is positive about human nature and, despite the consequence of the Fall, is not dismissive of people's inner strength to overcome their weaknesses and to strive for a better life. Therefore, life is not to be viewed merely as a waiting room for heaven. Thomas understood life as full participation in the life of culture, the arts, the sciences, in making the laws and all as essential to living the life in Jesus Christ serving God. You could say that such participation is about transforming culture and society, 'For everything created by God is good, and nothing is to be rejected if it is received in thanksgiving' (1 Timothy 4. 4). Thomas is optimistic about human nature because every human being has the capacity within them to change through grace, to turn from evil and to look for the good. This capacity, according to Thomas, is freedom, which is the means by which to reach human excellence and to fulfil our human destiny by a life of virtue. Thus, even the weakest person can become better, if they decide to lead their life to the good. Thomas clearly believed in the formation of the character virtues.

\section{The vision of Thomas}

In the Thomist analysis, the central virtues grow in number from four to seven and have had immense influence. Thomas unites the Christian heritage (based on the Gospel and developed by the Fathers of the Church) and human wisdom (Aristotle being considered the best witness of this wisdom). In Thomas, character formation in virtue is ultimately conformity to Christ crucified, stating: 'in the cross is the perfection of the law and the whole art of living well' (Bauerschmidt, 2013: 263). Aristotle would have rejected completely that the art of living well could be summed up in an instrument of death and torture. This is why Thomism is such a radical transformation of Aristotelian thought in its synthesis of Aristotelian philosophy with Christian beliefs and theology. Thomas takes Aristotle to a new level, relying not on willpower or determination, but rather on the transforming power of God's grace. Thomas saw Aristotle's ideal of happiness in this world as imperfect happiness; an indication that true and perfect happiness is only enjoyed in the afterlife. The highest aim of human nature is therefore not happiness in this life, but full happiness that is realised only after death. This is why, traditionally, some Catholic philosophers of education spoke about the goals of education being a preparation for life after death, or even death itself.

For Thomas, character is firmly grounded in a Christian theology and begins with a study of Scripture, the biblical patterns of good practice, the key biblical terms, as well as biblical heroes and stories in the Old and New Testaments. He recognises that character and virtues are not the main themes of the New Testament, which is why he looks to the experience of the Church and employs reason in order to produce a theological vision of character and virtue. This vision involves an examination of how human agency and divine grace interact. Thomas saw the pagan virtues of Aristotle as imperfect, but capable of being directed beyond themselves to our final end, only completed in our need for God. Yet 
whilst human nature has the capacity to acquire the natural cardinal virtues without the benefit of Christian revelation, the importance of virtue as an educational aim was advocated by the Church Fathers, by Augustine, and by Thomas. This education was directed at leading a life in co-operation with God's will and in which human fulfilment is recognised as contributing to the common good.

Despite some changes in meaning, Thomas uses Aristotle's vocabulary as well as many of his distinctions. Aristotle and Thomas are both realists who believe that we have reliable access to knowledge through empirical observation and experience of the world. They both take seriously what our senses show us, and they emphasise the importance of context for experience and deliberation. They share a common concern for rationality, in the sense that the world can be understood as rational - it is not possible to be really good without wisdom or really wise without the moral virtues. Wisdom is also not gained in isolation from the other virtues, which they agree must be acquired through gradual habituation. How we know truth, how we communicate truth, and how concerns for truth lead to the promotion of the good itself mean that truth and goodness can never be separated. Knowing something is not simply an intellectual exercise but always involves the moral and theological. As Boland (2007: 60) says: 'For Aquinas, the activities of being what is true and seeking what is good are what it means to be capable of understanding, decision, and initiative.' We are engaged by nature to know truth, and education needs to be related to the end of the human being. In order to lead a life worth living, Thomas believed knowledge of the end was necessary and that this knowledge was the basis for right acts. The learner is not passive in all this, and the teacher can be the secondary cause of another's knowledge. Acting well for some intended purpose emphasises the teleological orientation of Thomas's view, which means a morally good action is one consciously chosen as the basis of honest thinking about its suitability to achieve an appropriate end. It does not mean that a good end justifies the use of any means that will work.

Thomas shared Aristotle's view that there is a multitude of substantially different virtues that are interrelated. They agreed that various character virtues make a significant contribution to good actions, and therefore virtues are necessary for living well. Thomas moves the debate from a focus on discrete acts to the character of the moral agent. He sees the natural law and virtues as complementary as he views the virtues as integral to his moral theory. Natural law requires the practice of the virtues to help build our character, and one could say that the practice of the virtues falls under the sphere of the natural law since they are prescribed by reason. However, natural law ethics do not decree precisely how one is to act according to reason. Thomas saw the natural law as a theory of practical rationality, of evaluating actions in terms of intelligibility and reasonableness. Human beings, according to Thomas, have a natural inclination to follow and pursue the good, and his moral theory is teleological in that it identifies basic goods which are grounded in human nature and which provide the reasons for action. The natural law is therefore given by God, and the good is prior to the right. The absolute good is God, and the human good or telos must be a derivative of this absolute: by a 
supernatural gift God's goodness becomes our goodness. From a supernatural point of view, the moral life is about seeing the world through God's eyes. Our common nature determines what is good for us, so right action is action that responds appropriately to the good. Of course, human experience offers countless ways in which the good can be achieved. Thomas claims universal application for his moral theory because we can all know the good and it is universally binding on us all. In sum, natural law entails that all humans share a common nature, basic principles are grounded in this shared nature, these principles are constant and direct humans to their proper ends or goods, and all people can know these basic moral principles. As he says, the natural law is written in our hearts. It follows that natural law and virtue theory enrich Christian ethical discourse.

\section{Every virtue needs a goal}

Virtues for Thomas are the dispositions that give us the capacity to act in a truly human way and to do so consistently and willingly. Virtue enables us to act well and helps us know and desire the good - in other words, what it is to live well. Virtues also help form and shape our attitudes, beliefs and emotions. Virtue is the way in which we attain the good life, the seeds of virtue are part of every human being's nature, and it is up to us to cultivate the virtues so that we may flourish. Thomas thought of virtue as a habit (ST I-II, q. 55, a. 1), and here we will follow Austin (2017) whose Aquinas on Virtue is an excellent clarification of Thomas's understanding of virtue and habit.

Austin employs an interesting methodology that he calls the 'causal approach' in which he follows Thomas, who believed that in searching for a full understanding of anything requires a search for its causes. Austin (2017: xix) states at the outset that the 'first cause of virtue is divine: God is virtue's prime agent, exemplar, and end'. He continues, 'By habit our character is constituted. For Aquinas, the habitual formation of desire toward the good is nothing less than ultimate importance; it is, he says, "necessary for the end of life" (50.5 ad 1)' (2017: 23). Austin clarifies the meaning of habit for the modern reader, since today we think of it as something done unthinkingly and automatically, not consciously and voluntarily. Our modern understanding of habit is seen as a 'mechanistic pattern of response', but Thomas understood that habit must always incorporate practical reasoning about how to act. Austin (2017: 32) explains:

Whereas modern habit is a substitute for conscious agency ... Thomistic moral habits engage rather than bypass the human will. The moral virtues are dispositions to choose to act in certain ways: moral virtue is a habit that chooses, an elective habit (58.1 ad 2). Habits, rather than bypassing human agency, are perfective of it.

Aristotle said something similar, but Austin continues his important clarification on this point: 
Virtuous habits do not diminish but improve our capacity to act from reason and will. A virtue cannot be a modern habit, since the more something is done from modern habit the less it is done from reason and will; it must be a habitus since virtue, as a principle of a human act, is nothing other than a perfection of the rational powers of agency.

Habitus here is what enables a person to act in ways that are excellent; to perform acts effortlessly, immediately and with a sense of joy. Budziszewski (2017: 13) reminds us, 'virtue concerns things we do', providing a useful general definition of Thomist virtue as: 'a good quality of the mind that enables us to live in an upright way and cannot be employed badly'.

Virtues for Thomas are of two kinds: acquired and infused, and the good or flourishing/happiness we seek must correspond to our human nature. Virtues that bring us into conformity with the good of our nature can be acquired through our own efforts and hence are acquired virtues. Throughout the Summa Thomas sees the higher good as supernatural beatitude (eternal happiness) and this good exceeds the capacities of our human nature. Thus, we can only be in conformity with the higher good if God infuses us with grace. This God-given grace, as the root of the infused virtues, provides us with the supernatural capacity to reach eternal happiness. Indeed, the same grace strengthens the acquired virtues. As Thomas writes:

Man is perfected by virtue for those actions whereby he is directed to happiness ... Now man's happiness is twofold. One is proportionate to human nature, a happiness, to wit, which man can obtain by means of his natural principles. The other is a happiness surpassing man's nature, and which man can obtain by the power of God alone .... Hence, it is necessary for man to receive from God some additional principles, whereby he may be directed to supernatural happiness .... Such like principles are called the theological virtues.

(ST I-II, q. 62, a.1)

It therefore follows that a good human life founded on the basis of the acquired virtues does not lead to the fullness of life in communion with God, since that depends on God's grace. The theological virtues are not acquired by human activity but are directly, to use a technical term, 'infused' (poured in) by God. The cardinal virtues, insofar as they aim at achieving natural ends, are acquired. Theological virtues are infused, whereby they are ordered to a supernatural end. However, these theological virtues still require the believer to embrace the practice of these virtues in daily life (Palmer, 2016: 111). As Thomas says (ST I-II, q. 62. a.1):

These additional principles are called theological virtues: first, because they have God as their object, inasmuch as by them we are rightly ordered to God; secondly, because they are infused in us by God alone; and finally, because these virtues are made known to us only by divine revelation in Sacred Scripture. 
They unite us with God.

Budziszewski (2017: 13) says that in Thomas's day readers would have been familiar with this distinction between acquired and infused virtues since they would have been catechised. Today, this is not necessarily the case. This raises the question of how the acquired virtues are related to the infused virtues. Are they distinct in the Christian and somehow coexist, or are all the virtues of the Christian transformed into infused virtues? Thomas appears to answer in the following way. The theological virtues are infused and cannot be acquired naturally. They are supernatural, but they require our participation and need to be practised, and it is these practices that nurture and reinforce the theological virtues. They dispose us to live a supernatural life of communion with God over and above our natural human life. They direct us to the perfection of that communion in the next life. The natural moral virtues are aimed at disposing us to live a natural human life (i. e., in this life) well, in accord with our human nature. We can acquire them in principle by our natural human power, though this has been made difficult for us because sin has damaged our nature. This is why grace does two things. First, it elevates us above our nature, giving us the supernatural theological virtues. Second, it heals our nature, so we are better able to acquire the natural virtues.

Consequently, our natural and supernatural lives are ultimately not separate. The natural is ordered to the supernatural, a life of natural virtue can be lived in service to the love of God. It is important to see that Thomas recognises three kinds of things that can be considered moral dispositions: the Aristotelian or acquired virtues; the infused virtues; and the gifts of the Holy Spirit. There are seven gifts of the Holy Spirit in Catholic tradition: piety, courage, fear of the Lord, wisdom, understanding, counsel and knowledge. The list of the things that are dispositions acquired by practice includes the cardinal virtues. The list of the infused virtues includes some that have the same names as the acquired virtues and some that do not, most notably the theological virtues of faith, hope and love. For Thomas, the infused virtues are the vital virtues and are necessary for the moral life and our ultimate end. However, there are difficulties and problems raised in the literature with how acquired and infused virtues relate to each other, as well as what kind of virtues can be possessed by non-Christians. Whilst Thomas nevertheless commends non-Christian virtue, it seems he believed that non-Christians could only achieve 'imperfect' virtues because they do not always recognise 'God is virtue's prime agent, exemplar, and end' (Austin, 2017: xix).

For Thomas, human beings seek flourishing as the fundamental goal of their moral acts. Since flourishing entails a virtuous life, it cannot be divorced from the community in which we are part. We are not only rational and ethical beings; we are also social and political beings. Solitary or individualistic approaches to ethical thinking lack elements essential to the telos. After all, Thomas says that love (charity) is the virtue that motivates all the other virtues. We only flourish as individuals in relationship, and therefore the telos includes both individual and societal dimensions. The telos is consequently to be found in common projects, shared activities, intimate relationships (Kotva, 1996: 21); from love of parents, to love of children, to love in 
marriage, etc. It includes love of friends, as these relationships have intrinsic worth without denying individuality. The possibility of realising oneself as a person depends on participation in the communal life of the community of which one is a member. Relationships contribute to the common good, and our individual good is dependent on the common good. Thomas also recognises that the consequences of our moral actions are important for self and society. We form character through our actions and choices; through habituation and training; through praise, blame, censure and encouragement. The ideal will never be realised (that is the nature of ideals) so we will never be completely whole. Thomas recognised that only a modest human happiness or flourishing is obtained through our own abilities, and a more perfect end (union with God) is obtained only through God's grace.

\section{Moral formation}

Thomas identifies two main problems in moral formation. These problems concern the intellect and the will, which Thomas believes are interconnected. The first problem is in ensuring that the intellect knows what is right; and the second is in getting the will to perform the action that is the subject of the morally correct choice once it has been identified. For Thomas, the human will, when gifted by God's grace, is (of its nature) inclined to act rightly or to do the true good, but we must be able to perceive and know what the good is in order to be attracted to do the good. The function of our intellect is to develop the capacity to know and evaluate things, while the function of our will is the capacity to choose among alternatives that are understood by the intellect and therefore grasped as good or desirable. This requires an education that is lifelong. Since human nature is not perfect, ignorance can cloud our intellect and distort our will. In summary, character formation for Thomas is helping the intellect to know what is right and getting the will to do it. The virtues guide us on what sort of people we ought to be in order to do the right thing, and the will benefits from the moral virtues which are the virtues of character. McInerny (1997: 122) sums it up:

When we begin to reflect upon action, we are prepared to change our minds. But our ultimate objective is to change our lives. We become the kind of doer we should be by doing as we ought .... In order to change our lives, to become what we ought to be, we must perform repeated acts of the same kind, first against the grain, perhaps, then with less and less resistance, until finally we do joyfully and with pleasure the right thing.

Thomas emphasises again and again that virtuous actions are the product of liberty and deliberation. He taught that every individual possesses the potential to learn, comprehend, analyse and evaluate the world based upon their understanding of reality. Thomas appeared to emphasise individual moral responsibility, to prioritise free will (our ability to control our actions), effectively giving prominence to individual decision-making. However, this does not mean that 
individuals do these things in isolation or within a vacuum, but rather are informed and formed within a tradition and particular Christian teachings and through hearing Scripture. We are moulded within a Christian tradition with its history and culture while simultaneously living in a modern consumer society that deceives us about what we want each time it presents us with superficial choices.

Thomas never restricts himself to a narrow point of view. As Austin (2017: xvii) says, his thought 'is too interrelated to be reduced to a single principle'. Thomas is not a monist or pluralist but a realist who provides objective foundations for moral teaching while allowing for a reasonable pluralism within a constrained diversity. Likewise, Thomas never restricted himself to one framework. Rather, his method sought to understand and answer the multiple objections from numerous sources to his Christian ethics. Thomas's stress on human reasoning therefore cannot be equated with an individualising approach to morality.

All human beings, for Thomas, possess a rational nature with an inclination to live according to reason and thus can know moral truth. If they do the right thing and live virtuously, they will be acting in accordance with their human nature. While we have an innate capacity for virtue, this is not the same as having possession of the virtues. Simply being a Christian therefore does not make you a moral person, nor does not being a Christian make you an immoral person. All of us do things that are right and wrong, regardless of whether we believe in God, and being able to do moral good does not require Christian faith. Those who do not have a religious faith find Thomas's arguments on this reasonable, particularly when there is no direct appeal to Christian revelation or theology. Thomas essentially teaches that, in becoming a virtuous person, we must aim at something, and this must be a moral good. Becoming virtuous is a process, not an event, and involves the mind, the emotions, the body and the community. It involves the whole person, and this focus on the virtues of character can be understood in terms of an evaluation of right and wrong, good and evil. In order to evaluate and respond, we need to experience right and wrong and thereby interpret our experience and act accordingly. We consequently need to be able account for our actions and have some knowledge of the potential results of our actions.

There are two further points that Thomas would have insisted upon here. First, we must be aware, or be able to recognise, that there is a right way or wrong way to act, and second, we need to freely choose our responses. The first point means that we judge what is right by asking: 'Was that good?', 'Was that right?' The second point requires that there be no impediments, such as ignorance, excessive passion, force or fear, that make us less free and less responsible for our actions. Without will and choice, our actions are not voluntary, so Thomas insists upon developing the capacity for free actions - someone who acts voluntarily, consciously and intentionally. In a Christian sense, we must also avoid the dehumanising effects of sin that move us away from the person we could and should be. Because sin is about lying to ourselves and breaking our relationship with God, it has the effect of telling ourselves we are something other than we ought to be. 
Nevertheless, Thomas allows for the possibility that one may faultlessly do something that is objectively bad (see ST I-II, q. 19, a. 5-6) despite his assertion of an objective order of what is good or evil.

Hoffman, Muller and Perkams (2013: 178) expand upon this 'objective order' by detailing Thomas's moral theory in the following terms. First, Thomas is essentially a moral cognitivist, in that his notion of practical truth can be understood and put into practice through prudence. Second, Thomas conceives moral truth as objective and universalist, in that it is valid for all human beings and societies. He believes that normative claims are anchored in a metaphysical order of the whole universe. Third, his moral theory is naturalist, in the sense that it builds on claims concerning the nature of human beings as well as the nature of the universe as created by God. Bauerschmidt (2013: 239) helps us apply this to Thomas's understanding of the virtues:

Moral virtue in particular requires gradual habituation, due to the inherent uncertainty of moral matters, in which determinations of right action involve constantly shifting judgements concerning ends, intentions, circumstances, etc. It is only over time and by consideration of many examples that one can eventually acquire the virtues needed to judge and act correctly. As Thomas puts it it works the way that many raindrops can hollow out a stone.'

In discussing how we acquire the virtues, Thomas describes three stages in the process: discipline, progress and maturity, which Titus (2008: 247-248) explains as follows:

First, growth in virtue involves a disciplined distancing of oneself from what is destructive, empty, or undeveloped. It involves employing law as a sure rule to protect our burgeoning affections and cognitions as well as self-mastery to aid us to resist disordered emotions and to act morally with greater consistency. Second, we advance toward a perfective goal through the habituation (teleological growth) of our malleable capacities. In our quest for goodness, we start to make progress in virtue, encouraged by family, teachers, friends, and the community. We develop patterns of being that are more receptively and actively disposed to goodness and truth, tending toward self-preservation and life in family and in society. Finally, we obtain maturity and rest, as well as joy and spontaneity, in the internal exercise of virtuous ways that express a creative freedom of excellence. Over time, our moral powers can continue to be perfected in the pursuit of personal acts and communal practices that accord with reason, including faith-informed reason.

This model provides both a Thomist philosophy and theology of how to acquire the virtues in a way that transforms the character of a Christian. 


\section{Conscience and freedom}

For Thomas, conscience is being able to both distinguish right and wrong and to make decisions when a person is confronted with difficult moral situations. Conscience is an inner sense, but it cannot be reduced to be being identified with emotion, feelings, opinions or personal preference. It seeks to discover the truth and is a function of the intellect, not simply a voice or feeling inside us. Thomas gives full weight to the role of reason and education in the development of conscience, which develops gradually over time. Therefore, we can say that conscience is a process of reasoning. It has a connection with the virtues and our will, and it can be unreliable since it is not infallible. Conscience must be informed by right reason, and right reason is habituated through the exercise of the virtues. Education therefore must aim at the formation of character and virtue, of reason and conscience. You could say that our conscience needs to be developed, and that it needs to be enlightened by the Church if it is to be authoritative, correct and reliable. The formation of the Christian conscience does not take place in a moral vacuum: it takes place within a living Church, within a tradition. Hence, conscience is a kind of self-knowledge that is at the same time a 'knowing-with' God and the Church. This means that God and the Church are internal to our conscience. Nevertheless, there is a debate, dilemma even, as to whether we should follow our conscience in every situation, since we know that it might lead us to commit unethical actions. While modern theories say it is entirely socially constructed, Thomas believes conscience is given by God.

The Church teaches, along with Thomas, that we should follow our conscience faithfully and that no one should force us to act in a manner contrary to it. However, as Christians we are expected to form and inform our consciences within the Church. Character and its relationship to conscience has not been commonly addressed, but as Gula (1989: 137) says:

We can expect ... that the formation of conscience will involve more than simply answering the practical moral question, 'What ought I to do?' It must also address the prior moral question, 'What sort of person ought I to become?' This means the aim of the formation of conscience is not simply to increase a person's knowledge of facts and values, or skills for resolving a moral dilemma. It must also include the fuller texture of the person's moral character. As long as we can remember that morality is interested in who we are, as well as in what and how we choose, then we will not eliminate character from our consideration of the formation of conscience.

Conscience cannot be considered as a subjective judgement since it is about character-forming choices. For the Catholic, it is about the application of lasting truths to choices about human action. These lasting truths are ultimately derived from moral theology, as Moser and Leers (1990: 10) write: 
So we might say that moral theology is that part of theology which, in the light of revelation and faith lived in the church community, aims to point the way to the full humanization of persons and society, in the footsteps of Jesus Christ and his Kingdom.

In sum, we must strive to believe correctly, and this takes effort on our part to ensure that our conscience is correct.

The relationship between freedom and moral decision-making is vital to understanding the Christian or Thomist notion of freedom. We can begin by explaining what freedom is not within this Christian notion. Age-old questions about freedom and determinism are ongoing and complex (see Campbell, O'Rourke and Shier, 2004), and these debates have given rise to a number of competing theories of determinism that largely reject our moral responsibility and free will. However, the Catholic Church rebuffs a philosophy of determinism that claims people do not have control over, and therefore cannot be held responsible for, their character, thoughts or actions. Our individual freedom is not determined by factors beyond our control, it is not determined by genes and the environment and freedom is not an illusion. Character is not a determinative kind of behaviourism, as Hauerwas (1995: 123) says:

[I]t is possible to understand why character is best understood as a direction or orientation rather than a compelling force. The fact that our character is of a certain kind or denotes a certain kind of orientation does not mean that all we shall do in the future is necessarily programmed into what we are now. Our character gives us direction; but as such it does not have to determine all that we shall be in all that we do .... Character is directing, but it is not compelling in the sense that it represents an external force over which we have no control.

The Church teaches that freedom is a necessary precondition for our being accountable for our actions - we cannot be held morally responsible if we are not free, if our choices and actions are entirely driven by outside authority or force. Freedom cannot be blind obedience to authority, as to be free rules out being told what to do. Character would also be impossible in the absence of freedom, and virtue would not exist because we could not say that what we choose determines who we become. Freedom, also, does not mean that you may do whatever you please, provided you do it freely, as this would simply be pure licence - a kind of freedom for its own sake. Freedom for the Christian is not to be used to satisfy our appetites and desires or to be used as an end in itself.

Owen Flanagan (1991) argues that any attempt to present a single anthropological portrait normative for moral conduct is futile, because such a normative portrait would be a fiction. A realistic psychology, he says, teaches that the possibilities for moral excellence are as unlimited as the individual is complex. It is worth noting here Kohlberg's moral reasoning model in which he explains that a child, in order to become a morally mature person, must pass through predictable 
sequential stages of moral reasoning to the point that they make free moral decisions based on a personally constructed moral code. The thinker at this final stage is Kohlberg's idea of the morally excellent person. Flanagan insists that individuals can only become morally excellent persons by being themselves and that we ought not to preconceive a definitively excellent person. He argues that we need simply to identify the minimal conditions that must be met to call any person virtuous. The difficulty for the Christian view here is that Kohlberg (1981) describes the development of moral reasoning without specifying any moral content. This is why Kohlberg had little room for virtues and character. He misunderstood Aristotle by assuming that Aristotle separated the moral from the intellectual and that virtue is simply gained by practising virtue without the engagement of reasoning. However, Aristotle insisted that reasoning and deliberation are integral to virtue. Therefore, while Peters (1981) calls the tension between the inculcation of virtues and the development of autonomous reasoning the 'paradox of moral education', the Christian response is that the moral content of freedom is love and service, not autonomous choice and self-determination. Freedom and our ability to reason are essentially expressed and motivated through love for God and service to our neighbour, which require us to be rational. This Christian emphasis on love that is recognised throughout this text and cannot be underplayed. We have seen how Aristotle linked virtue to reason, but Thomas links it more to love as he says: 'Love is the form of all virtues'. Indeed, we need the virtues to express love, and we are only virtuous when we are able to love. Love is the central and fundamental principle for living as a Christian believer.

The Christian definition of freedom is much broader in scope, for it is not about how many choices you have, but rather, it appears, it is about whether or not you can choose the good. However, it isn't clear that it makes much sense for Thomas to suppose that I can choose to be bad. According to Thomas, we are by nature oriented to good, although we can have inordinate or disordered attachments to some genuine goods. Thomas is clear that human acts are deliberate voluntary acts we are responsible for our actions, and these actions are undertaken for a particular purpose or end. In turn, this means that reason and will are important since acts that carry responsibility are fully voluntary. Choices are simply the act of our will in which the will moves towards one thing in preference to another. Choice is informed by reason, and deliberation is the means to the choice which form dispositions to act. The process of self-direction established by our intellect and will ends in a choice. In essence, there can be no morality without personal freedom. However, we are only truly free if we choose to act in a way that is good. If we do not, then we effectively lack freedom in the Christian sense. This is why Veritatis Splendor (Pope John Paul II, 1993: n34) teaches that: 'It is only in freedom that man can turn to what is good'. The Catechism of the Catholic Church (para 1733) also stipulates that there is no true freedom except in the service of what is good and just, and that the more one does what is good, the freer one becomes. In the end, to do evil is an abuse of freedom. Ultimately, we are responsible for our moral choices to God, individually, in relationship to others and, socially, as members of the Church. 
Pinckaers (1998), who has a concern for the educational implications of the Church's teaching on freedom, illustrates the meaning of Thomas's teaching by providing two concepts of freedom, each with its own theory of morality. The first concept sees freedom as the capacity to say 'yes' or 'no' based on our inclinations and in the absence of any rules or regulations to consider - simply our own will. In this definition of freedom, there are no restrictions on our choices, and whatever we choose is right for us. Pinckaers believes this is the modern view of freedom; the radical ability to do good or evil indifferently by having the power to choose between good and evil. This he sees as a matter of self-assertion and of power only. He believes that in seeing free will thus as a choice between contraries, free will is essentially indifferent to goodness. Free will is thereby reduced to power - an ability to decide between options, which has no particular concern for the good or happiness as the goals of human life. He calls this the 'freedom of indifference'; a freedom characterised as self-centred as it is indifferent to the morality of the actions in question.

In contrast, Pinckaers, drawing on Thomas, believes that we have a natural desire for the good, which brings happiness. Therefore, freedom can alternatively be conceived as the capacity to engage in excellent acts of virtue. This second conception he calls 'freedom for excellence', which is our power to be the best human being we can or, one could say, our capacity to help shape the best character we can become. Pinckaers says this must be done over time and through education. This morality of happiness and virtue is a response to the ultimate end of human action, which for the Christian is the beatitude, composed of a participation in the eternity of God and the life to come. Freedom for excellence is our goal as Christians, and as Christians we make a major commitment to follow Christ within his Church, meaning our moral decisions need to be informed by our faith. We need to begin this process through education, by encouraging a desire in students to seek excellence and to take personal ownership of their actions in order that they pursue the good that brings personal fulfilment or flourishing. This concept of freedom is not a law of restrictions or obligations because the student needs to constantly ask: 'What do I want to be free to do?' Freedom here is freedom for something, not simply freedom from something. According to Pinckaers, this freedom helps us grow and achieve excellence in virtue, even though Catholic anthropology sees us all as works in progress. Through a disciplined and dedicated Christian life, we live out the major commitments we have made as Christians. Students in school are constantly encouraged by teachers to do the right thing, and the right thing is often obvious, even if the student does the opposite. Teachers teach students to rule out immoral choices and even to avoid a kind of radical individualism that is unconnected with the community of the school or unmotivated by the school community's considerations. The good character the school promotes is rational and sociable, with appropriate choices and actions.

Pinckaers (1995: 355-356) explains freedom for excellence by using the example of a student learning a foreign language. The student must learn the grammar of the language, the rules and conventions of the language, and work tirelessly to speak the 
language fluently. This process is both difficult and tedious, requiring time and the full commitment of the student until they can speak the language without conscious effort, at which point they possess freedom for excellence in the language. In the same way, the Christian learns to understand and practise the virtues as well as listen authentically to what the Church teaches, even if at times it is tedious and difficult. Consequently, just as the proficient language learner does not consciously have to work to avoid errors in speaking or understanding the language, so too the truly free individual does not consciously have to work to avoid sin. God's grace, as the healing of sin, is necessary here, as Farley (1995: 162) observes:

Without God's grace, without God's forgiveness of pride and loss of selfwholeness, acts of freedom and accountability would remain bound by a darkness of the self - a darkness whose levels of even goodness would be overshadowed by the constant presence of inauthenticity.

Pinckaers's (1995: 377-378) general reassessment of the role of human freedom is in accordance with Aristotle and other ancient philosophers, as well as with scripture, the early Church Fathers and Thomas. As Christians, we need to have a reasonable certitude that what we choose and what we do is right and good. Freedom for us therefore entails a moral responsibility to choose the good. You could say that the Church presents us with what we think makes for the happiness we seek by providing the virtues that make for this happiness and inviting us to reflect. We know that the virtues provide a kind of internal guide that make choosing the good easier over time, while external support is provided by the Church's moral teachings. We could say that we must use our freedom to consider Scripture and what the Church teaches, seek advice from members of the Christian community, and ask whether our choices negatively impact on our relationships with God and our neighbour, and do all of this in a spirit of prayer. Only then must we decide and act. From this perspective, we cannot make choices in isolation from the authoritative role of the Christian community. We cannot make decisions as Christians in ignorance of what the Church teaches, particularly in a world full of counterfeit versions of happiness. In the end, obeying rules imposed on us from outside or going with our feelings and emotions are two false choices. The Church expects us to think before we follow its precepts.

Thomas believed that human society is the flowering of human nature because by our nature we ought to be friends to one another. Human society is made up of a hierarchy of human communities, starting with the family, which forms villages and towns that grow into cities and nations. Nations form governments that issue laws, and these laws, according to Thomas, have a moral pedagogy. He saw human nature as continuous with the order of the natural world. Thomas outlines four elements in his definition of law: it must be a rule or norm grounded in reason, intended to foster the common good, made by legitimate authority and duly promulgated (ST I-II, q. 90, a. 1-4). Every government encourages or discourages certain human actions and therefore has a role in shaping moral character. 
Jones (2015: 607) argues that laws have the capacity to order a people to virtue, in the sense that legal frameworks help cultivate their moral flourishing - law is designed to make the citizen good. Since human beings are social animals and naturally form communities, they require the help of others to achieve a virtuous life. Laws therefore have a formative impact on citizens by reforming the bad person and assisting the good person to acquire the virtues he or she wishes to possess. The law, for Thomas, entails a positive pedagogy that seeks to nurture citizens' moral virtues. Thomas addresses the virtues before he discusses the law, making clear that the law must be understood and supported by his treatise on virtue.

McInerny (1997: 95-96) provides us with a precise summary of Thomas's philosophy or functioning of character when he notes:

Since human actions by definition proceed from reason and will and are either good or bad, in order to be good they must proceed from correct reason and from a will that is orientated to the good. The habits that guarantee correct knowledge of the good and steady appetitive orientation to it are virtues. There are, then, generally speaking, two seats or loci of virtue - reason and appetite. In short, there are intellectual virtues and there are moral virtues.

Pinckaers (1995: 399) adds to this by describing the principal characteristics underlying the moral teaching of Thomas thus:

His is a theory based on the ultimate end of man ... His focus is happiness rather than obligation; the virtues, which develop our natural inclinations to goodness and truth ... His theory is based on wisdom, fostering the intimate collaboration of intellect and will, rather than on voluntary obedience.

We could give a brief summary of the main elements of Thomas's theory of education, beginning with his belief that we are free rational beings that makes possible our rational choice. Thomas emphasised that we are created by God in His image and likeness and that our final end is to be with Him in eternal happiness. Thomas directs our attention to this final end and reminds us that the practice of the virtues is the road to this end. For Thomas, human nature is created by God to pursue the highest good, and the good is what everyone wants. God does not simply exist, He is knowable. As human beings we are finite and therefore limited in our ability to assess what good actions are as well as in the strength of our will to actually do them. We therefore need to be habituated to do what is virtuous in order to acquire a good character, because virtues allow the will to be drawn to the good, which requires gradual habituation. Being virtuous and good character are the first steps to the acquisition of wisdom. There must be an emphasis on moral training and habituation in acquiring the capacity for practical wisdom and education prepares us for learning through the acquisition of the intellectual virtues (ST. I-II, q. 57, a. 1) while simultaneously preparing us for living through the moral virtues. The 
virtues give coherence to our actions, and, although Thomas explicitly refers to the education of children (ST. I-II, q. 95, a. 1 and ST. II-II, q. 10, a. 12), children become virtuous prior to the full development of rational understanding. Thomas believed that children gradually and incrementally become more reflective and discerning. Ultimately, virtuous living is the practice of good judgement and intelligent action. Parents are the first educators of their children; other agents and institutions share this duty in a secondary sense. Individuals comprise and constitute the state, but the basis of society is the family (ST. II-II, q. 154, a. 2). Thomas indicates two purposes for marriage: procreation and education of children. Parents, therefore, have obligations to care for and form their children in virtue. Nevertheless, the state, without minimising the rights of parents, also has certain rights in education, particularly when parents cannot discharge their duties. In pursuit of the common good, the state must see that people have a good living and this includes providing appropriate districts for building houses that are built a suitable distance apart with streets that are constructed in order to make the homes more beautiful. Education is also concerned with this common good, and learning takes place when one person teaches another so that they come to know what they previously had the capacity to know before. However, education is also the search for truth and wisdom, which we find ultimately in God. An education that does not have God in mind is no education and will not lead to personal fulfilment.

\section{Thomism in education - a historical survey}

Thomism is the philosophical school that arose as a legacy of the work and thought of Thomas Aquinas. Thomism is not monolithic since it contains various Thomism's and covers a multitude of competing interpretations (see Shanley, 2002; McCool, 1996: 154; and Kerr, 2002) with many claiming to represent the true and accurate interpretation of Thomas. It should also be noted that while Thomas did not write directly on philosophy of education and seldom used the word educatio, a Christian philosophy of education can be derived from his writings on human nature, his idea of knowledge acquisition, and from his thoughts on human potential in life (Rose, 2015). It is possible to work with a Thomist way of understanding education that is faithful to the Christian tradition and simultaneously committed to renewal - a Thomist approach that is intellectually expansive and at the same time practically relevant to education. In short, as Slavin (1942: 314) observed: 'Thomas Aquinas wrote no ex-professo on the philosophy of education but in another sense it may be said that he wrote nothing but a philosophy of education' because he 'understood the nature of the educable'. A series of Dominican scholars have addressed the question of Thomas's philosophy of education (Slavin, 1942; Donlon, 1952; Conway, 1960; and Ashley, 1995, 1996 and 2006).

One further comment needs to be made, and that is that few agree on how to read the works of Thomas. There is a disconcerting diversity of claims in the literature about what notion is key or fundamental to understanding Thomas's 
ethics. Consequently, who counts as an authentic Thomist thinker is continually disputed. We are presented with numerous authors presenting multiple (and yet often minuscule) themes that attempt to interpret Thomas by using inaccessible language that can only lead to misunderstanding (see Keenan, 2009). Austin (2017: xvii) identifies the problem when he says: 'Aquinas is a holistic thinker' and there 'is a nexus of interrelated ideas'.

Apart from continuity within the Dominican Order, Thomism's influence has varied over time and place (see Cessario, 2005). In the mid-nineteenth century, a revival of Thomism in the Church, particularly in Italy and France, known as Neo-Thomism, was given sanction in the encyclical Aeterni Patris (On the Restoration of Philosophy) of Pope Leo XIII in 1879. Pope Leo explained: 'We exhort you strenuously for the protection and adornment of the Catholic faith ... that you restore the golden wisdom of Thomas, and spread it as widely as possible' (1879: para 114). His plea was the importance of establishing an interface between faith and reason and establishing a stronger relationship between philosophy and faith. This became a movement that was used to justify a Catholic philosophy of education best outlined in Pope Pius XI's encyclical Divini Illius Magistri (On the Christian Education of Youth) of 1929 which featured prominently in Catholic teacher training (see Berner, 2008: 274-276). This encyclical (1929: 36) understood Christian character in the following terms:

Hence, the true Christian, product of a Christian education, is the supernatural man who thinks, and acts constantly and consistently in accordance with right reason illumined by the supernatural light of the example and teaching of Christ; in other words, to use the current term, the true and finished man of character.

Numerous scholars, including theologians and educationalists, worked together to produce detailed syllabuses for schools and universities that were influenced by a number of Neo-Thomist theological approaches. Educational philosophers were also attracted by and engaged with Thomism, even though some did not work within a Catholic tradition. Mainstream philosophers like Maritain (1943) and others such as Dufault (1946) became interested in the theory of Christian education as inspired by Thomas and continued to write about it and advocate that it was the only serious basis for a well-rounded education. However, they debated its meaning and methods abstractly and disputes arose. By the 1950s there was still a general consensus that Catholic education should be based on a theory inspired by Thomism, but there were already signs of discontent, particularly with the practice of the theory. As Donlon (1952) noted of religious education courses in Catholic institutions at all levels: 'there is considerable dissatisfaction with courses presently available in the colleges and that there is a great desire to do something constructive to improve them'. Donlon, as a Dominican, wrote his Theology and Education as a justification for a Thomist education, but even he was prepared to see that something was not right in the practices adopted at the educational level. 
Being a Thomist in education had come to mean, for some, adhering to an official Church-approved orthodoxy that was enforced to prevent innovation and which became associated with a fortress Catholicism.

Thomism had to show that it could be relevant and could contribute to the concrete concerns of teaching and learning. Even before the calling of the Second Vatican Council in 1962, fewer academics were publishing Thomist-inspired critiques of education (see Goodrich, 1958), albeit on the eve of the Council the bishops continued to hold firm in lectures, such as the 'Aims of Education: NeoThomism', given by Bishop Beck at Manchester University in 1961 (see Beck, 1964). After the Council, we see the almost complete eclipse of a distinctive Catholic philosophy of education, which made Elias (1999) ask in his article title: 'Whatever happened to a Catholic Philosophy of Education?' No philosophy or, more importantly, theology, that challenged the dominant educational principles of the new entirely secular educational theories was forthcoming from the Catholic Church, far less one based on Thomism (see Dearden, 1982). Traditionally, an education based on Catholic theological doctrine was the unifying principle of the teaching offered in Catholic institutions. By the 1960s, education had come to embody certain values from the social sciences, in particular psychology, without any relationship to theology, which, in any case, many considered an illegitimate way of approaching education. Hence, a distinctive Catholic theology declined and was replaced with an accommodation with or, some would argue, a warm approval of secular modernity. Important here was that Catholic language and practices about moral virtues in ordinary Catholic life were located and expressed in the world of devotions. In the 1960s Catholics were still learning from their teachers that the saints had particular virtues, and these were understood and used practically in their common day-to-day lives. In contrast, O'Meara (1997: 281) now noted that the virtues had become too abstract, mechanistic and even philosophical to be understood and applied easily in ordinary Catholic daily life. Indeed, many who described themselves as Thomists became narrowly focused on technical disagreements.

O’Meara (1997: 255) reminds us that any claim to a restoration of virtue ethics overlooks the many presentations of virtues in Catholic moral theology from 1860-1960 in numerous journals and books. The early part of the twenty-first century has seen a number of small conferences and some books and articles linking Thomist ideas to education, but these are simply the publications of academics that do not come to a conclusion or consensus nor have influence on mainstream Catholic educational institutions. At the opening of the twenty-first century, Shanley (2002: 20) observed:

What emerges from ... twentieth-century Thomism is that the tradition has always been marked by the tension between conservation and innovation, between doctrinal fidelity and dialogue. This has been true throughout the entire history of Thomism, and it will continue to be true in the new century. How could it be otherwise? A Thomism that stayed in a defensive intellectual 
ghetto would cease to be a living tradition, while a Thomism that accommodated itself to every philosophical movement would cease to be Thomism. Each age demands both a genuine fidelity to the original and a genuine willingness to dialogue with what is new in philosophy.

Nevertheless, there has been a small resurgence of interest in the works and thought of Thomas for education and learning.

In the United States and Canada, a series of Catholic higher education institutions were able to engage and develop Thomist ideas while in Britain this was limited to seminaries and teacher training colleges. The seminaries used Latin manuals, mostly imported from Europe, that introduced a supposedly Thomist approach to theology and philosophy by repudiating, according to Daly (1980: 19), any 'experiential, affective or intuitive mode of thought' while truth was revealed as "eternal, immutable - untouched by the "flux of history". Interpretation was left to the Church hierarchy. In the UK's teacher training colleges, papal encyclicals and other Church teachings on education played the dominant role until the 1960s. The colleges had resisted naturalistic psychology in the earlier part of the century, but by the 1950s there was a gradual shift that privileged a psychological framework of education, replacing the vague form of Papal Thomism that had previously been current. This process of secularisation of the college curriculum accelerated in the 1960s and 1970s to such an extent that the educational courses in Catholic colleges were indistinguishable from non-Catholic institutions, and, as Berner (2008: 295) observed: 'education became severed from divinity'.

Nevertheless, a volume on Papal Teachings: Education (1960) was published in the eve of many of these changes in education, which confidently proclaimed that the Church teachings showed 'how clear and secure in her [The Church] position and how unchanging and sure her directives as she leads mankind on the way to salvation .... There is no shadow of doubt, no shortcomings, no lacuna in this teaching'. This collection of encyclicals and papal teachings on education covered the period 1820 to 1960 and could be found in many Catholic schools at the time. While the volume focused on the rights of the Church and governance in education, it also gave emphasis to formation in virtue and character throughout the teachings, but, surprisingly, with only a few references to Thomas.

The English and Scottish Catholic Churches were much centralised and clericalised under ultramontane influence. Norman (1985: 107) writes of the English Catholic Church in the first half of the twentieth century: 'The leadership at the centre in these years was characterised by administrative skill and the encouragement of devotional practice rather than by the sort of scholarly enterprise to which many of the nineteenth-century bishops had been given.' Catholic learning had, he claims, 'passed into something of a quiescent phase'. Nevertheless, Britain contributed to the Neo-Thomist revival in a number of significant ways. The English Province of the Dominicans produced the first complete and reliable translation into English of Thomas's Summa Theologiae, begun in 1911 and published by Burns and Oates of London in 22 volumes. There was also the popular 
and much praised work St. Thomas Aquinas by G. K. Chesterton, written in 1933, and between 1946 and 1975 the nine-volume History of Philosophy written from the Thomist point of view by Frederick Copleston S. J. was published, not forgetting his Aquinas, which was published in 1955.

It is interesting that T. S. Eliot was able to say in 1926 that the influence of neo-Thomism has reached many persons who have probably never read a word of St. Thomas' (cited in Wilson, 2014: 100). Eliot's own literary journal, The Criterion, was accused of being 'an organ for a "Frenchified" doctrine called neo-Thomism' (cited in Wilson, 2014: 100; see also Bredin, 1972). Even in British universities, there was awareness of Thomism and sometimes even advocacy of it. The Professor of Moral Philosophy at the University of St. Andrews in 1920, and subsequently at the University of Edinburgh, A. E. Taylor (1920: 25ff), wrote:

In short, if we mean to be philosophical, our main concern will be that our beliefs should be true; we shall care very little whether they happen to be popular or unpopular with the intellectual 'proletarians' of the moment, and if we can get at a truth, we shall not mind having to go back a long way ...

... on the Continent splendid work has been done in the requickening of genuine philosophical thought by an influence which has, so far, not made itself widely felt among ourselves. I mean the revival of Thomism ... I am convinced, if its representatives will only maintain it at the high level characteristic, for example, of the Italian Revista Neo-Scholastica, has a very great contribution to make to the Philosophy of the future, and is much more deserving of the serious attention of students in our own country than the much-advertised 'impressionism' of Pragmatists and Bergsonians.

However, in education, there was no serious intellectual contribution in Britain to a Thomist approach. The main question faced by those who embraced Thomism is summarised by Erb (2004: 466): 'In what way, and to what extent, ought their philosophy to be authentically Thomist while simultaneously engaging mainstream contemporary philosophies by contributing in some meaningful way to concrete particular concerns of the present age.'

\section{Thomism and education in the twentieth century}

It is generally accepted that Neo-Thomism provided the theological framework for Catholic education between 1900 and the 1960s, essentially providing a unifying philosophy. In the first half of the twentieth century, Neo-Thomism in education was used for four clear purposes in Anglo-Saxon countries: (1) to defend Catholicism's right to establish and maintain schools within a Protestant culture that was anti-Catholic; (2) to provide a coherent philosophy of Catholic education; (3) to guide religious education in schools; and (4) to provide the basis for compulsory courses for undergraduates in theology and philosophy in Catholic Universities. More specifically, Catholicism in America was thought to be 
characterised by three other impulses in this period: 'to promote the intellectual standing of American Catholicism, to defend the Catholic faith and its adherents from distractors, and to redeem what was seen as a drifting and fragmented secular culture' (Sparr, 1990: xi-xii). The societal context for this was one of cultural and religious alienation for Catholics in a country that was officially mission territory until 1908.

Pope Leo XIII wrote to the American bishops in April 1887 to advise on the establishment of the Catholic University of America by directing that the philosophy taught in the University should 'clearly follow the method of the Angelic Doctor' (Quod in novissimo, 10 April 1887). As Bizley (2007: 701) observes: 'In short, Thomism served as a Catholic "philosophy of life" and sustained a comprehensive "world view" with which to engage an American nation ever more uprooted from its Christian foundations'. However, many Catholics claimed allegiance to Thomism without having read any of the writings of Thomas or even commentaries on them. Thomism was thought to imbed changeless Catholic principles. In addition, Thomism was increasingly seen as being aligned or indistinguishable from the increased centralisation of ecclesiastical authority and doctrinal orthodoxy, Rober (2015: 264) noting: "Neo-Thomism" thus has functioned as a stand in for a kind of manualist or system theology, closely aligned with the hierarchical structure of the church, that fostered a narrow interpretation of the work of Thomas Aquinas'.

The opportunity, in these circumstances, for an authentic Thomism to emerge and be understood, was limited. What therefore arose was often a distorted version of Thomism half-understood and seemingly used to justify an often closed and controlled system of thinking about education. Guzie (1960a and 1960b) compiled a list of Thomist educational literature, but it is a list noted for its paucity and lack of significant works. However, there were exceptional individuals who worked at the pastoral and practical levels to promote a more authentic Thomism (see Conway, 1960).

In the United States, a series of Catholic priests trained in Thomist theology became leading professors of education. Four in particular are worthy of mention: Edward Pace, Thomas Shield, George Johnson and Gerard Sloyan. All taught at the Catholic University of America between 1900 and 1960, and all saw character formation as an integral part of Catholic education. All four were educational reformers who sought to assist the Church by finding alternative ways to students simply memorising doctrinal formulas found in the catechism. They sought to foster critical thinking and self-activity in education and encouraged the practice of students questioning what they were taught. They defended the Church's official philosophy of education while arguing for the deployment of more progressive teaching methods in Catholic schools (see Elias and Nolan, 2009). They recognised early on that some teaching strategies, particularly in teaching religion, were outdated and often defeatist in approach. Despite this, Catholic publishers printed millions of popular Bibles, prayer books, spiritual readings, devotional guides, catechisms, liturgical texts as well as histories, biographies of saints, poetry and fiction for use in parochial schools. 
Between 1870 and 1920, religious textbooks in Catholic schools in the United States were generally imported and translated, particularly French apologetic works influenced by the 'Leuven Neo-Thomist School'. These texts used Thomas's argumentation and vocabulary (Van Wiele, 2007: 788). Van Wiele (2007: 786) noted that these textbooks were used as a systematic defence of the Catholic faith and were aimed at the more advanced students who had a better intellectual grasp of the Catholic faith, and he notes: 'heated polemics dominated Catholic apologetic textbooks, which emphasised the points on which Catholic teaching differed from nonCatholic and non-Christian convictions'. For many clerics, it was also the case that strict adherence to what was being taught signified orthodoxy. However, Leuven, as a Centre for Thomist studies, dissociated itself from extreme partisans of tradition and attempted to steer a path between traditionalist and progressive ideas (see Heynickx and Symons, 2018). Pace, who became the first head of the psychology department at the Catholic University of America, and who had studied Thomism in Louvain under Desire Mercier, also became the first professor of education at Catholic University and was America's first practitioner of the new Thomist tradition (Misiak and Staudt, 1954: 34, 68-72). Mercier was a Catholic pioneer of scientific psychology and, along with Pace, sought to incorporate Thomist principles into modern scientific findings. Both agreed that the Church accepts inference based on controlled observation as a valid guide to truth.

Education departments in universities, teachers of religious education in schools, and the National Catholic Educational Association (NCEA) were dominated by priests and religious orders in the first half of the twentieth century. There were, however, significant lay people who promoted a Thomist approach to education. Charles Lischka (1926: 22-23), a layman, became a professor of education at Georgetown University in 1931, but had in 1926 addressed the NCEA, identifying two groups within Catholic education: one conservative and the other progressive. He noted that: 'Their differences concern not essentials, but accidentals, not principles, but practice, not truth, but opinion.' He stressed that both groups were loyal to the authentic principles of a Catholic education and believed that while social context may change, human nature did not. A good illustration of this is Edward Fitzpatrick, who was born in New York in 1884 of Catholic parents, but did not attend Catholic parochial or High School. He was educated in the public school system and attended Columbia University where he completed his Bachelor's and Master's degrees in English literature and subsequently a doctorate in education. At no point did he study philosophy or theology, but he was influenced by Pope Leo XIII's encyclical Aeterni Patris (On the Restoration of Philosophy), becoming a life-long advocate of a Thomist philosophy of education. He first became an administrator and held the position of Secretary to Wisconsin's State Board of Education before joining Marquette University's Graduate School as Dean in 1924. He was never a professor of education and yet saw his purpose as articulating a Catholic understanding of education from a Thomist perspective and became influential in that role, receiving four honorary doctorates for his writing on education. 
He founded the Marquette University Institute for Catechetical Instruction in 1924 and became editor of the Catholic School Journal; a position he held until his death in 1960. In 1929 he was also appointed President of Mount Mary College in Wisconsin. Ronald Rutkowski's (1990: 25ff) doctorate on Fitzpatrick provides an illuminating insight into what Fitzpatrick saw as his Thomist philosophy of education, and Fitzpatrick's (1953) Thomist philosophy of education is worth summarising:

First, Fitzpatrick began with a definition of a human being: a human being is rational and has free will, is capable of thought and has the power of selfactivity or self-determination. In this definition there was a spiritual dimension: a human is in the image of God, the spiritual element in human existence. The spiritual element mandated education's responsibility for spiritual formation.

Second, Fitzpatrick rejected the idea that Catholic education sacrificed the student's self-activity for authority and for tradition. Self-activity was the cornerstone for teaching all disciplines. Emphasis on the child required properly trained teachers and an appreciation for methodology. According to Thomas, human beings were rational, and learning is a natural tendency. Human beings have the potential to learn, and, through understanding, the student derived meaning from things. Understanding was a natural function of the student's mind, and understanding marked the mind's activity in the process of learning. What is learned should therefore never be passively or mechanically received. It must rather be actively transformed by understanding into the very life of the mind. Learning perfected reason, and learning extended throughout one's life. Selfactivity was primary. Textbooks and other aids to learning were secondary. The textbook is a subordinate instrument in the educative process, only a tool of the teacher and an aid to the student. Education is futile if only memory is trained, and students regurgitate to their teachers the platitudes and the inert truths of instruction. It is why improved textbooks for religious education classes ranked first on Fitzpatrick's agenda.

Third, education had the serious task of moulding an individual: it is an integration of personality - a character guided by the ultimate ends of life. The purpose of education is to give an individual full possession of his or her powers to see, to dream or imagine, to conceive, to judge, to reason, to feel, to create. Imagination enlivened knowledge. Imagination, will and play contributed to the formation of character. Imagination enabled the student to see relationships, to ask questions and to be creative. Thomas rejected what would later be called behaviourism because it denied such free will. Whilst habits were necessary for the will to achieve the good, habits required direction and that direction was conscious recognition of the good for human beings. Character is not merely habits, instincts, sentiments, impulses, urges, drives, feelings and emotions, or even will. Character is all of these organised into an orderly life.

Fourth, materialist philosophies permeated arguments from supporters of tests and measurements. For Catholic education, the world is destined for a 
supernatural end. The vision of the supernatural made one's understanding of the world radically different from secular views.

In all this, Fitzpatrick saw five wrongs in the Catholic education of his day:

First, Catholics often equated quality with the number of Catholic schools built and with the number of students enrolled in Catholic schools. Second, there was a pervasive attitude that Catholic schools were immune from internal criticism. Parents were reluctant to criticize Catholic education. Third, Catholic students neither appreciated nor responded to the ideal presented to them. Fourth, Catholic schools either neglected to or refused to clearly formulate their contribution to society. Fifth, the objectives of Catholic education were often confused.

(Rutkowski, 1990: 85)

Fitzpatrick wrote his Thomist ideas up in Philosophy of Education (1953) that built upon A Catholic Philosophy of Education (1942) by John Redden and Francis Ryan, another two lay professors of education at Fordham University. Fitzpatrick clearly did not view Thomism as preconceived answers that he merely fell into line with nor as a monolithic philosophical system. Brown (1940), comparing 'the Catholic view' with other educational perspectives, offered a summary of the working Thomist principles which constitute the foundations for Catholic educational theory and practice:

1 A classical understanding of the universal, absolute, and unchanging character of truth and the objectivity of right and wrong.

2 Faith in the power of human reason, aided by divine revelation to attain true and certain knowledge of reality.

3 A vision of human nature composed of a spiritual soul and a material body, originally possessed of integrity lost through original sin, but ultimately recoverable through the power of grace which elevates human nature to participation in the divine life. The source of this educational unity was a common philosophical framework within which Catholics developed their understanding of the relationship between religion and education and the nature, purposes, scope, and methods of Christian education.

These Thomist principles offered a sense of unity for the Catholic school curriculum and provided an integrated view of human life. Character formation was understood as part of the catechetical process. The encyclical of Pope Pius XII in 1950, Humani Generis, endorsed the use of these principles in education. There was also an earlier debate about education in public schools and in universities that was influenced by some of these Thomist principles by leading non-Catholic thinkers such as Mark Van Doren and Mortimer Adler (see Van Doren, 1943; Garstin, 1949; and Lacy, 2014). Van Doren (1943) spoke in Thomist terms about 'the 
powers of the person are what education wishes to perfect' and 'liberal education is nothing less than the complete education of men as men' (cited in Garstin, 1949: 359). Adler read the Summa Theologiae in English in the1920s, which influenced his subsequent writings (see Lacy, 2014) with him declaring that: 'A synthesis of faith, reason, religion and philosophy, supernatural and natural knowledge is necessary for a unified culture' (cited in Rugg, 1947: 8). Robert Hutchins, Scott Buchanan, John Erskine, Stringfellow Barr, Clarence Faust, Alexander Meikejohn, Joseph Schwab, Richard McKeon and many other intellectuals associated with the Great Books tradition were referred to as Adler's 'confreres in the pseudo-Thomist counter revolution' by the progressive educationalist and disciple of Dewey, Harold Rugg (see Lacy, 2013: 50, and Rugg, 1947: 37). None of these philosophers were initially Catholic, and few would have accepted the attribution of being 'Thomist' even if there plans to reform the University curriculum drew on both Aristotle and Thomas. By the 1940s, Northrop (1952) believed that Thomism, as a worldview, was important and growing outside of Catholic circles in the belief that Thomist principles could be adapted to nonreligious educational institutions. Even Rugg (1947: 614) believed that the attention given to Thomist ideas in the 1930s was 'one of the sensational fortuitous circumstances of modern educational history', although he thought it a retrograde step.

Non-Catholic perceptions of Thomism were not entirely negative, but there was a general distrust of it as is seen in John Zybura's (1927) collected responses from a questionnaire survey of prominent international intellectuals, mainly philosophers, about their attitudes towards Thomism. Some thought that Thomism 'worked wholly by authority - that the thinker is committed beforehand to certain conclusions' (Zybura, 1927: 12), but most were not as negative or unfriendly. John Dewey, who responded, gave a number of interesting psychological and pedagogical reasons behind the lack of interest among modern philosophers in Thomism. His comments were intended to encourage a general dialogue with Thomism (Zybura, 1927: 29-31). First, he believed that non-scholastic thinkers had been brought up in Protestant traditions and associate Thomism with theological dogma which they do not accept. Second, that there had been a decline in belief and in the content of Christian revelation. Third, that Thomism was too rationalistic and not sufficiently empirical. Fourth, that there was a clash between modern science and Thomism, and finally, that Thomism did not help with resolving social and political problems despite the fact that Thomism had given rise to Catholic social teaching. Others felt that Thomism was inaccessible to students because of the terminology used. Nevertheless, these perceptions did not prevent 18 American universities awarding the famous Belgium Thomist, Mercier, an honorary doctorate, including Harvard in 1919 (Misiak and Staudt, 1954: 38).

Jacques Maritain is considered a key figure in how Thomist approaches to education took root in America, more so than in Europe, between the 1930s and 1950s. A French philosopher and convert to Catholicism, Maritain visited America to lecture at the University of Chicago and New York University in the late 1930s, and in the academic year 1942-43 he delivered the Terry lectures on 
Education at the Crossroads at Yale University. Maritain also gave lectures at Notre Dame University and the Catholic University of America, but his main focus and activities were in non-Catholic universities. In 1948 he became Professor of Philosophy at Princeton University, indicating the importance attached to the kind of Thomist philosophy he advocated: an 'open Thomism' that would be conservative and yet progressive (see Boland, 2010). In 1955, the Yearbook of the National Society for the Study of Education invited him to contribute a substantial essay on the Thomist philosophy of education, which again demonstrated that Thomism was being treated as a philosophy of education that ranked with other modern philosophies. He was making Thomist philosophy of education a valid option, and he outlined a Neo-Thomist integral realism for education in Education at the Crossroads (Maritain, 1943), Man and the State (Maritain, 1951), On the Use of Philosophy (Maritain, 1961), and Integral Humanism (Maritain, 1968).

Some of those Thomist principles are well summarised by Gutek (1997: 290) as: (a) permanence - the emphasis on a reality that is permanent rather than changeable; (b) teleology - a universe that is ordered and has a plan towards ends or purposes; (c) constancy of human nature - human beings have traits that are unchanging through the generations; (d) essential universality of human nature human beings are fundamentally the same, everywhere; (e) fundamental aims of education were universal and timeless - since human nature is constant and universal so are education's purposes; ( $f$ ) rationality as the defining characteristic of human beings - the function of education is the cultivation of human reason; and (g) the study of humankind's intellectual patrimony - 'the funded wisdom of the human race [is] recorded in certain classic works' (Gutek, 1997: 290). This integral realism focuses on valuing the human person and was also theological in orientation. It was these Thomist principles of integral realism that influenced intellectuals outside the Catholic Church. Maritain (1943: 3), like Thomas, defended classical education and argued that we must not neglect the broader purpose of education, which is to lead students to fulfilment in life. He believed that wisdom was the true goal of education, but that schooling did not make the student wise, it simply prepared them to advance towards wisdom in adulthood. While Maritain was critical of progressive education as a philosophy, he agreed with many of the progressive teaching practices and methods, so long as they did not lead to a secular ideology (Maritain, 1962: 44). In the end though, Maritain believed that character could only be cultivated by both reason and religious faith.

On the question of teaching methods, Fitzpatrick, Redden, Ryan, and Lischka shared with Pace, Shields, Johnson, and Sloyan their opposition to memorisation as the sole teaching method in catechesis. They all believed that conventional methods of teaching religion and training for character must be frankly faced and constructively criticised. Fitzpatrick knew that the mere fact that the child has memorised parts of the catechism is no guarantee that the child can see the significance of the explanation that comes to his or her mind. All of them would have agreed that you can never make the Christian by merely learning the words of catechisms nor repeating theological formulas. Elias and Nolan (2009) refer to 
the first four as progressives, but all of them were really progressive traditionalists, which was a compromise between traditionalists who did not want to change the question-and-answer methodology and radicals who sought to abandon the catechism in favour of a methodology emphasising child psychology. Progressive traditionalism retained the catechism as the basis of religious instruction with a continued insistence on some memorisation, but was progressive insofar as it stressed greater explanation of the text and its enrichment by narrative, pictures, hymns, poems, etc. (Rutkowski, 1990: 119). These educationalists were not dissenters, but used the knowledge from the growing field of developmental psychology to improve the presentation of the Catholic faith.

Another example of progressive traditionalism is the work of Bernard Louis, a Christian Brother, who wrote the Catechist's Manual in 1907. In this manual it is advised that religious educators should start from the experience of the child and should take account of child psychology. It emphasises that catechesis should be taught progressively, depending on age and maturity of the student. Questioning is also highlighted as an essential tool in teaching (Capelle, 2012: 74). The only female writer on Thomism in education in the early twentieth century was Mary Helen Mayer (1929). She not only wrote an excellent and widely read text on Thomist teaching principles that highlighted the role of teachers in character formation, but also produced the first English translation of Thomas's De Magistro, a translation only recently updated by Mooney and Nowacki (2011). Fitzpatrick knew her as a doctoral student at Marquette and he helped arrange for her doctorate to be published by the Bruce Publishing Company of Milwaukee, America's largest Catholic publisher at that time, as part of a series of monographs on education that promoted Thomist ideas. He provided the Foreword to her book The Philosophy of Teaching of St. Thomas Aquinas. Indeed, many of the thoughts and practices of these progressive traditionalists echoed the changes that took place after the Second World War in religious education teaching. Veverka (1993: 530), however, notes that

Because of their understanding of religion as a broad cultural reality, Catholic educators tended to be more concerned with paideia than pedagogy, with ultimate ends rather than technical means, with the formation of character, attitude and ideals rather than the transmission of knowledge or the development of specific skills for their own sake.

She tends to classify most of these educationalists not as progressives, but as conservatives. The progressives, she claims, felt that the Catholic synthesis was broad enough to incorporate many of the insights and practices from secular education. They would have agreed with the Catholic Bishop Brady (1928: 545) that the Church seeks to turn out people 'of character, whose first endeavour is personal sanctification and salvation, who will be good neighbours, good citizens, worthy members of the Kingdom of God'.

In 1935, the Sacred Congregation of the Council (now the Congregation for the Clergy) instructed diocesan bishops to establish Diocesan Catechetical Offices 
to oversee the provision of catechesis in schools. It was the case that some religious education textbooks in Catholic schools adopted a question-and-answer format similar to the catechism and provided the answers which were expected to be accepted without question. However, to claim that these are examples of 'strict Thomism', as Stafford (2019a: 165) does, is absurd. Stafford, like many other educationalists who are unaware of the historical record, make strong and unsubstantiated assertions about the perceived malevolent influence of Thomism on education prior to the 1960s. Thomism, for them, takes on a form that goes beyond being a philosophy and is understood as some kind of oppressive ideological system. Critics often retrospectively construct a concept of Thomist education that never actually existed. A variant of Thomas's thinking on education certainly became overly associated with a rigid Catholicism in the twentieth century. In a sense, it is largely true that Thomism became or was deployed as a philosophical and popular ideology imposed from the top within a closed system of thought with which to counter modernism, Marxism, or idealism. In the guise of educational philosophy, it gradually became viewed as intolerant and static, reduced largely to expressing the correct formula and seen as opposed to educational innovation despite the work of the progressive traditionalists. McInerny (1969) called it 'rigid, catechetical Thomism' which resulted in Catholic religious education textbooks being taught by rote memorisation and barely half-understood. This variant did not penetrate the religious or even educational depths of Thomas's original writings, but instead was used in an authoritarian way, enforcing conformity and commanding obedience in shaping the thoughts, beliefs and actions of students and teachers alike, particularly in parochial schools. This distorted Thomism was increasingly conflated with the Church's institutional structures and reactionary rubrics and could be both authoritarian and defensive, features that were alien to authentic Thomism.

The Church's powerful use of this constructed single monolithic philosophical system to enforce compliance in teaching and learning caused a general antipathy towards Thomism, and by the time of the Second Vatican Council it was seen as passé, obsolete and out of tune with modern educational thought. There was a growing desire for renewal and change in the Church. The societal context for this reaction can be seen in the immediate decades after the Second World War, in which the Church continued to experience the shock of totalitarianism, communism, atheism and materialism. Profound and rapid changes occurred, and it was also a period of prosperity in Western societies that had become more pluralist and diverse. There was an increasing focus on human rights, social justice and a growth in secularism, and by the 1960s schools were introducing new teaching methods that conditioned young people to question authority. There was also a proliferation of protest movements and demands for change - even for its own sake. The Church realised that philosophy, which was a mode of thought controlled by reason and not by authority, could not be imposed by decree. In consequence, John Paul II, in his 1993 encyclical Veritatis Splendour, seemed to abrogate his predecessors' imposition of Thomism on the Church in the following 
words: 'Certainly the Church's Magisterium does not intend to impose upon the faithful any particular theological system, still less a philosophical one' (see Pereira, 2002: 177-178). Yet in his 1998 encyclical Fides et Ratio (On the Relationship Between Faith and Reason), he calls for a return to the philosophy of Thomas.

Nevertheless, modern critics like Stafford (2019a, 2019b) simply make the mistake of confusing authentic Thomism with the legalistic version that appeared to predominate in the Church before the 1960s. As Ashley (1995: 76) notes:

Whereas the moral theology of Thomas Aquinas is teleological, treating the morality of human acts in relation to the ultimate end of the human person, the theology of the pre-conciliar manuals was deontological and legalistic .... Whereas Thomistic moral theology emphasises the development of character (virtue) through good action, the moral theology of the manuals reduced virtue to obedience to law, and emphasised casuistry.

The period prior to the Second Vatican Council contained many Catholic academics who regularly questioned teaching methods in Catholic schools, particularly in regard to catechesis. These academics, religious and lay, were characterised by their unity and consistency on a Thomist philosophy, but there were great differences in how these principles were to be translated into educational policies and practices in schools. Indeed, it must be recognised that rote learning and poor teaching were also common in schools run by the state, which is why John Dewey and many others promoted experiential and discovery learning. Fitzpatrick liked to point out, however, that it was Thomas Aquinas who advocated these 'new' educational learning approaches almost 700 years prior to Dewey. Fitzpatrick, like other Catholic educators of the period, rejected Dewey's philosophy of pragmatism and his instrumentalism, but accepted many of his approaches to teaching and learning. Dewey was a fierce critic of the state school system of his time, accusing it of authoritarianism, stunting the growth of students, discouraging students from engaging in meaningful activity or participating in the classroom, and administering harsh punishments. He rejected Thomism in education since he thought it purely speculative and empirically unverifiable (see Gutek, 2005: 247). He also eschewed metaphysics and the idea that truth might be constant and universal. He therefore had little time for either Aristotle or Thomas and, like other progressives of the period, 'argued that ethics had to do with values rather than facts and that truths about values were not derivable from true descriptions of how human beings happened to be or behave' (Miller, 2012: 281).

It is worth distinguishing between values and virtues here because of the confusions that are generated in school mission statements. It is often the case that virtues and values are treated as if they have the same meaning. The two are similar, but distinct. Values tend to be goals which are largely aspirational; they represent intentions, something to work towards, but they can be very abstract, subjective and vague. Values can be collective beliefs or individual convictions. Not all values are appropriate and they can lack real identifiable meaning as well as 
being held only temporally since they are often changeable. The language of values can have a descriptive quality, focusing on not what good 'ought' to be chosen, but rather the good that a person or group prefers. Any values that are proposed to give direction to life are generally viewed as fluid and consequently result in an absence of the criteria for what values are good and what values are bad. In the end, there is a tendency not to make any judgement of the truth of the values held reducing even normative value judgements to statements of preference or feeling. In contrast, virtues are more permanent qualities that are considered morally good and desirable. Virtues are realised intentions that result in lived right conduct; they are more objective, and therefore they can be observed in our character. Virtues are the foundation of good character and are ordinarily used normatively. To talk about Gospel values, which are not first defined as virtues to be realised within a faith to be lived, can easily be reduced to confused and ambiguous values talk. The values of the Gospel require also that the teaching of the Church be at the heart of the integral formation of Christian character. The Catechism of the Catholic Church speaks in the language of virtues, not values. Indeed, Christ did not talk in the language of values and neither did the Gospel. It is important to begin by detailing which values found in the Gospels inform and reflect the religious identity and practice of a Catholic school. Today, schools, even some religious schools, avoid the use of the word virtue because they believe it too associated or linked with religion and therefore prefer the more relativistic use of values which they think is more neutral. This relativism, that assumes Gospel values (peace, love, forgiveness, solidarity, justice, equality etc.), can potentially forget Christ, wanting the message but not the messenger.

Modern criticisms of the teaching methods in Catholic education in the first half of the twentieth century blame 'Thomism'. However, if you compare the school practice of teaching of history with that of religious education in the first half of the twentieth century, there are surprising similarities. First, both subjects emphasised memorisation of facts - long lists of dates and names in the case of history. This was achieved through repetition. Second, students were passive rather than active in the classroom, with little questioning allowed. Third, history was used as a political tool to instil patriotism, which was accompanied by both poor teaching strategies and dubious historical content in lessons (see Cannadine, Keating and Sheldon, 2011). As in religious education, it was only in the 1960s that significant changes occurred with a more progressive and child-centred approach. However, there were significant moves in the 1920s and 1930s to revise the content and methods in Catholic religious education textbooks (see Gleason, 1937), and there was already a move to 'child-orientated methods' and 'learning by doing' in religious education in Catholic schools (Baumert, 2013: 6 and 7). Christian character formation was consistently emphasised in the period, and a religious education text called My Character Book provided worksheets that emphasised the natural virtues (see Campion and Horan, 1930). Baumert (2013) charts the many significant changes in the approach to teaching religious education in the period up to the 1960s. Doyle (2007: 343) sums it up thus: 
The 1960s also brought on, however, a widespread confusion concerning how religious teaching and secular knowledge fit together. On an existential level, no matter what teachers were trying to tell them, students had to make a choice between the Baltimore Catechism on the one hand and the modern world on the other. The magnetism of sex, drugs, and rock 'n roll exerted a strong attraction to youth in those days to which Catholics were not immune. For many, being an intellectual and being a Catholic no longer seemed to fit together.

Despite the partial demise of Thomism as the official philosophy of education in Catholic schools up until the early 1960s, it was not replaced with any other distinctly Catholic philosophy. Instead, Catholic education largely embraced idealist and subjectivist philosophies or ways of understanding and practising education. No attempt was made to construct a new Catholic synthesis in education, but rather ideas were borrowed from here and there with little concern of whether they were compatible with Catholic teaching. The emphasis was now on individual freedom and conscience. This lack of a theology or philosophy of Catholic education has led to widespread confusion and to serious ongoing questioning of Catholic identity in all educational institutions run by the Church. While today there is a general resurgence of Thomas's account of the virtues (see Inglis, 2002), there is in comparison only a very modest revival of Thomism in educational thought (see Boland, 2007). It is a modest revival whose methodology and modes of inquiry need to be determined within philosophy itself and not by authorities external to the discipline. In other words, we should not allow Thomist educational philosophy to repeat the mistakes of the twentieth century, but rather it must be applied, offering relevance and purpose in educational thinking and practice. Above all, it must respect individual freedom and reasonableness along the lines that Brand Blanshard (1973: 130) wrote in The Uses of a Liberal Education:

What do we mean when we call a man reasonable? We mean at least this, that in his thinking and acting he shows objectivity of mind. And what is this? It means being realistic, impartial, just, seeing things as they are rather than as fear or desire or prejudice would tempt one to see them. The reasonable person will suit what he thinks and claims to the facts. He will be ready to give up an opinion if the facts are against it, and adhere to the opinion in the face of inner and outer pressure if the facts require it. His claims against others and their claims against him he will view impersonally and with detachment; he will not ask more for himself than is just merely because he is he; nor will he allow himself to be put upon for the like reason; he bases his self-respect upon respect for the sort of justice that is itself no respecter of persons.

Thomas, I have no doubt, would have agreed. Those looking for something more solid on which to build and form character will find that Thomism provides such a foundation by being optimistic about the possibilities of human 
intelligence. It provides a synthesis of learning from experience and learning from faith - a fusion of faith and reason, religion and culture. As Elias and Nolan (2009: 6) note about Thomas:

What is prominent in his thought is a great respect for natural knowledge alongside revelation, an appreciation for the natural conditions of human life, a healthy belief that all truths that humans can arrive at are God's truths, and finally a conviction that all truths are capable of being reconciled with one another.

There are of course prominent educationalists who reject any link between education and theology. Hirst (1976: 155), an educational atheist, believed that 'any attempt to justify educational principles by an appeal to religious claims is invalid'. However, one of the most prominent critics was a Catholic professor of education who led the Department of Education at Notre Dame University until its closure in the 1970s. James Michael Lee claimed he was a Thomist, but, as America's most prolific religious educator of his time, he strongly argued that education has nothing to do with theology (see Newell, 2006). Lee admired the view of Thomas as the rebel and innovator, the theologian who ran counter to the prevailing theological and ecclesiastical establishment, but it is difficult to see how Lee could describe himself as a Thomist. He argued that theology has no normative function in education, and that faith is merely an abstract construct seen in a cluster of characteristic behaviours. He believed that education must be founded exclusively on empirical data, and he identified the social sciences as almost entirely with God's immanent working in the world. He appeared to be uncritical of the social sciences, suggesting they were value free and that education itself was no different from other types of learning derived from the social sciences. His many critics in the academy as well as within the Church counter argued that Christian education always arises from philosophical and theological assumptions within a cultural or historical setting.

Lee's successor as the most influential Catholic religious educationalist in the United States was Thomas Groome. Like Lee, Groome trained for the priesthood but, unlike Lee, was ordained and subsequently left. Groome (2018: 149) received a seminary education in Ireland that was based on the teachings of Thomas and claims that this influence of Thomism has remained with him throughout his life, particularly the idea that there are great universal truths that are always and everywhere true. However, Groome has never described himself as a Thomist and also viewed education as largely political. In a public lecture I gave at Boston College on 14 November 2019 on 'Formation in an Age of Uncertainty', Groome delivered the official response to the talk with generosity and even appeared to endorse the Aristotelian notion of formation in the virtues.

\section{A changing Thomism for education}

As we have seen, by the 1950 s it was becoming clear that there was a growing taste for eschewing any 'meta-narrative' as a Catholic philosophy of education. Students 
in Catholic schools were no longer viewed as living in a unified world of Christian culture, and the idea of 'change' in education became the prevalent slogan. Normative classical Western culture was no longer intelligible to many educators, who were increasingly led by the educational issues of the day often decided by others. Thomism in education was inevitably challenged and seen by some as a static theory indifferent to varied cultural and historical contexts. Thomism, traditionally understood as a philosophy based on permanent principles, applicable for any age and place, began to be viewed by some as simply first principles in a static, unchanging world. In contrast, contemporary education was understood as preparing students for a changing world. Bernard Lonergan, a Jesuit and serious intellectual heavily immersed in Thomist philosophy and theology (but not uncritical of it), published 'The Transition from a Classicist-World-View to Historical Mindedness', which appeared to reflect some of these concerns (Lonergan, [1974] 1996). He had earlier led a two-week summer institute in 1959 at Xavier University, Cincinnati, on the philosophy of education for 55 Catholic educators, mostly religious (Lonergan, 1988). He delivered 20 lectures and announced at the outset:

I am not a specialist in education, but I have suffered under educators for very many years, and I have been teaching for an equally long time .... You can listen to me as I speak about philosophy and its relation to theology and to concrete living. But most of the concrete applications, the ironing out of the things, will have to be done by you who are in the fields of education and philosophy of education

(Lonergan, 1988: 24)

Lonergan sought to reflect on Catholic education, principally on higher education, saying little about elementary and secondary education. His lectures were complex, drawing, as they did, on his unique theology and transcendental method, but they are essentially concerned with an existentialist quest for personal meaning in life. For Lonergan, the purpose of education is self-transcendence, that is, to seek knowledge and the desire for 'finality' of human experience. This purpose entailed striving towards a 'higher viewpoint', to gradually come to know a deeper reality that would lead to an 'ultimate'. In developing his educational theory, Lonergan does not ignore Thomas, but his relationship to Thomas becomes complex, which raises the question of what kind of Thomist Lonergan is. He is certainly not a classic Thomist.

Lonergan's vision of education promotes what he called 'cosmopolis' that embraces the particularity of one's cultural and religious traditions (see Gunn, 2018). It emphasises dialogue with others and mutual understanding, mutual respect and mutual interdependence in a globalised world. For Lonergan, education is concerned with discovering oneself, and he linked this to ultimately being oneself. Education is defined as the continuous revitalisation of learning about life, and so education is what one does for oneself. It is about constructing one's own world through expanding one's horizons. The teacher nurtures the desire of the student to know by evoking questions and encouraging curiosity, but it depends on the willingness of the 
student to make the effort. He argued that human consciousness consisted of experiencing, understanding, judging (or discerning) and deciding. Consciousness here is divided into distinct types of psychological operations that effectively unfold human character sequentially. The experience element concerned sensations, images and perceptions as a way of being aware of reality; understanding concerned questioning and insights that helped understand experience; discerning concerned reflection and asking and assessing whether our understanding is correct; and, finally, deciding concerned evaluating what is worth acting upon from what we know and so understanding that our decisions change us and make us who we are meant to be. Each of these stages of development has a distinct way of structuring reality and forms a hierarchy with the later stages dependent on going through the earlier stages. The whole process focuses on questioning and discovery and anyone who has experienced the Spiritual Exercises of St. Ignatius would see clear similarities in this approach, particularly in the quest to reach a decision. Lonergan is interested in how things work - how human beings come to know something - and he therefore adopts an empirical approach. Thomas did not look at the operation of knowing nor conduct an empirically based account of what goes on in the human consciousness. Lonergan believed he was expanding on Thomas's thought by asking the question 'What are we doing when we are knowing?' by looking into how human beings get to truth. His General Empirical Method was the result. It was general because it applied to every human being regardless of culture or ethnicity and empirical because it sought patterns in how our intelligence or reasoning functioned. However, it seems strange that Lonergan sought to empirically ground ethics without conducting any empirical studies.

Lonergan's educational approach is extremely demanding of any student or teacher, because he claimed that his philosophy of education fosters in human beings the will to be attentive, intelligent, reasonable, responsible and to care and love more. He also saw wisdom as something we move towards by striving to know. In regard to school education, Crysdale (2002: 568) explains that Lonergan was concerned with a conception of human development which moved from moral virtues that children accepted by socialisation into a culture to learning the tools of discovery in order to discover truth and virtues for themselves. Lonergan appears to omit a consideration of virtue from his rather ambiguous approach to education and rarely, if ever, does he refer directly to human character. There is also little engagement with the infused virtues and the implications they have for education. Despite having completed a doctorate on Thomas and grace, it is surprising that few references are made to the Holy Spirit's actions in the educational process. He also says practically nothing about education in schools. Nevertheless, in outlining how we change ourselves by re-creating ourselves Lonergan is indicating that we are freely choosing character development. His idea of moral agency requires both moral and religious conversion and therefore requires free and intentional participation in moral character development. To be morally converted allows human goodness to flourish in individuals and community, as evidenced in good acts. Moral growth, for Lonergan (1972: 40), takes place within our social and historical 
context, and we direct our choices towards the truly good by finding consistency between knowing and doing. Lonergan is aware that within the Christian context it is necessary to accept and receive the gift of grace through the Holy Spirit. As he said (1972: 241), it is the 'complete transformation of the whole of one's living and feeling, one's thoughts, words, deeds and omissions'. Elements of classical Thomism remain in Lonergan's explanations, and he still argued occasionally, like a classical Thomist, that Catholic theology and philosophy ought to inform the education experienced in a Catholic University:

To put it more concretely, we go to great expense to have Catholic universities; yet, our professors cannot be anything more than specialists in physics, specialists in chemistry, specialists in biology, specialists in history. If they can search and search for philosophic and theological aids to give them the orientation that would be specifically Catholic in their fields and still not find them, because neither philosophy nor theology are doing their job of integrating, then we have a problem.

(Lonergan, 1990: 119)

However, Lonergan's approach to education could indicate the birth of a new Thomism and simultaneously a departure from classic Thomism. Lonergan ([1974] 1996), in a lecture in 1968, expressed his personal conviction that 'a mature Catholic theology of the twentieth century will not ignore [Aquinas]; it will learn very, very much from him; and it will be aware of its debt to him'.

Aristotle's Ethics and Thomas's Summa Theologiae seek to define and describe the limits that nature places upon human beings. They each seek to educate humanity on how best to live within the limits of nature, through the practice of the virtues, in order to achieve human flourishing. It is an education in what it means to be human and liberates us not only from external restraints, but from our internal appetites and desires. Therefore, freedom is not something we are born with, but is achieved in a long process of learning. It is a learned capacity to govern oneself using our natural reason and is achieved through habituation in the virtues. Thomas saw life not simply as a life of flourishing rationally, but ultimately as an intimate union with God. As Young, McCluskey and Van Dyke (2009: 6) write: 'we are teleological beings, created by God with a particular function and for a particular purpose'. The deeper purpose of character formation is therefore preparing us for union with God.

\section{Suggested reading}

Austin, N. (2020) Aquinas on Virtue, Washington DC: Georgetown University Press.

Excellent introductory chapter.

Cessario, R. (2001) Introduction to Moral Theology, Washington DC: Catholic University of America.

This text is widely read and used, and chapter 3 focuses on human freedom, conscience, choice and the virtue of prudence. 
Jensen, S. J. (2013) Living the Good Life: Beginners Thomistic Ethics, Washington DC: Catholic University of America Press.

An easy introduction to Thomism.

McInerny, R. (1997) Ethica Thomistica: The Moral Philosophy of Thomas Aquinas, Washington DC: Catholic University of America.

Good introduction to Thomism.

Pinckaers, S. (2001) Morality: The Catholic View, South Bend, IN: St. Augustine's Press.

Excellent and accessible short introduction to Catholic moral teaching.

Pinckaers, S. (1995) The Sources of Christian Ethics, London: Continuum.

Detailed academic introduction to moral theology.

Maritain, J. (1943) Education ant the Crossroads, New Haven, CT: Yale University Press.

Maritain's most quoted book on Thomism and education.

\section{Questions}

Do we have the right to make moral judgements?

Are sins of thought less significant than those of deeds?

What is the difference between divine law and natural law?

How does sin affect our ability to live virtuously under natural law?

Why are the cardinal virtues important?

What are the theological virtues, and how do we define them?

How is the cultivation of virtues presented in the Bible?

Is religion rational?

Is teaching students right from wrong an appropriate educational goal?

What is your vision of the good person and the good life that education seeks to promote?

What are the differences in the ways in which Christians perceive moral character and formation over and against the ways in which psychologists and philosophers do?

Which philosophy today would you choose as the most suitable basis for character and virtue education?

In what ways are character and virtue education an expression of the mission of Christianity?

If parents are the first educators, what is the role of teachers in moral education?

What does it mean for the virtues to be 'infused' by God?

What is the role of grace in Christian virtue development?

What are the strengths and limitations to a monist and pluralist approach to moral decisions? Which position do you lean towards?

What is conscience from a Thomist perspective?

What is the relationship between freedom and moral decision-making? 
How do the theological virtues of 'faith, hope and love' contribute another dimension in forming character?

What practical ways might someone participate with God in cultivating the 'infused virtues' of faith, hope and love?

What does it mean to develop character in a community? 


\section{Chapter 4}

\section{Christian character and pedagogical virtue education}

There is no commonly accepted list of virtues in modern society, and yet historically groupings of virtues that are similar, but distinct, have emerged in diverse cultures and religions. Every culture has its list of virtues, and religions universally encourage its adherents to cultivate particular virtues. In the Republic, Plato first listed the 'cardinal' virtues, while Aristotle, in his Ethics, lists 18 virtues for human flourishing. Aristotle distinguishes between political, social, intellectual and moral virtues, but provides no hierarchy of virtues, simply stating that they are all interconnected. The Old Testament tends to list vices, but Jewish writers also had their list of virtues, and the New Testament has lists of both virtues and vices. List of virtues can be located in Corinthians 6: 6-8; Galatians 5: 22-23; Ephesians 4: 32; Philippians 4: 8; Colossians 3: 12; 1 Timothy 4: 12, 6: 11; Timothy 2:22, 3: 10; James 3: 17; 1 Peter 3: 8; and 2 Peter 1: 5-7. The most important Christian list of virtues is contained in the Beatitudes in Matthew 5 and were included in the Catechism of the Catholic Church. The Romans had many of their own virtues as befitted their culture and incorporated: industria (hard work); honestas (respectability); salubritas (wholesomeness); firmitas (tenacity); and constantia (perseverance). By the eighth century, there arose chivalric virtues inspired by Christian virtues which, among others, commanded knights to defend the cause of the widow and orphan, shun excess in eating and drinking, and cautioned them that envy, hatred and violence separate men from the Kingdom of God. We have seen already how Thomas mentions over 50 virtues, but emphasises the theological virtues of faith, hope and love, followed by the cardinal virtues. The Renaissance stimulated greater interest in the classical virtues of Greece, while after the Reformation and Enlightenment, we see a rise of utilitarianism and Kantianism which forced these lists of classical virtues to take a back seat. In recent years, there has been the popularising of Bennett's (1997) list of virtues and Peterson and Seligman's (2004) 24 virtues for developing character strengths. The Virtues Project, an international programme for the promotion of kindness, justice and integrity (founded in 1991) lists no fewer than 52 virtues. Indeed, many authors today identify more than a hundred virtues that are expressed in similar but often distinct ways and which take into account gender, racial, ethnic, environmental and animal-rights sensitivities. This huge expansion of virtues may even include 'virtue signalling', which is simply stating your hatred of something and believing this makes you more virtuous than those who actually 
practise virtues, such as those who visit the sick, give money to charity or are kind to a stranger. Virtue was once seen as an inner ethical quality concerned with reforming oneself to make one better, but today it can simply mean wishing to reform society without involving any personal transformation.

It is interesting that within a short period of 12 months between 1992 and 1993, three important books were published in the United States that addressed the case for character and virtues in education. All three rejected values clarification methods together with the notion that students entirely constructed their own moral worldview or improved their moral reasoning skills through discussion of moral dilemmas. They all agreed that the primary mission of education is to initiate students into the moral heritage of society and develop habits of virtuous actions as a way to build character. The first, which was practical in scope, was by Thomas Lickona (1992) and explicitly sought to cultivate virtues in schools, which he described as good human qualities that are good for the individual's character and for society. The second, by William Kilpatrick (1993), spoke of the 'attractiveness of goodness', and he favoured the teaching of stories over open-ended moral dilemmas which simply emphasised autonomous decision-making. The third, by Wynne and Ryan (1993), argued that moral decision-making is not made in a void. They all echoed Hauerwas, who had earlier argued that moral decisions are always made in the context of one's own narrative. While all of these authors were Christians, they wrote with a largely secular audience in mind and represented an important and influential first wave of pedagogical writings in the field upon which others could build. Many educationalists have followed by constructing largely secular curriculums and educational rationales for teaching and learning character virtues (see Arthur, 2003: 113-143). Lickona, Schaps, and Lewis (2007) constructed Eleven Principles of Effective Character Education as the essential elements of character education. These principles serve as criteria that schools and groups can use to plan character education and to evaluate the character education programmes, books, and curriculum resources available. All of these developments served as the background to a major initiative in the UK in 2012.

\section{A character education framework}

The Jubilee Centre for Character and Virtues was established in 2012 against a backdrop of ongoing ethical scandals in banking, medicine, law, education, sport and the arts. The Centre specifically saw schooling and the training of professionals as a moral endeavour, not a technical enterprise. The aim was to explore, through research, how one could teach and train for virtues, character and wisdom in order to avoid ethical blindness in students and those training for the professions. It appeared to the Centre that many students and professionals acted unethically because they were unable to transfer ethical principles they had been taught into practice. Indeed, while many people claimed that they were morally committed to ethical behaviour, they nevertheless engaged in behaviours that contradicted these standards. At the same time, it was noted that these people continued to profess these standards while avoiding feelings of remorse, guilt, shame, distress or conflict. 
They effectively lost themselves by making too many compromises which bent the rules and led to whatever was expedient. Sternberg (2002) had earlier recognised that intelligent people and those with expertise in the public domain can act foolishly and described how they are susceptible to one or more of six fallacies of thinking: (a) unrealistic optimism - they believe what they do will always work out fine, regardless of whether it makes sense, (b) egocentrism - they view decisions only in terms of how it benefits them, (c) omniscience - they think they are all knowing and lose sight of the limitations of their knowledge, (d) invulnerability - they think they can do whatever they want and are too clever to be caught (and even if they are caught, they figure out they will get away with it), (e) omnipotence - they think they are all powerful and can do whatever they want, and (f) ethical disengagement they ignore the ethical dimensions of the problems they face because they are above such matters and ethics is for others. Sternberg believes that wisdom is more important than knowledge or intelligence and that we can teach for wisdom. The Centre agreed with the analysis that teaching to enhance abilities, expertise and achievements is not sufficient for a satisfying life. It also noticed that this ethical deficit was being felt and generated a demand from schools and professional organisations to get involved in the education of character.

The Centre emphasised that schooling is not primarily about transmitting knowledge but rather about the search for meaning and moral purpose in life. Education is always concerned with character, and in Arthur (2020: 10-11) I provide a descriptive list of what character means:

First, character involves change over time - it is not fixed, static or set, but is malleable and continuous .... Character is also visible in our conduct. Second, character is shaped within and by cultural and civic context and therefore is a social, not entirely individual process .... Third, it involves choice and autonomy .... Fourth, it involves a life dominated by principles and convictions, the ability to discover or define one's life mission without blind conformity to the convictions and actions of others .... Fifth, it involves observable actions according to these principles, convictions, rules and life mission .... Sixth, it involves regularity of expression - which requires a certain stability in moral attitudes and a persistence of effort .... Seventh, it requires will power and motivation as well as the ability to act on appropriate judgements.

Undoubtedly, character formation entails intentional instilling of certain motivational elements in the student.

In terms of implementing this vision for character, the Jubilee Centre developed A Framework for Character Education in Schools (2017, first published in 2013), which states particular aspects of and goals for character formation:

1 Character is fundamental: it is the basis for human and societal flourishing.

2 Character is largely caught through role-modelling and emotional contagion: school culture and ethos are therefore central. 
3 Character should also be taught: direct teaching of character provides the rationale, language and tools to use in developing character elsewhere in and out of school.

4 Character is sought freely to pursue a better life.

5 Character is educable: it is not fixed and the virtues can be developed. Its progress can be measured holistically, not only through self-reports but also more objective research methods.

6 Character depends on building Virtue literacy.

7 Good character is the foundation for improved attainment, better behaviour and increased employability, but, most importantly, flourishing societies.

8 Character should be developed in partnership with parents, employers and other community organisations.

9 Each child has a right to character education.

10 The development of character empowers students and is liberating.

The Centre claims, based on its extensive research, that character can be taught, caught and sought. Taught is understood broadly as providing educational experiences in and out of school that equip students with the language, knowledge, understanding and skills that enable character formation. Caught is when the school community provides the example, culture and inspirational influence in a positive ethos that motivates and promotes character formation. Sought is when the student over time makes certain commitments and desires freely to pursue their own character formation. The Centre claims that these virtues can be categorised into four types: intellectual, moral, civic and performance. These four categories are seen as interdependent, and because each one needs the other, they need to be integrated in practice.

These virtues are defined as follows:

Intellectual virtues: Those virtues that are rational prerequisites for right action and correct thinking - for example autonomy, reasoning and perseverance. The intention is that students will think and react in the right way so that they do the right thing, and in so doing promote human flourishing for all. These intellectual virtues are required for the pursuit of knowledge, truth and understanding and include how to interpret, analyse, evaluate, compare and judge - all essential to a well-formed mind that can reason well.

Moral virtues: Those virtues that enable us to respond in ethically sound ways to situations in any area of experience. These are the virtues of courage, self-discipline, compassion, gratitude, justice, humility and honesty, which every child should learn.

Civic virtues: Those virtues necessary for engaged and responsible citizenship. They include service, citizenship and volunteering. These civic virtues assist the flourishing of each person and promote the common good of society. Civic virtues are essentially a specific subset of the moral virtues. 
Performance virtues: Those virtues that can be used for both good and bad ends the qualities that enable us to manage our lives effectively. The virtue most commonly mentioned in this category is resilience - the ability to bounce back from negative experiences. Others include determination, confidence and teamwork. These virtues, which are really skills, should derive their ultimate value in being enablers and vehicles of the moral, civic and intellectual virtues.

\section{The framework of virtues}

The virtues listed in each of the four categories are not entirely random or arbitrary (Table 4.1). The first six to seven virtues listed in each category arose from their frequency as found in the Centre's research with tens of thousands of students, reported in the Centre's publications. Despite this, they are not listed with any priority or hierarchy.

All these virtues or groupings of virtue are interconnected and certainly do not exist in silos. Together they aim to develop practical wisdom, which enables us to perceive, know, desire and act with good sense so as to flourish as individuals within a flourishing society. The overall aim of education in this framework is to form

Table 4.I Framework of virtues

\begin{tabular}{llll}
\hline Intellectual virtues & Moral virtues & Civic virtues & Performance virtues \\
\hline Autonomy & Compassion & Citizenship & Confidence \\
Critical thinking & Courage & Civility & Determination \\
Curiosity & Gratitude & $\begin{array}{l}\text { Community } \\
\text { engagement }\end{array}$ & Motivation \\
Judgement & Honesty & Neighbourliness & Perseverance \\
Reasoning & Humility & Service & Resilience \\
Reflection & Integrity & Volunteering & Teamwork \\
Resourcefulness & Justice & Friendliness & Grit \\
Vision & Respect & Charitableness & Bounce-back-ability \\
Foresight & Care & Co-operation & Industriousness \\
Openness & Kindness & Courtesy & Dedication \\
Optimism & Generosity & Tolerance & Ambition \\
Pride & Fairness & Trust & Leadership \\
Forbearance & Selflessness & Helpfulness & Communicativeness \\
Imagination & Loyalty & Patriotism & Enthusiasm \\
Awareness & Forgiveness & Affability & Diligence \\
Creativity & Honour & Dependability & Productiveness \\
Wonder & & & Persistence \\
\hline
\end{tabular}


people so that they can live well in a world worth living in. A good life includes all the things that make life worth living: family, friends, health, pleasure and so on. The framework, with its list of virtues in each category, is intended to give a sense of direction to educational efforts in teaching the virtues as well as give some sense of priority in what is important. It aims to develop the virtue literacy of students.

The framework does not refer to spiritual virtues, even though English education policy since the Education Reform Act of 1988 requires that schools promote the spiritual development of each student in school. This raises the question of whether there are virtues that merit consideration as spiritual qualities linked to character. By way of background, it has been noted already that attending to the spiritual dimension raises issues of faith, desire for God. This means that the discourse of spirituality has a strong connection with religion, religiosity and with religious worship. The spiritual virtues that this text considers - faith, hope and love - sit within the Christian tradition. However, the secular educational ideal of spiritual development may or may not rely on the Christian tradition for inspiration. Consequently, there has been a search for a meaningful and purely secular sense of the phrase 'spiritual development'. Modern educational usage of the spiritual dimension in education appears to emphasise what some call humanistic ideas of character such as love, forgiveness, tolerance, patience and harmony, which appear to go beyond and cannot be reduced to the materialist view of the world. This leads to an attempt to understand oneself at a deeper level - an encounter with one's inner dimension without accepting belief in the supernatural or in God. Bigger (2008), while defining spiritual values in a wholly non-religious way, speaks of some domain within ourselves which looks to spiritual well-being through the inner voice, the inner light, inner strengths and inner peace. He speaks of the holistic vision, the inner mysticism, and the feelings to transcend and transform. He believes that through a focus on various subjective experiences, meditation, wonder and awe, intuition, imagination, creativity, curiosity and reflecting on our experiences we can develop spiritually. It certainly sounds more religious than secular, but because it lacks a distinctive sense when applied to character virtues it has therefore been omitted from the framework. In addition, Carr (2004) contests whether this kind of spiritual development is a meaningful concept, although he does accept that there are spiritual virtues other than the Christian virtues of faith, hope and love. Carr (1995: 93) points to forgiveness and contrition as two such spiritual virtues. The debate on spiritual virtues reminds me of what Slavin (1942: 318) once wrote: 'Spiritual natures which should be developed in classrooms of the nation have been forgotten while educators have been rooting in the soil of materialism for the husks they may find.'

\section{The programme of study}

The Centre also developed a Programme of Study, for 11- to 16-year olds, as a guide to building character through the means of a taught course. It is designed to accompany the issues set out in the Framework for Character Education in Schools and 
is worth explaining in some detail here. Whilst there is also a primary programme, the description that follows draws heavily on the secondary programme of study. The taught sessions in the programme focus on both the theoretical and practical aspects of acquiring virtue; they are most meaningfully deployed in the context of a school that is committed to character education. Underlying the framework are at least two distinctive hallmarks of the Centre's approach to character education. The first hallmark is that character education concerns acting well, and thinking well, about developing good 'moral' sense, or practical wisdom, in the differing circumstances of students' lives. This marks a grounded and realistic approach to the cultivation of virtue. It steers us away from the notion that character education is exclusively theoretical and abstract. It also challenges the notion that character education imposes a mechanical uniformity on others. Perhaps even more helpfully, this accent on cultivating 'good sense' frees us from the egregious claim that character can be built by an instruction manual or textbook that seeks to provide cases for every eventuality. Rather, the programme provides tools and practices that enable students to experience the freedom in the moral life that is akin to what freedom of the keyboard is for the accomplished pianist. The programme provides a systematic approach to the building of character, inspired by a neoAristotelian educational philosophy, and what follows provides an explanation of its practical pedagogical implications.

The second hallmark of the Centre's approach is that engagement and dialogue with tradition are healthy and unavoidable. This also is realistic: it would be absurd to suggest that relative beginners in the moral life have reached a stage of maturity whereby they are experienced and competent enough to decide, understand or even recognise what is involved in the, at times, very thorny business of making decisions that enables human flourishing without assistance. The programme, then, responds to these concerns and assists students in the building of their character, guiding them towards flourishing and fulfilling lives. The material out of which that character is built is ready to hand: it is the students themselves. What does this mean? It means that character is made up of individual desires, emotions, feelings, thoughts, choices, reasons and actions. It means that each person must take responsibility for building their character, making what use they can of this course and its supporting materials. The programme aims to help those who are enthusiastic about or committed to this goal. To build our character is a lifetime's work, and it can never be signed off as the finished article. Whilst a number of virtues are dealt with in detail, the programme does not intend to offer an exhaustive list of virtues, still less of issues or situations that may call for the practice of virtue - such a task would be impossible. Whilst the Centre's website contains a wealth of psychological and philosophical research papers which explore what character development is and how it best takes place in educational and other contexts, this course primarily suggests the sorts of directions in which character education can be taken and its applications.

The programme is targeted at 11- to 16-year olds. Teachers may elect to follow the course all the way through, from cover to cover, or to cherry pick themes and 
ideas as the needs of their students and courses suggest. The electronic nature of the resources enables teachers to adapt and modify them to their own interests and concerns, and to the educational level of the students. Some may wish to go straight through from ages 11 to 16 ; others may choose to select a few topics and insert them into existing programmes; others may wish to cover all the issues every year, but with deepening complexity as they progress through each stage. The programme seeks to promote and inform the debate surrounding the nature, role and purpose of character education. First, though, a word of caution: any course in character virtues can only hope to offer limited outlines as to what is required or commended in the life of virtue, or the building of character. As Aristotle would have it, building character is a most inexact and messy 'science'. It will be up to the students to make the issues raised their own, and to colour, detail and reshape them with the unique story of their own lives.

The curriculum model that has been adopted in designing this course and its set of resources is inspired by Brunner's 'Spiral Curriculum'. The spiral curriculum model moves students through phases of personal experience and practice, information gathering and documentation, reflection, analysis and internalisation, and informed action; and round again, as if moving up a spiral. This enables students to look at previous learning and experience in a new light and to look at new learning from the perspective of previous experience. Growth in knowledge, judgement and practice is the purpose of such an approach. It is an experiential curriculum model, with a stress on personal engagement, ideas, reflection, refinement and internalisation, or habituation. This can be contrasted with an alternative curriculum model, one that is driven by fixed outcomes that are the product of behavioural competencies, measurement and 'tick boxes'. This latter approach would not sit well with any meaningful attempt at Aristotelian-inspired character education; although it does not necessarily exclude strategies for measuring virtue and character (see Wright, Warren and Snow, 2021). The spiral curriculum model reconceptualises the role of the teacher and makes important demands of them. On this reading, the teacher is to become a wise and sensitive guide, responsive to the needs and strengths and weaknesses of their individual students to allow for a more personalised approach to development. This can be contrasted with an alternative conceptualisation, which sees the teacher as simply a technical deliverer and assessor of a curriculum, having no real personal engagement with the needs and interests of the students, still less their personal growth. Again, this latter approach would not sit well with Aristotelian-inspired character education. Many teachers find that it was the experience of the former model (or lack of it) that first inspired them to teach. This programme supports them in that intuition and sense of vocation.

Given these demands, where might this taught programme sit in an already pressurised school curriculum, subject to competing initiatives? In at least two places: it would work well either as a stand-alone, or as a 'little and often' part of the school's pastoral programme. Perhaps, unlike some approaches to moral or 'values' education, the emphasis of Aristotelian-inspired character education is overwhelmingly on developing sound moral judgements (good sense), 
action, personal reflection and growth into ethical maturity. A combination of pedagogical approaches is therefore used throughout the programme. Some of the resources are shaped around a deductive and conceptual approach, with students coming to understand what the structure of a virtue is, then thinking through how these principles apply to the facts of their lives, and how they can use those facts to practise the virtue. Other resources adopt a more inductive approach, beginning with specific issues, working outwards to the realities of the students' lives, and then onto the underlying principles. Both are necessary, and both can be harmonised. Amongst the challenges teachers have faced in character education to date is the development of a mutually intelligible discourse - many students simply do not have the language of character education or the virtues. The programme therefore focuses on building virtue knowledge, virtue reasoning and virtue practice for some classically recognised virtues. (This forms the more conceptual part of this text and is found in resources that elucidate specific virtues, e.g., the virtue of courage, or virtue of self-control, etc. that set out the Centre's framework of specific virtues. Whilst this part is more conceptual and deductive, there are plenty of opportunities for application.)

We can begin to develop a moral pedagogy by asking, 'What is virtue knowledge about?' It is about acquiring and understanding the (sometimes) technical language and concepts associated with virtue. The programme consequently assists students to learn about the issues for each virtue: what those who have this virtue can do particularly well; what the benefits of acting out this specific virtue are; which situations may be appropriate for the acting out of this virtue; which emotions or desires and feelings may be alerting us to practise this particular virtue; how to think through and construct dilemmas and scenarios, which illuminate how the virtue might best be exercised. Of course, knowing about the issues surrounding the virtues is not sufficient for being virtuous - it may not necessarily change our actions. We may, for instance, know what courage is in general, but this does not necessarily make us courageous in those situations that call for courage. We need to move from knowing what a virtue is to how and when we should practise it. For this, we need virtue reasoning. What is virtue reasoning about? It is about making reasoned judgements about when and how to act well. This includes the ability to explain differences in moral situations, such as moral dilemmas. The emphasis in acquiring judgement is reflective and allows for each individual to make their own decisions about how to best give expression to the virtues in situations pertinent to them. Virtue reasoning is, for example, about taking our understanding of courage and knowing how best to give expression to it when we find ourselves in situations that call for it. Furthermore, students need to learn other issues that might attend each virtue: 'What are my basic dispositions and inclinations in the light of this virtue?' 'Is there a pattern to my emotions and desires when in this situation?' 'When and how well have I practised this virtue in the past?' 'What are my circumstances, options and choices for practising this specific virtue?' 'When can I practise this virtue in the near future?' 'Where is the "Golden Mean" (the ideal, most reasonable, morally good, set of actions, given the 
circumstances) for me?' 'Which actions will give the best expression to this in a self-identified scenario?' 'Which actions will look like I am falling short of the virtue?' 'Which actions will look like I am over-cooking the virtue?' Both virtue knowledge and virtue reasoning are linked to the promotion of virtue practice. We may, for instance, acquire some cognitive understanding of what would be the desirable virtue to display in certain circumstances, but be unable to translate this knowledge and reasoning into virtuous action on a stable basis. Virtuous practice therefore enables us to give expression to virtue in desirable, recognisable and observable attitudes and action.

Self-examination is an important component of 'virtue practice'. Virtue practice demands that I be courageous in situations that I identify as calling for that virtue. It also demands that I am able to examine how courageous I really was when in a situation that called for it, and how I might continue to build on my strengths and challenge areas of failure in relation to the virtue. Students, for instance, are invited to build their own understanding of virtues, such as gratitude and compassion, and of how best to exercise them in their lives. This makes for some interesting applications. For example, they are encouraged to identify the virtues that they need to cultivate in order to flourish once they enter the world of work. Those aspiring to journalism, for instance, may wish to cultivate the virtue of truthfulness; those aspiring to medicine, the virtues of compassion and care; those aspiring to teaching, patience and humility, and so on. This enables students to practise the conceptual and practical tools required to continue the project of growing in virtue beyond the time they leave formal education. Schools may, for instance, wish to develop greater self-control, resilience and stillness in their students, especially in the face of substance abuse or stress issues, or they may wish to tackle virtues connected to justice and self-control, raising the social awareness of their students. Good schools will know the needs of their students well.

This is perhaps easier to understand if we consider how we come to acquire and practise 'virtues' - which we (and our students, no doubt) already do to varying degrees. Put simply, the way to build our character consciously and systematically goes something like this: First, we have to recognise that we are in a moral situation. A moral situation is a situation that calls for us to do something we ought to do. To do 'that thing that we ought to do' requires the practice of a virtue. Second, this situation triggers emotions, desires or feelings in us. Sometimes these can be very strong, sometimes they can be very weak. We have to be able to specify and identify the emotion or desire that the situation has triggered in us. Third, we need to identify the virtue(s) that can educate our specific emotion(s) towards realising the good in the situation we are in. We 'realise the good' through words, actions and deeds - by doing the right thing, at the right time, in the right way and for the right reasons - and hopefully, but not always, with the right consequences. Stages one to three are covered by the virtue of knowledge. Fourth, we need to think through our options and weigh up the morally relevant features of a situation. We need to think about how we can practise or give expression to the virtue(s) that correspond (s) to the emotion(s) or desire(s) that are stimulating us or failing to stimulate us. This 
is where the virtue reasoning comes in. These practices need to tread a careful path between 'overdoing' and 'underdoing' it, to give the very best expression to acting in a way that is in line with the golden mean and thereby educate and shape our emotions - not eradicate them. Fifth, we need to reflect on how well we handled the situation, looking at where we might be strong and where we still might need to grow or to practise the virtue. We need to look at our emotions, desires, our pleasures and pains. Put less theoretically (but perhaps more meaningfully), we can ask: 'What is the question that elicits a "virtue" response?'

Virtue knowledge, reasoning and practice are three components of character on which an evaluation might focus. Virtue knowledge and reasoning can be combined to be termed virtue literacy. It is easier to successfully evaluate development in a student's virtue literacy than their virtue practice. 'Virtue literacy' is a helpful term that can be defined in two stages. The first is developing a knowledge and understanding of virtue terms. The second is developing the ability and the will to apply the virtues to real-life contexts. Virtue literacy consists of three interrelated components: (1) virtue perception; (2) virtue knowledge and understanding; and (3) virtue reasoning. The first component is concerned with noticing situations standing in need of virtues. The second component involves acquiring a complex language usage through familiarity with virtue terms, albeit knowledge of the virtues themselves will not necessarily change behaviour. The third component concerns making reasoned judgements, which includes the ability to explain differences in moral situations. This emphasis on acquiring judgement must be reflective and so allow for the empowerment of the ethical self through autonomous decision-making. The determination of whether a child is virtue literate should not be reduced to simple outcomes but should consider all three components. Children need to be persuaded of the moral force of acting virtuously. Schools need to provide opportunities for children to exercise the virtues in practice as well as encourage a rich discourse of virtue language, understanding and reasoning. Wright (2014) offers a strong case for a taught course in character education as a means to provide stimulating and structured support in helping students to think through how to become:

- practically wise, educable, far-sighted, open-minded and resolute, rather than pertinacious, or impulsive;

- courageous, rather than cowardly or over-confident;

- fair-minded and just, rather than easily exploited, or avaricious and selfish;

- $\quad$ adept at a mastery of self, rather than insensible, or self-indulgent;

- studious and intellectually curious and serious, rather than cynical and indolent, or intellectually superficial;

- patient, peaceful and well-focused, rather than bored (and boring), or impatient and easily distracted;

- courteous and pleasant, rather than rude and egotistical, or obsequious and malleable;

- witty, rather than cold and sarcastic, or buffoonish and silly; 
- even-tempered, rather than a 'push-over', or prickly, and over-sensitive;

- truthful and straightforward, rather than cringingly self-deprecating, or boastful;

- grateful, rather than ungrateful, or unctuous and sycophantic;

- compassionate and kind, rather than callous and cruel, or condescending or insincere;

- generous, rather than mean-spirited, or wasteful;

- humble, rather than arrogant, or servile and obsequious;

- tolerant and forgiving, rather than narrow minded, vengeful, self-righteous and bigoted, or overly indulgent and complicit in the face of wickedness and vice;

- high-minded and conscionable, with well-grounded self-esteem, rather than stunted by low self-esteem, negativity and hyper-criticism, or with an over-inflated and ill-founded sense of self;

- a stronger friend and to emulate worthwhile qualities in others.

Parents would no doubt agree with most of these goals for their children. Parents are attracted to what might be called common-sense virtue ethics; that is, parents want their children to be happy and expect teachers and schools to guide their children to virtue, to provide them with reasonable rules that act as boundaries for their children's actions, and to perhaps even teach them how to live a flourishing life. The goals above are essentially about a growth in virtue, and any good character education programme would teach the 'how' of this growth in virtue. The Jubilee Centre's programme is really an education that cultivates virtue that is guided by reason to lead a life directed towards the good. It seeks to encourage students to desire the good by increasing their motivation to do the good while also gradually developing their ability to do the good. Acting on our beliefs about the good strengthens those beliefs and increases the likelihood of us repeating good actions. The question is not whether schools teach students how to live, but how they do so through what they teach and the environments that they create. There are many dimensions of school life that are constitutive elements of character virtue formation; from the teaching and learning strategies, to the ethos and environment, to the positive example of the teachers, to the goals and mission of the school, and even right down to the architecture of the school itself. The content of the Jubilee Centre's programme of study provides a comprehensive range of teaching and learning strategies, including: service learning in the community, co-operative learning in teams, classroom discussion and debate, drama and literature, moral dilemmas and project work, which all speak to these dimensions that model desirable character virtues or offer opportunities to understand and practise the virtues.

\section{Secular to Christian character education}

Using Aristotelian and Thomist language and philosophy, we could argue that this secular programme produced by the Jubilee Centre, located within the right Christian context and practice, could be employed to help students come to know 
who they are and to know what to do in order to become fully the beings they are meant to become. As C. S. Lewis (1989: 89) said: 'I think that for young people today, we had better make them good pagans before we make them good Christians', by which he meant that pre-Christian pagan insights could assist in the preparation to receive the Gospel. Secular students learn through their own free and self-determining choices that shape their lives. You could argue that what we have discussed by way of virtue and character education within the Christian tradition could easily be rooted in the theologically informed educational philosophy of Thomas. For Thomas, education is the initiation into the life of reason and this reason influences the formation of character because the student is more than simply a mind - Thomas looks to the whole human being. It is therefore worth examining the Jubilee Centre's programme of study through the lens of an Aristotelian-Thomist philosopher, Mortimer Adler (1982), who produced his own Paideia Proposal: An Educational Manifesto in 1982. Mortimer adopts a similar approach to Maritain (1943) by viewing education as both lifelong and not restricted to institutions of learning. Indeed, while all children are educable, Adler sees youth as the greatest obstacle to becoming an educated human being. Schooling is only the preparatory stage of education that prepares the young to continue learning in later life by giving them the skills of, and the love for, learning. Education proper comes later than schooling.

Like Adler's definition of education, the programme of study discussed above is a process designed to change someone for the better by helping to produce a person to think and live well. Education is undertaken to change us, and we are changed by ourselves or by others. This process is always intended for the better, for whatever makes us intentionally worse as human beings cannot be considered an education worth pursuing. Adler sees change for the better, brought about by the process of education, and as something that is relatively permanent in our character. He proceeds to a consideration of the intellectual and moral virtues (the programme added the civic and performance virtues which Adler largely assumes in his scheme). Adler returns to the natural capacities of the human being and sees in them two powers that justify our efforts in education: our rationality and our free will. These are the two hallmarks of a human being and education's role is to improve upon them. Adler argues that the means to this improvement are through the intellectual and moral virtues, since the betterment of a person consists in the formation of good habits, meaning virtues, for the good. As Adler (1982: 75) states: 'Children should be prepared and motivated to make themselves the best human beings they are capable of becoming.' Parents, teachers and schools therefore need to challenge their children to fulfil the high expectations they have of them. All of this educational philosophy, focusing on the whole person and the development of their character, corresponds well with the Jubilee Centre's goals for its programmes of study.

Thomas was most certainly innovative in his approach to education and much of what he recommended for teachers could be accepted today. He thought that education has a benefit to the individual and society, and that the educated 
individual has a duty of service to society. For Thomas, learning could be initiated by the teacher, but the teacher should build their teaching on the gradual development of the student's human nature. Teaching is to be clear, logical, coherent and precise if it is to be successful. It must also appeal to the minds of the students and include reflection as well as questions and answers. Students are to be taught how to debate and discuss the content of the teaching, and teachers must respect the freedom of the students in their learning.

Both the primary and secondary programmes of study, together with the Framework, have influenced many schools. The programmes have attracted different levels of interest from both private schools (including Eton and Harrow) and those in the state sector. The different levels of Centre engagement have ranged from schools like Ramsey Secondary School, which has launched a Virtue Project promoting character virtues in the school ethos, to Yeading Primary School, which has embraced a more comprehensive approach using the Jubilee Centre's virtue literacy ideas. Staff at Yeading School have written a book about its efforts in virtue and character education titled Whole School Character and Virtue Education: A Pioneering Approach to Helping All Children to Flourish. A number of Academy Trusts, such as the Avanti Schools Trust, have also employed the language of character virtues to describe their vision of education. In addition, the Roman Catholic Diocese of Leeds has produced a report and guidance for Catholic schools based on the Framework. Teachers are more than capable of determining the most effective ways of turning ideas about character virtues into classroom reality. Within a Christian context this becomes even more explicit because those that have a Christian faith will ask: 'Who are we called to be and do?' The answer, for the Christian, is beings who love, beings who love as Christ has loved us and beings who shape our decisions and actions in accordance with this Christian love. Christian schools are thus in a unique position to discuss character and virtues. As Lickona (1994: 329) says: 'Traditional religion tells us who we are, why we're here, and where we're going.' The telos or end of teaching and learning is to enable the student to attain the state of beatific perfection. In this sense, Christian education is concerned with the proximate means to happiness in the here and hereafter - namely, the virtues. Because secular education promotes a form of reason without faith and a formation without religion, Catholic schools in this scheme would need to place the Christian faith at the centre of their teaching rather than attempt to constrain their faith by compromising with secularism.

The danger of a secular framework for Christian character virtues is its easy attractiveness to Christian schools. The dominant discourse in modern education revolves around being egalitarian, inclusive, liberal and progressive, and these ideals are often conflated with certain charitable ideals and practices within Christianity itself and with the idea that all reasonable people ought to aspire to and embrace these ideals. In addition, many Christian schools are eager to promote themselves as places of academic attainment and 'good' behaviour, and some even see organised religion as a culturally tainted source of virtue. This results in education being viewed as independent of theology and a greater emphasis being placed on the 
school part of the 'Christian school'. It leads to the separation of the natural or classical virtues from the theological virtues with little reference to the divine in school mission statements, leading in turn to a non-theological account of education. Such Christian schools will still encourage the practice of certain classical virtues, endorsing 'you ought', but without giving a full explanation of why. Consequently, virtue gradually becomes a prejudice relative to some educational philosophy, cultural moment or secular mission. In contrast, an explicit Christian theology that guides pedagogy helps us to know the good and the virtues that enable aspiration to them, if not achievement of them. Mission statements for Christian schools need to avoid multiple and conflicting interpretations of what character virtues they are supporting, otherwise they may find that teachers have difficulty in explaining how they translate into practice. As this practice is best understood as a Christian pedagogy, it is worth exploring its origins.

\section{Christian pedagogy}

In the Greco-Roman world, pedagogy meant to care for and about someone for whom you had responsibility. A pedagogue was generally an intelligent and trusted slave resident within a rich household. Pedagogues were therefore distinguished from teachers, who taught particular subjects. Pedagogues accompanied the sons of the rich and had certain duties: looking after them in the streets, seeing to their wellbeing, caring for them and sitting with them while they were being taught. They were pais-agogas - child-tenders there for their charges. Nevertheless, these pedagogues were also teachers in that they were more than simply custodians of children and adolescents; rather, they were their companions, responsible for discipline and moral guidance through their example and conversations. These individual slaves were significant figures who were far more important than subject teachers for the formation of character (see Arthur, 2020). Paradoxically, slaves who were not considered to have any excellences/virtues in Greek society were responsible for teaching the virtues to the younger family members. Pedagogy therefore means to lead a child, and it values the relationship between the pedagogue and the learner. Clement of Alexandria wrote The Pedagogus (c. 198) within this classical world; a world which began to lay out a Christian approach to pedagogy that focused on character formation. This early Christian work was holistic in that it addressed the intellectual, physical, moral and emotional development of Christians and represented a guide for the formation of Christian character through a training in the virtues. Christ is presented as the educator who moulds the character of those who believe in Him, albeit Clement stresses the teacher's role in adapting his teaching to the readiness of the learner. Augustine, in his De Catechizandis Rudibus (c. 403), advises that the teacher must keep his teaching brief and simple, to know their audience (and themselves) and that they should teach from history - meaning that they should provide concrete examples to illustrate real life points. This was not intended to teach the deep meaning of Christian moral theology, but simply to teach the key practices and beliefs of the Christian approach to virtue. This was 
mainly achieved through preaching, which was a persuasive and educational activity, and employed a range of teaching techniques to engage the learner and inculcate moral precepts. Among the variety of approaches that exist in Christian pedagogy, the best include presenting a concrete case that is linked to the student's experience. As only a tiny minority attended schools, the population as a whole was educated in the culture they found themselves, and we need to recognise that Christian culture, not schools, was the formative dimension. Indeed, there was no attempt to establish Christian schools in the early Church as Christians, who had access to schools, simply accommodated the pagan education available and taught the religious and moral virtues at home (see Marrou, 1956: 317-318 and Holder, 1992: 396). However, Christians were aware that a pagan education, in content and in pedagogy, was no guarantee of an improved character - something that is clear from Augustine's Confessions.

Too often today pedagogy is simply reduced to a narrow consideration of teaching techniques - pedagogy is seen in instrumental terms. But teaching is just one aspect of the practice of pedagogy, which is richer and has an aim of human flourishing. As Bruner (1996: 3) observed, 'Any choice of pedagogical practice implies a conception of the learning.' Because pedagogy has an understanding of human nature and even a telos, in any context, its chief purpose is to facilitate the moral growth of students. Yet most works on Christian pedagogy are theoretical in scope, and while there is also much work still to do in developing moral theory in the field of virtue ethics, there is little attention given to its practical application in concrete educational situations. Teaching is an ethical and virtue driven practice that depends on the excellence of the teacher's character. The moral growth of students therefore is congruent on the practice of the virtues in the teaching process, particularly in the teacher's display of compassion, trust and empathy in their teaching.

This idea of telos is well illustrated by various modern conceptions of pedagogy that seek to radically transform students and which make no claim to political neutrality. The dominant educational discourses produce a range of pedagogical understandings that include feminist, critical, social justice, neoliberal, activist and cultural expressions, meaning that there is hardly a consensus on definition. Take, for example, Grande's (2010: 199ff) 'red pedagogy':

For teachers and students, this means that we must be willing to act as agents of transgression, posing critical questions and engaging dangerous discourse. It means calling into question the hegemonic discourses of unilateralism, monoculturalism, English-only, consumerism, nationalism, and free-market fundamentalism that construct education as a privilege and consider instead the implications of multilateralism, multiculturalism, multilingualism, contingency, and coalition that reasserts education as the right of a people.

One of the first advocates of a critical pedagogy was Paulo Freire, the Brazilian educationalist and author of Pedagogy of the Oppressed (1970). His text had huge influence on progressive education, but few realise that his advocacy of a 
'humanizing pedagogy' was influenced by his radical Catholicism and his telos of each person developing their full humanity through community practices that results in 'mutual humanization' (see Rhodes and Lysaught, 2020: 110 and Modero, 2015). Maritain (1943: 3-4) had written two decades prior to Freire a more detailed and sophisticated argument for 'the perfection of the humanity of human beings', but because it was posited in Christian Thomist terms it was largely ignored by the secular educational world. Nevertheless, those who embrace a radical critical pedagogy, such as Freire's idea of praxis, often unknowingly work out of a tradition with strong ties to religious faith. This leads to the question of what a genuine Christian pedagogy would look like.

Christian theological frameworks are common, but little attention is given in Christian scholarship to a pedagogy of virtue and character, resulting in pedagogies that are, at best, shallow. We have already seen how MacIntyre (1981) believes that in our modern world there is no shared view of the telos and a rejection of any notion of virtue. MacIntyre thus advances the idea that virtue language makes sense only where we recognise the formative role of communities of practice in creating virtuous agents. He says that through experiencing a community we understand what the good is because virtuous actors are not born, they are made. Virtue pedagogy is the construction of character and therefore any education worthy of the name has to be formative. However, MacIntyre (1964:1) is pessimistic about the role of schools in virtue formation. Nearly 50 years ago he said: 'I shall argue that the moral content of our educational system is simply a reflection of the moral content of our society' and by this he did not intend a positive evaluation of the content of society's virtues. He continued: 'the task of the educator is to attempt to stand against a current which will probably overwhelm him', and, 25 years ago, MacIntyre famously said: 'Teachers are the forlorn hope of the culture of Western modernity.' MacIntyre believes one can only talk about the virtues if a teleology is in place and that schools are simply an instrument of the larger society. Schools are limited in what they can do and have few practical opportunities to experience practising the virtues, making it difficult for schools to foster the virtues. The moral education they provide is necessarily open and thin if they are to claim any acceptance in a divided and heterogeneous society. Real education, for MacIntyre, takes place in the form of participation in a range of social practices within living traditions. Clearly, the Christian tradition is a living tradition within which people participate in practices and so acquire virtues. Indeed, the tradition was the principal way Christians were inducted into the Christian life.

Thomas, in his treatise on education, De Magistro ('The Teacher'; 1256-1259), stressed both the importance of the student's self-activity (normally understood as self-expression today) in the educative process, but also the specific role of the teacher developing both intellectual ability and building the character of their students. The most important agent in the educational process is not the teacher, but the student. The teacher conveys worthwhile knowledge to the student's mind by causing him to know what he previously had the capacity to know before. Two ways of acquiring knowledge are outlined by Thomas. In the first, the student 
acquires knowledge of the unknown through 'discovery' while in the second, the student acquires knowledge through the assistance of the teacher in instruction. Therefore, what is required for pedagogy to advance is a student who seeks knowledge and a teacher prepared to aid the acquisition of this knowledge by the student. (E. Gilson's (1953) excellent lecture on the 'Eminence of Teaching' explains Thomas's understanding of teaching in surprisingly practical terms for a philosopher and is therefore worth reading.) Maritain (1943) uses his Thomist philosophy to reflect on a general theory of education by focusing on four areas: (1) the goals of education, (2) the role of the educator, (3) the role of the school, and (4) what should be taught. Maritain began with an evaluation of the question 'What is the person?' and consequently established an approach to pedagogy centred on the learner as a person that laid the foundations for a Christian pedagogy. He found much that was praiseworthy in modern progressive pedagogical approaches, but insisted that the theological and spiritual dimensions of pedagogy were missing. Only theology and doctrine, for Maritain, provide the unifying principle for a Christian pedagogy, and he sees the teacher as a companion, accompanying the learner to help them become who they are. Any good teacher will direct their teaching to both take account of the student and have some understanding of the nature of the human being, their end and their flourishing. In summary, the goal of Maritain's (1962: 48) educational philosophy was to liberate the mind to attain truth that could be achieved through a liberal education. This liberal education equipped the mind for truth, helped the learner become 'capable of judging according to the worth of evidence' and also advanced them in wisdom together with some understanding of those things that bring them 'intimations of immortality'.

Teaching for Thomas was only part of education, since education had a broader meaning, dealing essentially with the growth of the child in virtue. In the Commentary on the Sentences (1254-1256), Thomas gives a definition of education as 'the advancement of the child to the state of specifically human excellence, that is to say, to the state of virtue' (see Walters, Arthur and Gaine, 1999: 33). The goal of education for Thomas is a life-long process of learning how to return to God and this returning to God cannot be achieved without Christ. This is why Thomas believes that the best teaching of all, in terms of content, is the teaching of Christ. There is certainly an integration of faith and learning because Christian pedagogy is informed by Christian theory and practice. This is why the influence of Christianity ought to be evident in considerations of the purpose of education, the goals of educational practice, the content and methods employed, the motivation of teachers, the quality of the school environment and much besides. Education provides targeted interventions that can strengthen moral character; a kind of training for a certain competency in virtuous character, meaning that virtuous actions can be established as part of our character in four different ways. First, we can be naturally inclined towards certain virtuous behaviour patterns. Second, through repetition we can eventually gain the ability to perform virtuous actions. Third, we can practise rational deliberation so that we become more disposed towards practising virtuous actions. Fourth, within the Christian context we can 
perform virtuous actions through infused virtues which cannot be acquired solely through repetition or practice.

A Catholic pedagogy must therefore be animated by a Catholic understanding of human nature so as to enable the learner to seek the truth and critique the prevailing culture around them. A Catholic pedagogy presents faith as a real choice. As the Catechism states:

Catechesis is an education in the faith of children, young people, and adults which includes especially the teaching of Christian doctrine imparted, generally speaking, in an organic and systematic way, with a view to initiating the hearers into the fullness of Christian life.

(CCC n. 5)

Catholic homes and schools are therefore places of formation and evangelisation they are places of ecclesial experience where the faith is publicly modelled in words and actions, and where learners engage with the important questions of life. Groome (1996: 118) states that the essence of Christian pedagogy involves engaging "the very "being" of ... students, to inform, form and trans-form their identity and agency - who they are and how they live - with the meaning and ethic of Christian faith'. This is a transformative model of pedagogy that provides students with opportunities and experiences to activate the spirit of God dwelling within them. It requires that Catholic education has depth and be unambiguous - certainly not promoting a vague religious awareness. However, it cannot be reduced by intellectual assent to a set of doctrinal propositions because the witness as Christians is only possible in light of communion with the experience that is the Church - the Church being a community of practice. Catholic schools and families are not always sites of this ecclesial communion. However, Christian pedagogy encourages human flourishing and gives emphasis to accompanying the student on a journey where 'being with' and relationship are paramount. This kind of pedagogy is vital for character formation.

Character virtues cannot be learnt fully in a classroom as they require the experience of their practice in community contexts to develop them. As Carr (1991: 9) explains:

the fundamental moral virtues cannot be learned in any context of socialization or education apart from the example of those parents, teachers and friends who are able to exhibit to some degree how they work for the good in human life.

The use of literature, narrative, stories, moral exemplars, instruction, traditions, role-play, dilemmas and ethos as pedagogical devices requires practice since the virtues are learned by habituation. We can teach about the virtues and offer students definitions and a vocabulary of what they entail. We can teach what the virtues look like and how to recognise them in real-life situations. In the end, however, we need to offer concrete opportunities to practise them with 
corresponding evaluative feedback from teachers or parents on the exercise of these virtues. Students require experiences that model the virtues within supportive atmospheres because observing virtue in action can motivate the desire to be virtuous, students often identifying with the model. McDonough (1994: 77) helpfully describes the Aristotelian view of the use of exemplars, which Thomas appears to endorse, by placing the emphasis on 'the importance of rich exemplars such as those found in literature, enables children to develop and exercise a capacity for moral judgement that is sensitive to the complexities of particular moral judgements'.

The moral formation of students is one of the foundational goals of an education that seeks to form character imbued with a strong ethical compass. As we have seen in the previous chapter, Thomas's moral theology incorporated substantial elements of Aristotle's Ethics. One of the central themes that Thomas developed was whether there exists a goal in life by which we can determine the rightness of our day-to-day actions. Both he and Aristotle agreed that there is such a goal that can be discovered through reason and only achieved in living a virtuous life. They agreed that it was possible to move from an unsatisfactory initial state of character to one that is fully developed - in other words, they offer a teleological view of human life. Thomas combined Aristotle's ethics of happiness based on human nature with an ethos of Christian love.

Jensen (2013: 84), following Thomas, speaks of a continuum of character that ranges from the extreme of evil to the extreme of perfection. On this continuum he distinguishes (but does not limit it to) a fourfold division:

On the end of extreme evil we have the vicious person, in whom reason and the will habitually follow the errant desires of the passions. Next we have the weak-willed individual, who still retains the correct judgement of good and evil, but does not often follow the judgement, for he sides with his desires. Next we have the self-controlled individual, who has errant desires but resists them. Finally, we have the virtuous person, who follows reason both in his choices and in his desires.

Of course, most of us are somewhere between these two extremes - we are weak-willed or self-controlled, but not yet vicious or virtuous. None of us, whether Christian or non-Christian, ought to resign ourselves to this state. Character formation in the Christian tradition is essentially about improving our state or directing us to the perfect state.

\section{Christian education in character}

There are many who think that the relationships and connections between Aristotelian and Christian ethics are obvious to such an extent that all Christians, as well as everyone else, should consider adopting them in their educational 
approach. However, it is not the case that Aristotelian ethics are self-evidently compatible with Christian understandings of virtue, or that they are sufficient to adopt without major adaptation. If one believes that everyone should adopt them irrespective of their religious beliefs, then there is clearly no need to explicitly appeal to Christian ideas. Too often people use biblical texts that do not relate to the ethical points they are making, while others assume too much about the connections between Christian and Aristotelian ethics. Connections between the Bible and virtue are also not always obvious, and it is better not to assume an easy connection. Kotva (1996: 50) cites Greg Jones, who said of his colleague Hauerwas: "his discussions still tend to be "bilingual"; talk of character and the virtues here, then talk of sin and grace and discipleship and Jesus there, without carefully working out whether and how these vocabularies are related to each other'. He claims that Hauerwas assumes discussions of the moral life connect with his understanding of character and virtues, when, in fact, it is not clear that they do. Nevertheless, there are connections, and the Aristotelian ethical approach can help express and explain many moral convictions of the Christian tradition.

Character has played a central theme in Hauerwas's ethical and doctrinal thought, and he advocates that an understanding of our character depends on an understanding of our history and past actions. In his Character and the Christian Life, he sets out to investigate how the Christian moral life is determined by Christ and attempts to show what difference Christ makes to our character. Good works, he believes, are the outer signs of character that is changed by God's grace. Therefore he argues that good works result from a sanctified character, as he writes: 'To be sanctified is to have our character determined by our basic commitments and beliefs about God ... Christian character is the formation of our affections and actions according to the fundamental beliefs of the Christian faith and life' (Hauerwas, 1995: 203). In this scheme of things, Christ is not simply a guide to virtue but the ultimate end of human action - the human telos is seen in Him. To be sanctified is therefore to live according to God's design and purpose for us, and we change our character through God's grace. As Gaine (2015: 99, 100) explains: 'according to Aquinas, grace had the role of elevating human beings above the limitations of their nature' and human beings have 'a twofold end to be pursued, one natural, proportionate to the active capacities of nature and pursued in this life, and one supernatural, which transcends such capacities, and is granted to us only in the next life'. The previous chapter has shown that Thomas did not develop a comprehensive philosophy of education but rather discusses education within the framework of his major theological and philosophical writings. He also importantly does not confuse ends and means, but insists not only that the end is the beginning, but also that the end measures the means which must be taken if the end is to be attained' (see Slavin, 1937: 22).

While grace makes our efforts and moral growth possible, it does not eliminate the need for effort and growth on our part. We become virtuous through Christ by becoming like Christ. The first role of a Christian school therefore is to create an environment or culture that enables students to build and deepen their 
relationship with God. The second role is to foster an academic culture aimed at the pursuit of truth, and the third role is to actively promote growth in Christian virtues. The Christian school has the obligations to teach an understanding of moral virtues, to prescribe some commitments and norms for its students to learn, to justify these norms and to describe how they fit into our Christian lives. The norms should state what character traits and actions are praiseworthy and are justified by showing how these traits are conducive to a Christian life and a meaningful personal existence in relation to God. This integral formation of the human person seeks to form in students a clear idea of the meaning of life, which is the development of faith-filled Christlikeness. Christ is the supreme model and example, although we can look to others who are already flourishing as examples to emulate. As Pieper (1954) said, we need to seek 'to attain the furthest potentiality of his nature' even if we are never fulfilled, never completed in this life. According to this perspective, the Christian school must have in view the living of life more than the mere learning of a subject. We need to see the student in community with their human capacity for virtuous action - that is, a capacity to make decisions on the basis of self-deliberation, planning action on the basis of that decision, and being responsible for those decisions and actions resulting. We need to develop a belief in the capacity of human reason to freely arrive at the truth within a Christian theory of human fulfilment that describes the goals towards which the virtues lead; a theory that helps produce practical moral judgements based on beliefs and experiences instead of just rules and principles. We need to view human reason as always in the service of human flourishing.

An education in Christian ethics is not fundamentally about obligations, laws and rules, but rather it is an initiation into a way of life capable of making the student good and therefore happy. No one is naturally virtuous, and so we need to develop a firm, stable and predictable quality of being and acting, even if we are inclined by nature to be so. We acquire virtue by acting in a certain way over time. You could say that the Christian school must train its students for a life of happiness, joy and flourishing. While laws and obligations are important, they should not stand in the way of God's desire that we should educate for happiness. The opening lines of the Sermon on the Mount in Matthew 5 begin with: 'Happy are those who ...', and in these Beatitudes Christ praises people - not simply what they do. God wants our happiness in Christ, and He wants us to flourish and to share His joy. Human happiness is nothing other than the perfect good, and the virtues aid this good. Happiness is often associated with wealth, bodily health and fitness, popularity and prestige, pleasure and celebrity, honour and fame, but the Christian school offers a different understanding from that of which happiness consists. These are, of course, subject to chance and circumstance, since we can lose them or gain them. The Christian life is a life characterised by kindness, compassion, humility, generosity, justice, truthfulness, courage, forgiveness, mercy, consideration, benevolence, honesty and fellow feeling. It is a Christian life in which we are what God wants us to be, and we share this life with others through our friendships and within our communities. Indeed, we acquire these virtues in 
communities, such as in a school community, since the virtues grow in formative relationships. The virtuous life requires certain kinds of relationships, which means that virtues, friendship and community are inextricably connected. The more we know the true goal of life and possess the virtues the more we are able to reach a state of happiness.

Education in the virtues helps us understand our obligations to others. It helps us become skilled at addressing controversial issues as well as in understanding moral traditions and theories. However, education in the virtues is too restricted and narrow to count as a complete education in the moral life. That requires education to be a more dramatic and challenging effort in order that students may achieve the fullest possibilities of being human beings. Rather, virtues help us develop our potential for excellence; they have humanising qualities. It was the late Herbert McCabe (2005: 9) who put it thus: we study ethics in order to learn 'how to be good at being human', and, in following Aristotle and Thomas, the business of ethics is not simply to teach people how to 'talk about being good' but, more importantly, 'to make people good as well' (2005: 49). Thomas believed that being brought up in a Christian family with things pertaining to Christian life allows one to more easily persevere therein (ST III 68.9). Students need to feel good about life; a life of purpose and meaning, a life full of joy and happiness. They need teachers who can help them grow in knowing, loving, and enjoying God. As Hauerwas (2010: 95) notes: 'there is no substitute for learning to be a Christian by being in the presence of significant lives made significant by being Christian'. As Ozolins (2013: 9) observes:

For Aquinas, teaching is connected with the Divine, since he argues that though human beings are able to teach, they do so in a secondary sense and that it is God who primarily teaches. This is because God is the source of all being and is the light at the heart of our being. In the learning process, a key feature of Aquinas's account builds on the nature of illumination, which is to say an understanding of what is taught that enables us to see how what we have learnt connects to other things. Ultimately, these connections lead us to Wisdom, which is to say God, and for Aquinas wisdom in its different forms is the central aim of all teaching and learning.

Thomas saw teaching as a vocation, essentially a calling by God to serve humanity that is motivated by a love of truth, God and others. On teaching, Thomas offers us four major pedagogical proposals that would command some support from many modern teachers (Mayer, 1929: 92).

First, learning takes place when a topic arouses the interest of the student and when the student is willing to learn. The teaching role is to facilitate the learning activities and guide the student to truth - truth here being associated with coming closer to knowing God. Second, the teacher will have mastered knowledge in order for them to be able to guide with some authority. Third, the teacher will know that the reflective processes leading the student to gain knowledge will determine the methods of instruction. These methods will include question-and- 
answer techniques and use of symbols as tools for instruction, and the teacher will be clear in presentation, appealing to the mind of the student. Fourth, the teacher will respect the student's freedom while helping them to avoid error.

Catholic education more specifically seeks to encourage in students an intimate friendship with God and an attraction to the good. As John Paul II wrote in Veritatis Splendor (1993: n9): 'To ask about the good, in fact, ultimately means to turn to God, the fullness of goodness.' Christian ethics is an ongoing educative process in what constitutes an authentic happiness, and this process helps students discover for themselves the life that is most conducive to happiness. Christ is at the heart of this pursuit of happiness, for it is essentially a life of discipleship that 'emphasises the primacy of God's agency over human agency, of grace and gift over personal autonomy and achievement' (Wadell, 2007: 21). It is these grace-infused virtues that change our dreams, our feelings, our emotions, our intelligence, our reason, our imagination, our perceptions, our freedom, our choices, our memories and which work together to help us achieve the good - to grow into the telos of human beings.

Pope Pius XI, in his encyclical Divini Illius Magistri (The Christian Education of Youth) (1936: para 32), stated the objective of Catholic education clearly: 'the true and perfect Christian ... in other words, to use the current term, the true and finished man of character'. The Second Vatican Council's Declaration on Christian Education (Vatican Council II, 1965: para 1) duly reaffirmed:

True education is directed towards the formation of the human person in view of the final end and the good of that society to which he belongs and in the duties of which he will, as an adult, have a share.

The emphasis on formation and the 'final end' of being human are fundamental. Further Vatican documents, such as The Catholic School (Congregation for Catholic Education, 1977: para 34), place Christ and the Gospel at the centre of the whole educational enterprise. As Pope Benedict XVI (2010) says:

the task of the teacher is not simply to impart information or to provide training skills intended to deliver some economic benefit to society; education is not and must never be considered as purely utilitarian. It is about forming the human person, equipping him or her to live life to the full - in short it is about imparting wisdom. And true wisdom is inseparable from knowledge of the Creator.

Pope Benedict is making clear that education is not merely the production of knowledge, understood as information, nor is expertise simply having more knowledge or learning simply acquiring more knowledge.

The Catholic School affirms that the Church's mission in education is 'to insure strong character formation' (1977: para 11). The Catholic School on the Threshold of the Third Millennium (Congregation for Catholic Education, 1997) offers the following critique: 
The fragmentation of education, the generic character of the values frequently invoked and which obtain ample and easy consensus at the price of a dangerous obscuring of their content, tend to make the school step back into a supposed neutrality, which enervates its educating potential and reflects negatively on the formation of the pupils.

Another Vatican document on education, Educating Together in Catholic Schools (Congregation for Catholic Education, 2007: para 26) explicitly states that formation must involve: 'the saving word of God in Sacred Scripture, in Tradition, above all liturgical and sacramental Tradition, enlightened by the Magisterium of the Church'. While no single formulation of a Catholic philosophy of education has been attempted since the Second Vatican Council, it is interesting that, as D'Souza (2016: 77), says that 'the documents of the Congregation of Catholic Education are formulated in a language more in keeping with the broader, more inclusive and holistic approach of Thomism'.

Central to this is the idea of virtue, which The Catechism of the Catholic Church (CCC n. 1994) defines as 'a habitual and firm disposition to do the good. It allows a person not only to perform good acts, but to give the best of himself. The Catechism (education in the faith) recognises that this capacity and desire to act well is a feature of a person's character; it is a quality in the person which perfects action. Another way to describe it is to say that a virtuous person is disposed to act well, and, in this sense, it is both a skill and an inclination to use that skill properly. It is through living the virtues that a person develops moral character because the virtuous person 'pursues the good and chooses it in concrete actions' because we 'not only perform good acts but give the best of ourselves' (CCC n. 1994: 1803). To achieve this, the Church focuses on the virtues, particularly the theological and cardinal virtues (CCC 1994: n. 1804-29) as it states: 'The theological virtues are the foundation of Christian moral activity; they animate it and give it its special character .... They inform and give life to all the moral virtues' (CCC n. 1994: 1813). Of all the virtues, charity is considered the most important since the Catechism (CCC n. 1994: 1827) says it is the source and goal of all the other virtues. Part Three of the Catechism, entitled 'Life in Christ', provides an overview of what the Church's moral teaching should contain, and it is also worth consulting the 2004 Compendium of the Social Doctrines of the Church, which points to the fact that living virtuously is not simply an individual choice but has a social dimension that contributes to the common good, principally through the virtues of justice and charity. A person's social context will determine, to some extent, the ideals for character that they will develop. In our Western pluralist culture, a variety of virtuous and non-virtuous options compete with each other for adoption, and what a human agent chooses determines the character constituted. Hauerwas (1981), among others, gives emphasis to the historical and social dimension of virtue, but few speak about this within educational contexts, particularly within schooling.

Catholic education is distinctive, but it constantly requires clarity about what this distinctiveness entails. As McLaughlin (1996: 139) says: 
The sort of clarity which is needed in relation to the distinctiveness of Catholic education needs therefore to go 'beyond the edu-babble'. More specifically, sustained attention to questions of the meaning and justification of central concepts and claims are needed, together with an attempt to delineate an overall substantial framework of Catholic educational thought.

He goes on to describe three general features that are distinctive of the curriculum and ethos of Catholic schooling:

Catholic education, and the Catholic school, is therefore distinctive in virtue of (1) its embodiment of a particular view about the meaning of human persons and of human life, (2) its aspirations to engage in a certain kind of holistic influence, and (3) its concern with the formation of its students in its own religious and moral tradition.

(McLaughlin, 1996: 145)

The Catholic school is concerned with the transmission of the rich moral tradition of the Catholic Church - a living tradition that forms the student's intellect and character by means of catechism, study of the scriptures, Catholic practices and teaching. McLaughlin's emphasis is on the rational basis for the Catholic faith, in which the student's autonomy and freedom of conscience are acknowledged within the boundaries of authentic Catholicism. The ethics taught should be lifeinvigorating and not unthinking, despite the fact that we learn the virtues through authoritative voices in a community that includes key figures such as parents and teachers.

Catholic education has, in living memory, largely followed a deontological approach, teaching with authority about the moral life through rules, principles and commandments. This approach was much criticised for ignoring context, the character of the person and the circumstances of the personal lives of people, and for being unrelated to real life. This reduced, for many, the moral life to a series of sins that required penance in the sacrament of reconciliation. This process of teaching rules, breaking these rules (sins), confessing and receiving forgiveness was also seen as inadequate for an authentic moral life. Virtue ethics was proposed as an alternative approach. However, this alternative approach should not be seen as doing away with the effects of sin on our nature, because, as Hauerwas (1983: 31) says: 'Our sin is not merely an error in overstating our capacities. Rather it is the active and wilful attempt to overreach our powers.' In most people sin begins little by little, almost in unnoticed steps that form new habits and affections which result in poor decision-making about good and evil. Students are neither vicious nor virtuous but are apt to become one or the other depending on upbringing, schooling, context, age and other criteria.

The Christian dimensions of character and virtues, based on Christian theology and philosophy, as well as a Christian anthropology, can be summarised in the following points. Christian anthropology understands our human nature not only 
in terms of what we are, but of what we may be. We have the potential to become what we are not yet, or are not fully. This divine transformation of the human being is an act of faith, and it is this faith that brings fragmented elements together in the formation of character and being. Christian faith changes the conception of virtue as a gift from God rather than solely the work of unaided human reason and effort. As the meaning and purpose of human life is union with God, consequently, a theory of morality in Christianity cannot be Christian if it does not ascribe the primary role to the Holy Spirit. Christ's normative humanity is also central because He is our true telos, which includes life after death. It is why the Christian needs to be regenerated by baptism to form Christ himself in our lives. The virtues of faith, hope and love begin in us at baptism and virtue is nothing other than the perfect love of God. If we do not know God we create idols pagan deities, rationalist ideas, new age rainbows; all kinds of myths that function as deities. Scripture, reason, tradition and experience aid the Christian's growth in character, and, to desire the good, we must orientate our soul towards the good. You could say that Christianity awakens a love for what is good in us. The Fathers of the Church recognised that to offer a genuine moral vision it must be tied directly to the Gospel as read and lived by the Church.

The virtues are transformed by faith. The Christian virtues direct us to the habitual pattern of the Christian life and these practices direct the Church towards the kind of community that embodies and forms the virtues. Christians move from the idea of wrongdoing and injustice to sin, with sin viewed as a rupture in the relationship between human beings and God, meaning that we are limited by sin. Virtues are therefore divided in terms of those acquired by repeated acts and those which are infused with sanctifying grace by God. This grace gives Christians a certain open-ended character, but the Christian ideal comprises everything that is excellent in the worldly ideal. Christianity honours nature as the creation of God's hands, but the acquired virtues are always subordinated to the divinely infused virtues, and phronesis is subordinate to grace. Christian virtues are not what humans achieve, but what God enables, and wisdom for the Christian is Jesus and requires participation in His Church for growth. To know God is to be transformed by the good, meaning that phronesis/wisdom is having the mind of Christ. The supernatural does not cancel or destroy the natural but presupposes it, adds to it, sublimates it, and elevates it. Human nature, being both graced and flawed, is always in need of God's salvation.

The telos for the Christian is union with Christ now and for eternity. Christians pursue this ideal because it is good, right and true. The Christian needs Christ and His grace and needs to desire to know, love and serve Him and enjoy a relationship with Him for eternity. The Christian sees virtue not as an end in itself, or even just as a means to heaven, but the way to become more like Christ or another Christ (ipse Christus, alter Christus) for others. That is the Christian mission in the world, the call from baptism. Virtues are not simply the good behaviours Christians develop in order to earn heaven and become Christlike, they help them grow in stature as children of God. 


\section{Suggested reading}

Adler, M. (1982) The Paideia Programme: An Educational Syllabus, New York: Macmillan.

A Neo-Aristotelian makes some interesting proposals on education and the curriculum.

Arthur, J., Kristjansson, K., Harrison, T., Sanderse, W., and Wright, D. (2017) Teaching Character and Virtue in Schools, London: Routledge.

A book that accompanies the framework and programmes of study produced by the Jubilee Centre for Character and Virtues. See Wright, D., Morris, I., and Bawden, M. (2014) Character Education: A Taught Course for 11-16 Year Olds, University of Birmingham: Jubilee Centre for Character and Virtues and www.jubilee centre.ac.uk

Arthur, J. (2003) Education with Character: The Moral Economy of Schooling, London: Routledge.

Chapters 9 and 10 survey the different teaching methods for character education. Lickona, T., Schaps, E., and Lewis, C. (2007) CEP's Eleven Principles of Effective Character Education, Washington: Character Education Partnership.

A classic expression of the principles that contribute to good character education.

Kristjansson, K. (2020) Flourishing as the Aim of Education: A Neo-Aristotelian View, London: Routledge.

Another Neo-Aristotelian presents the theoretical foundations of flourishing in education.

Pike, M. A. (2013) Mere Education: C.S. Lewis as Teacher for Our Time, Cambridge: Lutterworth Press.

A Christian approach to education for character.

Lickona, T. and Davidson, M. (2005) Smart and Good High Schools, New York: State University of New York.

This is a very detailed report on educational practices to promote character education. It includes an important section on spirituality.

\section{Questions}

How is one to inculcate virtues successfully?

What kind of activities (practices) are involved in teaching character ethics?

In preparing the goals of character formation, what should we consider?

What is virtue literacy?

What is the relationship between grace and effort in Christian character formation?

Thinking about the three roles of the Catholic school (to create an environment or culture that enables students to build and deepen their relationship with God, to foster an academic culture aimed at the pursuit of truth, and to actively promote growth in Christian virtues), what does each of these look like in practice?

What do you think it means for teaching to be a 'vocation?' How does this impact on the daily practice of the teacher? 
What is, or should be, distinctive about Catholic schools?

What do you understand by the term 'pedagogy?' What would a Christian pedagogy look like?

What pedagogical techniques can be used in the instruction of virtue?

What is virtue literacy and why might it be important? How can it be developed in schools?

What additional character education programmes or resources have you encountered? What are their strengths and weaknesses?

How might the Christian teacher play a role in encouraging good character in their students? What does it look like in practice?

How does the catholic school become 'a community of practice'? 


\section{Chapter 5}

\section{Integral human development and Christian character education}

We understand 'integral' as meaning to form or blend into a whole person, with various aspects of our character becoming consistent with each other. In a Christian context, this is part of our human flourishing as followers of Christ. The primary aim of Christian character formation is to assist the student to become a more faithful disciple: character virtues are needed to help us act in a certain way as a follower of Christ. Christian morality consists of living with guidance and inspiration from the Christian scriptures, tradition, human reason and experience. Christianity offers its followers guidance for living morally through its observances, beliefs and expectations. Christians have historically understood character formation as formation in discipleship, and this is a holistic process of shaping a person with a view to leading them to the actualisation of yearning 'for truth, for the good, for God and for love' (Akinwale, 2010). To be a follower of Christ is to have one's life formed by faith as revealed through His life. To grow in moral character is to become a disciple of Christ. As Bauerschmidt (2013: 223) notes:

This claim does not entail a naive view of imitating Christ. The concrete particulars of Jesus's life are not a set of actions to be mechanically imitated, but rather occasions for inquiring into the end toward which that action is directed.

We do not do this alone as we need to be in a community that supports and guides us, and this is the Church. Again, as Bauerschmidt (2013: 224) reminds us in an echo of Thomas: 'we do not read the gospel in isolation, but in the context of the Church and through the tradition of the saints'. It is the life and practices of the Christian community that help us understand the role of this community in cultivating the virtues. Hauerwas (1981: 116) understands that the development of character takes place in the context of a community shaped by a narrative. He argued that our daily conduct should be accompanied by an inward reformation of the heart. For Hauerwas, character is inseparable from justification and sanctification, and one cannot pursue a fully virtuous life without sanctification. We have seen from Thomas that we have natural dispositions to do what is right and refuse to do what is wrong, and that these are often impeded by sin. It is also the case that 
to function as moral agents we need more than good intentions. We need to implement those intentions, meaning that all of our human capabilities are relevant to the moral life. We need therefore a framework to help us think about Christian character formation in education; one that will provide principles for reflection, criteria for judgement and directions for action. However, Christian education is also character education that depends on the mode of living of the Christian community. What we are looking for is integral human development, and this begins and takes place in the family, the Church and in Christian schools.

Pope Benedict XVI's encyclical, Caritas in Veritate (2009), which has the subtitle On Integral Human Development in Charity and Truth, provides a theological vision underpinning the idea that the reality of existing as a human being is irreducibly relational. The encyclical argues that 'integral human development' focuses on 'charity in truth' and that 'everything has its origin in God's love, everything is shaped by it, everything is directed towards it' (Caritas, n1). Following Aquinas, Benedict argues that love is the form of all the virtues because love infuses all the other virtues. In other words, he argues that love is the key to 'integral human development' and that it 'demands self-fulfilment in a transcendent humanism which gives [to man] his greatest possible perfection: this is the highest goal of personal development' (Caritas, n18). Without love, the character virtues are deficient and lack ordering to their final end in God. Benedict recognises that the problem today is an 'excessive segmentation of knowledge' that results in an inability to 'see the integral good of man in its various dimensions' (Caritas, n31). He summarises:

Only if we are aware of our calling, as individuals and as a community, to be part of God's family as his sons and daughters, will we be able to generate a new vision and muster new energy in the service of a truly integral humanism. The greatest service to development, then, is a Christian humanism that enkindles charity and takes its lead from truth, accepting both as a lasting gift from God. Openness to God makes us open towards our brothers and sisters and towards an understanding of life as a joyful task to be accomplished in a spirit of solidarity.

(Caritas, n78)

Integral human development does not refer to individualistic self-development, but to the good of all persons and communities. Benedict uses the integrative capacities of both his metaphysical and theological approaches to promote virtue and wisdom that originate in love.

Benedict was influenced by the use of the term and conception of 'integral humanism' that Maritain (1968) conceived when arguing that integral education aimed at integral humanism. Maritain meant that the human being does not exist merely as a physical being, but rather is formed by the integral union of the spiritual and material dimensions. Development is linked to personal growth and seeks the maturation of the whole person. Integrated education is essentially a religious 
formation with the intent of liberating the person and enhancing their internal freedom. Human nature comprises many components: body, rational thought, appetites and desires, emotions, and the purpose of education is to integrate these. It must include the spiritual, moral, social and cultural. Pope Francis considers integral human development to be so important that he has created a Dicastery in the Vatican to promote it.

The first thing to notice about the Jubilee Centre's framework, considered in the previous chapter, is that its whole approach is secular in orientation. The differences between this framework and a potential Christian approach is that the Jubilee framework sees moral virtues within a social context, while a Christian approach sees significance within a context that is not exclusively social, but has a number of other dimensions besides. A Christian approach seeks to provide a theological understanding that illuminates and strengthens the familiar virtues but adds far more virtues. The virtues in a secular framework do not have as their object God, and so describe activities that are less perfectly virtuous and inferior to our final human end as Christians. Nevertheless, the framework has been used, with adaptations, in Anglican and Catholic schools.

If we place this secular virtue ethics approach within a Christian telos, then the moral life that it aims to develop becomes one that is in a relationship with Christ, which means that the way Jesus talks, acts, and feels becomes the model for the virtuous life. It is in union with Christ that we can share the virtues of Christ. As Crysdale (2002: 573) notes: 'If theology is faith seeking understanding then moral theology is faith seeking authentic living.' Because Christians understand moral theology as the study of the implications of faith in Christ or the way people live, the actions we perform, whether virtuous or not, affect our union with God and so all our moral actions have a religious significance. As explained earlier, the Church appeals to natural law as the basis of much of its teaching, and this law is concerned with the nature of the human person and what sorts of actions are consistent (or inconsistent) with human nature. This points to formation, which is needed, more than ever, to navigate through the moral diversity of this world. Navigation was the theme that C. S. Lewis (1942: 71ff) used in Mere Christianity to illustrate the notion of character in the moral life. He asks us to imagine a fleet of ships on the high seas and to consider why they do not collide with each other or get lost. He explains that the ships need three things. First, they need a destination if the journey is to succeed. Second, each ship needs a set of rules for their formation and to assign the specific roles in the fleet's mission. Third, the ships must have systems in place, such as sails or engines, electrical and navigational equipment, rudders, anchors, and so on. Lewis then applies this analogy to human beings and says what is true for a fleet of ships is true for us. First, our destination is our purpose in life, given to us by God. Second, our rules are sourced from Scripture, showing us how to make good choices and live good lives. Third, our systems are virtues for excellence, our character, for doing what is right. Nabers (2001: 35) extends the analogy by adding power for the sails or petrol for the engine and proposes that this power should be seen as the gift of grace from the Holy Spirit. 
Whether we become good people depends on a number of factors. First, the ethos of the family or institution that attempts to educate is key, since any teaching will only be efficacious if we have been nurtured in the right environment. Second, the teacher must be an exemplar of the virtues, able to communicate through eyes, voice and body those virtues that are necessary to build character. Education, however conceived, invariably affects a student's character for better or worse; it has moral effect. As Tigner (2000: 18) says:

The teacher-student relationship is a moral one between persons, and explicit recognition of this essential fact lies the beginning of any instructor's aspiring to help students in their quest to live flourishing lives. In recognizing their stature as persons, and in modelling worthy aims and aspirations, lie the foundations for a teacher's helping students raise up virtue from within themselves.

If we use a Christian lens to envision the Jubilee Centre's framework, we can construct a virtue-based framework for Christian education. All the virtues listed in the Jubilee Centre's framework can be seen, interpreted, and experienced through the lens of Christian beliefs and practices; particularly humility, justice, and compassion. While many virtues would overlap, Christians would give greater emphasis to particular virtues, such as human dignity and integrity. Moreover, Christians pursue distinct virtues that reflect their Christian calling, not generally to be seen in a list of ordinary virtues. These distinctly Christian virtues are in Table 5.1, combined with the secular virtues. As the list of character virtues related to each category may overlap, the table is meant to be illustrative, not exhaustive.

This list of virtues is seemingly endless, so it is important to understand the virtuous life in a way that is more holistic than a superficially scattered collection of virtues. There is a multitude of virtues we can possess that enable us to act well. A person's character is best seen in the whole, and too much focus on separate virtues, or on separate ends or motives, can obscure this totality. It should be emphasised that these secular virtues are lived differently by the Christian and the non-Christian. However, there seems to be a tension here since the more we say that people of any or no faith can act virtuously, the less it seems faith matters at all. The more we say that faith directly impacts what the virtuous life looks like, the more it seems it is accessible only to Christians. This tension was also experienced by non-Christians, such as the Roman Emperor Marcus Aurelius, to whom the following quotation is attributed, loosely based on his Meditations:

Live a good life. If there are gods and they are just, then they will not care how devout you have been, but will welcome you based on the virtues you have lived by. If there are gods, but unjust, then you should not want to worship them. If there are no gods, then you will be gone, but will have lived a noble life that will live on in the memories of your loved ones. 
Table 5.I Christian and secular virtues

\begin{tabular}{|c|c|c|c|c|}
\hline $\begin{array}{l}\text { Intellectual } \\
\text { virtues }\end{array}$ & Moral virtues & Civic virtues & Performance virtues & Christian virtues \\
\hline Autonomy & Compassion & Citizenship & Confidence & Faith \\
\hline $\begin{array}{l}\text { Critical } \\
\text { thinking }\end{array}$ & Courage & Civility & Determination & Hope \\
\hline Curiosity & Gratitude & $\begin{array}{l}\text { Community } \\
\text { awareness }\end{array}$ & Motivation & Love \\
\hline Judgement & Honesty & $\begin{array}{l}\text { Neighbourli- } \\
\text { ness }\end{array}$ & Perseverance & Piety \\
\hline Reasoning & Humility & Service & Resilience & Fidelity \\
\hline Reflection & Integrity & Volunteering & Teamwork & Fellowship \\
\hline $\begin{array}{l}\text { Resourceful- } \\
\text { ness }\end{array}$ & Justice & Friendliness & Grit & Holiness \\
\hline Vision & Respect & Charitableness & $\begin{array}{l}\text { Bounce-back- } \\
\text { ability }\end{array}$ & Reverence \\
\hline Foresight & Care & Co-operation & Industriousness & Mercy \\
\hline Openness & Kindness & Courtesy & Dedication & Grace \\
\hline Optimism & Generosity & Tolerance & Ambition & Joy \\
\hline Pride & Fairness & Trust & Leadership & Patience \\
\hline Forbearance & Selflessness & Helpfulness & $\begin{array}{l}\text { Communicative- } \\
\text { ness }\end{array}$ & Spirituality \\
\hline Imagination & Loyalty & Patriotism & Enthusiasm & Godliness \\
\hline Awareness & Forgiveness & Affability & Diligence & Wonder \\
\hline Creativity & Honour & Dependability & Productiveness & Detachment \\
\hline \multirow[t]{9}{*}{ Wonder } & & & Persistence & Abstinence \\
\hline & & & & Counsel \\
\hline & & & & Prayerfulness \\
\hline & & & & Modesty \\
\hline & & & & Sincerity \\
\hline & & & & Docility \\
\hline & & & & Magnanimity \\
\hline & & & & Peacefulness \\
\hline & & & & Clemency \\
\hline
\end{tabular}

Marcus Aurelius gives reasons why the virtues are key to a good life whether or not you believe in God.

The Christian virtues listed in Table 5.1 are usually claimed as such because Christians recognise and place stress upon them. There is something peculiarly 
Christian about these virtues as they have a quality not obviously possessed by the other categories of virtues, but how far we can say there is a special list of Christian virtues is often debated. Humility, for example, could be seen as a virtue that is both secular and Christian. Nevertheless, we can say that there is a certain quality that a virtue may possess when held by a Christian, and this is always related to love. Generosity or kindness is a product of love and involves giving to others without counting the cost. Forgiveness, in Christian thinking, helps the Christian turn from the things they have done wrong in order to love God and their neighbour with their whole heart. Christian life is different from secular life, meaning that the Christian virtues are distinct because they are distinct from the secular telos. The Christian sees God as the source and goal of all virtues.

Since the theological virtues of faith, hope and love are the foundation of the Christian life, they become the ground for the all the other virtues listed in this framework. By faith, we believe in God and in what God has revealed to us so that we constantly seek to know His will. Faith thereby perfects the intellectual virtues so that they contribute positively to the moral ones. In hope, we desire the Kingdom of heaven and eternal life as our happiness, and put our hope in Christ. In love, we love God above all things for His own sake and our neighbour as ourselves (John 15: 9.12). The theological virtues are entirely gifts of God because they cannot be obtained by human effort. Our character, then, is what we are when no one sees us but God. This is why a Catholic school needs to focus on prayer, the sacraments and reading the gospel to help its students receive God's grace. The theological virtues collectively inform and animate the natural virtues, at the core of which are the cardinal virtues (prudence, justice, fortitude and temperance). Faith, hope and love transform the cardinal virtues in both meaning and practice.

The Jubilee Centre's framework virtues can be understood as constituting the four cardinal virtues. One could say that each of these virtues listed in the framework is annexed to one of the cardinal virtues. These virtues are also cultivated together since you cannot develop one without nurturing the others - they are interdependent and grow together. Christianity similarly found the pagan cardinal virtues a useful way to present part of the moral life. As Anderson (2020: 20) notes: 'while the four cardinal virtues make the possessor good and his work good, they can only render that person and work good for a terrestrial aim'. Prudence is the virtue that dispenses practical reason to discern our true good in every circumstance and to choose the right means of achieving it. As Proverbs says: 'The prudent man looks where he is going' (Proverbs: 14:15). It is the advisor for moral discernment and action, the ability to know what to do, how to act and what to say in any situation. Justice is essentially about a relationship with others and is the desire to do what is right. Fortitude is consistency in the pursuit of the good and strengthens our resolve to resist temptation, therefore helping us to overcome obstacles to a Christian moral life. It gives us strength to carry out the good we desire. Temperance moderates the attractiveness of pleasure and provides a balance in the use of created goods. It helps us to regulate our desires and prevent overindulgence. With these cardinal and theological virtues in mind, let us now 
examine the four virtue categories used in the Jubilee Centre framework through a Christian lens. Although Thomas mentions more than 50 moral virtues, these are not intended to be exhaustive, but they are all part of the cardinal virtues from which all the moral virtues flow.

Such an examination returns us to the question of how distinctive in form and meaning Christian virtues are. To answer this, we can take two virtues, generosity (from the moral category) and charitableness (from the civic category) in Table 5.1. The civic virtues are essentially a sub-set of the moral virtues. In the Greco-Roman world, generosity and charity were called almsgiving, benevolence, hospitality, sharing and liberality, and the Jews might have referred to them as justice. In what sense was the nature, content and operation of these virtues different for the Christian believer? In the classical world, they were considered appropriate and necessary to the character of the good person. However, the operation of these virtues was not motivated by compassion for an individual in need, but rather by the need to develop one's own public character. Aristotle had taught that there is no nobility in giving to others per se, for the person of character must give rightly to the right people for the right reasons. While the person of character will be generous, the practice of his generosity is linked to the pursuit of praise and recognition. Generosity was to be discriminating and selective, and was only afforded to those considered worthy (see Garrison, 1993: 41ff). Charity and generosity were to be given only to those who were virtuous, and the poor were not considered virtuous. Plato, in his Republic, demonstrates contempt for and hostility towards the poor, describing beggars as the symptom of crime. As poverty was considered a disgraceful state, compassion was not to be shown to the poor, and generosity in practice in the Greco-Roman world was normally reserved for social peers, family, relatives, friends and equals. In giving to others, the giver's reputation was enhanced, and recipients became beholden to him. As Herman (2006: 261) notes:

During most phases of European history pro-social behaviour has been equated with virtue and anti-social behaviour with vice. In the Homeric world this equation is almost reversed: the virtues (aretai) on which the heroes pride themselves tend to be self-regarding in the extreme. Devoting all their powers to individualistic pursuits, these heroes exalt their egotistic senses of honour above everything, even country and life.

Aristotle's magnanimous (or proud) man is directly opposed to Christian humility, and there is a general worldliness implicit in Aristotle's virtues which Christianity rejected. Aristotle believed that the person who possessed 'high-mindedness' must also possess all the virtues and hence was justified in looking down on others. The Christian meaning and practice of the virtues of generosity and charity were radically different, as can be seen in Luke 14: 12-14. The Christian view requires concern for all people and an active love for all humankind (philanthropy). A sense of universal brotherhood was to be inculcated and Christian generosity and charity were not only a duty, but, more importantly, an opportunity to respect and honour the image 
of God that resides in every human being irrespective of their background, status or beliefs. St. Paul taught that these virtues were to be practised based on the need and not the merit of others (Romans 12: 3-16). Some Christians saw the virtue of charity as a way of atoning for their sins, and this was especially seen in the redemptive power of prayer, with the poor praying for those who gave in charity. Generosity was considered an expression of fellowship within the Christian community, but care and hospitality were also to be extended to all those outside of it. Almsgiving, in particular, was consistently promoted by the Christian community in sermons and by the example of saints, distinguishing Christians' practice of this virtue from that of non-Christians in the Greco-Roman world. Consequently, we can say that Christian beliefs transformed these virtues to make them distinctly Christian. This emphasis on generosity, charity, almsgiving and hospitality in the fourth century gave rise to the development of hospitals and other institutions to attend to the sick, the hungry, the dying, the poor, the elderly and the outcasts. The institutions and organisations that were established, in a hugely unequal society, were rooted in the distinctive Christian virtues of charity and hospitality. For example, the Bible has many references to aiding the widow (i.e., Psalm 146: 9 and 1 Timothy 5: 16). Widows were particularly vulnerable in Greco-Roman society since they were at the bottom of the social ladder, and many were destitute. The Church supported them and restored their personal dignity and status. More broadly, people who were hungry knew where to go - the Christian community. Through the practice of Christian virtue, the Christian community made them an equal of all its other members. As these examples show, we can also say that the virtues of generosity and charity led to the manifestation of the virtues of gratitude, humility and thankfulness, demonstrating the interconnected nature of the virtues.

The virtues and personal character of Christians helped them to stand out, and many non-Christians saw them as a benefit to society. Emperor Julian the Apostate observed that the Christians looked after strangers and even cared for the graves of the dead. The historian Eusebius also commented that Christians who took charge of the sick sometimes died doing so by catching the disease from strangers as they ministered to them 'in Christ' (Ehrman, 2018: 138ff). Infusion of biblical content into commonly accepted notions of virtue set Christians apart from their pagan neighbours. They focused on love of neighbour and saw the person as one, and only one, among others. They understood virtues as moving human beings, both individually and communally, towards the human good. Christians acquired and developed these virtues within a community of faith, and virtues must therefore be informed by Christian tradition, experience and scriptures. For the Greco-Roman world, wisdom was the supreme virtue; wisdom in a practical sense, meaning that a wise person could know what to do and how and when to do it. The people of this world knew that money, sex, pleasure and status did not necessarily make you happy, and that those who experience poverty, loss of loved ones and ill health could retain an inner happiness. What they did not know was why. This may explain why their philosophers encouraged the search for theoretical wisdom that could ultimately understand the 'divine' - and hence the 'why' of things. 
Christians answered this 'why' with the Incarnation of Christ - God taking human flesh, living in time and space, redeeming the world through His sacrifice on the cross. While Christians recognised that some people were genuinely virtuous in the Greco-Roman world, they also believed that they had not been granted full knowledge of Christ, and therefore their virtues might not contribute towards salvation. Augustine went so far to say that their virtues were merely apparent and not real. To the Greek, the idea of neighbour simply meant 'my fellow Greek' and this was limited and excluded many while the Christian idea of neighbour was unlimited and all embracing.

An analogue of the divide between Greco-Roman and early Christianity can be seen in the division between the secular and the Christian today. There are numerous studies showing continuing connection between religion and generosity. Putnam and Campbell (2002) demonstrated in their large US study that Christians gave more, and more often, to charitable causes and volunteered their time more than non-religious Americans. The Christian Church has retained a strong pedagogical influence over giving and volunteering, which have always been encouraged as habits in churches. The Roman Catholic Church remains the largest non-governmental provider of healthcare in the world, managing 26 per cent of the world's healthcare facilities, largely located in the Majority World (see Agnew, 2010). Christian beliefs continue to be an important motivator for charity, even supporting causes which are secular in nature. Ultimately, Thomas held that charity was the most excellent of virtues, enabling our friendship with God and unfolding into love for others. It is a theological virtue and completely unique to a Christian understanding. It requires a distinct way of life that espouses certain commitments, combined with a disposition to express the Christian faith by acting upon it. Nevertheless, the major religions in the world, Lawler and Salzman (2013: 473) note:

agree broadly on core ethical values, norms, and behaviors, as evidenced by their various, and uncommonly similar, versions of the Golden Rule. For Christians it is: 'Whatever you wish that men would do to you, do so to them; for this is the law and the prophets' (Mt 7:12). For Jews: 'What is hateful to you do not do to your fellowman. This is the entire law; all the rest is commentary' (Talmud, Shabbat, 3id). For Muslims: 'No one of you is a believer until he desires for his brother that which he desires for himself (Sunnah).

Yet although there are some virtuous exhortations that Christianity holds in common with other religions, the practice of them is often different.

\section{Towards Christian intellectual virtues}

Character formation - both intellectual and moral formation - is integral to the education Christianity requires of its followers. In directing us to a concern for how we should think, the intellectual virtues aim at cognate goods of truth, knowledge and understanding, develop our minds and help us understand the world around us. 
While the character or moral virtues are always accompanied by specific motivations to act towards the goods in question, the intellectual virtues make us capable of performing certain acts without providing any motivation to do so. One could say that the intellectual virtues make us good at doing something like mathematics or history, but they do not necessarily make us good human beings. A teacher or student with the intellectual virtues can be dishonest, greedy or arrogant, and a disgraceful person. We can possess the intellectual virtues without being morally good because the intellectual virtues do not have the appropriate love or desire built into them. For instance, to know what self-control is, is not sufficient to exercise it. Thomas argued that some people have the intellectual virtues but do not appreciate them as a good fulfilling of their human capacities. One needs knowledge in order for them to grow into real wisdom. Whereas the moral virtues have the appropriate amount of love built into them, the intellectual virtues have the good, but not necessarily the amount of love for something to be truly fulfilling. Thus, in order to have the intellectual virtues in a Christian sense, we must love them and pursue them insofar as we are able. We must hold the truth to be worth seeking, and this is why Thomas includes the virtue of studiousness as directed towards the discovery of truth. If a student is lazy, then it becomes a clear obstacle to pursuing the truth and to developing their skills and talents. A good student will freely pursue the truth and develop their own capacities.

Nevertheless, there are periods of time in our lives in which we experience a degree of desolation in the spiritual domain; sometimes called 'the dark night of the soul' and felt when we do not feel the presence of God in our lives. C. S. Lewis (2001: 39-40), in the Screwtape Letters, describes such a point in the Christian's life through the eyes of the devil:

sooner or later [God] withdraws, if not in fact, at least from a believer's conscious experience, all supports and incentives. He leaves the creature to stand up on its own legs - to carry out from the will alone duties which have lost all relish. He cannot 'tempt' to virtue as we do to vice. He wants them to learn to walk and must therefore take away his hand. Our course is never more in danger than when a human, no longer desiring, but still intending, to do [God's] will, looks round upon a universe from which every trace of him seems to have vanished, and asks why he has been forsaken and still obeys.

The pursuit of knowledge, through subjects in the curriculum, requires good moral habits. As Zagzebski (1996: 159) writes:

Envy, pride, and the urge to reinforce prejudices can easily inhibit the acquisition of intellectual virtues. A person without sufficient self-respect and an inordinate need to be liked by others may tend to intellectual conformity. An egoistic person will want to get his way, and this includes wanting to be right. He will therefore resist any demonstration of a mistake in his beliefs. If his belief is about a topic of contemporary debate, his egoism may lead him to 
read only those articles that support how own position and to discuss politics only with like-minded individuals.

The intellectual virtues require the moral virtues in any Christian understanding. If we reason about something, we need the emotional dimension to help us make our choices real. Where the school has, essentially, a role in developing intellect and knowledge, it also has an impact on the will and thereby has a moral task to perform: it must help build the intellectual foundations of the moral life.

There are some who would argue that we should simply promote the intellectual virtues such as autonomy and reasoning in school. There are others who think that what is important in our schools is the performance virtues of resilience and motivation, while others still think that citizenship and the purely civic virtues should be given priority. Few choose moral virtues as such, and yet we require all four categories of virtue in the formation of moral character since all are essential parts of the goals of education, in the broad sense of the word. A school cannot secure such formation in a full and complete manner, yet it must contribute positively to such a goal. In their relation to the intellectual virtues, schools should remind us that we have to know reality before we can do what is good.

\section{Towards Christian moral virtues}

People are especially good at disagreeing over moral virtues, even when they agree that moral character is formed by our actions. When we speak of character virtues, we are thinking about what we should do and feel, and therefore we are thinking about the moral virtues. The moral virtues have to do with acting and choosing in the light of knowledge. You could say that a moral virtue is a will-virtue that needs to listen to reason. The moral virtues affect our relations with our neighbour and ourselves. While intellectual virtues concern the mind or reason, moral virtues concern our appetites or desires. Intellectual virtues help us to think well, while moral virtues help us to desire well. We cannot have the moral virtues if we do not have wisdom, but we are not simply wise or unwise: we are wise to some degree. Prudence is important here because it directs the moral virtues and is superior to the moral virtues - it is, as Thomas says: 'right reasoning about what is to be done'. It is we, as free individuals, who must determine what is according to reason. Wisdom is not simply a matter of excellent thinking or prudent judgement. The wise person is certainly one who judges well, but the capacity to solve intricate ethical dilemmas is only one aspect of wisdom, and even that capacity cannot be reduced to intelligence alone.

Thomas makes clear that the moral life constitutes a personal friendship with God; an intimate relationship with God through Christ. This can only be achieved through prayer and spiritual renewal that allows the Holy Spirit to work within us. He discusses the distinction between those who have an intellectual knowledge of the virtues and those that have a connatural knowledge of them. This connatural knowledge is also a kind of instinctive moral knowledge - it is gained as a result of the experience of the virtue and can also 
be gifted by the Holy Spirit. Cessario (2001) calls it 'interior illumination', which elevates the ordinarily acquired moral virtues. There are therefore two ways of obtaining moral judgement: one by way of reason and the other by way of connaturality.

\section{Towards Christian civic virtues}

In terms of civic virtues, the Jesuits are an excellent example of how the virtue was understood and practised. The Jesuits aimed to provide a well-rounded education in order to 'save souls' or, to put it in more civic-virtue terms, to 'help others' and to advance the common good. But they also provided students with skills and knowledge deemed necessary constituents of civic life. The aim of such an education was to produce virtuous, active citizens, and the learning of moral wisdom was for social or civic purposes. The idea of virtue here 'consists of action' or participation in the public realm for advancing the common good. They believed, as did Aristotle, that we must educate citizens to be virtuous since without virtues social life in the city is impossible. Civic virtues are thus essentially part of the moral virtues and concern virtuous behaviour in relationship to a citizen's involvement in community/society. Aristotle claimed that the good citizen could be identified with the good person because the good person possessed practical wisdom for being a good citizen and leader.

Seeing civic virtues in Christian terms helps us to deepen our ties with the wider community, since without civic virtues we do not look beyond the family or Church and may be less likely to volunteer our time and money, to participate in groups that benefit society, or develop a sense of social responsibility for our neighbours. The Christian approach to civic virtues emphasises the goal or intention to benefit the whole of the wider community due to its focus on service. Christians cannot remain closed to the wider community or be protected from the world. Most modern institutions are marked by practices of exclusion and care for their own members, but the Church cannot do this, since its mission is to serve others in the world - the good of the community takes precedence over the good of the individual within the community. Ultimately, as Augustine said, the goal is to seek to lead the citizens of earth towards citizenship in heaven.

\section{Towards Christian performance virtues}

Performance virtues are essentially instrumental or motivational 'virtues' that are concerned with getting things done, but they, too, have an ethical dimension. They, like the intellectual virtues, do not necessarily make a person a good human being, since they may lack any particular disposition towards the good. Indeed, these 'virtues' are really a set of skills or acquired competencies that are essential to exercising the intellectual, moral and civic virtues. While moral virtues are about doing the right thing, performance virtues are about doing things right. To be valuable, they require a purpose and are always intimately linked to the other 
virtues. In teaching these skill-related virtues, we need to ask why we are teaching them, for what purpose, and whether or not they will assist the other virtues to advance the good. These kinds of skill virtues can be used for good or ill, and the Christian does not seek to acquire them unless they are employed to advance Christian ends. David Brooks (2015) refers to these skill virtues as résumé virtues, when he writes in the New York Times:

It occurred to me that there were two sets of virtues, the résumé virtues and the eulogy virtues. The résumé virtues are the skills you bring to the marketplace. The eulogy virtues are the ones that are talked about at your funeral - whether you were kind, brave, honest or faithful. Were you capable of deep love .... We all know that the eulogy virtues are more important than the résumé ones. But our culture and our educational systems spend more time teaching the skills and strategies you need for career success than the qualities you need to radiate that sort of inner light. Many of us are clearer on how to build an external career than on how to build inner character.

Essentially, Brooks is telling us that we master the skills necessary for success by wrongly acquiring and emphasising the performance virtues for their own sake.

Brooks (2015a: x) developed these two different types of résumé and eulogy virtues in his book, The Road to Character, in which he adapted the ideas of Rabbi Joseph Soloveitchick's Lonely Man of Faith, published in 1965. This divided human nature into two opposing sides as represented by a notional Adam I and Adam II from the Book of Genesis. Adam I is the career-orientated, ambitious side of our nature which seeks wealth, power and status. Adam II, by contrast, seeks to embody certain moral qualities, to nurture inner character, and to develop a sense of right and wrong to not only to do good but to be good. Adam II wishes to love others intimately, to sacrifice self in the service of others, and to live in obedience to some transcendent truth. As Brooks (2015a: x) summarises:

While Adam I wants to conquer the world, Adam II wants to obey a calling to serve the world. While Adam I is creative and savours his own accomplishments, Adam II sometimes renounces worldly success and status for the sake of some sacred purpose. While Adam I asks how things work, Adam II asks why they exist, and what ultimately we are here for. While Adam I wants to venture forth, Adam II wants to return to his roots and savour the warmth of a family meal. While Adam I's motto is 'Success', Adam II experiences life as a moral drama. His motto is 'Charity, love, and redemption'. Adam I is solely interested in those performance virtues that will advance him in the world.

What society needs is many more Adam IIs, and Brooks (2015a: 74ff) is clearly indicating, later in his book, that this is possible through Christian character. He presents an example of Adam II in the life of Dorothy Day, a radical social activist and Catholic convert, who embedded the virtues of Adam II in her life, and who 
saw the performance virtues solely as a means to promote the moral and civic virtues. Soloveitchick's original Adam II is guided by the quest for redemption and longs for an intimate relationship with God and with his fellow man in order to overcome his sense of incompleteness and inadequacy. For the Christian you could say that this manifests itself in love and that the actions of love are the performative consequences of faith. As Tigner (2000: 13) says:

Before good character can be consciously cultivated it must become an object of attention. Students must be encouraged to think about who they are as well as what they have in the way of wealth, reputation and honors (to use Socrates' phrase), to be concerned with the quality of their lives as well as the quality of their résumé.

\section{Towards Christian good sense}

Herbert McCabe OP (cited in Davies and Kucharski, 2016: 315) defines good sense as the disposition to do our practical reasoning well, involving a sensitive awareness of a multitude of factors that may be relevant to our decision-making. Good sense helps our intellect to discover what is good and assists us to select the right means in achieving good by giving direction to the virtues we acquire. Without education, we cannot achieve good sense or live well. Good sense (alternatively understood as practical wisdom, prudence, phronesis or simply wisdom) bridges the gap between mental judgement and affective desire. It is right reason about things to be done those who possess wisdom not only know the good but seek to bring it about. Thomas believed that good sense has three primary acts: counsel, judgement and command. In the act of counsel, we assess the options before us. In the act of judgement, we determine which of the options is best. In the act of command, we command ourselves to do it. Good sense is therefore not only an intellectual virtue, it is a moral virtue as well, and the decisions we make in the moral life utilise a combination of intellectual and moral virtues. Good sense is ultimately concerned with knowing how to act. Many of us successfully achieve both counsel and judgement but are often unable to bring ourselves to apply them. We judge what is to be done but cannot direct or move ourselves to act, and we therefore fail to become wise. Experience is needed, but we know that the young are not experienced in making good decisions because good sense is the hardest kind of knowledge to learn, and it develops over an extended time frame. This is why Aristotle wrote that a young person couldn't have the moral virtue of prudence, since he does not yet have life experience (Ethics, VI viii 5-6).

Good sense is the highest moral virtue that integrates the other virtues - it presupposes them. Thomas saw that it demands dispositions of docility (learning from others and for yourself). It develops not in linear or simple ways but in multiple ways of knowing that combine rational thought with imagination and dispositions towards knowledge. Good sense essentially provides us with a discerning and deliberating 
rationality that determines what course of action is reasonable. However, this is not seen within a philosophical sense. Rather, this Christian wisdom/phronesis/practical wisdom has a vision of the good that is fixed upon Christ. A result of this union with Christ is that we are able to share in the moral virtues of Christ.

In Christian thinking, good sense is guided by the love of Christian wisdom, which is knowledge of God. We have seen how good sense or practical wisdom was called phronesis by Aristotle and prudentia (prudence) by Thomas. Whilst this good sense or practical wisdom is concerned with acting rightly in concrete situations and is an everyday sort of wisdom, there is a higher form of wisdom, which Aristotle called sophia and Thomas called sapientia. For the Christian, this notion of sapientia is understood in relation to God and is associated with the grace freely given to us by the Holy Spirit. This wisdom of God is obtained through grace by our faithful search for God and is revealed in the Gospels. In the New Testament, both Matthew and Luke present Jesus as the teacher of wisdom and St. Paul speaks of Jesus as 'the power of God and the wisdom of God' (1 Corinthians 1: 24) to a culture that was dominated by the language of wisdom, virtues and happiness. Responding to the voice of God in Scripture is a process of getting to know God and is one way in which we acquire God's wisdom. This wisdom helps us make wise choices in life and is a kind of knowledge with a teleology: the formation of virtue in God's people. This Christian wisdom contrasts with what may be called a philosophical wisdom that views everything from reason. Instead, it is an analytic and intellectual mode of knowing, an approach to wisdom that is cognitive-heavy, and which emphasises knowledge, understanding, expertise, rules and skills. One could say it is a kind of instrumental intelligence, which may or may not be for the advancement of the good. While this philosophical wisdom is generally necessary for reading and understanding the Gospels, there is a wisdom that goes beyond knowledge and expertise. In this form, you do not need to acquire more knowledge to be wise, but rather you need to be open and aware of God's wisdom in your very being. This mode of wisdom is less cognitive in orientation and certainly more holistic, mystical and spiritual. It may be called theological wisdom based on rational research and revealed truths that cannot be proven and is perhaps best expressed by Simone Weil (2009) as 'waiting on God'.

This understanding of Christian wisdom has been emphasised by Christianity since its early centuries, when it stressed that there exists a profound wisdom in a simple Christian faith that recognises the goodness of God to be the cause of all things. Christian wisdom is shared with us through faith, and it offers an intelligent perspective that is higher than philosophical wisdom. It is a gift of the Holy Spirit and comes to us through God's grace. It is active, in that it leads us towards change and conversion so that we learn to love anew every day. It helps us to see with the eyes of God and to persevere in charity. It means that those Christians without formal education can have, as Thomas said, 'the ability of seeing through things' to see reality clearly and thereby make decisions that are good for others and ourselves. All human beings, according to Thomas, have a dispositional tendency to try to avoid evil and have a 'natural habit' of knowing this principle (see 
Budziszewski, 2017: 155). Nevertheless, there are intelligent people who are not wise, and there are uneducated people with a God-given affinity for goodness and wise decision-making. Determining what we see is who we are, and what we choose in our visions of the world (and so our character) is intimately connected with this vision. This kind of wisdom does not rely on intellectual reasoning, but on a receptiveness to God's wisdom in ordinary practical life, experienced in the Christian community. It is more a wisdom of being that is instinctively aware of God's will to do the good. The mystical dimension of wisdom, as described by Augustine in his Confessions when he tells the story of how he and his mother Monica briefly touched wisdom, is also within reach of all who search for God's wisdom through following Christ. Moreover, we can say that Jesus is the source and cause of wisdom and that he shares this wisdom with us so that we may grow in it. St. Paul, while seeing value in the best of Greek wisdom (Phil 4: 8), 'affirmed and defended the superiority of the wisdom of God, communicated through faith, over all human knowledge and wisdom, particularly by resisting the autonomy and anthropocentricism they inculcate' (Pinckaers, 1995: 296). A wisdom of the mind and heart is what we should aim at, along with acknowledging that: 'We live in a world whose mystery transcends us and ... morality is the exploration of that mystery in so far as it concerns each individual' (Murdoch, 1966: 208). Our minds need to be transformed if we are to be wise Christians, and, without the guidance of wisdom, all the virtues go awry. In sum, Christian practical wisdom gives us the ability to know what ends or goals are worth pursuing and what means are most likely to achieve them. As Ashley usefully says:

Christian moral wisdom is to be found not merely in particular good acts, but in the character of a person who has the constant capacity to live as a Christian day in and day out in all kinds of circumstances. As Jesus says in the Sermon on the Mount, 'A good tree cannot bear bad fruit, nor can a rotten tree bear good fruit'.

(Matthew 7: 18)

Practical wisdom therefore requires that we deliberate, judge and act according to our conscience and prudence. Christian wisdom is what we request of God (James 1:5) and is given as a gift to be treasured more than gold (Proverbs 16: 16).

In an educational context, young children recognise that some things are desirable or to be pursued, and in doing so children perceive that other things are to be avoided. There seems to be a teleological movement here as children grow in maturity from being a child to being a practically wise human being. Practical wisdom here is the capacity to resolve, through deliberation and reflection, the question of what we ought to do, and so how we should live requires practical wisdom, and this in turn enables us to become more human. Thomas would have said that to be morally good is to fulfil one's nature and that the goal of the moral life is to become what we are. In this sense, the Christian virtues and practical wisdom describe what we are, both naturally and supernaturally. 


\section{Christian virtue education in practice}

The rest of this chapter will focus on the different practical education programmes that are designed to promote Christian virtues. While some of these programmes do not explicitly mention either Aristotle or Thomas, they are certainly influenced by their thinking. All the contexts for these programmes are Catholic schools which have been forming students in dispositional virtues and attitudes for centuries without ever having to quantify results. Consequently, all of these programmes recognise and reject the current trend in education to quantify everything. They also recognise that in modern schools teaching reasoning skills, not the virtues, is often considered the means to a moral education. Modern educators think that moral education is about children discovering and clarifying for themselves their own values and personal moral stance in the world - to invent their own personal moralities. This approach is justified by their prior commitments to certain psychological theories that raise personal autonomy and self-realisation above any external authority. Their reasoning is that the teacher must not introduce values into the classroom, but rather work to 'draw out' from children their own moral beliefs and, through a process of clarification, help them better express their own values. However, even in this clarification process the teacher ultimately decides what is to be developed and what is to be drawn out - it is hardly a neutral approach. In addition, there is a widespread belief that there is a set of critical-thinking skills that can be taught, regardless of context or subject area. Thomas constantly speaks of the intellectual virtues and of our human capacity to reason, which I take to mean our engagement in critical thinking and which is why critical thinking is listed as one of our intellectual virtues. However, as Willingham (2007) has argued, it is not at all easy to teach critical thinking, particularly in a time of political correctness. Anything that is not politically correct is automatically designated controversial, which is really a way of silencing debate, particularly if it involves ideas perceived to be 'non-progressive'. It also replaces reason with emotion and subordinates truth to feeling: it effectively prevents critical thinking. Critical thinking requires the understanding of context, and it needs knowledge or factual content with which to engage in order to assist us make better judgements, improve our reasoning and think more logically. Thomas encourages us to be open to new evidence, to weigh-up this evidence, to examine the facts critically, to see both sides of the argument, but, above all, to use our reasoning to come to the right conclusion. He would have agreed with Willingham (2007) that: 'Thought processes are intertwined with what is being thought about' and that a liberal education is the best way to inculcate a critical engagement with knowledge and experience. 'There is no other foundation for the educational task,' explains Maritain (1962: 48), 'than the eternal saying: It is truth which sets man free.' The programmes that follow incorporate the aims of both Willingham and Maritain.

It is also helpful before introducing these programmes to think of Ashley's (1996: 112ff) series of steps by which we can integrate moral action into how we manage our lives well. The key to these steps is the availability of time to acquire experience, and so, as students in schools lack experience, they need to have a guided and 
graduated build-up of their character virtues. The eight steps that help us evaluate the concrete moral problems we face are: (1) use of memory - to learn from past experiences and actions; (2) use of intelligence - to understand issues; (3) gathering information - to learn from others who help us judge; (4) use of ingenuity - to look at all possible means to achieve our goals; (5) use of reasoning - to think about what should be done; (6) use of foresight - to carry out our decisions by the use of foresight; (7) use of circumspection - to assess the context in which we are acting; (8) use of caution - to identify the obstacles which may frustrate our completion of a task. Applying these steps to education is possible, but challenging. Each of the following virtue education programmes follows many of Ashley's steps.

The British Jesuits have developed a profile system in their schools that attempts to answer the question 'What kind of people do we want to help you to be?' It is a virtue approach for forming young people between the ages of 3 and 18 and is based on the virtues found in the Christian tradition as practised by the Jesuits. It aims to glorify God and serve the common good, and it is designed to be open to all, whether Christian or not. It has three distinct aims:

(a) to produce a statement of the qualities which pupils in Jesuit schools should seek to develop, (b) to produce a profile that describes the whole process of a Jesuit education at each stage, (c) to create a usable and identifiable image which complements the formal statement: this is in the form of a WORD TREE made up of eight pairs of VIRTUES that sum up what pupils at Jesuits schools are growing to become.

The image and the statement are designed to provide a resource to stimulate discussion in class, assemblies, retreats and liturgy, in meetings of governors, with school leaders, teachers, support staff and parents, and which can be used to explain to prospective parents the aims of Jesuit education (Porter, 2017). It represents one of the most sophisticated ways of building character and virtues from a Christian perspective, and parts of it have been adopted by many Catholic schools in England. In summary, it states that:

Pupils in a Jesuit school are growing to be ... Grateful for their own gifts, for the gift of other people, and for the blessings of each day; and generous with their gifts, becoming men and women for others. Attentive to their experience and to their vocation; and discerning about the choices they make and the effects of those choices. Compassionate towards others, near and far, especially the less fortunate; and loving by their just actions and forgiving words. Faith-filled in their beliefs and hopeful for the future. Eloquent and truthful in what they say of themselves, the relations between people, and the world. Learned, finding God in all things; and wise in the ways they use their learning for the common good. Curious about everything; and active in their engagement with the world, changing what they can for the better. Intentional in the way they live and use the resources of the earth, guided by conscience; and prophetic in the example they set to others.

(Porter, 2017) 
The profile offers a series of virtues, linked in pairs, that are intended to provide pupils with useful tools for discernment:

Grateful and Generous

Attentive and Discerning

Compassionate and Loving

Faith-filled and Hopeful

Eloquent and Truthful

Learned and Wise

Curious and Active

Intentional and Prophetic.

To understand the educational philosophy behind this approach to cultivating Christian character virtues, it is important to comprehend that Jesuit education seeks to educate the whole person and not just the mind. Donahue (1990: 54-55) outlines seven characteristics of a Jesuit education:

1 A sacramental view of life in the world which entails that God's grace is at work in human activity.

2 Enabling students to develop a sense of justice in order that others are treated with respect as ends in themselves and not as means to other ends.

3 To give priority to the notion of service in the doing of God's will.

4 The integral relationship between the life of faith and the life of the mind - faith and reason complement each other.

5 The education of leaders of faith for action in the world.

6 The priority and importance of the interior life or inner journey of faith.

7 The centrality of discernment in the development of knowledge and faith.

Discernment here is similar to good sense (practical wisdom). Its object is making decisions in the concrete reality of the world by following God's purpose and intentions. It involves a habit of prayer, mental reflection and experiencing the Christian life in community, and it involves the use of all our human capacities so that they respond to God's call to action. Therefore, the Jesuit Pupil Profile is really asking the question 'Who are you going to be in the light of who God calls you to be?' (Donahue, 1990: 57). It encourages a sense of vocation and ultimate questions on what kind of person we desire to be, and it gives emphasis to the notion that we discover God, not by fleeing the world, but by becoming more fully involved in it. Discernment also directs us to enhanced purpose, which is constitutive of leadership; for without it, leaders lead nowhere. It also posits holiness as the aim of education, not simply moral character.

Profiles like the Jesuit Pupil Profile are not unique within the Christian community, but they focus students on what beliefs they ought to hold and how these beliefs are developed through practices which in turn produce virtues. Beliefs and practices change who we are from inside so that we grow the virtues. For example, 
belief in God leads to the practices of prayer and worship, which lead to the virtues of hope, love, humility, joy and many others. If we truly believe in compassion, then we will offer our time to others, and this will manifest itself in the virtues of kindness, goodness and patience. Courses on building Christian character generally recognise that our language of the moral life is limited by time and culture and that God is both imminent and transcendent. Through discussion, mentoring, evaluative feedback from others and self-examination, the whole process challenges the student to assess his or her life. We cultivate our character intentionally in this educational process through the support of the school community. The process provides meaning and purpose to what we do in order for us to bear new fruit through God's grace as it helps us to name the virtues, recognise their strength for change in our lives, and gives us a clear view of ourselves. What sort of character portrait do we see? What sort of character portrait does God want to show the world through us? Asking questions such as these means that we are not wholly concerned about decision-making in the moral dilemmas we face, but rather in becoming the sort of person we ought to become. To ask the student 'What kind of person are you going to be?' is prior to their individual decisions of what to do, because the answer will determine how they see the moral situation and how they ought to respond. It places focus on the vision of the ideal human life and therefore the transformation of the entire person, not just their individual actions. To be a Christian is to be shaped by the virtues, commitments and worldview of the community of faith to which we belong.

The German Jesuits have also constructed a programme for character formation and have used the Jubilee Centre's framework as the inspiration for their Christian approach (see Zimmerman, Gentner and Spermann, 2020). Their programme states that Jesuit education has always been about forming the heart and the character of the student, particularly in encouraging them to ask the question: 'What potential is lying dormant within me and wanting to be aroused?' This virtue and character education programme emphasises the autonomy of students while insisting that virtues are taught in Jesuit schools. The programme notes:

The thinking of Ignatius and his companions was basically influenced by the Aristotelian concept of virtue ethics. It is therefore logical to adopt virtueethical approaches based on Aristotle's ideas when developing practical models for education at Ignatian-type schools. The aim is to be able to accompany young people more purposefully on their pathway of moral learning.

(Zimmerman et al., 2020: 20)

Another successful virtue education programme is The Disciple of Christ, Education in Virtue; a Christian curriculum structured on the teachings of Thomas regarding the virtues and gifts of the Holy Spirit (Rasmussen, 2012). This programme is specifically designed for Catholics. It aims to provide a consistent structure for instruction on the virtues to guide in the development of habits necessary to live as disciples of Jesus Christ. It aims to understand the meaning of the virtues and gifts, 
which in turn helps us to be more equipped to respond to God's love and grace. Cultivating a life of virtue, it says, gives one the ability to break the pattern of sin. This curriculum emphasises Christian discipleship as an indispensable element towards human flourishing and the quest for joy found only in living a virtuous life free from sin, and it firmly conveys the message that happiness is found only in a life of holiness. The programme starts with infants and claims that even they can learn the vocabulary of virtue as well as live the virtues and be witness to them. In a school setting, the call to discipleship is extended not only to the students, but also to their parents and the staff. The programme is the work of some Dominican sisters from Michigan, who have published for sale a large range of resources for virtue education in Catholic schools. These Dominican sisters are teachers, and they began their work on Christian character virtues in 1997, following the work of Thomas. The whole approach is premised on the idea that it is faith that calls us to strive by grace to be our best selves, for the love of God and others. The moral life, then, is not simply a matter of following moral rules and of learning to apply them to specific situations: the moral life is also a matter of trying to determine the kind of people we should be and of attending to the development of character within our communities and ourselves. In this, the virtuous person is truly happy because he really 'loves and does what he will' (to borrow Augustine's words).

Another example of a Catholic organisation providing resources for Catholic schools to help them focus on what is unique about Catholic education is the Cardinal Newman Society in the United States, which has translated key Church teachings into five helpful principles of Catholic identity. The argument motivating these principles is that schools have become too utilitarian and have lost sight of the whole person as well as a complete understanding of the purposes of education. Those principles recommend that Catholic identity:

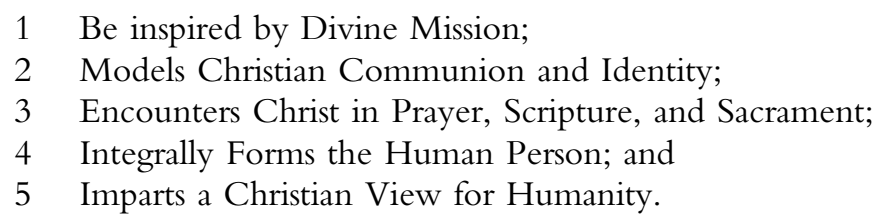

All of these principles involve encouraging dispositional standards that form Christian character, where 'dispositional' is understood as the motivation of a prevailing tendency or inclination in our character and concerns our dispositional capacity for reasoned choice, for showing how things are, or for making things. The Newman Society outlines these dispositional standards along the following lines:

- Involves the integral formation of the whole person, body, mind, and spirit, in light of his or her ultimate end and the good of society.

- Seeks to know and understand objective reality, including transcendent Truth, which is knowable by reason and faith and finds its origin, unity, and end in God. 
- Promotes human virtues and the dignity of the human person, as created in the image and likeness of God and modelled on the person of Jesus Christ.

- Encourages a synthesis of faith, life and culture.

- Develops a Catholic worldview and enables a deeper incorporation of the student into the heart of the Catholic Church.

There are some Catholic dioceses that promote an explicit Thomist approach to education as can be seen in the following statement of goals from the 'Schools Curriculum Foundation Document of the Diocese of Marquette' (2014):

The greatest happiness a person can attain is communion with Jesus Christ. Therefore, the core of our curriculum is the person of Jesus Christ. We hope to graduate students who have 'encountered the living God who in Jesus Christ reveals his transforming love and truth. This relationship elicits in the student a desire to grow in the knowledge and understanding of Christ and his teaching. In this way, those who encounter Christ are drawn by the power of the Gospel to lead new lives characterized by all that is beautiful, good and true; a life of Christian witness nurtured and strengthened within the community of our Lord's disciples, the Church.' Furthermore, our curriculum seeks to form our graduate's character, aiming as high as its perfection. A person of character is someone who within their personality unifies and develops the powers of their soul through the help of grace: to seek and to know the truth through the exercise of their intellect and memory; to choose the good and act according to it through the use of their intellect and will; and to be informed and inspired by all that is beautiful through the use of their intellect, imagination and passions.

It is noteworthy here that virtuous passions are to be formed through teaching (see Harak, 1993).

Another example of teaching virtue education is the classical education movement in the United States. The purpose of classical education is to cultivate virtue and wisdom through a tailored curriculum that develops character. There are secular and Christian versions of this classical education movement, each establishing their own charter schools at both elementary and high school levels to provide parents with the option of a classical education for their children. There are over 200 Catholic schools that have adopted a classical liberal education programme that focuses on the formation of the mind of the student. They teach how to read, how to think, and how to speak and write as part of an integral human development approach and employ the very best of the Western tradition as the content of the curriculum. The aims are intellectual growth and excellence in character, which enable the student to better know, glorify and enjoy God. Learning, in this scheme of things, is seen as a way to cultivate the student's soul towards holiness. Classical Catholic education integrates all teaching in Christ to lift all learning and knowledge to the realm of eternal meaning. Knowledge is 
valued for its own sake in this classical education approach, and the focus is on the education of the whole person. Students in these schools are exposed to art, literature, classic philosophy and the sciences in order to nurture the 'divine spark' which classical education advocates claim we possess. They further claim that classical education lays the foundation for learning by providing students with tools to learn that prepares them for self-governed learning. Classical education seeks to avoid moralism or the idea of 'fixing the kids', but it is easy for outsiders to misconstrue classical schools as being dedicated chiefly to uniforms, strict homework policies, discipline and standards. However, whilst all of these schools also have high expectations for academic attainment, their main aim is to revitalise the intellectual tradition of a Christian culture through their students acquiring the cardinal and theological virtues.

Christian Miller (2014: 230-239) usefully offers several formational strategies for developing virtue that fit well with the teaching strategies employed by the various Christian approaches outlined above and that he takes to have some prospect of success. He argues that if the goal is to become virtuous, we ought to begin by recognising that children and adults fall far short of being virtuous (or vicious) persons. First, he recommends that we should imagine people who are models of virtue (here we might think of the saints or good role models) and ask what they would do in our circumstances. Second, our conversations should speak more often about, and use the language of, moral norms. Third, we should seek friends and situations that not only allow, but also encourage, us to act virtuously. Fourth, on a psychological level, we should make ourselves conscious of what impedes our progress in virtue, for example being conscious of our many temptations, and he suggests that we should make every effort to develop behaviour patterns that subconsciously prime our virtuous responses. Fifth, he encourages us to transform our positive local virtues that we often display towards our friends and family into global virtues for the good of all humanity.

MacIntyre (1987: 16, 24) argues that a key purpose of education is supporting students to think for themselves, but he states that it is a familiar truth that one can only think for oneself if one does not think by oneself. The suggestion here is that one must read widely in order to think, because in that way you are thinking with others. Interestingly, MacIntyre believes that the fixation schools have with measurement does not support students in thinking for themselves. Whereas liberal education is about cultivating practical wisdom, it therefore stands apart from many modern schools that appear charged with maximising individual autonomy and freedom, as if the only goal of education is liberating the student from every imagined form of coercion. The Meditations of Marcus Aurelius provides a good method to extend a liberal education that helps liberate us from these egotistical and excessive passionate tendencies. As Hadot (1995: 201) comments, we 'get to see someone on the process of training to become a human being'. Each day Emperor Marcus Aurelius examined his conscience in an attempt to live the ideals he espoused in the written prompts upon which he meditated upon. These daily mediations, according to Hadot (1995: 20) constitute a 'discourse that intends to 
form more than inform'. Like Aurelius's Meditations, student personal diaries or journals are a good form of this self-reflection that schools can encourage as they offer spaces in which students can record feelings, attitudes and emotions as well as character traits upon which to reflect.

The key message in these virtue education approaches to building character is that virtue is manifest only in its practice within communities or with others - it must go beyond reflection. Christians need to be formed in the practices of the life of Christian faith. Students learn virtue through engagement with the practice of virtuous action, and the community is necessary for this to happen. It cannot simply be a discussion of ethical problems in the classroom in which there is a tendency never to reach a resolution. The students and the whole school community must become active in practising the virtues, which involves engaging in them personally. When students participate with others in virtuous practices, particularly with those who are more advanced and skilled in the performance of these practices, they are taught by example. This is reinforced when the people they engage with are personally significant in the student's life and when these significant exemplars see the student as significant in their lives too. Through the ever-expanding concrete practice of the virtues in school life, the student learns to explain these practices and how they relate to each other. They ultimately seek and take responsibility for 'initiating, pursuing and sustaining' these practices and are therefore able to guide and teach others in due course. Dykstra (2003: 176) suggests that this process should be a naturally occurring part of the Christian life, but increasingly today needs to be planned and systematic. Budziszewski (2017: 34) sums up the process:

The best way to improve the odds of getting virtuous people in positions of influence is to encourage virtue in everyone, raising all in good habits from earliest childhood, confirming them in these habits by sound laws, providing explanations little by little as their minds become able to reflect on experience and receive the form of prudence - explanations which do not substitute for these laboriously acquired dispositions, but which purify, ennoble, and direct them, helping their bearers to piece together what they were taught is actually right.

Schools that have an explicitly stated purpose and vision can more effectively cultivate character - that is, schools that make clear what they believe and how their beliefs drive action in the school.

\section{Suggested reading}

Donahue, J. (1990) Jesuit Education and the Cultivation of Virtue, in O'Brien, J. W. (ed.), Jesuit Education and the Cultivation of Virtues, Washington DC: Georgetown University Press.

An excellent Jesuit view of virtue and character. 
Mattison, W. C. (2008) Introducing Moral Theology: True Happiness and the Virtues, Grand Rapids: Brazos Press.

An account of the cardinal and theological virtues presented in a non-technical language.

Peterson, C. and Seligman, M. (2004) Character Strengths and Virtues, New York: Oxford University Press.

A view from positive psychology on the importance of character virtues.

Porter, A. (2017) Jesuit Pupil Profile, London: Jesuit Institute.

An interesting curriculum development in virtue that should be read in conjunction with Personality Formation on the Basis of Ignatian Pedagogy by Tobias Zimmerman, S. J., Humanimus Plus, Germany.

Ozolins, J. T. (2013) Aquinas and His Understanding of Teaching and Learning, in Mooney, T. B. and Nowacki, M. (eds), Aquinas Education and the East, New York: Springer Dordrecht.

Part one of this book addresses Thomas and his educational theory.

\section{Questions}

Are some virtues easier to practise than others?

What qualities of character does a teacher need?

Why is the moral character of a school leader so important?

Why is character hard to define?

Which, if any, virtues are particularly Christian?

What is the relationship between the theological virtues and the cardinal virtues?

How is a Christian understanding of generosity distinct from a secular (or classical) understanding?

What is the role of the intellectual virtues in Christian character formation?

What does it mean to have a connatural knowledge of the virtues?

What does the goal of preparing students for 'citizenship in Heaven' mean for teaching the civic virtues?

What is wisdom for a Christian?

Is there a role for assessment in Christian character formation?

What is the role of critical thinking in Christian character formation?

What would be the marks of a school which emphasises intellectual or performance virtues over moral ones? How do these stand at odds with the Christian tradition? What elements of the Jesuit or the disciple of Christ profiles do you find most helpful? What you could adopt or adapt for your own school context? 


\section{Chapter 6}

\section{A theological framework for character formation}

Nothing about being is more 'me' than my character. Character is the basic aspect of our existence. It is the mode of the foundation of our 'I', for it is character that provides the content of that ' $\mathrm{I}$ '.... It is our character that determines the primary orientation and direction which we embody through our beliefs and actions.

Stanley Hauerwas ([1975] 1995: 203)

This chapter seeks to provide a conceptual framework for character formation that is derived and inspired by an Aristotelian-Thomist understanding of human nature and education. It outlines a system of ideas and beliefs that can be used to plan and discuss an approach to character formation within the context of a Christian anthropology. It is premised on the argument that a distinctive educational philosophy and theology emerges from the application of Aristotelian-Thomist principles. This framework therefore outlines a distinctive educational model and provides a vocabulary by which to examine and refine an approach to Christian character formation.

It offers a particular rationale for Christian character education/formation as well as some of its practicalities by: (1) outlining how character formation is understood, (2) identifying some learning objectives, (3) explaining the core educational activities of teaching and learning and, (4) describing the organisational context in which character formation is structured, implemented and experienced. Christian character education or formation is primarily a guide to faithful Christian living. Formation takes many forms and operates in diverse situations. There is no blueprint, but there are some fundamental considerations. This framework builds on these considerations as expressed in the content of the chapters in this text.

The Aristotelian-Thomist educational approach has distinct philosophical and theological presuppositions, content, goals and methods with normative commitments that are profoundly at odds with modern culture. Fundamentally, the Aristotelian-Thomist tradition affirms epistemological realism: we have knowledge of reality, originating in sense experience and developed into the conceptual realm so that we truly can know real things and understand them according to their nature. This realism contrasts with views that hold that we are only aware of our subjective states, or that all thought is relative to some scheme, or that what we call 'knowledge' is really a social construction. This realist framework, together with 
an authentic philosophical anthropology, provides the resources to integrate cognitive and emotional elements in a development-oriented approach to character. That approach covers both principles that can guide one towards the right thing to do and the virtues that show what sort of person we ought to be in order to do, and want to do, the right thing. It also leads to the development of a sense of being which involves a concrete way of living well. This philosophical and theological approach is presented here as a distinct option for Christians, offering a traditionbased and pragmatic theoretical framework for conceptualising Christian character formation. It is not intended as a retreat from the world, or a return to the past, but rather as a way of engaging reality as it is and living in the light of a correct understanding of it as that relates to human nature and human fulfilment.

\section{Created in God's image}

We are human beings, with a spiritual and immortal soul, gifted with intelligence and free will and made in the image and likeness of God. If we love God then we must love other humans whom God has created as each is an expression of His nature, an imago dei. Each person bears the dignity of being made in the Image of God, and this dignity is promoted when, aided by grace, we choose to perform good human acts. Thomas taught that we are created with distinctive rational and spiritual powers that mirror the divine nature of God. Every human being has the capacity to know and to love God, but the Christian needs to work with Divine grace to remedy the misuse of the gifts of intelligence and freedom. Properly received, developed and exercised, these enable us to love what is true and good, and in doing so our freedom grows as we are liberated from ignorance and compulsion. If there is no freedom at all, we cannot speak meaningfully about moral responsibility. Our ability to know and love God can be distorted through sin, but can also be restored through grace. God's gracious nature provides the moral foundations for what is good, and God's image is seen in our character and in what we are destined ultimately to become. As humans, we are always in a state of Godgiven potentiality, and the acquisition of virtues transforms us, not simply through gaining philosophical wisdom, but by becoming more Christlike. In considering how to build character, the Christian faces fundamental questions: 'Who am I?', 'What sort of person should I become because I believe in Christ?', 'How should I live?' The formation of character in light of answers to these questions is one of the most important tasks in anyone's life as a human being.

Christian anthropology elaborates the meaning and importance of three basic Christian assertions: the human being is an image of God; Christ died for the redemption of humanity; the human being is called to an eternal destiny of communion with God in heaven. First, because every human being is created in the likeness and image of God, they possess a unique dignity deserving of respect. Second, because sin alienates us from God, we cannot reach perfection in this life or even proceed towards it without grace. It is also sin that disrupts our relationships with one another. Third, while sin darkens our sight, unsettles our desires 
and weakens our will, sin and its effects can be diminished and ultimately overcome through Jesus who invites us into a relationship with God. Yet although the ability to act virtuously comes principally through grace, it is not without cooperation and effort. While we are still weakened by sin we can be assisted and healed by God's grace, for God calls everyone to think, discern and to do what is good. The very possibility of being a person of Christian character in mind and spirit only exists because all human beings have been called by God to do some definite service. As St. John Henry Newman describes in the following extract from a prayer he wrote entitled The Mission of My Life:

\author{
God has created me \\ to do some definite service \\ which he has not committed \\ to another... \\ He has not created me for nought \\ I shall do good \\ I shall do his work... \\ I have my mission.
}

\title{
Becoming what we are
}

The notion of Christian character envisaged in this framework transcends the temporal, the material, and the secular and points towards the eternal, the spiritual and the religious. It is not simply about what ought I to do, but also what ought I to be and become. Christians are called by God 'to be conformed to the image of his Son' (Romans 8:29-30). Christian character is the possession of those qualities which are essentially Godly - and thereby 'goodly'. Human beings have a natural inclination to follow and pursue the good; in other words, we have a natural capacity to discern between good and evil. Good is done when a person acts in a way that is authentically human, and a good life makes flourishing possible. It follows therefore, that the mind that is illuminated by God's grace and guided by reason will grow in good character. This transformative process is ongoing and lifelong and requires an openness, willingness and commitment to be so transformed.

The moral virtues of Christian character have an objective reality that does not depend on any individual's or group of people's opinions or beliefs. They are not good because we approve of them; rather, we should approve of them because they are good in and of themselves. God's dealings with humanity provides the framework for understanding the conditions of human life. What God wills for a human being can be known, at least in part, by the observation of these conditions. Christian virtue education is to live the faith by growing in virtue, dispositions animated by love. Virtues are the reason that a person performs good actions more easily, and they are a sign and cause of a person's goodness. 


\section{Christian philosophy of education}

If we claim that education prepares human beings for life and forms character, then it follows that we need to have some conception of what the purpose of that life is. The main goal of education is therefore to help human beings fully realise their nature as rational and spiritual beings, premised on a theistic philosophy of education underpinned by the following principles that influence how character is formed:

a God created everything that exists, including human beings, which confers an objective order on reality in which we have the capacity to know and understand. Reality is intelligible and the basic requirements for good character are therefore accessible to human reason.

b All human beings share a common nature which participates in spiritual and material realities, but their character is differentiated, changing over time through various stages of life.

c Every person's life is an expression of purposeful movement towards a goal, and the moral norms that form character are discernible through reflection on this goal.

d These moral norms are grounded in human nature, and human beings cannot flourish or be genuinely fulfilled if they ignore them.

e Education is the complete formation of a person through the realisation of certain potentialities that lead to a mature character.

f Human flourishing is always the end of individual human action, and the good life depends on reasonable action exercised by good character.

$\mathrm{g}$ The human being is a free moral agent and responsible for the actions of their character.

$\mathrm{h}$ There is an indelible core of goodness and dignity in each human person.

$\mathrm{i}$ While the good life is the purpose of human life in this world, there is also the higher purpose of the Beatific Vision.

$\mathrm{j}$ Education aids human beings to experience being in the presence of God.

$\mathrm{k}$ Human beings act more humanely when reasoning, but this is always incomplete and imperfect.

1 Christian conscience is formed by fundamental virtues, particularly faith, hope and love and is essential to good character.

$\mathrm{m}$ The good life consists of intrinsically excellent activities - the virtues that education cultivates and which constitute character.

$\mathrm{n}$ The intellectual virtues should aid the study of logic, critical thinking and the scientific method, and education should teach students to understand reality.

Character education prepares human beings for life, and, as stated above, the main goal of education is to help us become full human persons. The educational process behind this formation becomes a practical expression of one's theological commitments as a Christian and will influence how we believe, think, learn, act and treat 
each other. Education aims to foster the highest degree of excellence in those who receive it. The most important agent in the educational process is not the teacher, but the student. The goal of education is a life-long process of learning how to (re) turn to God. Therefore, the primary aim of Christian formation is to assist students to become more faithful followers of Christ. Character virtues are needed to help us act in certain ways as disciples of Christ as the virtues enable us to act well and help us know and desire the good. Christian morality consists of living life with guidance and inspiration from the Christian scriptures, tradition, human reason and experience. Christianity offers its followers guidance for living a moral life through its observances, beliefs and expectations. Being virtuous and of good character are the first steps to the acquisition of 'Wisdom' in a theological sense. Theology is the wisdom which explains, defends, judges and guides this process of character education. In this respect, it directs and empowers Christian character formation. Theological wisdom is shared through faith in a Trinitarian God, and it offers an intelligent perspective that is higher than philosophical wisdom.

Theology therefore provides a vision and conception of the good for human beings. Within the Aristotelian-Thomist framework, Christian theology commits the educator to a number of claims including: the existence of God; belief in the afterlife; belief in a telos for humanity; belief in the Holy Spirit and in the Christian claims about Jesus Christ. These all have an impact on the formation of Christian character, and without such claims becoming beliefs there cannot be an authentic Christian character formation. They make a difference to what we believe and to what we teach. However, these claims are not necessarily realised in a merely nominal Christian context: in an institution that calls itself 'Christian', through education by teachers who are Christian or education received by students who are Christian. It is possible that (humanist) character education can be provided in a Christian environment without any attempt to integrate faith and learning. This is seen in Christian schools which commit themselves to loose and vague ideas of generalised 'gospel values', 'social justice' and other egalitarian sentiments that are not explained within a Christian theological framework. Christian character formation is more than simply living harmoniously and helping us socialise.

Vague generalities are a poor substitute for explicitly stated Christian virtues. These lead to a surreptitious secularisation process in which the natural virtues are prioritised and celebrated while the supernatural virtues are given lip service and consequently become unnecessary or are seen as irrelevant. They also lead to a distinct pedagogy in which the student is encouraged to think that there are no objectively right or wrong answers in life, just important experiences in which you decide for yourself what is right for you, and, crucially, in which you are taught to remain at all times 'non-judgemental' and 'open' to all views. While this may sound caring, it is in fact damaging: it is critically important to distinguish between being open to persons and being open to whatever persons may think or feel, since part of what is at issue in respecting persons is respecting the human need for truth.

By laying out a roadmap, this educational framework is clear on what is expected of all involved. It acts as a guide as opposed to a blueprint, and it must 
take the claims of culture and the uniqueness of individuals into account. This framework is not intended to describe an ideal expression of the excellent person. It is not concerned with producing clones. As a framework, it offers a lens through which one may discern different solutions appropriate to different stages, states and conditions along life's journey.

\section{Character virtues}

A really successful life consists in living the virtues, that is, in the love of the good and the practice of doing it. Knowledge of the good alone does not lead to commitment to doing the good. There is a wide gap between knowing and doing. Character is not secured through an intellectual education. Human beings need more than information - they need motivation, which faith can provide. The living out of moral character consists in the exercise of the moral virtues, and this is ordinarily dependent on understanding and prudence. However, the Christian moral life must always constitute a personal encounter with God - an intimate relationship with the Divine through Christ and the Holy Spirit. This can only be achieved through prayer and spiritual renewal that allow the Spirit to work within us. Consequently, we can gain a special knowledge, a kind of instinctive moral understanding, which is gifted to us by the Holy Spirit who potentially enters into the soul of every human being and transforms their actions and character. Christian wisdom goes beyond acquired knowledge; its capacity extends to the correct application of knowledge so that we can possess good sense and good judgement.

Freedom is both necessary and integral to character education as we need to develop the capacity to act voluntarily, consciously and intentionally. Authentic freedom cannot be reduced to a 'freedom from' what limits our personal autonomy, because our choices can go astray. Authentic freedom is a 'freedom for' flourishing and good character, a stable orientation to our ultimate good. Freedom for the Christian is not used to satisfy themselves or an end in itself. Christian character formation is not a mechanistic or static process, nor is there an earthly end-point, since the Christian life is always in process - always 'on the way'. It is about growth and maturation, renewal and inner personal conversion, and it requires that we are aware of the gap between knowing and doing. The Christian seeks help through prayer and counsel and co-operates with the Holy Spirit with intentionality and effort to address the faults and gaps in their character. They seek to choose purposively by evaluating alternatives and considering consequences before they act, and this depends on nurturing and strengthening character virtues.

\section{Teachers of character - Christ as the ultimate teacher}

Parents are the first educators of their children; other agents and institutions share this duty in a secondary sense. Teaching is a vocation, essentially a calling by God to serve humanity, in the first instance in the persons of their own children, for those who have them, and secondarily in the persons of the children of others. Properly 
received and understood, it should be motivated by a love of truth, of God, and of others. It is a distinct Christian vocation since Christian virtues require a robust concept of the moral exemplar as manifested in the Christian teacher who allows the student a way of knowing what the virtues actually look like. The more the teacher conforms to a Christian ideal of character, the more willing the student will be to accept this ideal. There ought to be at least three things in the character of teachers: first, stability, in that the teacher must not stray from the truth; second, clarity, in that they must teach without obscurity; and third, purity of intention, in that they seek God's glory and not their own. The Christian teacher is an educator who helps form human beings by improving them in knowledge and skills consonant with their true nature, ultimate end and highest good. The teacher's role is to bring about the synthesis between faith and experience, faith and culture, and faith and life. The teacher guides and encourages students towards eternal realities. Students see good character acted out and come to admire goodness in those significant in their lives - their teachers. The Christian teacher cannot simply fulfil a functional role, but must believe and practise the Christian faith. This is why the teacher must speak the language of virtue and show that good character lives in their actions.

\section{Teaching the whole person}

Christian education is a continuing voyage of learning and discovery that ultimately returns human beings to God. Christian education educates the mind to know the truth, and this in turn forms the entire person - because knowledge of the truth leads to living for what is good and appreciation of what is beautiful. The formation of the whole person recognises the innate dignity of the student. It also recognises that growth in character requires the need to be secure in faith and selfidentity. Character formation promotes personal vocation and connectedness to Christian tradition, cultivates the heart, forges the will and shapes character in virtue. It is built within communities that exemplify, in word and deed, the Christian virtues. A person of character is someone who unifies and develops the powers of their soul through the help of grace. They seek to know the truth through the exercise of their intellect and memory, and choose the good and act according to it through the use of their intellect and will. Ultimately, the Christian school seeks to help students to become saints.

\section{Schools of character}

Christian schools are extensions of the Christian family and are an integral part of the Christian community. The Christian school is at the service of theological motivations and goals as it strives to assist students in the formation of their character based on their relationship with Jesus Christ. This Christ-centred character formation is ultimately at the heart of every member of the school community. A school that has an authentic and forthright Christian ethos has a profound influence on the 
development of a student's character. This ethos is derived from those living and acting in accordance with the Gospel, which provides the background for the school's more explicit character formation programme. It is an ethos of engaged rationality in which reasons are given and exchanged for why something might be so. Formation in the virtues is not simply about listing certain virtues to be learnt, but requires that they be situated within a concrete social context that provides students with real-life examples of how their actions can affect themselves and others. C. S. Lewis, like Aristotle, writes Meilaender (1978: 212), 'believes that moral principles are learned indirectly from others around us, who serve as exemplars. And he, like Aristotle, suggests that it will be extremely difficult to develop virtuous individuals apart from a virtuous society'.

Academic excellence is an important goal of a Christian school, but is not sufficient to form a well-rounded character. Schools must join with parents to develop in their students an enduring character - that is, lives formed and fulfilled in accordance with faith. This involves nurturing the knowledge of moral goodness through the virtues, encouraging the desire in students to be a good person by doing the good, and developing a well-formed conscience as part of their character. Students need to understand the reasons why they should be good and experience some of the practical ways in which they can be good. Character education aims to motivate in them the desire to act in the service of goodness - knowing what to do, wanting to do it, and doing it. A virtuous person can never do something wrong or evil in order to bring about good; indeed, they will know that it is better to suffer evil than to do it. The Christian school will teach students to come to know the truth about life, the world and God. This does not happen at random, but rather is intended, planned and implemented. It requires vigorous effort and leadership to embed and embody a theology of character formation in a Christian school.

According to Rowland (2003: 70): 'a Thomist institutional ethos requires not merely the fostering of virtue-requiring and virtue-engendering practices in the Aristotelian sense, but also practices that are sacramental'. The Catholic sacramental imagination gives a coherence to the formational process. Not all reality can be scientifically observed, and yet that which is unseen is real and affects our inner formation. Thomas claims a radical and dynamic relationship between the natural and supernatural realities, between the visible and invisible realms, and he believes that the sacramental is essentially made present in the material world to enable material realities to serve as sources of spiritual wellbeing. This sacramental realism makes us ever conscious of the supernatural realm and connects the material with the eternal, thereby sanctifying humanity. The Sacraments are instituted as causes of grace with the theological virtues of faith, hope, and love. As Thomas says:

a sacrament properly speaking is that which is ordained to signify our sanctification. In which three things may be considered; viz., the very cause of our sanctification, which is the Passion of Christ; the form of our sanctification, which is grace and the virtues; and the ultimate end of our 
sanctification, which is eternal life. And all these are signified by the sacraments.

(ST. III, q. 60 a3.)

The sacraments are the footsteps towards Christ - real and tangible encounters with Christ and his sanctifying life through grace. This framework therefore incorporates the dynamic exchange of grace between humanity and God. It is about the learner seeing a vision of reality through their education as the place where God dwells. The Christian school is conscious of its role in promoting virtues to all of its members so that they may live faithful to the story of Jesus found in Scripture.

\section{Christian practical wisdom}

This framework is premised on the cultivation of Christian practical wisdom as an educational ideal and objective. Christianity is a living tradition that affirms the good and pursues educational goals that seek to nurture the good. Practical wisdom is the ability to render a proper assessment of a situation and to act rightly as a result. Aristotle calls it phronesis, which involves doing the right thing, at the right time, in the right way and for the right reasons. It is essentially about the exercise of perception, feeling, judgement and action by those who possess good sense. Christian practical wisdom is therefore premised on how what we believe as Christians forms and guides what we choose and how we act. It is concerned with understanding one's vision of reality and the nature of things and is constitutive of human flourishing. As Thomas would say, it is the right use of reason regarding things to be done, with practical wisdom configuring the ends of the moral virtues. It therefore requires knowledge and experience of Christian life to be able to choose and apply the right means, and the excellence of Christian character to define the right ends.

By the intellect, we can know what is good; by the free will, we can love and do what is good. Without wisdom, understanding and knowledge, no one can exercise the four natural virtues. However, we know that knowledge is more easily procured than understanding. This practical wisdom of the Christian life is gradually formed by enlarging the mind with multiple experiences, reflecting on them, and developing the imagination to creatively respond to those experiences with faith, hope and love. To see with the eyes of God.

Practical wisdom results in faith that is lived out in our actions, not in our abstract ideas. In short, it is about what we do in concrete situations which call on our ability to perceive the situation accurately before us, to have the appropriate feelings about it, to deliberate and discern in these circumstances, and to act. It depends on and requires us to learn and pray for certain Christian excellences: holiness, piety, fellowship, reverence, joy, spirituality, detachment, modesty, and so on. Ultimately, the virtues which are the free gift of God, particularly faith, hope and love, are visible and cultivated in Christian schools when there is trust in God, active belief, worship, prayer, service, working for the common good, 
justice, self-giving, forgiveness, humility, mercy and the witness of love. These are the virtues that form and inform the Christian conscience while also aiding the capacity to follow one's conscience.

\section{Christian fellowship - a journey with others}

Christian fellowship and common experience in the Christian community are invaluable resources for building character and making moral decisions. The main elements of this Christian formation come from prayer and worship, listening to and reading about scripture and Christian teachings, offering service to others, as well as engaging in teaching and learning. All of these elements inform, instruct and inculcate, and ultimately seek to form our entire being because the self that a human person becomes is largely determined by the free commitments he or she makes. The Christian knows he is a sinner and wholly dependent on God's grace and mercy; she knows that she needs to begin again (and again). He knows, as Augustine put it, that the foundation of the spiritual life is humility. Simply having these things in place in a school or having expectations of Christian behaviour do not make the Christian. The pastoral education and witness to the why behind these elements are paramount. Also paramount is a community that exudes joy - confidence in God - and warmth - affection for each person in that community. Again, here, understanding God's love and the experience of being loved are part of the motivation for returning to the sacraments to nourish, heal and strengthen us.

Christian character education encourages students to grow in the faith of their baptism; a faith assimilated and nurtured through contact with people inside a community - the Church. This living, conscious and active community of faith urges its members to adopt a Christian way of living and advances the common good. The Christian community enhances and strengthens the virtues of the individual Christian's character, as well as building a community of virtuous persons. The Christian narrative shapes the character of the Christian by moving them towards maturity so that choices can be rationally and consciously made in the light of faith. Christian education draws upon the successes of the Christian community in the past, learning from artifacts of Christian culture, including music, architecture and visual arts.

\section{The building blocks of Christian character formation}

Theology presents us with a clear scheme and summary of the virtues that are the building blocks of character. Christian character formation subscribes to the following fundamental and interconnected natural or cardinal virtues. These four cardinal or 'hinge' virtues represented the highest ideal of character attainable in the classical world, but were not sufficient for the early Christians who transformed their meaning and supplemented them through revelation and faith. These natural virtues are acquired through human effort, the 
theological ones are gifted by God, though whether and how they are received and exercised depends upon our co-operation with God's work in and for us.

\section{Natural virtues}

Prudence or practical wisdom is the ability to know what to do, how to act and what to say in order to be virtuous in any concrete situation. It is not simply about acquiring intellectual virtues, but relies on the insights into human nature gained through faith.

Justice is essentially about a relationship with your neighbour and is the desire to do what is right honestly and fairly. It is about living in harmony and cooperating with others. To respect all and give them what they are due is essentially about how to ensure the well-being of all.

Fortitude is consistency in the pursuit of the good and strengthens our resolve to resist temptation therefore helping us to overcome obstacles to a Christian moral life. It gives us strength to carry out the good we desire by acting on our convictions in the face of difficulties.

Temperance moderates the attractiveness of pleasure and provides a balance in our use of created goods by regulating our passions. It helps us control our desires for pleasure and helps prevent over indulgence by providing selfdiscipline.

These acquired virtues are accessible to all people and they are traditionally viewed as natural virtues that have a series or cluster of other sub-virtues attached to them and that flow from them, including: patience, sympathy, forgiveness, selflessness, generosity, and many more. The intellectual, moral and civic virtues are part of these natural virtues and may act as a preparation for a Christian character education. These natural virtues are real, and they lead and prepare for the theological virtues that are the foundation of Christian moral activity. Character formation ideally ought to be first rooted in these natural virtues as they are the preparatory virtues for a Christian character. Thus, we pursue the cardinal virtues because they express what minimally constitutes a virtuous person. They perfect the fundamental anthropological dimensions of being human that are needed for integrated virtuous behaviour. All aspects of virtue knowledge derived from the natural virtues must however be integrated in the light of faith. The theological virtues reinforce and strengthen the natural virtues, which in their natural state are incomplete and insufficient for life here or in the hereafter. Consequently, an education in character that is restricted to these natural virtues fails to be a Christian education. Such an education is limited, and while it may incline the person to some good deeds and even appears to promote the common good, it lacks the ultimate value and orientation provided by the theological virtues. A 'Christian education' that only focuses on the natural virtues subordinates the authority of the Christian tradition to human judgement and human relativities. Ultimately, Christ becomes a prophetic moral and religious teacher only and not a divine saviour. 


\section{Supernatural virtues}

The theological or supernatural virtues are (1 Corinthians 13:13):

Faith, the object of which is God; both belief in God and the truths he has revealed. Faith requires action and application to be understood. It is about discovering what God's will is and acting accordingly.

Hope is about placing trust in God and is the expectation of receiving something we long for. It is about trusting that God is always working for our good.

Love is unconditional love for all and is the core of the Christian moral life. The love of God above all things and love of neighbour and self for the sake of God.

How do the acquired moral virtues fit in the overall scheme of the Christian life? While the three theological virtues put us directly in contact with the goal or end of our life, the four moral virtues have to do with the means that must be used to attain that end. These theological virtues transcend the natural virtues because, for example, without love no one can totally overcome selfishness. They inform and give life to the natural virtues by elevating them to a supernatural level. They are also 'meta-virtues' because they are virtues that bring with them many other virtues and also the fruits of the Holy Spirit (Galatians 5:22-23) - love, joy, peace, forbearance, kindness, goodness, faithfulness, gentleness and self-control. The gifts of The Holy Spirit (Isaiah 11: 1-2) help facilitate the exercise of the virtues. They are:

Wisdom, which helps us recognise the importance of others and the importance of keeping God central in our lives. It is knowledge of 'divine things' and the capacity to judge human affairs according to divine truth.

Understanding, that is, the ability to comprehend the meaning of God's message and comprehend the truths that are necessary for our salvation.

Knowledge, which is the ability to think about and explore God's revelation, and also to recognise there are mysteries of faith beyond us. It is the ability to judge correctly about matters of faith and right action.

Counsel, the ability to see the best way to follow God's plan when we have choices that relate to him. It allows us to be directed by God on all matters necessary for our salvation.

Fortitude, the courage and confidence to do what one knows is right and avoid evil. Piety, which helps us pray to God in true devotion and in accordance with Scripture. It also involves due duty to all on account of their relationship with God.

Fear of the Lord, that is, understanding God is all-present and whose friendship we do not want to lose. Essentially, it refers to us revering God and avoiding being separated from Him as opposed to 'servile' fear whereby we fear punishment.

These gifts of the Holy Spirit dispose a person to be moved, not by their own reason, but by God. The fruits of the Spirit essentially manifest personal character traits. These Christian virtues help forge character and give facility to the practice of 
the good. A popular metaphor which describes a person being moved by God is likened to being a ship moved by the wind, with the gift acting as sails. Alternatively, the gifts are like the wings of an eagle that are swept up in a strong wind. In both metaphors, the Holy Spirit is the guiding wind and the intended message is simply that the action of the Holy Spirit in bestowing grace moves a person to right action. Growth in Christian character also requires progress in holiness and spiritual awareness as well as theological understanding, and this formation and transformation must be accompanied by some theological content. The Holy Spirit works in Christian lives and changes those lives gradually, he sanctifies them - that is, he makes them holy in their character through the theological virtues. The telos is to direct human beings through God's grace to the highest happiness and ultimate end, which is union with God. These natural and supernatural virtues are interwoven with the teachings in the Sermon on the Mount together with the Ten Commandments as a guide to live the Christian life. In virtue, Christian character education seeks to form the students who receive it and is ultimately concerned with students receiving the moral teachings and other traditions of the Church, appropriating them and responding to them.

\section{Christian learning objectives for character formation}

The formation of Christian character is about conversion and transformation, which require not passive learners, but active, engaged and reflective students. It is not simply about what we know or can do, but rather about how we are changing and what we are becoming. The understanding that underpins learning objectives, however, is generally drawn from secular models of learning that are premised upon specifying, in advance, learning outcomes in terms of observable changes in human action. These formational teaching strategies do not depend on a knowledge of God. Their focus is on the what and how of teaching, but rarely on the why. This ignores the Christian idea of being and becoming. It ignores the divine-human encounter as the source of character formation. The framework outlined here endorses critical rationality as one of the key goals of forming Christian character, which relies on literacy skills in reading and writing, as well as verbal reasoning, the ability to analyse arguments, critique opposing hypotheses, explanations and models to problem solve and make decisions. All of this complicated educational process takes place within a rich learning environment that honours, respects and grows student autonomy and freedom to bear Christian witness to their immediate culture.

The following objectives are a description of what it means to provide an account of character formation for students in a Christian school that follows the principles in this framework. Students require a broad and comprehensive approach to character formation that considers the environment, buildings, space, ethos, curriculum, teaching methods, together with teaching by example and providing realistic opportunities for practice. Each of these is incorporated into the approach, so that: 
- they come to view the human person and their character as created in God's 'image and likeness' and destined for eternal life; they are enriched by a Christ-centred education that reflects and understands God's purpose for their unique life and character;

- they come to view God as present and active in the world, particularly through relationships with family, friends and teachers, that impacts on their character;

- they are given a theological foundation for their thoughts and actions of character that enables them to make an intelligent and informed choice for themselves throughout life and before death;

- they develop spiritually by being instilled with a love for the Word of God, for Jesus Christ, God the Father, and his Holy Spirit, and a personal sense of responsibility to be all that God wants them to be;

- they develop at different stages from first external motivation (caught and taught character) to internal motivation (self-sought character);

- they experience the school as providing not simply information, but direction within an ethos in which they grow, understand, develop and integrate the natural and supernatural/theological virtues that build character;

- they are prepared not only to make a living, but also to live wisely by being encouraged to think clearly, logically and independently.

\section{Character formation as a pathway to union with God}

The essential aim of Christian character education is to educate a person to be a real person in a real and complete sense, not just to make a person a certain kind of professional person. The practice of all the virtues, natural and supernatural, is the essence of character, and having these virtues entails knowing when and how to exercise them. The natural virtues can be developed and function in a person's life independently of the grace-given virtues. A shared humanity includes a shared ability to reason, which means that all human beings can agree on what might constitute the common good. The Aristotelian-Thomist framework affirms the existence of moral goods that Christians and non-Christians may virtuously seek to realise. However, the Christian sees these moral goods in a world created by God and their motivation to realise these goods differs from the non-Christian, even when pursuing the same goods. The Christian acts from love of God and because both reason and religious faith inform their perspective about the good. There will be times when the Christian disagrees with the non-Christian.

Another way to understand this natural and supernatural approach to the virtues is to consider the purposes of a Christian school from virtue-rich horizontal and vertical axes. The horizontal axis represents the natural virtues (emanating from the cardinal virtues) of compassion, courage, reasoning, gratitude, generosity, and so on, that any Christian school will attempt to inculcate in their students in forming their characters. However, this horizontal axis does 
not make the Christian school religious or distinctive, as other schools can claim the same natural virtues without any religious affiliation. The Christian school requires a vertical axis of the supernatural or theological virtues of faith, hope and love. The belief in God and the practice of these theological virtues through prayer and worship are intended to work with the horizontal natural virtues to strengthen, reinforce and enhance them. Christian living, learning and prayer are interwoven, and in this Christian context there exist infused versions of the cardinal virtues which help us to live the Christian life. This process reveals the deeper purpose of character formation - we flourish best when our likeness is closest to the image of God. This is why the image of God becomes visible in the virtuous person (see Sullivan, 2021: 525).

Our actions are changed by changing our beliefs and thoughts about them. The Christian life is telic in the sense that it looks upwards to heaven to discern, through faith, purposeful growth. Ultimately, it involves love of God and love of neighbour as yourself, but it requires Christ's presence in us, which becomes the guide to moral decision-making. Living in a Christian community is not about making a series of difficult decisions each time one faces a dilemma. The living of Christian virtues in community can make decision-making less of a priority. These grace-given vertical virtues do not invalidate the horizontal virtues, but rather build upon and extend their scope. The two kinds of virtues must be continuous with each other, with the natural virtues being the foundation for the supernatural virtues. Pope (2014: 411) sees this process as a pilgrimage rooted in an image of human life as a journey to God:

The virtues are dispositions of heart and mind that help us negotiate this journey. Faith gives a deep sense of where we come from and where we are going. Charity provides the fuel of love for the journey and hope gives the courage to stay the course in the face of dangers, loss and disappointment.

The Christian also prays for help to grow in virtue, and this is evident throughout Scripture. We need the fortitude of Christ; we pray to increase our faith, and we need to listen to the Holy Spirit to grow in wisdom. The Holy Spirit penetrates and touches our very depths, transforming our actions, bringing them under its guidance rather than wholly relying on our own initiative (Cessario, 2001: 207). To live the Christian life the Christian needs to say with confidence: 'It is no longer I who live, but Christ who lives in me' (Galatians, 2.20). Through education in character we need to nurture the 'habitual readiness to flourish' (Sullivan, 2021: 522).

\section{Questions}

What are the implications of the fact that we are all made in God's image? What does it look like for teachers to be 'moral exemplars' for their students? What is the role of the Catholic school within the wider Church? 
What is the relationship, and what are the differences, between natural virtues and character virtues?

Consider the learning objectives listed above. How can these be incorporated into a school's vision for education? How will you know if the school is successful in meeting these objectives? 


\section{Conclusion}

Beneath every educational activity lie distinct anthropological commitments, including the significance of the virtues for character formation. Indeed, anthropological neutrality does not exist since modern educational systems will have their own idea of what a human being essentially is as manifested in their sets of values, sense of purpose, codes of conduct and educational goals. This is the case whether or not their understanding of human nature is explicitly articulated or merely implicit. It has been argued in this book that education in the West has largely lost an explicit anthropology for education and that in order to address this situation we can reliably draw on both Aristotle and Thomas. We can turn to both and learn from them within a Christian context.

Virtue ethics, we have seen, has three main concepts: excellence or virtue (arête), practical or moral wisdom (phronesis) and happiness or flourishing (eudemonia). Teleological virtue theory holds to a three-fold structure: who we are, who we could be and how we get from point A to point B. Good character requires activity - especially activity that exemplifies the virtues. The virtues both lead to and constitute the human telos in that they are not merely means. While Aristotle's ethics suffer from his era's aristocratic and hierarchical notions, they still have much that sharpens the Christian idea of character. We have seen that Aristotle believed that the good life consists of intrinsically excellent activities and that if we are to achieve the good life we must cultivate the virtues. We should therefore define and list these virtues and desirable qualities, and use our knowledge of teaching and learning to generate practical methods of transmitting these virtues. Consequently, we must design our pedagogy in order to produce concrete educational practices that cultivate and nurture character.

For Aristotle, human flourishing should be the natural end of individual human actions, and we require practical wisdom to choose the proper course of action in any given context. Autonomy is key since we possess the human characteristics of rationality and free will. It is a pre-condition for moral activity. The Aristotelian perspective holds that reality is objective, exists independently of the consciousness of human beings and has a determinate nature that is knowable. In this sense, wisdom is the intellectual virtue that perfects and completes virtues of character. This approach has core notions of the purpose of life, the good person, character 
and virtue that capture much of what can aid the Christian moral life. However, this approach is not motivated by Christian faith, for wisdom here is only obtained through worldly experience. Nussbaum (2001: 300) argues that this kind of approach to acquiring wisdom involves a quasi-perceptual capacity to see what to do. For the Christian, the ultimate source of wisdom is God and is the gift of being able to see everything with the eyes of God.

Thomas clearly capitalised on Aristotelian philosophy, fusing Greek ideas of rationality with Christian theology to produce a Thomist-Aristotelian system of ethical thinking. In this system, education is located within Thomas's complex understanding of the nature and destiny of the human person. He clearly understood that you cannot know what is good for a person unless you know what a human being is. Both Scripture and Church teaching set forth an understanding of human nature. Thomas offers a basic Christian anthropology - a conception of human nature which underpins moral virtue. He argued that theologically all human beings are created in the image of God and are a union of body and soul ordered to a preparation for eternal life. God is both transcendent and immanent and works through human nature offering grace. This Thomist anthropology emphasises the communal nature of the moral life in the Church and therefore seeks to balance the autonomy of the individual with the community of which they are part. This theological anthropology leads Thomas to the prospect of a philosophy of education.

Haldane (1989: 173), commenting on Maritain (1943), describes this Thomist philosophy of education as a form of 'naturalism' that is joined with a 'realist epistemology and metaphysics' and an 'objectivist theory of value'. Essentially, Thomas saw education as a process of formation that involved the realisation of certain potentialities. Each human being possesses a potentiality to know, and an inclination to find, the truth. Haldane (1989: 174) summarises this by saying that the two central concepts in a Thomist philosophy of education are the 'human person' and the 'human virtues'; where virtue is seen as an enduring excellence of character and where we can only promote good human lives by cultivating virtue. The destiny of the human person, as well as their relation to God and society, is vital, as is the way the human person comes to know themselves in this theory of education. The formation of the person depends upon guidance, and a person's good actions depend on their rational nature, as Crowe (1981: 87) says:

Natural law, for St. Thomas, the law of human nature, is essentially connected with the rationality that is the specific character of human nature. The natural law is the law of reason; the good action is the reasonable action, the evil what is contrary to reason.

The complete formation of a person is a life-long process involving many agencies, not least the family, Church and community. Christian virtue ethics focuses on the overall purpose of life, namely to live well and, with God's help, achieve excellence as a human person. Education is good for our nature and helps complete it by directing us to what makes us flourish and not simply what makes us useful. 
We have discussed how good actions are done by good agents who act according to their character excellences which enable them to live and function well in life. This process continues in schooling with character formation permeating the entire school and is therefore what the overarching goals of a school set out to achieve. This is described in the language of virtue that is not static; we continue to grow in virtue, and our understanding and practice of virtue change over time. Virtues are those characteristics that enable individuals to live well in communities with the purpose of achieving a state of well-being, eudaimonia. The question of how to live a good life cannot be separated from how we should act. Freedom is both necessary and integral to character education. If the moral law were simply a binding command imposed by God, then how could we choose to be moral? You cannot be a Christian without moral autonomy, but you also need to recognise that the Christian life is the completion of the moral life and that is why Christians freely choose to live this life. We have seen how the Christian life is essentially a preparation for union with God. Yet Christianity has no monopoly on moral judgement, and ordinary moral virtues, such as refraining from stealing and keeping promises, are common to all human cultures. The fact that moral virtues are not completely dependent on religious worldviews is reflected in the natural law that Thomas advocates. The power of the Thomist synthesis can be seen in how it has inspired social radicalism, popular apologetics, Social Action and in its confidence in the right use of reason that potentially leads us to God. However, for Thomas, virtue formation is not complete without Christ.

Living well demands the satisfaction of primary needs such as good nutrition and health, but this alone is not sufficient since there is a difference between having what it takes to live well and living well. A really successful life consists in virtue, that is, in the love of the good and the ability to do it. It requires us to be motivated to desire the good, an ability or capacity to do the good and a self-identification as a good person - in other words, a disposition to think, feel and behave in a virtuous manner. A virtuous person is someone who is truly happy because they love and do what is good even in moments of pain and suffering. The virtuous person does the good because they love it, not simply because they are commanded to do it. The education of character is an education in the moral virtues, and the school by itself is insufficient to form these character virtues. For Thomas, human beings are not static but rather dynamic and changing, for now ever advancing towards their end. Formation is needed more than ever to navigate through the moral diversity of this world because moral neutrality is impossible in the realm of human actions. As MacIntyre (1981: 263) writes:

The new dark ages are already upon us. And if the tradition of the virtues was able to survive the horrors of the last dark ages, we are not entirely without grounds for hope. This time, however, the barbarians are not waiting beyond the frontiers; they have already been governing us for quite some time. And it is our lack of consciousness of this that constitutes part of our predicament. We are waiting not for a Godot, but for another - doubtless very different - St Benedict. 
In the modern world, where there is no consensus concerning the human good, it is not possible for ethics to be justified in a united end for human life. If some conception of an end for humanity is proposed for modern society, such as freedom or happiness, it quickly becomes apparent that such a notion of the 'good' has little ethical content. This is because our society is based on the view that freedom involves the freedom to determine what form one's individual happiness will take. But then 'happiness', as an end or goal for human life, offers no practical guidance for the conduct of that human life. As Hauerwas (1995: 204) writes:

To be a Christian at least involves a particular kind of commitment to the right ordering of our existence and our character. It means that we are obliged to a certain 'way' of acting and that this 'way' is the actual determination of our character.

For Hauerwas (1995: 117), character is moulded by our intentions and beliefs as much as by our actions. Virtue is cultivated by actions and through interactions with virtuous people who are our examples. At the core of the virtues is service to others, which is both teachable and learnable, and so schools and teaching can only assist the work of the Christian community in this task. Advice about how to live and the virtues that we see in others and want to follow only make sense within a given philosophical-theological system.

Most educational systems in the West focus almost exclusively on skills and passing tests, rather than character formation. School education has been largely redefined as a matter of management, efficiency and cost-effectiveness. However, greater interest in human flourishing is slowly being incorporated into these educational systems through well-being, personal development and character education initiatives. Questions have been raised in these chapters about different ways of understanding human flourishing, which operate even when educators are not aware of them. They have shown that Christian education is premised on a particular understanding of human flourishing, which is derived from an understanding of human nature and built upon Aristotelian, Augustinian and Thomist foundations. We have examined how a Neo-Aristotelian-Thomist view of character and virtues can offer a framework for character education. This framework is characterised by objectivity that eschews subjectivism and scepticism. A case is made that a richer view of character education could be developed if one incorporated a more comprehensive view of human flourishing based on a higher view of the human person/human nature. There are different views of human nature that can be employed theologically to understand character formation, and there cannot be character without an ideal - philosophy, goals and the telos; in other words, ideals that guide human flourishing. A conception of the highest human good through a Christian vision of human flourishing is premised on the life of Christ and a conception of moral virtues as cultivated states, manifested by those exemplary persons in the Church who have come closest to achieving the highest human good - the Saints. A conception of moral virtues identifies human capacities that may be 
shaped and regulated by reason: minds to be educated; wills to be formed towards goodness; emotions to be shaped in harmony with mind and will. It promotes character virtues formed that enable us to act well with our capacities that are exercised for the benefit of society, with practical wisdom being the goal of character formation. Flourishing can be a goal on the natural level: achieving the greater perfection of these human capacities. On the supernatural level, the goal of perfection requires aiming at a higher goal (God), perfected through God's help (grace). Christian theology helps us to distinguish between acquired and infused virtues in understanding character. It also helps us understand the common good doing good to all, willing good in all. The first object of virtues is the common good that equips us to participate for the public good, and it is the social teachings of the Church which make it possible for us to live together in the right ways. Character virtues aim first and foremost at the good of the community, which is served through reasonable virtuous activity.

Christ provides a 'goal', an 'example' of human flourishing and character: this goal is union with God and one's neighbour through charity. The example is Christ himself, because he worked to help individuals flourish with bodily health and helped establish and shape a community in which supernatural flourishing could take place. The language of Christ, derived in part from Jewish Scriptures but also original in places, explains the nature of flourishing: 'be perfect as your Heavenly Father is perfect'; 'Love one another as I have loved you'; 'I have come that you might have life, and life more abundantly'. The early Church followed Christ's example and developed ways that individuals and communities might flourish: by teaching about human dignity (thereby affirming life in all its stages), serving the poor, witnessing to conscience, etc. This activity was an example of grace perfecting nature. Ultimately, by placing God in the centre of human flourishing, Christ (and subsequent Christian culture) ended by more powerfully encouraging human flourishing - seemingly a paradoxical result, but in fact appropriate, if God is indeed the highest good and the source of all flourishing, natural and supernatural. The Christian transformation of character - how shall we live (by faith, hope and love, and by the practice of the virtues) - provides the catechesis for Christian character education. The 'thick' content of this catechesis begins with virtue habituation into roles and responsibilities guided by Church teaching, examples and liturgy, under the right conditions: character taught and caught. With sufficient personal effort, this becomes increasingly self-directed, reflective and intelligent: character sought.

The thought of Thomas was dominant in Catholic educational philosophy until the middle of the twentieth century. However, with disagreements among Thomists, the development of different schools of Thomism and the changes that came about after Second Vatican Council, Thomism as a force in directing Catholic educational theory and practice has lessened, albeit its influence is still seen in the statements from the Congregation for Catholic Education. Thomas taught that, insofar as we believe anything, we should believe reasonably and that we should have evidence and reasons for our beliefs. He 
taught that we are animated by a desire for goodness and to become agents, albeit limited and finite agents, of goodness to ourselves and others. However, he also taught that we desire God and are capable of knowing God, even if this knowledge is imperfect, and that it is in loving God that we are ultimately able to live and express a well cultivated moral life. 


\section{References}

Adams, N., Pattison, G. and Ward, G. (2013) The Oxford Handbook of Theology and Modern European Thought, Oxford: Oxford University Press.

Adler, M. (1982) the Paideia Proposal: An educational Manifesto, New York: Touchstone Simon and Schuster.

Agnew, J. (2010) Deus Vult: The Geopolitics of the Catholic Church, Geopolitics, 15: 1, 39-61.

Akinwale, A. (2010) Integral Humanism and the Integrity of Education. A paper read at the International Conference on Education organised by the Council for Research in Values and Philosophy, Washington, DC and the University of Lagos, 19-22 April 2010.

Anderson, J. M. (2020) Virtue and Grace in the Theology of Thomas Aquinas, Cambridge: Cambridge University Press.

Anton, A. L. (ed.) (2018) The Bright and the Good: The Connection between Intellectual and Moral Virtues, London: Rowman Littlefield.

Aquinas, T. (1948) Summa Theologica. Translation of the Fathers of the Dominican English Province, New York: Benzinger.

Aristotle (1988) Nicomachean Ethics (Greek/English). Translated by Rackham, H.Cambridge MA: Harvard University Press.

Arthur, J. (2020) The Formation of Character in Education: From Aristotle to the 21st Century, London: Routledge.

Arthur, J. (2003) Education with Character: The Moral Economy of Schooling, London: Routledge.

Ashley, B. M. (2006) The Way Toward Wisdom: An Interdisciplinary and Intercultural Introduction to Metaphysics, Notre Dame, IN: Notre Dame University Press.

Ashley, B. M. (1996) Living the Truth in Love: A Biblical Introduction to Moral Theology, Staten Island, New York: Alba House.

Ashley, B. M. (1995) The Loss of Theological Unity: Pluralism, Thomism and Morality, in Weaver, M. J. and Appleby, R. S. (eds.) Being Right: Conservative Catholics in America, Bloomington: Indiana University Press.

Astley, J. (2018) The Naming of Parts: Faith, Formation, Development and Education, in Stuart-Buttle, R. and Shortt, J. (eds.) Christian Faith, Formation and Education, Cham, Switzerland: Palgrave Macmillan.

Austin, N. (2017) Aquinas on Virtue, Washington, DC: Georgetown University Press.

Austin, N. (2016) Spirituality and Virtue in Christian Formation: A Conversation between Thomistic and Ignatian Traditions, New Blackfriars, 97: 1068, 202-217.

Barrow, R. (2007) Plato, London: Continuum. 
Bauerschmidt, F. C. (2013) Thomas Aquinas: Faith, Reason and Following Christ. Oxford: Oxford University Press.

Baumert, S. W. (2013) Texts and Contexts: A History of Religious Education in American Catholic High Schools 1929-1969, PhD, Washington, DC: Catholic University of America.

Beck, A. (1961) Aims of Education: Neo-Thomism, Public Lecture at the University of Manchester 1961, published in Hollins, T. N. B. (1964) The Aims of Education, Manchester: Manchester University Press.

Beckham, J. and Titus, C. S. (2005) The Pinckaers Reader, Washington, DC: Catholic University of America Press.

Bejczy, I. P. and Newhauser, R. G. (2005) Virtue Ethics in the Twelfth Century, Leiden: Brill. Bennett, W. J. (1997) The Book of Virtues for Young People, New York: Simon and Schuster.

Berner, A. R. (2008) Metaphysics in Educational Theory: Educational Philosophy and Teacher Training in England (1839-1944), D.Phil Thesis. Oxford: University of Oxford.

Bigger, S. (2008) Secular Spiritual Education, Education Futures, 1: 1, 60-69.

Bizley, R. A. (2007) American Catholicism's Science Crisis and the Alberto Magnus Guild 1953-1969, Isis, 98: 4, 695-723.

Blanshard, B. (1973) The Uses of a Liberal Education, Chicago: Open Court Publishing.

Boland, V. (2010) Thomism, in Bevir, M. (ed.) Encyclopaedia of Political Thinking, London: Sage, Volume 3, 1361-1368.

Boland, V. (2007) St. Thomas Aquinas, London: Continuum.

Brady, W. O. (1928) Catholic Education, Religious Education, 23: 6, 540-545.

Bredin, H. (1972) T. S. Eliot and Thomistic Scholasticism, Journal of the History of Ideas, 33: 2, 299-306.

Brooks, D. (2015) The Moral Bucket List, New York Times, 11 April.

Brooks, D. (2015a) The Road to Character, London: Allen Lane.

Brown, J. A. (1940) Educational Implications of Four Conceptions of Human Nature, Washington, DC: The Catholic University of America.

Brown, W. P. (ed.) (2002) Character and Scripture: Moral Formation, Community, and Biblical Interpretation, Grand Rapids, MI: Eerdmans.

Brugger, E. C. (2009) Psychology and Christian Anthropology, Edification: Journal of the Society of Christian Psychology, 3: 1, 5-18.

Bruner, J. (1996) The Culture of Education, Cambridge, MA, Harvard University Press.

Budziszewski, J. (2017) Commentary on Thomas Aquinas's Virtue Ethics, Cambridge: Cambridge University Press.

Burnyeat, M. (1980) Aristotle and Learning to Be Good, in Oskenberg, A. O. (ed.) Essays on Aristotle's Ethics, Berkeley: University of California Press.

Cahill, L. S. (2002) Christian Character, Biblical Community, and Human Values, in Brown, W. P. (ed.) Character and Scripture: Moral Formation, Community, and Biblical Interpretation, Grand Rapids, MI: Eerdmans.

Callicott, J. B. (1990) The Case against Moral Pluralism, Environmental Ethics, 12: 2, 99-124.

Camosy, C. C. (2018) The Crisis of Catholic Moral Theology, Church Life Journal, Notre Dame University, 15 November.

Campbell, J., O'Rourke, M. and Shier, D. (2004) Freedom and Determinism, Cambridge MA: MIT Press.

Campion, R. J. and Horan, E. (1930) My Character Book: A Laboratory Manual for the Student of Religion, New York: W.H. Sadlier.

Cannadine, D. Keating, J. and Sheldon, N. (2011) The Right Kind of History: Teaching the Past in Twentieth Century England, London: Palgrave Macmillan. 
Capelle, N. (2012) The Religious Institute of Catholic Education: The Brothers of the Christian Schools in the 20th Century, International Studies in Catholic Education, 4: 1, 68-81.

Carr, D. (2004) Moral Development: A Reply to Richmond and Cummings, Journal of Moral Education, 33: 2, 207-210.

Carr, D. (1995) Towards a Distinctive Conception of Spiritual Education, Oxford Review of Education, 21: 1, 83-98.

Carr, D. (1991) Educating the Virtues, London: Routledge.

Carr, D., Haldane, J., Mclaughlin, T. and Pring, R. (1995) Return to the Crossroads: Maritain Fifty Years On, British Journal of Educational Studies, 43: 2, 162-178.

Cessario, R. (2005) A Short History of Thomism, Washington, DC: Catholic University of America.

Cessario, R. (2001) Introduction to Moral Theology, Washington, DC: Catholic University of America.

Chandler, D. (ed.) (2016) The Holy Spirit and Christian Formation, London: Palgrave Macmillan.

Chesterton, G. K. (1933) St. Thomas Aquinas, London: Hodder and Stoughton.

Chesterton, G. K. (1908) Orthodoxy, London: Hutchinson.

Collicutt, J. (2019) The Psychology of Christian Character Formation, London: SCM Press.

Congregation for Catholic Education (2014) Educating Today and Tomorrow: A Renewing Passion, Rome: Libreria Editrice Vaticana.

Congregation for Catholic Education (2007) Educating Together in Catholic Schools, Rome: Libreria Editrice Vaticana.

Congregation for Catholic Education (1997) The Catholic School on the Threshold of the Third Millennium, Rome: Libreria Editrice Vaticana.

Congregation for Catholic Education (1977) The Catholic School, Rome: Libreria Editrice Vaticana.

Conway, P. H. (1960) Principles of Education: A Thomistic Approach, Washington, DC: Thomist Press.

Cooper, J. M. (1986) Reason and Human Good in Aristotle, Cambridge, MA: Harvard University Press.

Coutier, D. and Mattison, W. C. (2014) The Resurgence of Virtue in Recent Moral Theology, Journal of Moral Theology, 3: 1, 228-259.

Crowe, M. B. (1981) Thomism and Today's Crisis in Moral Values, in Brezik, V. B. (ed.) One Hundred Years of Thomism, Houston, TX: University of St. Thomas Centre for Thomistic Studies.

Crysdale, C. S. W. (2002) Heritage and Discovery: A Framework for Moral Theology, Theological Studies, 63: 559-578.

Curren, C. E. (2005) The Moral Theology of John Paul II, Washington, DC: Georgetown University Press.

Daly, G. (1980) Transcendence and Immanence: A Study in Catholic Modernism and Integralism, Oxford: Clarendon Press.

Damon, W. (2009) The Paths to Purpose, New York: Simon and Schuster.

Darnell, C., Gulliford, L., Kristjánsson, K. and Panos, P. (2019) Phronesis and the Knowledge Action Gap in Moral Psychology and Moral Education: A New Synthesis? Human Development, 62: 3, 101-129.

Davies, B. and Kucharski, P. (2016) The McCabe Reader, London: Bloomsbury.

Dawkins, R. (2006) The God Delusion, Boston, MA: Houghton Mifflin. 
Dearden, R. F. (1982) Philosophy of Education 1952-1982, British Journal of Educational Studies, 30: 1, 57-71.

Donahue, J. (1990) Jesuit Education and the Cultivation of Virtue, in O'Brien, J. W. (ed.) Jesuit Education and the Cultivation of Virtues, Washington, DC: Georgetown University Press.

Donlon, T. C. (1952) Theology and Education, Dubuque, IA: William Brown Company.

Doren, van M. (1943) Liberal Education, New York: Henry Holt.

Doyle, D. M. (2007) Thomas Aquinas: Integrating Faith and Reason in the Catholic School, Catholic Education: A Journal of Inquiry and Practice, 10: 3, 343-356.

Drayton, N. (2014) The Case for Character: Looking at Character from a Biblical Perspective, Birmingham, AL: Cornerstone Books.

D'Souza, M. O. (2016) A Catholic Philosophy of Education: The Church and Two Philosophers, Toronto: McGill-Queen's University Press.

Dufault, L. (1946) The Aristotelian-Thomist Concept of Education, The New Scholasticism, 30: 3, 239-257.

Dykstra, C. (2003) Reconceiving Practice in Theological Inquiry and Education, in Murphy, N., Kallenberg, B. J. and Nation, M. T. (eds.) Virtues and Practices in the Christian Tradition: Christian Ethics after MacIntyre, Notre Dame, IN: Notre Dame University Press.

Eagers, J. (2011) Understanding Aquinas in the Contemporary Catholic Virtue-Ethics: Comparison of Servais Pinckaers OP and James Keenan SJ, Angelicum, 88: 4, 941-964.

Ehrman, B. D. (2018) The Triumph of Christianity, New York: Simon and Schuster.

Elias, J. L. (1999) Whatever Happened to Catholic Philosophy of Education, Religious Education, 94: 1, 92-110.

Elias, J. L. and Nolan, L. C. (2009) Educators in the Catholic Intellectual Tradition, Fairfield: Sacred Heart University Press.

Erb, F. (2004) Models of Thomistic Studies in Contemporary North American Higher Education, Verbum Analecta Neolatina, VI: 2, 461-482.

Farley, B. W. (1995) In Praise of Virtue: An Exploration of the Biblical Virtues in a Christian Context, Grand Rapids, MI: Eerdmans.

Fitzpatrick, E. A. (1953) Philosophy of Education, Milwaukee, WI: Bruce.

Flanagan, O. (1991) Varieties of Moral Personality: Ethics and Psychological Realism, Cambridge, MA: Harvard University.

Flannery, K. L. (2013) Action and Character According to Aristotle: The Logic of the Moral Life, Washington, DC: Catholic University of America Press.

Gaine, S. (2015) Aristotle's Philosophy in Aquinas's Theology of Grace, in Emery, G. and Levering, M. (eds.) Aristotle in Aquinas's Theology, Oxford: Oxford University Press.

Garrison, R. (1993) Redemptive Almsgiving in Early Christianity, London: Bloomsbury.

Garstin, L. H. (1949) Neo-Scholasticism in High School Education, The Educational Forum, 13: 3, 359-365.

Gilson, E. (1953) The Eminence of Teaching, Lecture given at St. Joseph's College for Women, West Hartford CT, 14 April 1953.

Gilson, J. F. (1953) Christian Character, Religious Education, 49: 4, 270-273.

Gleason, J. R. (1937) A Study of the Content of the Curriculum in High School Religion, $\mathrm{PhD}$, Chicago: Loyola University.

Golob, S. and Timmermann, J. (eds.) (2017) The Cambridge History of Moral Philosophy, Cambridge: Cambridge University Press.

Goodrich, R. M. (1958) Neo-Thomism and Education, British Journal of Educational Studies, 7: 1, 27-35. 
Grande, S. (2010) TEACHING BOLDLY! Letters to Teachers about Contemporary Issues in Education, Counterpoints, 356: 199-207.

Grobien, G. A. (2019) Christian Character Formation, Oxford: Oxford University Press.

Groome, T. H. (2018) Traces that Remain: From Life to Faith to Life, Religious Education, 113: 2, 147-155.

Groome, T. H. (1996) What Makes a Catholic School? In McLaughlin, T., O'Keefe, J. and O'Keefe, B. (eds.) The Contemporary Catholic School: Context, Identity and Diversity, London: Falmer Press.

Guinness, O. (2000) When No One Sees: The Importance of Character in an Age of Image, Colorado Springs, CO: NavPress.

Gula, R. M. (2003) The Call to Holiness, New York: Paulist Press.

Gula, R. M. (1989) Reason Informed by Faith: Foundations of Catholic Morality, New York: Paulist Press.

Gunn, D. (2018) Teaching for Cosmopolis: Bernard Lonergan's Hopeful Vision for Education in a Globalized World, Religious Education, 113: 1, 26-37.

Gutek, G. L. (2005) Jacques Maritain and John Dewey on Education: A Reconsideration, Educational Horizons, 83: 4, 247-263.

Gutek, G. L. (1997) Historical and Philosophical Foundations of Education: A Biographical Introduction, Upper Saddle River, NJ: Merril.

Guzie, T. W. (1960a) St. Thomas and Learning Theory: A Bibliographical Survey, The New Scholasticism, 34: 3, 275-296.

Guzie, T. W. (1960b) The Analogy of Learning: An Essay Toward Thomistic Psychology of Learning, New York: Sheed and Ward.

Hadot, P. (1995) Philosophy as a Way of Life, Oxford: Blackwell.

Haldane, J. (1989) Metaphysics in the Philosophy of Education, Journal of the Philosophy of Education, 23: 2, 171-183.

Hancock, C. (2005) Recovering a Catholic Philosophy of Elementary Education, Mount Pocono, PA: Newman House Press.

Harak, G. S. (1993) Virtuous Passions: the formation of Christian character, Eugene, OR: Wipf and Stock.

Harrington, D. and Keenan, J. (2010) Paul and Virtue Ethics, New York: Roman and Littlefield.

Harrington, D. and Keenan, J. (2002) Jesus and Virtue Ethics, New York: Roman and Littlefield.

Hauerwas, S. (2010) A Theological Memoir Hannah's Child, London: SCM Press.

Hauerwas, S. (1997) Christians Among the Virtues: Theological Conversations with Ancient and Modern Ethics, Notre Dame, IN: Notre Dame University Press.

Hauerwas, D. (1986) Vision and Virtues: Essays in Christian Ethical Reflection, Notre Dame, IN: Notre Dame University Press.

Hauerwas, S. (1983) The Peaceable Kingdom: A Primer in Christian Ethics, Notre Dame, IN: Notre Dame University Press.

Hauerwas, S. (1981) A Community of Character: Towards a Constructive Christian Social Ethic, Notre Dame, IN: Notre Dame University Press.

Hauerwas, S. ([1975] 1995) Character and the Christian Life, Notre Dame, IN: Notre Dame University Press.

Hauerwas, S. and Wells, S. (2011) The Blackwell Companion to Christian Ethics, Oxford: Wiley-Blackwell. 
Herdt, J. (2008) Putting on Virtue: The Legacy of the Splendid Vices, Chicago, IL: Chicago University Press.

Herman, G. (2006) Morality and Behaviour in Democratic Athens, Cambridge: Cambridge University Press.

Heynickx, R. and Symons, S. (2018) So What's New About Scholasticism: How Neo-Thomism Helped Shape the Twentieth Century, Berlin: Walter de Gruyter.

Hirst, P. (1976) Religious Beliefs and Educational Principles, Learning for Living, 5: 155-157.

Hoffman, T., Muller, J. and Perkams, M. (eds.) (2013) Aquinas and the Nichomachean Ethics, Cambridge: Cambridge University Press.

Holder, A. G. (1992) Saint Basil the Great on Secular Education and Christian Virtue, Religious Education, 87: 3, 395-415.

Hooft, S. Van, (2006) Understanding Virtue Ethics, Chesham, Bucks: Acumen.

Hughes, G. H. (1978) Authority in Morals: An Essay in Christian Ethics, Washington, DC: Georgetown University Press.

Hull, E. (1910) The Formation of Character, St. Louis, MO: B. Herder.

Inglis, J. (2002) On Aquinas, Belmont, CA: Wadsworth.

International Theological Commission (2009) In Search of a Universal Ethic: A New Look at Natural Law. Available at: https://www.vatican.va/roman_curia/congrega tions/cfaith/cti_documents/rc_con_cfaith_doc_20090520_legge-naturale_en.html

Jeeves, M. (2011) Rethinking Human Nature, Grand Rapids, MI: Eerdmans.

Jensen, S. J. (2013) Living the Good Life: Beginners Thomistic Ethics, Washington, DC: Catholic University of America Press.

Johnson, R. (2013) Rational Morality: A Science of Right and Wrong, London: Dangerous Little Books.

Jones, B. (2015) 'Securing the Rational Foundations of Human Living'. The Pedagogical Nature of Human Law in St. Thomas Aquinas, New Blackfriars, 96: 602-620.

Jubilee Centre for Character and Virtues (2013, 2015, 2017) Framework for Character Education in Schools, Birmingham: University of Birmingham.

Keenan, J. (2009) Fundamental Moral Theology: Tradition, Theological Studies, 70: 140-158.

Keenan, J. (2004a) Moral Wisdom: Lessons and Texts from the Catholic Tradition, New York: Rowman and Littlefield.

Keenan, J. (2004b) Notes on Moral Theology: Fundamental Moral Theology at the Beginning of the New Millennium: Looking Back, Looking Forward, Theological Studies, 65: 119-140.

Keenan, J. (1995) Virtues in the Ethics of Thomas Aquinas, Theological Studies, 56: 709-729.

Kenny, A. (1999) Aquinas on Aristotelian Happiness, in MacDonald, S. and Stump, E. (eds.) Aquinas's Moral Theory, Ithaca, NY: Cornell University Press, 15-27.

Kenny, A. (1998) An Illustrated Brief History of Western Philosophy, Oxford: Blackwell.

Kerr, F. (2002) After Aquinas: Revival Versions of Thomism, Oxford: Blackwell.

Kilpatrick, W. (1993) Why Johnny Can't Tell Right from Wrong: Moral Illiteracy and the Case for Character Education, New York: Simon and Schuster.

Kohlberg, L. (1981) The Philosophy of Moral Development, New York: Harper and Row.

Kotva, J. J. (1996) The Christian Case for Virtue Ethics, Washington, DC: Georgetown University Press.

Kreeft, P. (1992) Back to Virtue: Traditional Moral Wisdom for Modern Moral Confusion, San Francisco, CA: Ignatius Press.

Kristjánsson, K. (2020) Flourishing as the Aim of Education: A Neo-Aristotelian View, Abingdon: Routledge. 
Kristjansson, K. (2014) There is Something About Aristotle: The Pros and Cons of Aristotelianism in Contemporary Moral Education, Journal of Philosophy of Education, 48: 1, 48-68.

Lacy, T. (2014) Intellectum Quaerens Fides: Mortimer J. Adler's Journey of Mind and Heart, US Catholic Historian, 32: 2, 91-116.

Lacy, T. (2013) The Dream of a Democratic Culture: Mortimer J. Adler and the Great Books Idea, New York: Palgrave Macmillan.

Lawler, M. G. and Salzman, T. A. (2013) Virtue Ethics: Natural and Christian, Theological Studies, 72: 442-473.

Lawler, M. G. and Salzman, T. A. (2010) Human Experience and Catholic Moral Theology, Irish Theological Quarterly, 76: 1, 1-22.

Lewis, C. S. (2001) Screwtape Letters, New York: Harper Collins.

Lewis, C. S. (1989) Letters to Don Giovanni Calabria, London: Harper Collins.

Lewis, C. S. (1942) Mere Christianity, London: Collins.

Lickona, T. (1994) Raising Good Children, New York: Bantam Books.

Lickona, T. (1992) Educating for Character: How Our Schools Can Teach Respect and Responsibility, New York: Bantam Books.

Lickona, T., Schaps, E. and Lewis, C. (2007) CEP's Eleven Principles of Effective Character Education, Washington, DC: Character Education Partnership.

Lischka, C. (1926) National Catholic Educational Association Bulletin, 4 (August), 22-23.

Lonergan, B. (1990) Understanding and being: Collected works of Bernard Lonergan, vol. 5, Toronto: University of Toronto Press.

Lonergan, B. J. F. (1988) Topics in Education: Collected Works of Bernard Lonergan, vol. 10, Toronto: University of Toronto Press.

Lonergan, B. J. F. ([1974] 1996) The Transition from a Classicist-World-View to Historical-Mindedness, in Ryan, W. F. R. and Tyrell, B. J. (eds.) A Second Collection, Philadelphia, PA: The Westminster Press, (1996) edited version published by Toronto University Press.

Lonergan, B. J. F. (1972) Method in Theology, New York: Herder and Herder.

McCabe, H. (2005) The Good Life: Ethics and the Pursuit of Happiness, New York: Continuum.

McCool, G. (1996) The Neo-Thomist, Milwaukee, WI: Marquette University Press.

McCormick, R. (1989) Moral Theology 1940-1989: An Overview, Theological Studies, 503-24.

McCormick, R. (1968) The New Morality, America, 15 June, 769-772.

McDonough, K. (1994) The Importance of Examples for Moral Education: An Aristotelian Perspective, Studies in Philosophy and Education, 14: 77-103.

MacInerny, R. (1997) Ethica Thomistica: The Moral Philosophy of Thomas Aquinas, Washington, DC: Catholic University of America.

McInerny, R. (1993) The Question of Christian Ethics, Washington, DC: Catholic University of America Press.

McInerny, R. (1969) Thomism in an Age of Renewal, Notre Dame, IN: University of Notre Dame Press.

MacIntyre, A. (1990) Three Rival Versions of Moral Enquiry. London: Bloomsbury.

MacIntyre, A. ([1988] 1996: 2nd edn) Whose Justice? - Which Rationality, London: Bloomsbury.

MacIntyre, A. (1987) The Idea of an Educated Public, in Hayden, G. (ed.) Education and Values, London: University of London. 
MacIntyre, A. (1981) After Virtue: A Study in Moral Theory, Notre Dame, IN: Notre Dame University Press.

MacIntyre, A. (1964) Against Utilitarianism, in Hollis, T. H. B. (ed.) Aims of Education: The Philosophic Approach, Manchester: Manchester University Press.

McLaughlin, T. H. (1996) The Distinctiveness of Catholic Education, in McLaughlin, T. H., O'Keefe, J. and O'Keefe, B. (eds.) The Contemporary Catholic School: Context, Identity and Diversity, London: Falmer Press.

Maritain, J. (1968) Humanisme intégral: Integral Humanism: Temporal and Spiritual Problems of the New Christendom (J. W. Evans, trans.), New York: Charles Scribner's Sons.

Maritain, J. (1962) The Education of Man, Notre Dame, IN: University of Notre Dame Press. Maritain, J. (1961) On the Use of Philosophy, Princeton, NJ: Princeton University Press.

Maritain, J. (1955) Thomist Views on Education, in Henry, N. B. (ed.), Modern Philosophies and Education: The Fifty-fourth Yearbook of the National Society for the Study of Education, Part 1, Chicago, IL: The University of Chicago Press.

Maritain, J. (1951) Man and the State. Chicago, IL: University of Chicago Press.

Maritain, J. (1943) Education at the Crossroads, New Haven, CT: Yale University Press.

Marrou, H. (1956) A History of Education in Antiquity, London: Sheed and Ward.

Mattison, W. C. (2008) Introducing Moral Theology: True Happiness and the Virtues, Grand Rapids, MI: Brazos Press.

Mayer, M. H. (1929) The Philosophy of Teaching of St. Thomas Aquinas: Marquette Monographs in Education, Milwaukee, WI: Bruce.

Meilaender, G. C. (1984) The Theory and Practice of Virtue, Notre Dame, IN: Notre Dame University Press.

Meilaender, G. C. (1978) The Taste for the Other: The Social and Ethical Thought of C. S. Lewis, Grand Rapids, MI: Eerdmans.

Mill, J. S. (1981) Autobiography, in Robson, J. M. and Stillinger, J. (eds.) Collected Works of John Stuart Mill, vol. 1, Toronto: University of Toronto Press, 137, 139.

Miller, C. B. (2014) Character and Moral Psychology, New York: Oxford University Press. Miller, J. (2012) The Reception of Aristotle's Ethics, Cambridge: Cambridge University Press.

Misiak, H. and Staudt, V. M. (1954) Catholics in Psychology: A Historical Survey, New York: McGraw Hill.

Modero, C. (2015) The Theological Dynamics of Paulo Freire's Educational Theory, International Studies in Catholic Education, 7: 1, 122-138.

Mooney, T. B. and Nowacki, M. (2011) Understanding Teaching and Learning: Classic Texts on Education, Exeter: Imprint Academic.

Moser, A. and Leers, B. (1990) Moral Theology: Dead Ends and Ways Forward, Maryknoll: Orbis Books.

Murdoch, I. (1966) Vision and Choice in Morality, in Ramsey, I. (ed.) Christian Ethics and Contemporary Philosophy, New York: Macmillan.

Murphy, N., Kallenberg, B. J. and Nation, M. T. (2003) Virtues and Practices in the Christian Tradition: Christian Ethics After MacIntyre, Notre Dame, IN: Notre Dame University Press.

Nabers, D. (2005) The Case for Character: Looking at Character from a Biblical Tradition, Birmingham, AL: Alliance.

Newell, E. J. (2006) Education Has Nothing to do with Theology, Eugene, OR: Pickwick Publishers/Princeton Theological Monographs Series.

Newman, J. H. (1996) The Idea of a University, Turner, F. M. (ed.), Newhaven, CT: Yale University Press. 
Norman, E. (1985) Roman Catholicism in England, Oxford: Oxford University Press.

Northrop, F. S. C. (1952) The Meeting of East and West, New York: Macmillan.

Nussbaum, M. C. (2001) The Fragility of Goodness, Cambridge: Cambridge University Press.

O'Meara, T. F. (1997) Virtues in the Theology of Thomas Aquinas, Theological Studies, 58: 254-285.

Oxenham, M. (2019) Character and Virtue in Theological Education, Cumbria: Langham.

Ozolins, J. J. (2013) Aquinas and His Understanding of Teaching and Learning, in Mooney, T. B. and Nowacki, M. R. (eds.) Aquinas, Education and the East, New York: Springer.

Palmer, M. (2016) Ethical Formation: The Theological Virtues, in Chandler, D. J. (ed.) The Holy Spirit and Christian Formation, London/New York: Palgrave Macmillan.

Papal Teachings: Education (1960) Papal Teachings: Education. Selected and Arranged by the Monks of Solesmes, Boston, MA: St. Paul Editions.

Pelser, A. C. and Cleveland, W. S. (eds.) (2021) Faith \& Virtue Formation: Christian Philosophy in Aid of Becoming Good, New York: Oxford University Press.

Pereira, J. (2002) Thomism and the Magisterium: From Aeterni Patris to Veritatis Splendor, LOGOS: A Journal of Catholic Thought and Culture, 5: 3, 147-183.

Peters, R. S. (1981) Moral Development and Moral Education, London: George Allen and Unwin.

Peterson, C. and Seligman, M. (2004) Character Strengths and Virtues: A Handbook and Classification, New York: Oxford University Press.

Piderit, J. J. and Morey, M. (eds.) (2012) Teaching and Tradition: Catholic Themes in Academic Disciplines, Oxford: Oxford University Press.

Pieper, J. (1986) Faith, Hope and Love, San Francisco, CA: Ignatius Press.

Pieper, J. (1954) The Four Cardinal Virtues, Notre Dame, IN: Notre Dame University Press.

Pinckaers, S. (2005) Sources of the Ethics of St. Thomas, in Beckham, J. and Titus, C. S. (eds.) The Pinckaers Reader, Washington, DC: Catholic University of America Press.

Pinckaers, S. (2001) Morality: The Catholic View, South Bend, IN: St. Augustine's Press.

Pinckaers, S. (1998) The Pursuit of Happiness - God's Way: Living the Beatitudes, New York: Alba House.

Pinckaers, S. (1995) The Sources of Christian Ethics, London: Continuum.

Pope, S. (2014) Virtue and Theology, in Timpe, K. and Boyd, C. A. (eds.) Virtues and their Vices, Oxford: Oxford University Press.

Pope Benedict XVI (2010) The Virtues, Lindsey, J. (ed.), Huntington: Our Sunday Visitor Publications.

Pope Benedict XVI (2009) Caritas in Veritas (Charity in Truth), Rome: Libreria Editrice Vaticana.

Pope John Paul II (1998) Fides et Ratio (On the Relationship Between Faith and Reason), Encyclical, Rome: Libreria Editrice Vaticana.

Pope John Paul II (1993) Veritatis Splendor, Encyclical, Rome: Libreria Editrice Vaticana.

Pope Leo XIII (1879) Aeterni Patris (On the Restoration of Philosophy), in Acta Sanactae Sedis, Rome: Vaticana, vol. 12, 97-115.

Pope Pius XI (1929) Divini Illius Magistri (The Christian Education of Youth), Encyclical, Rome: Libreria Editrice Vaticana.

Porter, A. (2017) Jesuit Pupil Profile, London: Jesuit Institute.

Porter, J. (2005) Right Reason and the Love of God: The Parameters of Aquinas' Moral Theology, in van Nieuwenhove, R. and Wawrykow, J. (eds.) The Theology of Thomas Aquinas, Notre Dame, IN: University of Notre Dame Press, 167-191. 
Porter, J. (2001) Virtue Ethics, in Cambridge Companion to Christian Ethics, Cambridge: Cambridge University Press.

Porter, J. (1990) The Recovery of Virtue, Louisville, KY: Westminster.

Principe, W. (1994) St. Thomas Aquinas, in McBrien, R. (ed.) Encyclopaedia of Catholicism, San Francisco, CA: Harper Collins.

Pring, R. (2001) Education as a Moral Practice, Journal of Moral Education, 30: 2, 101-112.

Putnam, R. and Campbell, D. E. (2002) American Grace, New York: Simon and Schuster.

Rasmussen, J. D. (2012) Disciple of Christ: Education in Virtue Educators Guide, Ann Arbor, MI: Lumen Ecclesia Press.

Ratzinger, J. (1996) La via della fede (The Way of Faith), Milan: Ares.

Ravaisson, F. (2008) Of Habit (translated by C. Carlisle and M. Sinclaire), London: Continuum.

Redden, J. D. and Ryan, F. A. (1942) A Catholic Philosophy of Education, Milwaukee, WI: Bruce.

Rhodes, D. P. and Lysaught, M. T. (2020) Where Revolution? Which Future? The Legacy of Alasdair MacIntyre for a Radical Pedagogy of Virtue, Expositions, 14: 1, 97-125.

Rober, D. (2015) Engaging the Neo-Thomist Revival, Horizons, 42, 262-294.

Rose, M. (2015) The Liberal Arts and the Virtues: A Thomistic History, LOGOS: A Journal of Catholic Thought and Culture, 18: 2, 34-65.

Rowland, T. (2003) Culture and the Thomist Tradition: after Vatican II, London: Routledge.

Rugg, H. (1947) Foundations for American Education, New York: World Book Company.

Russell, D. C. (2013) Virtue Ethics, Happiness, and the Good Life, in Russell, D. C. (ed.) The Cambridge Companion to Virtue Ethics, Cambridge: Cambridge University Press.

Russell, R. (1992) Basic Writings of Bertrand Russell 1903-1959, London: Routledge.

Rutkowski, R. (1990) Edward August Fitzpatrick and Catholic Education 1924-1960, PhD thesis, Loyola University Chicago.

Sanford, J. J. (2015) Before Virtue: Assessing Contemporary Virtue Ethics, Washington, DC: Catholic University of America.

Schools Curriculum Foundation Document of the Diocese of Marquette (2014) Foundations Document for the Catholic School Curriculum of the Diocese of Marquette, March 2014. Approved by Bishop John Doerfler. Available at: https://www.dioce seofmarquette.org/catholicschoolsSelling, J. A. (2016) Reframing Catholic Theological Ethics, Oxford: Oxford University Press.

Selling, J. A. and Jans, J. (1994) The Splendour of Accuracy - An Examination of the Assertions Made in Veritatis Splendor, Grand Rapids, MI: William. B. Eerdmans.

Sertillanges, A. G. (1989) The Intellectual Life: Its Spirit, Conditions, and Methods, Washington DC: Catholic University of America.

Shanley, B. J. (2002) The Thomist Tradition, Boston, MA: Kluwer Academic Publishing.

Slavin, R. J. (1942) The Thomistic Concept of Education, in Brennan, R. E. (ed.) Essays on Thomism, Eugene, OR: Wipf and Stock.

Slavin, R. J. (1937) The Essential Features of the Philosophy of Education of Saint Thomas, Philosophy of Education, 15: 22-38.

Snow, N. (ed.) (2018) Oxford Handbook of Virtue, Oxford: Oxford University Press.

Soloveitchik, J. B. (2001) The Lonely Man of Faith, Jerusalem: Koren.

Sparr, A. (1990) Promote, Defend and Redeem, London: Greenwood Press.

Spohn, W. C. (1992) The Return of Virtue Ethics, Theological Studies, 53: 1, 60-75.

Stafford, J. (2019a) The Educationalization Process and the Roman Catholic Church in North America during the long Nineteenth Century, in Bruno-Jofre, R. (ed.) 
Educationalization and its Complexities: Religion, Politics and Technology, Toronto: University of Toronto Press.

Stafford, J. (2019b) Vatican II and Catholic Religious Secondary Education in Ontario: Changes within a North American Context, The Theory and History of Education Monograph Series vol. 2, Canada: Queens University.

Sternberg, R. J. (2002) Why Smart People Can Be so Stupid, New Haven, CT: Yale University Press.

Sullivan, E. (2021) Habit and Holiness, Washington, DC: Catholic University of America Press. Svenson, M. and Van Drunen, D. (2018) Aquinas among the Protestants, Oxford: Wiley Blackwell.

Talivaldis Ozolins, J. (2018) Education and the Pursuit of Wisdom: The Aims of Education Revisited, London: Routledge.

Taylor, A. E. (1920) Philosophy, in Marvin, F. S. (ed.) Recent Developments in European Thought, Oxford: Oxford University Press.

Taylor, C. (2007) A Secular Age, Cambridge, MA: Harvard University Press.

Taylor, C. (1991) The Ethics of Authenticity, Cambridge, MA: Harvard University Press.

Tigner, S. S. (2000) Cultivating Virtue, Journal of Education, 182: 2, 11-18.

Titus, C. S. (2012) Servais Pinckaers and the Renewal of Catholic Moral Theology, Journal of Moral Theology, 1: 1, 43-68.

Titus, C. S. (2008) Moral Development and Making All Things New in Christ, The Thomist, 72: 2, 233-258.

Topping, R. N. S. (2012) Happiness and Wisdom: Augustine's Early Theology of Education, Washington, DC: Catholic University of America.

Treier, D. J. (2006) Virtue and the Voice of God: Toward a Theology of Wisdom, Grand Rapids, MI: Eerdmans.

Vanier, J. (2001) Made for Happiness: Discovering the Meaning of Life with Aristotle, London: Darton Longman Todd.

Vatican Council II (1965) Declaration on Christian Education (Gravissimum Educationis). Declaration of the Second Vatican Council, 28 October 1965. Rome: Vatican City.

Veverka, F. B. (1993) Defining a Catholic Approach to Education in the US 19201950, Religious Education, 88: 4, 523-542.

Vitz, P. C., Nordling, W. J., and Titus, C. S. (eds.) (2020) A Catholic Christian MetaModel of the Person: Integration with Psychology and Mental Health Practice, Sterling, VA: Divine Mercy University Press.

Wadell, P. (2007) Happiness and the Christian Moral Life, New York: Rowman and Littlefield.

Walters, H., Arthur, J. and Gaine, S. (1999) Earthen Vessels: The Thomistic tradition in Education, Leominster: Gracewing.

Weil, S. (2009) Waiting for God, London: Harper Collins.

Wiele, van, J. (2007) Neo-Thomism and the Theology of Religion: A Case Study on Belgium and US Textbooks 1870-1920, Theological Studies, 68: 4, 780-807.

Willingham, D. T. (2007) Critical Thinking: Why Is It So Hard to Teach? American Educator, 31: 8-19.

Wilson, J. M. (2014) An Organ for a Frenchified Doctrine: Jacques Maritain and The Criterion's Neo-Thomism, in Lockerd, B. G. (ed.) T. S. Eliot and Christian Tradition, Lanham, MD: Fairleigh Dickenson University Press.

Wogaman, J. P. (2011) Christian Ethics: A Historical Introduction, Louisville, KT: Westminster John Knox Press. 
Wright, D. (2015) The Good Sense of Aristotelian Character Education, Jubilee Centre for Character and Virtues Conference, Oxford: Oriel College, 10 January 2015.

Wright, D. (2014) Character Education Secondary Curriculum, Jubilee Centre for Character and Virtues, Birmingham: University of Birmingham.

Wright, D., Morris, I. and Bawden, M. (2014) Character Education: A Taught Course for 11-16 Year Olds, Birmingham: University of Birmingham: Jubilee Centre for Character and Virtues.

Wright, J. C., Warren, M. T. and Snow, N. E. (2021) Understanding Virtue: Theory and Measurement, Oxford: Oxford University Press.

Wright, N. T. (2010) After You Believe: Why Christian Character Matters, New York: HarperOne.

Wynne, E. and Ryan, K. (1993) Reclaiming Our Schools: A Handbook in Teaching Character, Academics and Discipline, New York: Macmillan.

Young, de R. K., McCluskey, C. and Van Dyke, C. (2009) Aquinas Ethics: Metaphysical Foundation, Moral Theology and Theological Context, Notre Dame, IN: Notre Dame University Press.

Zagzebski, L. (1996) Virtues of the Mind: An Inquiry into the Nature of Virtue and the Ethical Foundations of Knowledge, New York: Cambridge University Press.

Zimmerman, T., Gentner, U. and Spermann, J. (2020) Humanism + Personality Formation on the Basis of Ignatian Pedagogy, Centre for Ignatian Pedagogy, German Province of the Society of Jesus.

Zybura, J. S. (1927) Present-day Thinkers and the New Scholasticism: An International Symposium, New York: Herder Books. 


\section{Index}

Page numbers in bold refer to tables.

absolute good, notion of 49 acquisition of wisdom 61

Adler, Mortimer 70-71; definition of education 96; Paideia Proposal: An Educational Manifesto (1982) 96

Aeterni Patris (On the Restoration of Philosophy) 63, 68

Agapistic ethics 20

almsgiving 119-120

America (Jesuit journal) 15

American Catholicism 67

anthropology, Christian understanding of see Christian anthropology

Aquinas, Thomas xi, xiv, 17, 29, 39, 41, 49, 67, 97, 106, 145; Aristotelianism of 31; on Augustine's view of the world 34; definition of education 2;

definition of mercy 11; De Magistro 73; Dominican Order 47; ethics in the Summa Theologiae 31, 34; moral theory of 44, 61, 75; philosophical ideas of $31-33$; stress on human reasoning 54; Summa Contra Gentiles 47; Summa Theologiae 31, 34, 47, 65; teaching on freedom 10; theological intention of 32 ; theology of grace 18 ; theory of education 2, 61, 62-66; understanding of teaching 101; understanding of virtue and habit 50 ; vision of $48-50$

arête xiv, 154

Aristotelian-Christian comparisons xv, 38-42

Aristotelian-Thomist perspective, on Christian moral tradition xiv, 35, 138

Aristotle xi, xiv, 29-30, 32, 35-38, 48, $60,106,154$; concept of good life 32 ; definition of virtue 37; departure from Christian thinking on character formation 40; ethical works of 47; Ethics 84, 103; ethics of character xii; ethics of happiness 103; eudaemonist virtue 32, 35; framework for moral character virtues 25 ; ideal of happiness 48 ; idea of teleology/human nature 41; ideas about human flourishing 41; pagan virtues of 48; philosophical ideas of 31-33; phronesis 127, 146; scheme of ethics 41 ; on value of human life on the basis of intellectual capacity 40; virtues to religious faith 32 ; vision of the virtuous person 29

art of living 48

attractiveness of goodness 85

Augustine 33-35, 49, 147; Confessions 99, 128; De Catechizandis Rudibus 98; definition of a virtue 33; idea of pagan virtues 34; rejection of determinism 33

Aurelius, Marcus 116-117; Meditations 116, 135-136; method to extend a liberal education 135; views on virtues as key to a good life 117

autonomous reasoning, development of 58

Baltimore Catechism 77

baptism 2, 32, 42, 110, 147

beatitude (eternal happiness): parts of 40 ; supernatural 51

Beck, Bishop 64

becoming who we are, process of 2

behavioural competencies 91

behaviourism, notion of 57,69 
Benedict XVI, Pope 20, 107, 114

Berkeley Graduate Theological Union 18

Bible 20, 25-26, 32, 34, 67, 104, 120

Biblical ethics 20

bigots 8,95

biological organisms, sexes of 42

Blanshard, Brand 77

Brooks, David 125

Bruce Publishing Company of Milwaukee 73

Brunner's 'Spiral Curriculum' 91

Cardinal Newman Society, United States 133

cardinal virtues 29-30, 32, 34, 49, 51-52, 84, 108, 118-119, 147-148, 151-152;

of charity 31 ; God's grace and 31; roles of 31; types of 118

Caritas in Veritate (2009) 114

Catechism of the Catholic Church, The (1994) 58, 76, 84, 108

Catechist's Manual (1907) 73

Catholic Church 2-3, 17, 57, 64, 72; authority of 20; cogent theory of human conduct 10; English and Scottish 65; mission in education 107; Roman 121

Catholic education: Cardinal Newman Society, United States 133; Catholic University of America 67; in character 103-110; child-orientated methods 76; concept of 18, 148; criticisms of the teaching methods in 76; distinctiveness of 109; within a dominant nonChristian culture 30; five wrongs in 70 ; friendship with God 107; goal of 25; higher education institutions 65 ; for holistic formation of persons 18 ; idealist and subjectivist philosophies of 77; idea of 'change' in 79; learning by doing 76; methods of 70; objectives of 70, 107; philosophy of $6,8,24,62,66,69-70$, 108, 141-143; process of building character 24; in public schools 70 ; religious education textbooks 74,76 ; role of Clement in 30; school curriculum 70; social teaching 71; theory and practice 70; virtue-based framework for 116; virtues of 109

Catholic faith 15, 67, 73, 109; American Catholicism and 67; character and virtues of 42 ; protection and adornment of 63; systematic defence of 68

Catholic identity, principles of 77, 133

Catholic moral teaching 11-12, 24; commandment of 17 ; critical challenges to 11-15; culture of moral individualism 12; guidelines of 14; Jesuit critics of traditional 15; in New Testament 27; by revisionist group 13; scrutiny and critical appraisal from Church 11; styles of moral reasoning 12 ; telos of 28 ; by traditionalists group 12; on virtuous living 18

Catholic moral theology 3, 5, 19, 44, 64

Catholic moral tradition 8; charge of indoctrination 14; Christian identity of 15; debates about 11; ethical 11

Catholic Philosophy of Education, $A$ (1942) 70

Catholic "philosophy of life" 67

Catholic sacramental imagination 145

Catholic School, The 107

Catholic School Journal 69

Catholic School on the Threshold of the Third Millennium, The (1997) 107

Catholic schools 98, 133; aim of 14; curriculum 14, 109; difference with non-Catholic institutions 65; educational courses in 65; ethos of 109; idea of 14; methods of instruction 106-107; religious education in 66; religious textbooks in 68, 74; teachers in 106-107; teaching rules 24, 109; virtues of 109

Catholic social teaching 71

Catholic teacher training 63

Catholic Universities 81; curriculum in 71; theology and philosophy in 66

Catholic University of America 67-68, 72 character: development of 29, 133; ethics xii, xvi, 1, 34; in moral life, notion of 3, 115; taught, caught and sought 87; theological vision of 48; types of 87; see also Christian character formation; virtues

character building: becoming what we are 140; Christian philosophy and theology of 39; within the context of a Christian anthropology 138; created in God's image 139-140; ethics of 38; goals of $7,86-87$; process of $28,30,96$; role of human agency in 39

character education: Aristotelian-inspired 91; Centre's approach to 90; Eleven 
Principles of Effective Character Education (2007) 85; essential elements of 85; framework of 85-88; Jubilee Centre for Character and Virtues 85, 95; language of 92 ; practicalities of 138 ; secular to Christian 95-98

character virtues: Christian thinking on 38 ; concept of 42; development of 29 ; in education 42; formation of 48,143 ; role in human flourishing 42

charity: and generosity 119; and hospitality, Christian virtues of 120

Chesterton, G. K. 10, 47, 66

Christian anthropology 2-3, 26, 59, 109, 139, 155; and character 42-45; character formation within the context of 138; formation of the person based on xii; tenets of 42

Christian assertions, types of 42, 139

Christian beliefs 5, 48, 116, 119-121

Christian casuistry 25

Christian character: notion of 140; schools of 144-146; teachers of 143-144; virtues $1, \mathbf{1 1 7}, 140$

Christian character formation xi-xiii, 43, 142; aim of 113, 151; believes and values of 2-6; building blocks of 147-148; Catholic and Protestant perspectives on 4; Christ-centred 144; critical challenges to Christian moral teaching 11-15; divine-human encounter as the source of 150; educational potential of xiii; ethics of xiv; fellowship 147; on forming and reforming the self 15; God of the Old Testament 4; growth in knowing 3; how should I live 6-7; language of 14; learning objectives for teaching 1 , 150-151; moral virtues of 5 ; natural virtues of 148; Neo-AristotelianThomist theory of xiii, $5,10,18,25$; notion of 5,14 ; as a pathway to union with God 151-152; philosophies and perspectives on xii, 1-2; presumption of unbelief 8-11; process of 2; proportionalism, theory of 15-21; resources for building 2; supernatural virtues for 149-150; teaching the whole person 144; theology and 7-8; theoretical framework for conceptualising 5

Christian community 2, 11, 20, 26, 30; authoritative role of 60; Christian schools as part of 144; expression of fellowship within 120; spiritual and theological dimensions of the person in 3; spiritual life of 27

Christian convictions 43

Christian discipleship 17, 133

Christian education see Catholic education

Christian ethicists xii

Christian ethics 15, 20, 41, 43-44, 50, 54, 105, 107

Christian ethos 144

Christian Europe 47

Christian faith xii, 43, 97, 144; fundamental beliefs of 104; Greek philosophy to understand 30; life of 136

Christian fellowship 2, 147

Christian heritage 48

Christian humility 119

Christian idea of being 150

Christian identity, of Catholics 15

Christian intellectual virtues 121-123

Christianised Aristotelianism 32

Christianity 1, 5-7, 24, 30, 37, 40; Christian virtues without a belief in 10 ; impact of Reformation on 10; Jesus's sermon as the "charter of the Christian life' 27; list of virtues 84; love of Christ 28 ; moral teachings of 10 ; scripture and character in 26-28

Christian life 105; in community 131; pattern of 110; as the pursuit of Godly virtues 27

Christian morality/moral 5-6, 15, 26, 113,142 ; activity, foundation of 108 , 148; framework 10; life 4, 104, 118, 143, 148, 149, 155, 159; theology 98; virtues 123-124

Christian pedagogy xvi, 98-103

Christian performance virtues 124-126

Christian philosophy, of education 6, 8, 24, 62, 66, 69-70, 108, 141-143

Christian revelation xii, 49, 54, 71

Christian schools see Catholic schools

Christian teachers: of character 143-144; relationship with students 116 ; teaching the whole person 144; training colleges in UK 65

Christian theism 5

Christian theological frameworks 100, 142

Christian virtues: development of 24; education, in practice 129-136, 140; without a belief in Christianity 10 
Christ, Jesus xiii, 1, 11, 14, 43, 47-48, 110, 134; Christian claims about 142; God's self-disclosure in 34; implications of faith in 115; incarnation of 121; knowledge of 121; passion of 145 ; sacrifice on the cross 121; story of 146 ; teachings of 26, 63; as the ultimate teacher 143-144

Church 1, 9; Catholic Church 2-3, 10 , 17; fundamental teachings of 11 ; hierarchy 65; imposition of Thomism on 74; monolithic philosophical system 74; moral teachings 34, 60; scrutiny of Catholic moral teaching 11; teachings on education 65,67

civic democracy xi

civic virtues 87, 119, 123, 124, 126, 148

classical education: idea of 'fixing the kids' 135; purpose of 134

Clement of Alexandria: on how to live as a Christian 30; Pedagogus, The 98; role in Christian education 30

codes of conduct 154

Commentary on the Sentences 101 common good, promotion of 17-18, 24, $31,34,39,49,53,60,62,87,108$, 124, 130, 146-147, 151, 158

common-sense virtue ethics 95 communal formation, of individual identity 34

communal well-being 29

communities of practice 100, 102

community organisations 87

Compendium of the Social Doctrines of the Church (2004) 108

Congregation for the Clergy 73

connatural knowledge 123

conscience and freedom, notion of 56-62

constantia (perseverance) 84

consumer goods, transfer of 24

co-operative learning 95

cosmopolis 79

Cosmos, perception of 29

counsel, virtues of 149

critical thinking 14, 67, 88, 117, 129, 141

cult offerings 26

cultural transmission 8

curriculum: alternative model 91;

Brunner's 'Spiral Curriculum' 91;

of Catholic schooling 109; Christian

curriculum 132; experiential model 91; school curriculum 91 'dark night of the soul' 122

Dawkins, Richard 4

decision-making 41, 44, 53, 57, 128, 132; autonomous 94; complexity of 11,26 ; moral decisions 25, 27-28, 37, 85, 152; moral dilemmas in 85

Declaration on Christian Education (Second Vatican Council) 107

De Magistro 73, 100

determinism 40; Augustine's rejection of 33; theories of 57

developing virtue, strategies for 135

Dewey, John 71, 75

Diocesan Catechetical Offices 73

discernment, notion of 131

Disciple of Christ, Education in Virtue, The 132

discipleship and virtue, themes of 13

discipleship, life of 107

divine commands 11,20

divine-human encounter 150

divine spark 135

divine things, knowledge of 149

Divini Illius Magistri (On the Christian

Education of Youth) 63, 107

Dominican Order 47, 63

ecclesial communion 102

Educating Together in Catholic Schools 108 education: Adler's definition of 96; based on Catholic theological doctrine 64; Catholic moral teaching 11; Catholic philosophy of 64,108 ; changing Thomism for 78-81; character virtues in 42; of children 62; Christian philosophy of $6,8,24,38,62,66,69-70$, 108; Church's mission in 107; Church teachings on 65; courses, in Catholic colleges 65; definition of 2 ; educational unity 70 ; encyclicals and papal teachings on 65; English education policy 89; fragmentation of 108; goals of 25 , 48; human flourishing and 38; instrumental-orientated 23; learning approaches 75 ; liberal 101; as lifelong process of learning 7; Lonergan's vision of 79, 81; of men as men 71; moral education 100; neo-Aristotelian educational philosophy 90; neo-Thomist integral realism for 72; philosophies of 1-2, 26, 104; public education 10; in public schools 70; self-transcendence 79; 
theology of 7-8; training in skills needed to function in society 30 ; utilitarian philosophy of 23; see also Catholic education; character education; Christian character formation; Thomism in education

Education Reform Act (1988) 89

egalitarian sentiments 142

Eleos (compassion) 40

Eleven Principles of Effective Character Education 85

Eliot, T. S. 66

end of life, with God 33-34, 50

'ends justifies the means' argument 15

English education policy 89

Enlightenment xiv, 84

epiphanic awakenings 40

epistemological realism 138

ethics/ethical: goal of 29; life, within a

Christian theology 8; maturity 92;

methodologies, plurality of 9 ; reasoning

15 ; scandals 85 ; self, empowerment of

94; thinking 30, 52, 155

eudaimonia 35-36, 39, 156

eudemonia 39, 154

eulogy virtues 125

European history pro-social behaviour, phases of 119

Eusebius of Caesarea 29

exclusive truth, notion of 14

faith: Christian virtue of 40, 149; morality 8 ; theological virtues of 52,118

faithful Christian living 1, 138

false pride 41

fathers and characters, in Christianity 28-31, 42

fear: and legalism, morality of 14 ; of the Lord 52, 149

firmitas (tenacity) 84

Fitzpatrick, Edward 68-69, 73, 75; on five wrongs in the Catholic education 70; Philosophy of Education (1953) 70

'fixing the kids', idea of 135

Flanagan, Owen 57-58

Formation in an Age of Uncertainty (2019) 78

fortitude, virtue of 118, 148, 149

Framework for Character Education in Schools, $A$ (2017) xvi, 86, 89

Francis, Pope 11, 15, 70, 115 freedom: abuse of 58; Christian definition of 58-59; concepts of 59; definition of 59; for excellence 59-60; of indifference 59; self-centred 59; Thomas's teaching on 10

free will 5, 33, 41, 53, 57, 59, 69, 96, $139,146,154$

Freire, Paulo 99-100

generosity and charity, virtues of 27 , $119-120$

God 58, 62, 78; causes of alienation from 43; character formation as a pathway to union with 151-152; commands of 20; dealings with humanity 140; design and purpose for us 104; divine nature of 139; end of life with 33-34; friendship with 24 ; glory of 27; goodness of 27; grace of 33, 43, 48, 51, 53, 60, 104, 132, 150; idea of 4; image and likeness of 139-140; knowing-with 56; knowledge of 150 ; life in co-operation with 49; mercy 11 ; moral laws as a guide for our lives 33; of Old Testament 4; relationship with 43; salvation 110; self-disclosure in Christ 34 ; supernatural destiny of communion with 42,52 ; will of 28,33 ; wisdom in ordinary practical life 128

'good' behaviour 97

good judgement, practice of 62,143

good life: Aristotle's conception of 32 ,

154; concept of xiv, 2, 6, 39; idea of an objectively identifiable 14 ; visions of 43 good living 62

goodness, desire for 159

good practice, biblical patterns of 48

good sense 88, 90-91, 126-128, 131, 143,146

good versus evil, myth of 19

Gospel 96, 107

Gospel values 76, 142

grace, theology of 18, 29

Greco-Roman and early Christianity, division between 121

Greco-Roman society 120

Groome, Thomas 78, 102

habits: development of 132; forming 36 habitus 36, 51

Hauerwas, Stanley 3, 9, 15, 26, 41, 57, 85, 104, 106, 109, 113, 157

Hebrew Scriptures 30 
Hennessy, Katherine 18

Holy Spirit 1, 28, 52, 110, 115, 124, 127, 132, 142-143, 149-150

honestas (respectability) 84

hope, virtue of 149

hospitals, development of 120

'how should I live?', notion of 6-7, 139

human beings/human: ability to think rationally 38 ; act, principle of 51 ; awakening, notion of 2 ; communities, hierarchy of 60 ; conduct 7,10 ; consciousness 80 ; destiny 48 ; development 80, 114-115, 134; dignity 3, 17, 116, 158; formation of 107 ; fulfilment, Christian theory of $37,49,105,139$; happiness 53, 105; intellectual virtues of 38 ; intelligence 38 ; morality, principles for 21; as social creatures xii; types of 42; see also integral humanism/ human development

human flourishing: Aristotle's ideas about 41, 154; character virtues role in 42; notion of 8, 38-39, 157; without assistance 90

Humani Generis (1950) 70

humanizing pedagogy 100

human life: nature and purpose of 24; teleological view of 103; value on the basis of intellectual capacity 40

human nature: Aristotelian-Thomist understanding of 138; idea of 28, 155; vision of 70

human reason 110, 113, 141-142; capacity of 105 ; cultivation of 72 ; power of 70

Image of God (imago dei) 2, 11, 33, 42, $69,139,152,155$

individualistic self-development 114

indoctrination, charge of 14

industria (hard work) 84

In Search of a Universal Ethic 41

instinctive moral knowledge 123

instrumental intelligence 127

integral humanism/human development 114

integral realism, Thomist principles of 72

integrated education 114-115

intellectual conformity 122

intellectual virtues $14,37-38,61,87,88$, $118,122-124,129,148,154$

intelligent action, practice of 62 interior illumination 124 intersectionality, matrices of 19

intimations of immortality 101

Jesuit critics, of traditional Catholic teaching 15

Jesuit Departments of Education 17

Jesuit education 130; about forming the heart and the character of the student 132; characteristics of 131

Jesuit Pupil Profile 131

Jews 118

John Paul II, Pope 11-12; moral teaching and theology of 12; Veritatis Splendor (1993) 11-12, 16, 58, 74, 107

Jones, Greg 104

joy, sense of 51

Jubilee Centre for Character and Virtues 85, 115, 119; Framework for Character Education in Schools, A (2017) 86; virtue-based framework for Christian education 116

Judeo-Christian tradition: divine-law 19; virtues of 10

justice, notion of 40, 118, 148

Kantianism, rise of 84

Kenny, Anthony 31, 39

Kilpatrick, William 85

Kingdom of God 73, 84

knowledge: acquisition of 62, 100; of God 127, 150; virtue of 149

Kohlberg, L.: on development of moral reasoning 58; idea of the morally excellent person 58 ; moral reasoning model 57

learning: about life, revitalisation of 79 ; by doing 76; life-long process of 101, 142; process of 7; self-governed 135

Lee, James Michael 78

Leo XIII, Pope 63, 67-68

Leuven Neo-Thomist School 68

Lewis, C. S. 14, 96, 115, 122, 145

liberal education $71,101,129,134-135$

Lickona, Thomas 85, 97

life: purpose of 154; of relationship 40; story 45; of virtue 29, 34, 48, 91, 133

Lischka, Charles 68, 72

lived experience 9

Louis, Bernard 73

love: of neighbour 17, 40, 120, 149, 152; virtue of 149 
MacIntyre, Alasdair xiv, 19-20, 100; After Virtue (1981) 19-20; on contrast between man-as-he-happens-to-be and man-as-he-could-be-if-he-realizedhis-essential-nature 35; prospect for renewal of the public moral life 19; Three Versions (1990) 20; Whose Justice (1988) 20

malaises of modernity xiv

Maritain, Jacques 2, 63, 71-72, 101, 114, 155

Marquette University Institute for Catechetical Instruction 69

Matthew's Gospel 27

Mayer, Mary Helen 73

McCabe OP, Herbert 126

McCormack, Richard 15-16

Mclnerny, Ralph 31

mercy: definition of 11; God's mercy 11

Mere Christianity 115

metaphysical knowledge 40

meta-virtue of phronesis 40

Miller, Christian 135

modern culture, agenda of 5, 13, 138

monolithic philosophical system 70, 74

morality/moral: behaviour, theories of 29 , 35 ; character, deepening of 1,123 ; decision-making 25, 27-28, 37, 44, 57, 85, 152; development 36; dilemmas 23, 85, 92, 95, 132; education 58, 100, 129; exemplar, concept of 20,30, 37, 102, 144; formation, problems in 53-55; goodness, knowledge of 28 , 145 ; heritage of society 85 ; individualism, culture of 12 ; judgement 15,20 , 91, 103, 105, 124, 156; knowledge, instinctive 20, 123; luck 39; nihilism 5; pedagogy, development of 60,92 ; philosophy (philosophical ethics) xiv, 4, 7, 32; theology 3, 7, 11-13, 15, 17-19, $36,56-57,64,75,98,103,115$; theory of 59 ; training and habituation 61 ; virtue education, Catholic understandings of 6 ; virtue-orientated 44; virtues 1, 5-6, 10, 20, 27, 44, 49-50, $52-53,61,64,80,84,87,105,108$, 123-124

moral life 15, 30, 41, 50; human actions in 40 ; living, dynamics of 3,10 ; notion of xiv, $3-4,10$; restoration of 20 ; social role and ethos in 20; social sciences and philosophy 12; vital virtues for 52 morally excellent person, idea of 58

moral reasoning: development of 58;

Kohlberg's model of 57; sequential

stages of 58 ; skills 85 ; styles of 12

moral teaching, in Christianity xiv;

Aquinas, Thomas 61; Catholic 11;

Church's 60

Mosaic Law 26

motivation, need for 143

Mueller, Anselm 37

mutual humanization 100

National Catholic Educational Association (NCEA) 68

'natural habit' of knowing, principle of 127

naturalistic psychology 65

natural law xiii, xv, 4, 13, 16, 20, 28, 49-50, 115, 155-156

natural virtues, types of 52, 76, 118, 142, 146, 148-153

neighbour, Christian idea of 121

neo-Aristotelianism: approach to character development xi; educational philosophy 90

Neo-Thomism 63-64, 66, 67

Newman, John Henry, St. 140

New Testament 30, 34, 48, 84, 127;

moral teaching contained in 27 ;

teachings of Jesus in 26; virtues in 28

New York University 71

nominalism, philosophy of 10

non-Catholic universities 72

non-Christian virtue 52

'non-fragile' happiness 39

non-religious Americans 121

Northrop, F. S. C. 71

Old Testament 4, 28, 48, 84

pagan virtues, idea of 34,48

Paideia Proposal: An Educational Manifesto (1982) 96

pais-agogas (child-tenders) 98

papal encyclicals 65

Papal Teachings: Education (1960) 65

Papal Thomism 65

paradox of moral education 58

Passion of Christ 145

Paul, St. 27, 120, 127-128

penance, sacrament of 10

people of faith 14 
people's character formation, as Christian disciples 10

performance virtues $88,96,123,124-126$ personal development programme 24

personal dignity and status, restoration of 120

personal well-being 29

person of character 39, 119, 134, 144

philosophical anthropology 42, 139

phronesis (practical wisdom) xiv, 37, 126-127, 146, 154; meta-virtue of 40; as subordinate to grace 110

piety, virtue of 149

Pinckaers, Servais 13, 27, 44, 59-61

Pius XI, Pope 63, 70, 107

Plato 30, 32-33, 35; ethical framework for the virtuous life 32; Republic 37, 84

Platonism, ethical thinking on 30

Porter, Jean 31-32

practical wisdom $31,37-39,61,88,90$, 124, 126-128, 131, 135, 146-147, 158 praxis, idea of 100

pre-Christian pagan 96

pre-conciliar manuals, theology of 75

preparatio evangelica 29

Programme of Study 89-95

progressive traditionalism 73

proportionalism, theory of $\mathrm{xv}, 15-21$

proportional morality 16

proportionate reason 16

Protestant ethicists 4

prudence, idea of 118, 148

prudentia (prudence) 127

pseudo-Thomist counter revolution 71

public education/schools 10, 23, 68, 70

public moral life, renewal of 19

purity, ethics of 26

radical Catholicism 100

radical individualism 59

Ramsey Secondary School 97

'rational' moral agent, idea of xiv

rational morality, idea of 8

rational understanding, development of 62

reasoning: process of 56; skills, teaching of 85,129

Redden, John 70, 72

Reformation 10, 84, 113

religious beliefs $1,5,32,104$

religious education 9, 68-69, 73-74, 76, 78; courses in Catholic institutions 63; in schools 66; Thomist principles on 71 religious worship 89

Renaissance 84

Revista Neo-Scholastica 66

Roman Catholic Church 121

Roman Catholic Diocese of Leeds 97

Roman Empire 30

Rugg, Harold 71

Russell, Bertrand 5, 36

Rutkowski, Ronald 69

Ryan, Francis 70

sacramental realism 145

Sacred Congregation of the Council see Congregation for the Clergy

salubritas (wholesomeness) 84

sapientia, notion of 127

schools/school: of character 144-146;

Christian school 98, 104; community

59, 87, 106, 132, 136, 144; environ-

ment, quality of 101; life, virtues in 95,

136; pastoral programme 91

Schools Curriculum Foundation

Document of the Diocese of

Marquette (2014) 134

Screwtape Letters 122

scripture and character, in Christianity

26-28, 47-48; centrality of 34;

Christian teachings 54 ; divine

revelation in 51; legacy of 30

Second Vatican Council (1962) 64, 74-75, 158; Catholic philosophy of education 108; Declaration on Christian Education 107

secular modernity 64

self-activity $67,69,100$

self-controlled individual 103

self-corrective practices 7

self-deliberation 105

self-denial and sacrifice, Christian ethics of 29

self-determination 58, 69

self-development 41, 114

self-direction, process of 58

self-esteem 95

self-examination 93, 132

self-governed learning 135

self-improvement, notion of 29,40

self-mastery, concept of 29, 40, 55

self-sufficiency, notion of 40

sense of being, development of 139

'servile' fear 149

sex trafficking 9 
social construction 9,138

social ethics $13,18-19$

social justice xi, 10, 74, 99, 142

social sciences $3,12,64,78$

social teaching 71,158

sophia $28-29,127$

spiritual and material, unity of xii

spiritual development, secular educational ideal of 89

spiritual life, of Christians 13, 27, 147

spiritual virtues 89

St. Augustine of Hippo 32

Stoicism, ethical thinking on 30

students: moral growth of 99, 103;

relation with teachers 116; self-activity, importance of 100

substance abuse 93

successful living, qualities of xii

Summa Theologiae 11, 31, 34, 47, 65

supernatural destiny 8,42

supernatural virtues 142, 149-150, 152

Taylor, A. E. 66

Taylor, Charles 8

teachers: of character 143-144;

relationship with student 116; training colleges, in UK 65

teaching: religion, methods of 72 ;

Thomas's understanding of 101

teleology: idea of $x v, 1,25,41,72,100$, 127 ; movement 128

telic 152

telos xiii, 5, 36-37, 41, 49, 52, 97, 100, 110, 115, 142; in Aristotelian thinking 37; of Christian education 28; of a human being 25, 35, 104; idea of 99

temperance, notion of $30-31,34,37$, 118,148

theological ethics 7, 11, 13

theological virtues $\mathrm{xv}, 18,29-30,44$, 51-52, 83-84, 98, 108, 118, 121, 135, 145, 148-152

Theology and Education 63

thinking, fallacies of: egocentrism 86; ethical disengagement 86; invulnerability 86; omnipotence 86 ; omniscience 86 ; unrealistic optimism 86

ThirdWorld 121

Thomism in education 61; in AngloSaxon countries 66; Catholic higher education institutions 65; Churchapproved orthodoxy 64; concept of 74; historical survey of 62-66; interpretation of 62; justification for 63 ; non-Catholic perceptions of 71 ; non-Catholic universities 72; philosophy of 62 ; in public schools 70 ; religious education courses 63; revival of 63; Second Vatican Council (1962) 64; secularisation of the college curriculum 65; social teaching 71 ; teacher training colleges 65 ; in twentieth century 66-78

truthfulness, virtue of 93, 105

ultimate reality, concept of 8,29 unbelief, presumption of 8-11 understanding, virtue of 149

University of Chicago 71

utilitarianism, rise of 84

vague generalities 142

Van Doren, Mark 70

Vanier, Jean 40

verbal reasoning 150

Veritatis Splendor (1993) 11-12, 16, 58, 74, 107

virtue education: Catholic understandings of 6,140 ; in practice 129-136; teaching of 134

virtue ethics $\mathrm{xv}, 1,18,20,32,35,41$, 109, 115, 154; Aristotelian concept of 132; Aristotelian-Thomist 5; Christian factor in 17, 155; common-sense 95; moral theory 99; restoration of 64 virtue knowledge 92-94, 148 virtue literacy 87 ; components of 94 ; Jubilee Centre's 97; of students 89, 94 virtues: Augustine's definition of 33; cardinal 84; in Catholic moral theology 64; Christian approach to 98; Christian ideas of 25 ; civic 87,124 ; cultivation of 90; of faith 40; formation of human beings in 33 ; in formation of moral character 123 ; framework of 88-89; goal of 50-53; groupings of 88 ;

historical and social dimension of 108; as inner ethical quality 85; intellectual 87 ; of justice and charity 108; of love of neighbour 40; meta-virtue of phronesis 40; moral 87; natural 148; non-Christian 52; opportunities for children to exercise 94 ; pagan 34; pedagogy 100; perfection of 39; performance 88, 124-126; phronesis- 
guided 37, 40; practice of a life of 34 , 92-94; reasoning 92-94; in school life 136; signalling 84; spiritual quality 33 ; supernatural 149-150; of truthfulness 93; types of 87; see also character virtues

Virtues Project 84, 97

virtuous actions: habits of 85 ; human capacity for 53, 93, 101-102, 105, 136 virtuous habits 51

virtuous life: God's grace and 33-34; Plato's ethical framework for 32 virtuous person 54, 103, 108, 133, 145 , 147-148, 152, 156; Aristotle's vision of 29 ; conscious acts of will 39; meaning of 36

voluntarism, theology of 10
Weil, Simone 127

Western modernity, culture of 100

Western pluralist culture 108

'who am I?', notion of 6,139

wholeness, notion of 43, 47

William of Ockham 10

will of God 4

wisdom, virtue of 149

Wright, Tom 28, 36

wrongdoing and injustice, idea of 110

Yeading Primary School 97

Yearbook of the National Society for the Study of Education 72

Zybura, John 71 


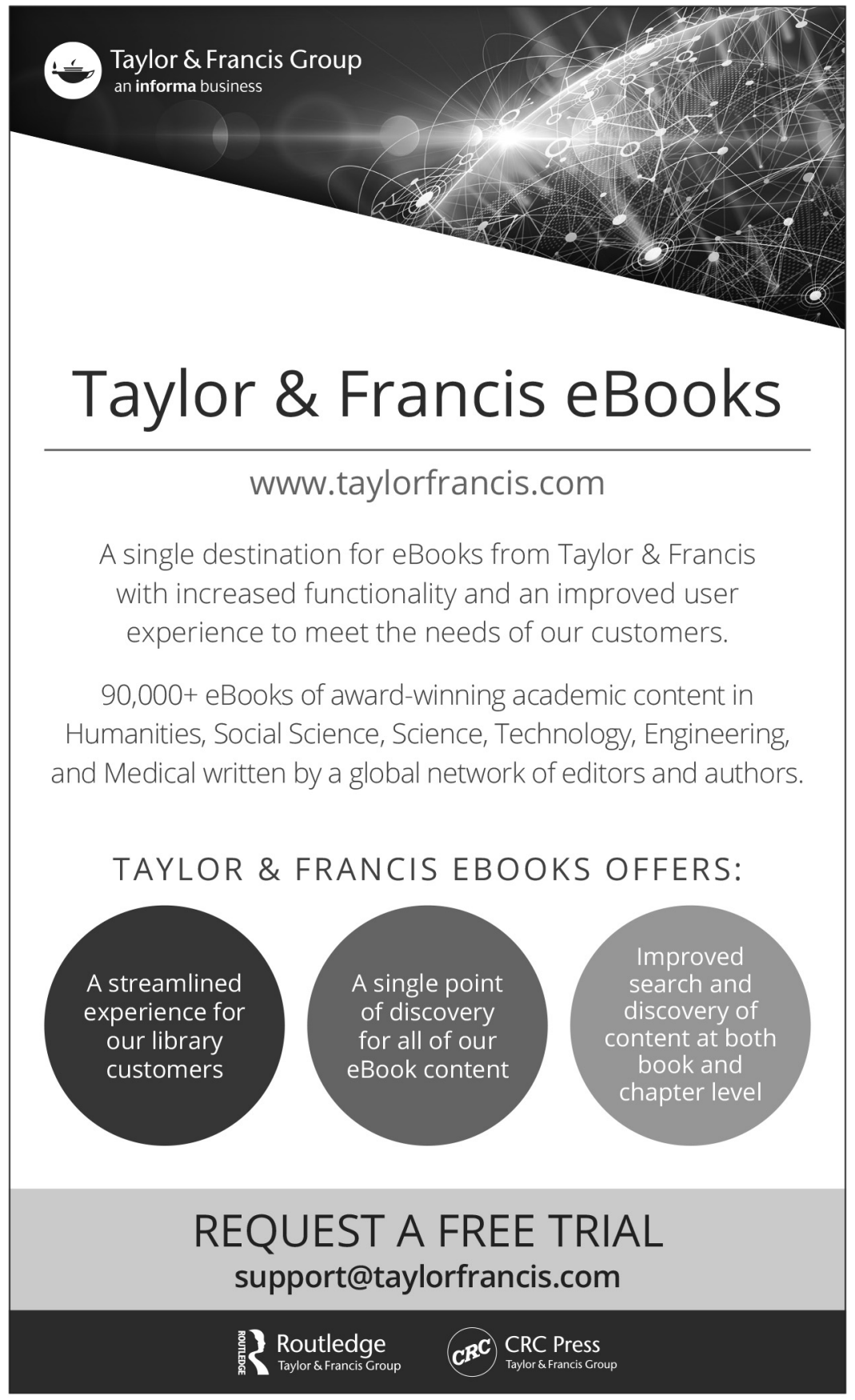

